\title{
METAPHOR AND LITERALISM \\ IN BUDDHISM
}

The notion of nirvana originally used the image of extinguishing a fire. Although the attainment of nirvana, ultimate liberation, is the focus of the Buddha's teaching, its interpretation has been a constant problem to Buddhist exegetes, and has changed in different historical and doctrinal contexts. The concept is so central that changes in its understanding have necessarily involved much larger shifts in doctrine.

This book studies the doctrinal development of the Pali nirvana and subsequent tradition and compares it with the Chinese agama and its traditional interpretation. It clarifies early doctrinal developments of nirvana and traces the word and related terms back to their original metaphorical contexts. Thereby, it elucidates diverse interpretations and doctrinal and philosophical developments in the abhidharma exegeses and treatises of Southern and Northern Buddhist schools. Finally, the book examines which school, if any, kept the original meaning and reference of nirvana.

Soonil Hwang is Assistant Professor in the Department of Indian Philosophy at Dongguk University, Seoul. His research interests are focused upon early Indian Buddhism, Buddhist Philosophy and Sectarian Buddhism. 


\title{
ROUTLEDGE CRITICAL STUDIES IN BUDDHISM
}

\author{
General Editors: \\ Charles S. Prebish and Damien Keown
}

Routledge Critical Studies in Buddhism is a comprehensive study of the Buddhist tradition. The series explores this complex and extensive tradition from a variety of perspectives, using a range of different methodologies.

The series is diverse in its focus, including historical studies, textual translations and commentaries, sociological investigations, bibliographic studies, and considerations of religious practice as an expression of Buddhism's integral religiosity. It also presents materials on modern intellectual historical studies, including the role of Buddhist thought and scholarship in a contemporary, critical context and in the light of current social issues. The series is expansive and imaginative in scope, spanning more than two and a half millennia of Buddhist history. It is receptive to all research works that inform and advance our knowledge and understanding of the Buddhist tradition.

\section{A SURVEY OF VINAYA LITERATURE \\ Charles S. Prebish}

\section{THE REFLEXIVE NATURE OF AWARENESS \\ Paul Williams}

$$
\begin{gathered}
\text { ALTRUISM AND REALITY } \\
\text { Paul Williams }
\end{gathered}
$$

\section{BUDDHISM AND HUMAN RIGHTS}

Edited by Damien Keown, Charles Prebish and Wayne Husted

WOMEN IN THE FOOTSTEPS OF THE BUDDHA

Kathryn R. Blackstone

THE RESONANCE OF EMPTINESS Gay Watson

AMERICAN BUDDHISM

Edited by Duncan Ryuken Williams and Christopher Queen

IMAGING WISDOM

Jacob N. Kinnard
PAIN AND ITS ENDING

Carol S. Anderson

EMPTINESS APPRAISED

David F. Burton

THE SOUND OF LIBERATING TRUTH

Edited by Sallie B. King and Paul O. Ingram

BUDDHIST THEOLOGY

Edited by Roger R. Jackson and John J. Makransky

THE GLORIOUS DEEDS OF PURNA

Joel Tatelman

EARLY BUDDHISM - A NEW

APPROACH

Sue Hamilton

CONTEMPORARY BUDDHIST ETHICS

Edited by Damien Keown

INNOVATIVE BUDDHIST WOMEN

Edited by Karma Lekshe Tsomo 
TEACHING BUDDHISM

IN THE WEST

Edited by V. S. Hori, R. P. Hayes

and J. M. Shields

EMPTY VISION

David L. McMahan

SELF, REALITY AND REASON IN TIBETAN PHILOSOPHY

Thupten Jinpa

IN DEFENSE OF DHARMA

Tessa J. Bartholomeusz

BUDDHIST PHENOMENOLOGY

Dan Lusthaus

RELIGIOUS MOTIVATION AND

THE ORIGINS OF BUDDHISM

Torkel Brekke

DEVELOPMENTS IN

AUSTRALIAN BUDDHISM

Michelle Spuler

ZEN WAR STORIES

Brian Victoria

THE BUDDHIST UNCONSCIOUS William S. Waldron

INDIAN BUDDHIST THEORIES OF PERSONS

James Duerlinger

ACTION DHARMA

Edited by Christopher Queen,

Charles Prebish and Damien Keown

TIBETAN AND ZEN BUDDHISM IN BRITAIN

David N. Kay

THE CONCEPT OF THE BUDDHA Guang Xing

THE PHILOSOPHY OF DESIRE IN THE BUDDHIST PALI CANON David Webster

THE NOTION OF DITTHI IN THERAVADA BUDDHISM

Paul Fuller
THE BUDDHIST THEORY OF SELF-COGNITION Zhihua Yao

MORAL THEORY IN

SANTIDEVA'S SIKSASAMUCCAYA

Barbra R. Clayton

BUDDHIST STUDIES FROM

INDIA TO AMERICA

Edited by Damien Keown

DISCOURSE AND IDEOLOGY IN

MEDIEVAL JAPANESE

BUDDHISM

Edited by Richard K. Payne and

Taigen Dan Leighton

BUDDHIST THOUGHT AND

APPLIED PSYCHOLOGICAL

RESEARCH

Edited by D. K. Nauriyal,

Michael S. Drummond and Y. B. Lal

BUDDHISM IN CANADA

Edited by Bruce Matthews

BUDDHISM, CONFLICT AND

VIOLENCE IN MODERN

SRI LANKA

Edited by Mahinda Deegalle

THERAVĀDA BUDDHISM AND

THE BRITISH ENCOUNTER Elizabeth Harris

BEYOND ENLIGHTENMENT

Richard Cohen

BUDDHISM IN THE PUBLIC SPHERE

Peter D. Hershock

BRITISH BUDDHISM

Robert Bluck

BUDDHIST NUNS IN TAIWAN

AND SRI LANKA

Wei-Yi Chang 
The following titles are published in association with the Oxford Centre for Buddhist Studies

\title{
Oxford Centre for Buddhist Studies \\ a project of The Society for the Wider Understanding of the Buddhist Tradition
}

The Oxford Centre for Buddhist Studies conducts and promotes rigorous teaching and research into all forms of the Buddhist tradition.

\section{EARLY BUDDHIST METAPHYSICS \\ Noa Ronkin}

\author{
MIPHAM'S DIALECTICS AND THE DEBATES ON EMPTINESS \\ Karma Phuntsho \\ HOW BUDDHISM BEGAN \\ Richard F. Gombrich \\ BUDDHIST MEDITATION \\ Sarah Shaw
}

REMAKING BUDDHISM FOR MEDIEVAL NEPAL

Will Tuladhar-Douglas

METAPHOR AND LITERALISM IN BUDDHISM

Soonil Hwang 


\section{METAPHOR AND LITERALISM IN BUDDHISM}

The doctrinal history of nirvana

Soonil Hwang

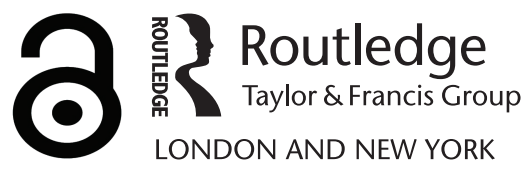


First published 2006

by Routledge

Published 2017 by Routledge

2 Park Square, Milton Park, Abingdon, Oxon OX14 4RN

711 Third Avenue, New York, NY 10017, USA

Routledge is an imprint of the Taylor \& Francis Group, an informa business

Copyright (C) 2006 Soonil Hwang

Typeset in Times New Roman by

Graphicraft Limited, Hong Kong

The Open Access version of this book, available at www.tandfebooks.com, has been made available under a Creative Commons Attribution-Non

Commercial-No Derivatives 4.0 license.

British Library Cataloguing in Publication Data

A catalogue record for this book is available from the British Library

Library of Congress Cataloging in Publication Data Hwang, Soonil, 1968-

Metaphor and literalism in Buddhism : the doctrinal history of nirvana / Hwang, Soonil.

p. cm. - (Routledge critical studies in Buddhism)

Includes translations from Pali, Sanskrit, and Chinese.

'Oxford Centre for Buddhist Studies.'

Includes bibliographical references and index.

1. Nirvana. 2. Buddhism-Doctrines-History.

I. Oxford Centre for Buddhist Studies.

II. Title.

III. Series.

BQ4263.H83 2006

$294.3^{\prime} 423-\mathrm{dc} 20$

2005036655

ISBN13: 978-0-415-35550-6 (hbk) 
FOR DONGJE

MY ABSOLUTELY ADORABLE DAUGHTER 



\section{CONTENTS}

List of figures and tables

Preface

List of abbreviations

Introduction

PART 1

The doctrinal development of nirvana in early Indian Buddhism

1 Nirvana and its reference

2 The two nirvana theory in the early canon

3 Developments of the two nirvana theory 36

4 Nirvana in the Theravāda Buddhist tradition 50

5 Nirvana in Northern Buddhist schools 77

6 Conclusion 106

PART 2

Annotated translations of the related texts in Pali, Sanskrit and Chinese

Selected sources for the nirvana concept and the two nirvana theory

Bibliography 153

Index 


\section{FIGURES AND TABLES}

\section{Figures}

2.1 Potter's wheel

2.2 Either non-returner or arahant

\section{Tables}

2.1 Five aggregates and cognitive process

2.2 Four and seven noble persons

2.3 Ten fetters

3.1 Relative chronology of Chinese abhidharma texts

3.2 The sequence of emerging from nirvana with a remainder of clinging

4.1 Five skandha, twelve āyatana and eighteen dhätu

5.1 Rebirth process between the Sarvāstivāda-Vaibhāṣikas and the Sautrāntikas

5.2 Kleśa and anuśaya from the Sautrāntika viewpoint 92

$\begin{array}{ll}\text { 5.3 Eight characteristics arising with a conditioned dharma } & 102\end{array}$

5.4 Summary of the doctrinal development of nirvana 


\section{PREFACE}

I am glad to be able to thank all those who have helped me to complete this book. It was written originally as a DPhil thesis in Mansfield College, Oxford. I have been using various libraries under the university; in particular, I would like to mention Chinese Studies library, a cosy little library in Walton Street, where I spent most of my time to produce this thesis. White Lotus Foundation (Korea) kindly gave me a scholarship award to support me financially to complete my research. The UK government also granted me a British Korean Scholarship award during the financial crisis in South Korea to continue my work in Oxford.

My debts to academics are many. Professor Richard Gombrich, my DPhil supervisor, helped me enormously to carry out my research. I don't think I could have completed this work without his constant advice and generous encouragement. Professor Tim Barrett, Professor Johannes Bronkhorst, L. S. Cousins, the president of the Pali Text Society, and Dr Andrew Skilton have given valuable criticism, guidance and stimulation for this work. During the final preparation of this book, Professor Peter Harvey and Professor Rod Bucknell gave important comments and fresh perspectives on some matters. I also want to express my gratitude to Professor Damien Keown and Professor Robert Sharf for their kind encouragement.

I want to take this opportunity to express my gratitude to professors and colleagues in the Department of Indian Philosophy in Dongguk University (Korea), in particular Professor Seo Seungwon (Ven. Beopgyong), my MA supervisor, who initially led me into the world of early Indian Buddhism, and Miss Kim Bori who has kindly proofread all my notes in finalizing this book.

During my days in Oxford I enjoyed the privilege of being a member of the Oxford Korea Society and was elected as the president of OKS in 1999. I want to express thanks to all members of OKS, especially the committee members at that time who helped me greatly to carry on my task; to three Korean Buddist monks, Ven. Hojin, Ven. Misan (Wandoo Kim) and Ven. Chong-dok, for their kindness and help; and to Sir Christopher and Lady Ball who allowed me to stay at their delightful flat in Walton Lane where my wife and I had the great joy of having a baby after six years of marriage. 
Finally, my deepest gratitude goes to my parents, who have supported me financially as well as spiritually for almost 15 years since my entrance of Dongguk University and to my wife, Jang Youngok, who has helped me enormously without any complaint whatsoever and gave birth to our adorable daughter, Hwang Dongje.

Seoul 


\section{ABBREVIATIONS}

The abbreviations for Pali texts mainly follow the conventions used in A Critical Pāli Dictionary.

Abhidh-s Abhidhammatthasangaha.

Akb-d Abhidharmakośabhāṣya, ed. Swami Dwarikadas Shastri.

Akb-h Abhidharmakośabhāṣya, ed. Pradhan, A. Haldar.

Akb-p Abhidharmakośabhāṣya, ed. Pradhan.

Akb-pm Abhidharmakośabhāṣya (in Chinese), tr. Paramārtha.

Akb-x Abhidharmakośabhāṣya (in Chinese), tr. Xuanzang.

AN Añguttara-nikāya.

As Atthasālinī.

BAU Bṛadāranyaka Upanișad.

BD Buddhist Dictionary, revised and enlarged by Nyanaponika, Kandy, 1980.

BEFEO Bulletin de l'École Française d'Extrême Orient.

BSOAS Bulletin of the School of Oriental and African Studies, London.

BUCD The Buddhist Scriptures Information Retrieval 4.0 (Budsir IV on CD-ROM), Mahidol University Computing Center, Bangkok, 1994.

CETSCD Chinese Electronic Tripitaka Series, Taisho Tripitaka Volumes 1-32, Chinese Buddhist Electronic Text Association, 1999.

CHU Chāndogya Upanișad.

CPD Critical Pāli Dictionary, Copenhagan, 1924.

CSCD Chațtha Sangāyana CD-ROM, Vipassana Research Institute, Igatpuri, 1997.

Cul Cullaniddesa.

DA Dìrgha-āgama (in Chinese).

DBT Dictionary of Buddhist terms (佛教語大辭典), Nakamura Hajime, Tokyo, 1981.

Dhātuk Dhātukathā.

Dhp Dhammapada.

Dhp-a Dhammapada-ațhakathā. 


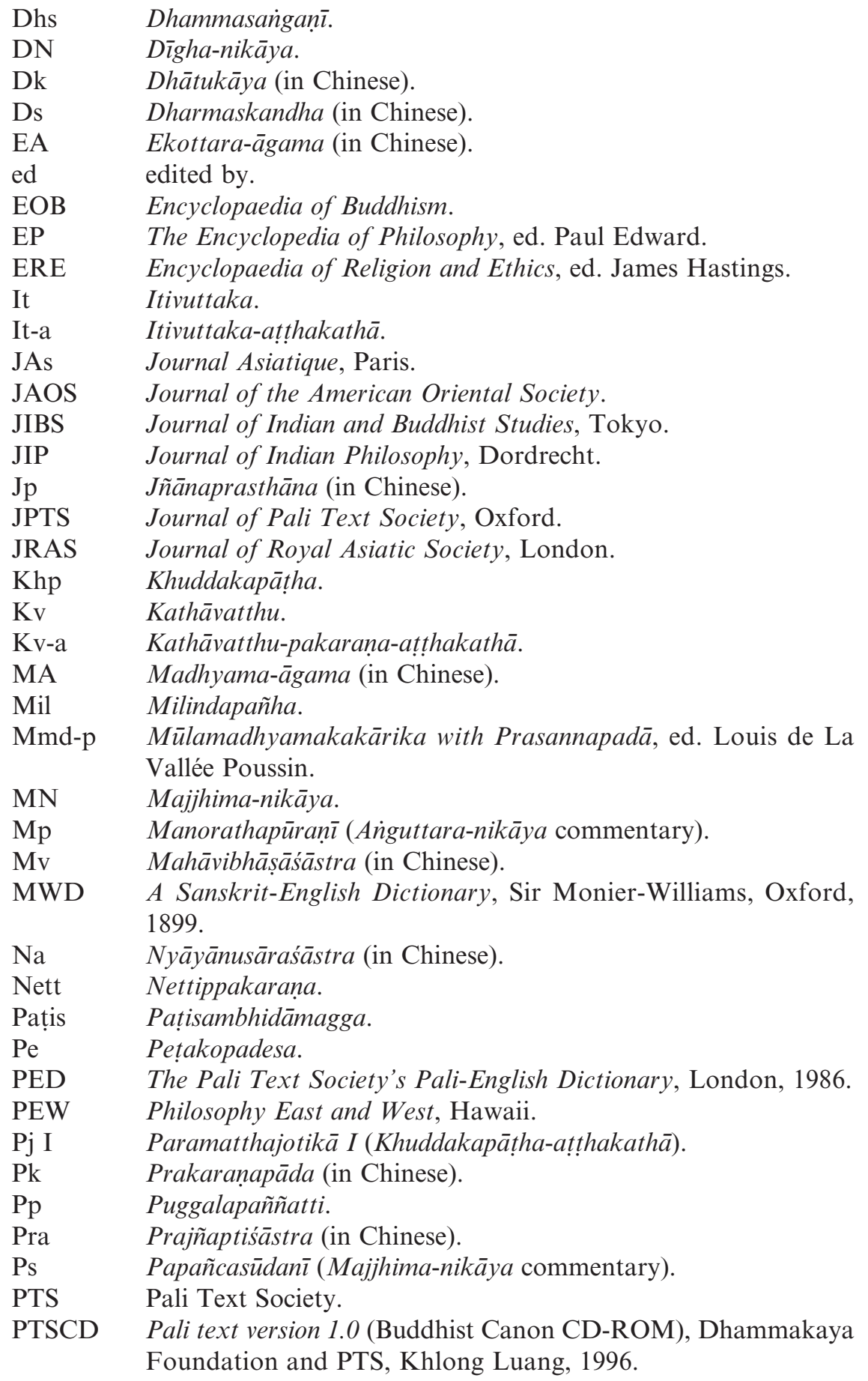


RV Rgveda.

SA Samyukta-āgama (in Chinese).

Sa-d Sphutāarthā Abhidharmakośavyākhyā, ed. Swami Dwarikadas Shastri.

Sa-w Sphuțārthā Abhidharmakośavyākhyā, ed. U. Wogihara.

Sap Samgìtiparyāya (in Chinese).

SB Śatapatha-brāhmana.

Sdp Saddhammapajjotikā (Cullaniddesa commentary).

Sk Sanskrit.

SLTP Sri Lanka Tripitaka Project, the electronic version of the Pali Canon, available from http://jbe.gold.ac.uk/palicanon.html.

SN Samyutta-nikāya.

Sn Suttanipāta.

Sn-a Suttanipāta-ațhakathā.

Sp Samantapāsādikā (Vinayapițaka commentary).

Spk Sāratthappakāsin̄̄ (Samyutta-nikāya commentary).

Sv Sumañgalavilāsin̄̄ (Dīgha-nikāya commentary).

SU Śvetāśvatara Upaniṣad.

TD Taisho shinshu daizokyo (The Tripitaka in Chinese), ed. J. Takakusu and K. Watanabe, The Taisho shinshu daizokyo Kanko Kai, Toyko, 1924-32.

TK Tripitaka Koreana (The Tripitaka in Chinese preserved in Korea) The Research Institute of Tripitaka Koreana, available from www.sutra.re.kr

Th Thera-gāthā.

Th-a Thera-gāthā-atthakathā.

Thī Therīgāthā.

Thī-a Therīgāthā-ațhakathā.

tr translated by.

Ud Udāna.

Vibh Vibhanga.

Vibh-a Sammohavinodanī (Vibhanga commentary).

Vin Vinayapitaka.

Vism Visuddhimagga.

Vk Vijñānakāya (in Chinese).

Vol Volume.

Vs-c Commentary on the Vijñāptimātrasiddhiśāstra (成唯識論述記, Cheng-you-shi-lun Shu-ji, in Chinese).

Yam Yamaka. 



\section{INTRODUCTION}

In the Abhidharmakośabhäsya, the exposition offered by the early canon is often described as contingent (ābhiprāyika), ${ }^{1}$ in contrast to the definitive (lākșanika) exposition of the abhidharma.

One of the problems concerning the truth of the origin of the suffering, the second noble truth, is, as asked in the Mahāvibhāsạsasasstra, 'All the impure dharmas can be the cause and thus the truth of the origin. Why then does the Blessed one say that only thirst ( $\operatorname{trs} n \bar{a})$ is the truth of the origin and not others?'2 In some sūtras it is only thirst $(\operatorname{tr} s \underline{n} \bar{a}),{ }^{3}$ while in some other sūtras it is action (karma), desire (trṣna $)$ and ignorance (avidya $).{ }^{4}$ Although we do not need to go through all thirty answers put forward by the SarvāstivādaVaibhāșikas in the Mahāvibhāṣāsāastra, we have to realise that the discrepancies among scattered quotations from the early canon (sütras) became a serious problem for the masters of the abhidharma, especially when they wanted to define a certain concept, like the second noble truth. One of the answers to the above question given by Vasubandhu in the sixth chapter of the Abhidharmakośabhāsya was as follows: 'Because the elucidation is contingent (äbhiprāyika) in the sütras, yet definitive (lākșanika) in the abhidharma. ${ }^{5}$ 'Contingent' (äbhiprāyika), derived from abhiprê (to approach), seems to mean 'dependent on context' and, thus, means that the exposition of sutras depends largely on taking words in their context, in contrast to the definition-based explanation of the abhidharma ${ }^{6}$ That is to say, Vasubandhu tends to stick to the definitional explanation of the abhidharma, while also trying to find a reasonable explanation by considering the contextual nature of the sütras. ${ }^{7}$ The situation in the Pali Theravāda tradition is no different. As pointed out by Gombrich in his book How Buddhism Began, the mode of teaching applied in the suttas is often expressed as pariyayena, ad hominem, discursive, applied method, illustrated discourse, figurative language, as against nippariyayena, the abstract, general states of abhidhamma. ${ }^{8}$

If the relatively straightforward explanation of the sütra mentioned above caused problems for the masters of the abhidharma, how problematic it must have been if the sütra used metaphor. Unlike the above case, which still leaves scattered traces, the metaphorical structure could easily have been forgotten 
and leave little trace. Unless its contextual as well as historical features are fully understood, it could be almost impossible to clarify correctly what a certain metaphorical explanation in the sütra meant. Moreover, the attitude of the abhidharmic masters towards the early canon tended to pay 'too much attention to the precise words used and not enough to the speaker's intention, the sprit of the text'.

This unintentional literalism, when coupled with the metaphorical structure of a certain teaching in the sütra, could easily trigger early changes in meaning and then the difference between the two might well lead to a doctrinal development in early Buddhism. The early Buddhist concept of nirvana may be a good example of how delicate it could be when we are dealing with an early Buddhist concept with a metaphorical nature. The whole picture of nirvana could not easily be revealed unless we pay full attention to its contextual and historical features together with its early developments in the abhidharma, as well as its later developments among Buddhist schools.

\section{Aims and scope}

Numerous studies of nirvana have been undertaken since Buddhism began to be studied in the Western world. There even is a book dedicated to the history of the Western interpretations of nirvana ${ }^{10}$ yet it is really hard to find a work devoted entirely to the historical developments of nirvana from the early canon (sütra) to the abhidharma and to the treatises (śästra) in both Northern and Southern traditions.

One of the common mistakes scholars can make is that their general explanation of nirvana may represent the view of their favoured Buddhist school. In other words, their account of the early Buddhist concept of nirvana sometimes represents a view that is held only by a specific Buddhist school.

If the study of nirvana leans to the early canon (sütra), the doctrinal development of nirvana could easily be missed; whereas if the study leans to the abhidharma and the treatises (śästra), the early metaphorical nature of nirvana could easily be ignored. Moreover, the early canon (sütra) was full of diverse terms and metaphors. Without considering the doctrinal and historical context of nirvana, we could easily stick to a partial meaning of a word in a sutra and then regard that as the comprehensive meaning of the word in the entire early canon. Without considering the metaphorical nature of nirvana, we could not come close to the real picture of nirvana at its early stage, and as a consequence we could easily miss critical points in the later exegetical and doctrinal problems concerning nirvana.

When I first read Gombrich's How Buddhism Began, it was, as described by Cousins in his review, ${ }^{11}$ 'very stimulating' and gave me a different view on some problems concerning the Buddhist concept of nirvana. Two questions I had before were: why nirvana during life, or enlightenment, was defined as the cessation of the triple fires of passion, hatred and delusion, ${ }^{12}$ while the way 
to reach it was described as a successive destruction of fetters (samyojana $)^{13}$ or the cessation of all cankers (äsava) ${ }^{14}$ and why the lack of attachment, generally accepted as the reference of the word upādi, or upadhi in Sanskrit within mainstream Buddhist tradition, when used in the context of nirvana during life and nirvana at death, applied equally to nirvana with a remainder of clinging (sa-upādisesanibbānadhātu / sopadhiśeșanirvānadhātu) and nirvana without a remainder of clinging (anupādisesanibbānadhātu / nirlanupadhiśeșanirvāṇadhātu).

The answer to my questions was that I had completely missed nirvana's historical and metaphorical contexts. According to Gombrich, to number three could be to juxtapose the three sacrificial fires of a Brahman householder with the triple fires of passion, hatred and delusion, ${ }^{15}$ while the word upādi or upadhi when used in a metaphorical structure that embraces Enlightenment and its opposite could mean 'fuel' with an underlying reference to the five aggregates. ${ }^{16}$ That is to say, understanding nirvana's historical and metaphorical contexts could reveal surprisingly rich information to solve some of the exegetical and ontological problems concerning nirvana from a different perspective.

The aim of this book is to clarify the early doctrinal history of the nirvana concept and the two nirvana theory, which flourished under the image of a fire extinguished, by tracing the term nirvāna back to its origin in terms of its metaphorical structure, then following its early developments in the Abhidharma by checking its technical uses with its philosophical developments, and elucidating diverse interpretations and doctrinal developments in the exegeses and treatises of the Southern and Northern Buddhist schools by examining which school kept the original references of the nirvana concept and the two nirvana theory expressed in the early metaphorical structure.

The scope of this book ends around the fourth or fifth century CE, when the Visuddhimagga was composed by Buddhaghosa in the Southern tradition, while the Abhidharmakośabhāsya was composed by Vasubandhu and as a response the Nyāyānusāraśāstra was composed by Sanghabhadra in the Northern tradition. From the exegeses and treatises at around this time we can reconstruct the fully developed form of the nirvana concept and the two nirvana theory in three major Indian Buddhist schools: the Theravādins, the Sarvāstivādins and the Sautrāntikas. By examining their views on nirvana, established from their own exegetical and ontological perspectives, we may well determine at the end of the thesis which school was of the original meaning of nirvana, especially through their interpretation of the last stanza of the Anuruddha's famous verse, believed to have been uttered at the time of the Buddha's final release at Kuśinagara.

The Mahāyāna interpretations of the nirvana concept and their equivalent of the two nirvana theory are beyond the scope of this book, owing to their different approaches to early Buddhist materials and different doctrinal perspectives. According to Asanga in his Mahāyannasamgraha, the acceptance 
of apratișthita-nirvāna was one of the ten differences between the Mahāyāna and the traditional Buddhist schools. ${ }^{17}$ According to Louis de La Vallée Poussin, there could be one more, anādikālika-prakrtiśuddha-nirvāna in the Vijñaptimātratāśăsiddhi, so that together there were four nirvanas in the Yogācāra tradition. ${ }^{18}$ Comparing these three or possibly four nirvanas with the traditional two nirvana theory could be interesting, yet in order to do this we would need look at all the relevant Mahāyāna materials from the doctrinal and historical perspective. I want to leave this task for further research, hoping that the current study will become a firm base from which ventures upon the Mahāyāna territory and their equivalent of the two nirvana theory can be Launched.

\section{Outline of the chapters}

In Chapter 1, I deal briefly with the word nirvāna, its etymological meaning and original reference. Despite its established definition, the cessation of the triple fires of passion, hatred and delusion, later Buddhists in both Northern and Southern traditions were searching for other explanations of the word nirvāna. What I show in this chapter is that missing nirvana's historical and metaphorical context at an early stage could be one of the main causes for the later developments of diverse etymological explanations of nirvana seen in the Pali exegesis and Chinese treatises (śāstra).

The main issue dealt with in Chapter 2 is the two nirvana theory. The traditional explanation of the two nirvana theory, nirvana during life and nirvana at death, was challenged by such scholars as Hermann Oldenberg, ${ }^{19}$ A. O. Lovejoy $^{20}$ and Peter Masefield ${ }^{21}$ and by one sütra in the Chinese Ekottaraagama. ${ }^{22}$ In this chapter, I deal with this problem of the two nirvana theory by examining the etymology of upādi in terms of its subjective and objective meanings, the usage of upadisesa within the context of nirvana and the usage of upädisesa within the context of the four noble persons, and by establishing the differences between the non-returner and the two nirvana elements.

The early canon in both Pali and Chinese traditions is the main material in this chapter. With the help of a computer-aided search of three CD$\mathrm{ROMs}^{23}$ and the electronic version of the Pali canon on the web ${ }^{24}$ for the Southern tradition, and one CD-ROM ${ }^{25}$ for the Northern tradition, finding words and clauses related to nirvana is nowadays far easier and more convenient. Although I used these electronic materials for the Pali canon to retrieve data, my main source is the PTS editions. I also use the Chinese Agamas to compare corresponding passages in the Pali Nikâyas.

Chapter 3 deals with the development of the nirvana concept in both the Pali abhidhamma tradition, and the Chinese abhidharma tradition, and then examines how this development affects the two nirvana theory in the Jñannaprasthāna and in the Theravāda exegetical traditions. I also trace Buddhaghosa's seemingly Northern Buddhist originated explanation of the 
two nirvana theory in the Visuddhimagga back to the Nettippakarana and the Petakopadesa in the Southern tradition.

Chapter 4 is mainly about the state of the Tathägata after death, especially against the claim of such scholars as F. Otto Schrader ${ }^{26}$ and Peter Harvey ${ }^{27}$ that the allegedly common Indian view was already presupposed in the early canon when the metaphor of a fire extinguished ${ }^{28}$ was used to explain what happens to an enlightened person after death. In this chapter, I deal with this problem by examining Buddhist methodology seen in the early canon by the name of yoniso manasikāra, by clarifying the meaning of the metaphor of a fire extinguished in the context of Vacchagotta's unanswered questions and by exploring later developments in the Therāvada tradition seen in the Sammohavinodan̄ (Vibhanga commentary), the Theragāthā-atthakathā and the Visuddhimagga. I also discuss the Therāvadin's unique argument, the 'singularity' of the unconditioned (asamskrta) that is nirvana, and its implications, under the influence of the Buddhist theory of momentariness.

Chapter 5 is devoted to the doctrinal development of the nirvana concept and the two nirvana theory in Northern Buddhist schools. It explores the later development of the two nirvana theory seen in the Mahāvibhāṣāśăstra, reconstructs the Sautrāntika concept of nirvana in the Abhidharmakośabhāsya and deals with ontological issues surrounding Anuruddha's simile seen in the Abhidharmakośabhāssya and the Nyāyānusāraśästra. Although the Abhidharmakośabhāṣya presents both the Sarvāstivādin and the Sautrāntika opinion, its comment is mainly in favour of the Sautrāntika point of view. Thus the orthodox Sarvāstivādin's position should be considered and defended from Sangghabhadra's Nyāyānnusāraśästra. For the two Chinese treatises, the Mahāvibhāṣāśästra and the Nyāyānusāraśästra, Louis de La Vallée Poussin did indispensable work: he selected the passages related to nirvana in those two and the Abhidharmakośabhassya and translated them into French. My translation of these texts depends largely on his works. 



\section{Part 1}

\section{THE DOCTRINAL DEVELOPMENT OF NIRVANA \\ IN EARLY INDIAN \\ BUDDHISM}





\section{1 \\ NIRVANA AND ITS REFERENCE}

Since Buddhism began to be studied in the Western world, numerous studies of nirvana have been undertaken, yet no fully satisfactory clarification of it has been made. This is not surprising if we consider the fact that while for Buddhists it is to reach nirvana, it is for scholars to study what nirvana may be. That is to say, nirvana for Buddhists has always been their highest goal, which can be reached through morality, meditation and wisdom, whereas for scholars it has been a kind of state that can be, though with difficulty, defined and explained in human language. 'A very different thing' was the early verdict given by Louis de La Vallée Poussin in the Encyclopedia of Religion and Ethics. ${ }^{1}$

A good starting point to explore the word nirvanna could be from its etymology. Though there can be other opinions, such as T. W. Rhys Davids's suggestion in his PED, ${ }^{2}$ Western scholars tend to agree on the etymological meaning of nirvana as 'going out': the noun nirvanna $a^{3}$ is derived from the negative prefix nir plus the root $v \bar{a}$ (to blow). Its original meaning seems to be, as Ñyāṇamoḷi suggested, " "extinction" of a fire by ceasing to blow on it with bellows (a smith's fire, for example)'. When a smith stops blowing on a fire, it goes out automatically. In this respect, this word nirvanna should be understood as intransitive: a fire going out due to lack of cause, such as fuel or wind.

If we accept this etymological meaning, which is probably pre-Buddhist, what does the term refer to within the early Buddhist tradition? One of the common misunderstandings of nirvana is to assume that it refers to the extinction of a person or soul. This view may be caused by the words nibbuta and nibbuti, which can be used of the person or soul. However, both words are derived not from nir $\sqrt{ } v \bar{a}$ (to blow) but from nir $\sqrt{ } v r$ (to cover) and their meaning in these cases is, as K. R. Norman suggests, 'satisfied, happy, tranquil, at ease, at rest' for the former and 'happiness, bliss, rest, ceasing' for the latter. Moreover, not only does this view lack any textual evidence, ${ }^{6}$ it is also the mistaken opinion identified in the early canon as annihilationism (ucchedavāda). ${ }^{7}$ 
In the early canon, nirvana was applied to the two most important events in the Buddha's life: enlightenment and final liberation. ${ }^{8}$ The former, technically called 'nirvana with a remainder of clinging (sa-upādisesanibbānadhātu)', is the state in which the triple fires of passion, hatred and delusion are extinguished but the fuel, the five aggregates in a metaphorical structure, still remains; the latter, technically called 'nirvana without remainder of clinging (an-upādisesanibbānadhātu)', is the state in which there is no more fuel left. ${ }^{9}$

E. J. Thomas regarded Jainism as older than Buddhism ${ }^{10}$ and said that it is unlikely that the word nirvana, which has been used in both traditions, was borrowed from the latter. However, we cannot be so certain that Jainism predates Buddhism, because the existence of Jainism before the Jina, or Mahāvīra, has not been demonstrated and most of the Jain texts that survive are apparently later than the early Buddhist canon. The problem of the Jains' use of nirvana is that it always refers, as Hermann Jacobi pointed out, to the final liberation:

liberated souls will be embodied no more; they have accomplished absolute purity; they dwell in the state of perfection at the top of the universe, and have no more to do with worldly affairs; they have reached nirvāna (nivrti, or mukti). ${ }^{11}$

The Jains' notion of nirvana was clearly different from that of early Buddhism. ${ }^{12}$ However, there is a different use of nirvana in the BhagavadGìtā. Although Buddhist influence on the Bhagavad-Gitta is well known, ${ }^{13}$ the use of nirvana here gives a clue to what it refers to in early Buddhism. The following verses in the fifth chapter clearly show that it refers not to the final liberation but to Enlightenment:

Who finds his happiness within, his joy within, and likewise his light only within, that disciplined man to Brahman-nirvāṇa goes, having become Brahman. Brahman-nirvāna is won by the seers whose sins are destroyed, whose doubts are cleft, whose souls are controlled, who delight in the welfare of all beings. To those who have put off desire and wrath, religious men whose minds are controlled, close at hand Brahman-nirvāna comes, to knowers of the self. (5. $24-6) .{ }^{14}$

The compound, 'brahman-nirvāṇa (brahmanirvāṇa)', recalls Buddhism, not only because the word brahman is used in compounds in Buddhist texts, ${ }^{15}$ but also because 'become Brahman (brahmabhüta)' is used in the early canon to describe the Buddha or a saint (arahant) who has already attained enlightenment. ${ }^{16}$ Thus, although this word seems to have been used in Jainism with the meaning of final liberation, it was later, in the Bhagavad-Gìtā, borrowed from Buddhism with the already established meaning of enlightenment. For 
early Buddhists the weight was more on nirvana during life, enlightenment, than nirvana at death, the final liberation. ${ }^{17}$

What this term refers to within the early Buddhist tradition seems to be the extinction of the triple fire of passion, hatred, and delusion. ${ }^{18}$ This is, according to R. F. Gombrich, part of an extended metaphorical structure that embraces enlightenment and its opposite. ${ }^{19}$ From the first part of the Mahävagga in the Vinaya, we could assume that this reference was established at a very early stage of the Buddha's mission. In the sermon known as the aditta-pariyayya, ${ }^{20}$ the Buddha preached to newly converted matted-hair ascetics ( jatila) that our liberation depended on putting out the triple fire of passion, hatred and delusion with which all parts of our cognitive process are on fire. ${ }^{21}$

Numbering the fires as three could have another hidden message: it is, according to Gombrich, 'to allude to a set of three fires which the brahmin householder was committed to keeping alight and tending daily so that they came to symbolise life in the world, life as a family man'. ${ }^{22}$ While the fire image in Brahmanism is good and desirable, this triple fire of passion, hatred and delusion in Buddhism is the one that should be abandoned. In other words, this could make a deep impression on those matted-hair ascetics (jatila) also known as the 'fire cult'. ${ }^{23}$ Not only did the Buddha express his doctrine by using this fire image, he also used it as a riposte to Brahmanism.

This metaphorical reference did not entirely satisfy later Buddhists, since they sought other explanations of the word nirvanna. The problem seems to be that there is a gap between the definition of nirvana applying this reference and the way to reach this highest goal. Although it still was used as a definition of nirvana ${ }^{24}$ and the unconditioned ${ }^{25}$ in the Theravāda tradition, ${ }^{26}$ what they did in practice was trying not only to extinguish the passion, hatred and delusion but also to extinguish all cankers (āsava) or defilements (kilesa).

This situation is not very different in the Northern Buddhist tradition. The Chinese equivalent of the Nibbannasutta in which nirvana was defined as the extinction of the triple fires ${ }^{27}$ seems to have been modified slightly: it defines nirvana as 'The cessation of passion, the cessation of hatred, the cessation of delusion and the cessation of cankers (äsavas). ${ }^{28}$

In later exegetical works, both traditions show a whole new set of etymological definitions of the word nirvana. In the Mahāvibhāșáśăstra, the extinction of the triple fires was devalued in as much as it was just one of nine different etymological definitions of the word:

Question: why is it called nirvana? Answer: As it is the cessation of defilements (kleśanirodha), it is called nirvana. As it is the extinction of the triple fires, it is called nirvana. As it is the tranquillity of three characteristics, it is called nirvana. As there is separation (viyoga) from bad odor (durgandha), it is called nirvana. As there is separation from destinies (gati), it is called nirvana. Vāna means 
forest and nir means escape. As it is the escape from the forest of the aggregates, it is called nirvana. Väna means weaving and nir means negation. As there is no weaving, it is called nirvana. In a way that one with thread can easily be woven while one without that cannot be woven, in that way one with action (karma) and defilements (kleśa) can easily be woven into life and death while an aśaikșa who is without any action and defilements cannot be woven into life and death. That is why it is called nirvana. Vana means new birth and nir means negation. As there is no more new birth, it is called nirvana. Vāna means bondage and nir means separation. As it is separation from bondage, it is called nirvana. Vana means all discomforts of life and death and nir means passing beyond. As it passes beyond all discomforts of life and death, it is called nirvana. ${ }^{29}$

A similar approach can also be found in the Theravāda exegetical tradition. Steven Collins, in his book Nirvana and Other Buddhist Felicities, presents four different etymological definitions. ${ }^{30}$ First of all, the word nibbāna means 'without desire', from the negative prefix nir, with vāna meaning desire derived from $\sqrt{ }$ van (to desire). Thus nirvana was explained in the Sammohavinodani as 'Craving is called desire. Since that does not exist there, it is called withoutdesire. ${ }^{31}$ Second, it means 'state of the renunciation of desire and craving', from nir meaning to abandon or renounce by reference to the root ni-kkham, and vana meaning desire. ${ }^{32}$ Third, the word vanna can mean 'wood' or 'jungle', ${ }^{33}$ which refers to the aggregates (skandha) according to the Mahāvibhāṣassástra seen above. ${ }^{34}$ It could thus mean escape from the aggregates. Finally, it can be elucidated as 'abandoning the desire which weaves together life to life (by means of) action (karma) and its result', ${ }^{35}$ from taking vāna as 'sewing' or 'weaving'.

In fact, Buddhaghosa also ignored the original etymological meaning of the word, the extinction of the triple fires of passion, hatred and delusion, and presented a different explanation of nirvāna based on vāna meaning weaving derived from $\sqrt{ } v \bar{a}$ (to weave) in his Visuddhimagga:

It is called nibbāna (extinction) because it has gone away from (nikkhanta), has escaped from (nissata), is dissociated from, craving, which has acquired in common usage the name 'fastening (vāna)' because, by ensuring successive becoming, craving serves as a joining together, a binding together, a lacing together, of the four kinds of generation, five destinies, seven stations of consciousness and nine abodes of being. ${ }^{36}$

What later Buddhists in both Northern and Southern traditions did seems to be to narrow the gap between the definition of nirvana based on the 
original etymological definition and the developed and systematised opinion of their highest goal, nirvana. Since taking the word vana, or vāna, to refer to 'forest' or 'weaving' was common to both traditions, their search for a new etymology could probably be regarded as a common phenomenon among sectarian Buddhist schools. If we take these diverse definitions derived from a single original source, it probably started before the separation of the Sarvāstivādins and the Vibhajyavādins during the reign of the Emperor Ashoka. By contrast, if we take them as a result of the copying of each other among Buddhist sects, it could be a later sectarian development. In both cases, Buddhist masters in both traditions seem not to have been satisfied with the original etymological definition.

Searching for these new etymologies of nirvana seems to have started at the time when the extinction of the triple fires of passion, hatred and delusion was still used and accepted as the definition of nirvana, while its metaphorical structure had started to be forgotten. Without an understanding of its metaphorical structure, the original definition of nirvana could not satisfy later Buddhists, since it did not cover all aspects of their highest goal. In the next chapter, I discuss two most important aspects of nirvana: nirvana with a remainder of clinging and nirvana without a remainder of clinging. 


\section{THE TWO NIRVANA THEORY IN THE EARLY CANON}

It is generally accepted that there are two nirvanas in early Buddhism and they are differentiated as nirvana with a remainder of clinging and nirvana without a remainder of clinging. There are, however, unsolved problems in their descriptions: not only are they spelt differently, sa-upādisesanibbānadhātu and anupādisesanibbānadhātu in Pali, as against sopadhiśeșanirvānadhātu and nirlan-upadhiśeșanirvāṇadhātu in Buddhist hybrid Sanskrit, ${ }^{1}$ but they also have different meanings according to what the word upādi, or upadhi in Sanskrit, refers to.

The Theravāda exegetical tradition takes upādi to refer to 'the aggregates' and as a consequence the two kinds of nirvana correspond to the two most important events in the Buddha's life: enlightenment and final liberation at death. ${ }^{2}$ The first is expressed as nirvana with a remainder of clinging and is explained as the cessation of defilements (kilesa-parinibbana). That is to say, although defilements, such as passion, hatred and delusion, have completely ceased, the aggregates still remain (saupādisesa). ${ }^{3}$ The second is expressed as 'nirvana without a remainder of clinging' and is explained as the cessation of the aggregates (khandha-parinibbana). ${ }^{4}$ That is to say, these remaining aggregates cease completely. ${ }^{5}$

Figuratively speaking, it is like stopping a potter's wheel. The potter's wheel is spun around by the power of an electric motor. Saupādisesa is like a wheel spinning even after the power is turned off, due to momentum; anupādisesa is like the final stopping of the wheel because there is no more force left.

By contrast, some of the modern interpretations take upādi to refer to 'attachment'. Such scholars as Hermann Oldenberg, ${ }^{6}$ A. O. Lovejoy ${ }^{7}$ and Peter Masefield ${ }^{8}$ insisted that upādi could not originally have meant 'the aggregates', since the early canon gives another usage of upādisesa. Not only is it used in describing the first three of the four noble persons (ariyapuggala), ${ }^{9}$ it is also used in describing a pair with perfect knowledge $(a \tilde{n} \tilde{n} \bar{a}),{ }^{10}$ one of whom is a non-returner (anāgāmin) and the other a saint (arahant). ${ }^{11}$ Thus, the state of a non-returner can be expressed as nirvana with a remainder of clinging, since there still is attachment left (saupädisesa); whereas the state of a saint (arahant) can be expressed as nirvana without a remainder of clinging, 


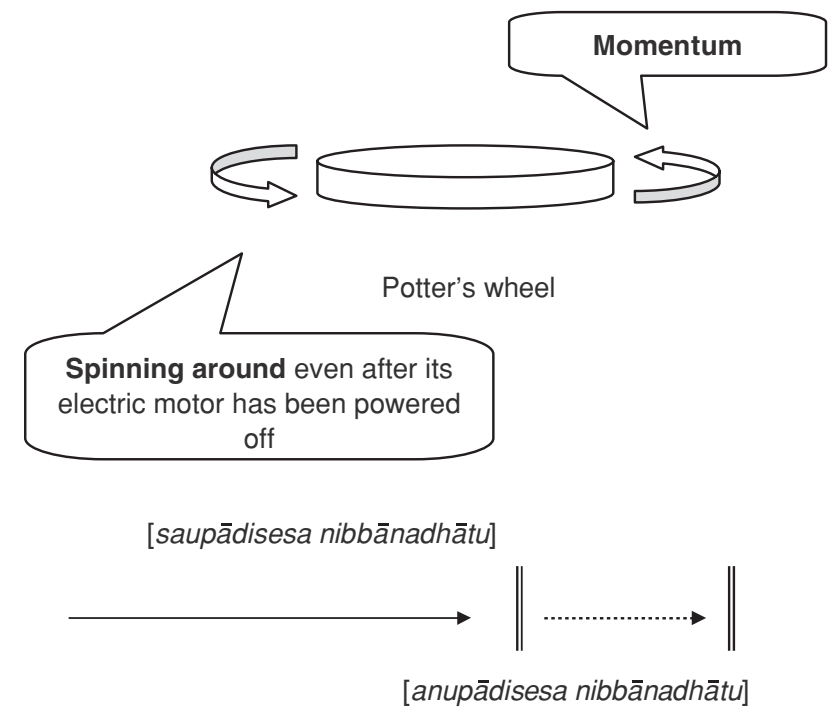

Figure 2.1 Potter's wheel

since there is no more attachment left (anupādisesa). As certain advanced disciples will obtain either one or the other, the two nirvana elements cannot be understood as successive stages, as posited by the Theravāda exegetical tradition, but must be mutually exclusive means by which different disciples attain their liberation. ${ }^{12}$

The crucial argument put forward is, as noted by Huzita Koudazu in The Journal of Indian and Buddhist Studies, that 'there is no clear evidence within the early canon saying upādi to mean the aggregates'. ${ }^{13}$ Louis de La Vallée

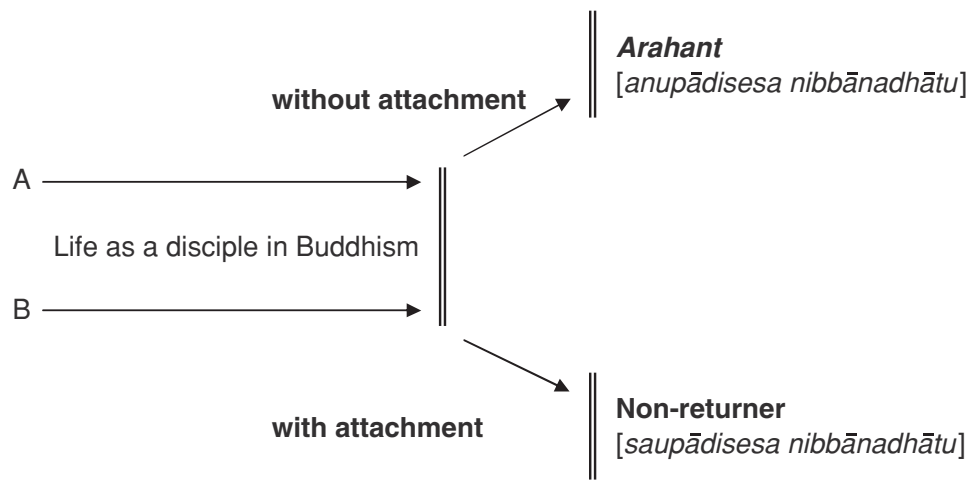

Figure 2.2 Either non-returner or arahant 
Poussin ${ }^{14}$ and E. J. Thomas ${ }^{15}$ seem to have had the view that the use of upādi to refer to the aggregates could not be the oldest usage.

However, such evidence can be found within the early canon, though not directly but indirectly. According to Gombrich, the term upādi means objectively 'fuel', which denotes 'the aggregates' in a metaphorical structure that embraces enlightenment and its opposite. ${ }^{16}$

In this chapter, I deal with this problem of the two nirvana theory by examining the etymology of upādi in terms of its subjective and objective meanings, the usage of upadisesa within the context of nirvana and the usage of upädisesa within the context of the four noble persons, and by establishing the differences between the non-returner and the two nirvana elements.

\section{Etymology of upādi}

The word upādi is usually found compounded with sesa, 'remainder'. Despite its phonetic similarity with upadhi, its synonym is upadanna, which shares the same etymology, deriving from upa $\bar{a} \sqrt{ } d \bar{a}$ (to give). ${ }^{17}$

Upādāna has both objective and subjective meanings. Objectively, it means 'fuel, supply, provision' or, literally, that material substratum by means of which an active process is kept alive or going. ${ }^{18}$ In the Upädänasutta in the Samyuttanikāya, the word upādāna is used in the following way: 'Verily such a great bonfire, so fed, so supplied with fuel, would burn for a long while. ${ }^{19}$ Subjectively, it means 'drawing upon, grasping, holding on, grip, attachment' in the sense that a fire clings to fuel in order to keep burning. Similarly, living beings cling to food, or more precisely nourishment, to keep alive. This word can also be used in terms of the process of rebirth. It is that by means of which the process of rebirth is kept going or alive: that is to say, it is the cause of rebirth.

In the later systematisation, upādāna was used in this subjective sense and was of four kinds: 'Sensuous Clinging ( $k \bar{a} m u p \bar{a} d \bar{a} n a)$, Clinging to Views (dițthupādāna), Clinging to mere Rules and Ritual (sīlabbatupādāna), and clinging to Personality-Belief (atta-vādupādāna) ${ }^{,}{ }^{20}$

This subjective meaning of upa $\bar{d} d i$ is almost synonymous with a meaning of upadhi ${ }^{21}$ that is derived from a different verb: upa $\sqrt{ } d h \bar{a}$ (to put). The literal meaning of upadhi is 'that on which something is laid or rests, basis, foundation, substratum'.$^{22}$ According to PED, it designates in the oldest texts worldly possessions and belongings, such as 'wife and children, flocks and herds, silver and gold'. ${ }^{23}$ We can see this usage of upadhi in the famous dialogue between the Buddha and Māra in the Suttanipāta:

'One with sons rejoices because of (his) sons', said Māra the evil one. 'Similarly the cattle-owner rejoices because of (his) cows. For acquisitions (upadhi) are joy for a man. Whoever is without acquisitions does not rejoice.' 
'One with sons grieves because of (his) sons', said the blessed One. 'Similarly the cattle-owner grieves because of (his) cows. For acquisitions (upadhi) are grief for a man. Whoever is without acquisitions does not grieve. ${ }^{24}$

K. R. Norman regards these two verses as 'a punning exchange of words based upon the two meanings of upadhi':25 'objects which one amasses' and 'the love and affection which one has for such things, which form an attachment and lead one back to rebirth'. While the reference of upadhi, or acquisition, in the first verse is objects themselves, such as sons and cows, the exact meaning in the second is not the objects themselves, but love or affection for such objects.

For example, the images or memories of his beloved cause pain to a man who has been dumped by his lover. He undergoes pain and this pain is not caused directly by the beloved one, but by his subjective affection for her. Once he overcomes his attachment, there is no more pain in him even if the beloved one is still around.

In CPD, this double aspect is explained as follows: ${ }^{26}$ just as kāma means, objectively, the objects of sensual enjoyment and, subjectively, enjoyment of those objects and sense-desire, upadhi thus means, objectively, possessions, belongings, and subjectively the attachment to, affection for, clinging to these possessions. It is thus equated with tanhāa, ādāna, upādāna, āsava, kamma, and in later systematisation particularly with kāmā, khandhā, kilesā, abhisañkhārā, all of which are causes or bases of rebirth.

In the Sammasanasutta in the Samyuttanikayya, upadhi is used in much the same way as upādana in the context of dependent origination. ${ }^{27}$

Where there is upadhi, there comes to be old-age and death (jarämarana); where upadhi is not, old-age and death come not to be. ... Where there is thirst ( $\tanh \bar{a})$, there upadhi comes to be. Where thirst is not, upadhi comes not to be.

In other words, the two words can be used almost synonymously in this subjective sense. What is the relevance of this similarity? I think this could explain the well known problem that upädisesa is the Pali equivalent of upadhiśeșa in Buddhist Sanskrit.

K. R. Norman has said: 'the difference between the two was of course noticed long ago, yet little effort has been made to explain why they are different'. This difference eventually leads him to suggest another etymology, upa adhilati $\sqrt{ }$ sis (to leave), positing that these two phrases must originally have had the same meaning. Thus, the whole term originally consists not of two words meaning 'a remainder of clinging' but of a single word meaning simply 'a remainder'. In fact, the Chinese translation of this word before Hiuan-tsang, who translates this words as $y u$-yi (餘依), 'a remainder of 
clinging', is $y u$ (餘), simply 'a remainder'. However, this etymology is not entirely satisfactory since the word yi (依, upadhi in Skt) is treated as a separate word and commented on individually in the Mahāvibhāsāss $\bar{a} s t r a .^{28}$ That is to say, a master of the abhidharma regarded this upadhiseșa not as one but as a compound of two words.

According to the recent publication of 'Ancient Buddhist Scrolls from Gandhāra' by Richard Salomon, ${ }^{29}$ the Gandhārī nirvana without a remainder of clinging (anupādisesanibbānadhātu) is spelled anuadiśesanivanadhadu. According to Gandhārī phonology anupắdiśeșa like Pali could be the underlying form, but anupẵdhiśeșa like Buddhist Sanskrit could not. ${ }^{30}$ Moreover, $d h$ and $b h$ are often written in the place of $d$ and $b .^{31}$ Thus, this could explain how upādi was replaced by upadhi in Buddhist Sanskrit. However, this is only possible if Buddhist hybrid Sanskrit originally came from Gāndhārī.

I suggest that the similarity between upādi and upadhi in their subjective sense played a part in the replacement of upādi by upadhi. The two words in their subjective sense were already widespread among the wanderers of the Buddha's day. In the Saupādisesasutta in the Anguttaranikāya, the word upädisesa, which should be understood in its subjective sense, is first mentioned not by the blessed one but by the wanderers of other views (aññatitthiyānam paribbājakānam). ${ }^{32}$ The four kinds of upādāna listed and commented on in the Dhammasangaṇi seen above ${ }^{33}$ have a subjective sense, in line with psychological trends in the Pali abhidhamma. Thus, the subjective meaning of upādi seems to have become more and more widespread with the development of monastic Buddhism, while the objective meaning of upādi became forgotten along with its metaphorical structure. It is quite possible that the confusion between the two occurred in the context of nirvana and this eventually led to the replacement at a later stage.

\section{Upädisesa within the context of nirvana}

Nirvana is, according to Gombrich, part of an extended metaphorical structure that embraces enlightenment and its opposite.

His argument relies largely on the sermon that is known in English as the Fire Sermon, ${ }^{34}$ but in Pali is called the Áditta-pariyaya, 'The way of putting things as being on fire'. The term pariyāya means literally 'a way round' and is applied to the mode of teaching in the suttanta, ad hominem, discursively, applied method, illustrated discourse and figurative language. The opposite of this word is nippariyaya and is applied to the systematised presentation of the doctrine in the abhidharma, the abstract general statements. ${ }^{35}$

We can find a similar approach in the Northern Buddhist tradition. Yaśomitra says in his Sphuțārtha, a commentary on the Abhidharmakośabhāsya: 'The elucidation of the sütra is, indeed, contingent, not definitive like the abhidharma. ${ }^{36}$ 'Contingent' (äbhiprāyika) here seems to mean 'dependent on context'. It is the adjectival form of abhiprāya, which is 
derived from abhiprê meaning 'to go near to, approach; to approach with one's mind, to think of' according to MWD. The noun abhiprāya means 'purpose, intention, wish, opinion, meaning and sense (as of a word or of a passage)'. It thus refers to meaning depending on context. In other words, the exposition of the sütra depends largely on taking words in their context, on taking the text as a whole.

What is taught through the image of fire ${ }^{37}$ in the aditta-pariyayya? It reads as follows:

O monks, all is on fire. And, O monks, what all is on fire? I say, Oh monks, eye is on fire. Visual objects are on fire. Eye-consciousness is on fire. Eye-contact is on fire. This feeling which is caused by the eye-contact and is pleasant, painful or neither painful nor pleasant is also on fire. With what is it on fire? It is on fire with the fires of passion, hatred and delusion. It is on fire with birth, old age, death, sorrow, lamentations, sufferings, grieves, and distresses. ${ }^{38}$

What it says is that 'all' is on fire with passion, hatred and delusion and later that the key to being liberated is to lose interest in (nibbindati) the 'all' and, as a consequence, to put out the triple fire of passion, hatred and delusion. ${ }^{39}$ By the word 'all' it means the organs, i.e. the five sense faculties and the mind; their objects, such as visual objects; six consciousnesses; six contacts and the feelings arising from these contacts. In other word, it simply lists all parts of our cognitive process. ${ }^{40}$

What is the fuel of the triple fire in this context? In the Adittasutta in the Samyuttanikaya ${ }^{41}$ the five aggregates are used metaphorically as the fuel of a triple fire: passion, hatred and delusion. Within the early canon, the five aggregates are often designated as upādana-kkhandha , which is typically translated as 'the aggregates of grasping' by taking the subjective meaning of upādanna. The awkwardness in understanding this word is easily solved if 'fuel', the objective meaning of upādanna, is taken into consideration. It simply means 'the aggregates of fuel' or 'the aggregates as fuel' if taken as a descriptive compound (karmadhäraya). Since nirvana literally means 'going out', what has to go out is this triple fire of passion, hatred and delusion fuelled by these five aggregates.

On the origin of the word upādisesa, Nyannamoli said in his translation of the Khuddakapātha, The Minor Readings, ${ }^{42}$ that the term upādisesa was originally used as a medical term, meaning 'a residue of a poisoned arrow's poison still clinging to the wound after treatment', and then used 'figuratively of the Arahant, who during the remainder of his life manifests the "residue of clinging left" in the form of the five-category process, which, however, "will cease" with the end of his life-span'.

Nyānamoli ${ }^{43}$ traces this medical usage of the word to the Sunakkhattasutta in the Majjhimanikäya ${ }^{44}$ Here the blessed one gives the simile of a person 
who is 'pierced by an arrow thickly smeared with poison' ${ }^{45} \mathrm{He}$ is treated by a surgeon who opens the wound with the knife and drains the poison off from his wound. Although it looks as if there is no poison remaining, there is a possibility that some is left. Thus, the surgeon instructs him to take care of the wound by eating only beneficial foods, taking a regular bath, and not exposing the wound to the wind. If he follows this instruction he will be cured and if not he will die. The word upädisesa is used here to describe whether any poison is still remaining in him or not: 'He might extract the arrow, he might drain off the poison leaving some behind but thinking none remained ... the poison has been drained off so that none is left, there is no danger for me. ${ }^{96}$ Ñyannamoli, however, could not clearly explain how this medical term, 'the residue of a poisoned arrow's poison still clinging', becomes used to mean 'the five aggregates'.

If we take upādi in upādisesa to mean 'fuel', the objective meaning of upādanna, we can easily understand what upādisesa means in the context of nirvana. What is called nirvana with a remainder of clinging is, as mentioned before, the state where the above triple fire is extinguished yet the fuel, the aggregates, is still remaining; whereas nirvana without a remainder of clinging is the state where there is no more fuel, the aggregates, left. Since there are no more rebirths in this state, it can also be regarded as going out or extinction. ${ }^{47}$

This later state is the starting point of the ontological questions about nirvana: we can ask 'Where does the candle's flame go after going out?' and the answer may be 'It goes back to its origin', 'It goes to nothing' or 'That cannot be answered'. I discuss this question later in detail in Chapter 4, under 'The Theravāda exegetical position on nirvana' and Chapter 5, under 'The Sautrāntika's criticism of ontological issues surrounding nirvana'.

What is the textual evidence to support this explanation? A small passage in both the Itivuttaka in the Pali and the Chinese translation by Xuan-zang ${ }^{48}$ is the best known example to support this Theravāda exegetical tradition on the two nirvana theory: both nirvana elements are applied to a saint (arahant).

What is, $\mathrm{O}$ monks, the nirvana element with a remainder of clinging? Herein, O monks, a monk is a saint (arahant) whose impurities are destroyed, who has reached perfection, who has done what should be done, who has laid down the burden, who has reached the highest goal, whose bonds leading to becoming are exhausted, and who is liberated through perfect knowledge. In him, the five faculties still remain, through which, as they have not been destroyed, he undergoes the pleasant and the unpleasant; he experiences happiness and suffering...

What is, $\mathrm{O}$ monks, the nirvana element without a remainder of clinging? Herein, O monks, a monk is a saint (arahant) ... For him, 
O monks, all feelings, in which he takes no delight will become cool right here; this is called, monks, the element of nirvana without a remainder of clinging. ${ }^{49}$

Although this sutta is frequently referred to as textual evidence, it does not actually mention the five aggregates expected from the metaphorical structure as well as the Theravāda exegetical tradition. This could be the reason why scholars like Husita Koudazu have said that upādi as meaning the five aggregates could not be found within the early canon. ${ }^{50}$ In fact, its description of saupādisesa nibbānadhätu refers to the five faculties (pañcindriyāni), as in the above mentioned Aditta-pariyayya. ${ }^{51}$

How he uses the five faculties (pañcindriyāni) seems to differentiate a saint (arahant) from an ordinary monk. Through the going out (nibbāna) of the triple fires, a monk leaps into the state of a saint (arahant) in whom there is no more impurity left (khịnasava). Nirvana is, as Gombrich says, "not a "thing" but the experience of being without greed, hatred and delusion'. ${ }^{52}$ The outcome of his experience, 'going out', is the firm belief that he is no longer bound to endless rebirth. ${ }^{53}$ This is why what comes after the description of nirvana is always 'the cry of jubilation', ${ }^{54}$ seen here as 'whose impurities are destroyed, who has reached perfection, who has done what should be done'.

On emerging from this experience this monk is a saint (arahant). Although he is back to normal, he is different from before: he has a firm control of his mind (manoindriya). However, he still is in contact with the outside world through his five sense organs and, as a consequence, he sometimes experiences suffering or happiness. The Buddha, the best example of a saint (arahant), for example, in the Avassutasutta in the Samyuttanikāya feels pain in his back and wants to stretch it. ${ }^{55}$ Since a saint (arahant) has firm control over his mind, he, unlike an ordinary monk, no longer forms any attachment to external objects. When the Itivuttaka passage says 'In him, the five faculties still remain, ... he experiences happiness and suffering', we can see that a cognitive process is going on, even after this nirvana with a remainder of clinging.

In the early Chinese canon ${ }^{56}$ our cognitive process is explained as follows: consciousness (vijñana) arises by reason of faculty (indriya) and of object (vișaya); the coming together of the three is contact (sparśa); conditioned by contact, feeling (vedanā), apperception (samjña $\bar{a})$ and volition (cetanā) arise. Although the typical passages in the Pali canon tend to omit apperception and volition and go directly to thirst $(\tanh \bar{a}),{ }^{57}$ one passage in the Majjhimanikāya ${ }^{58}$ shows what is missing between feeling (vedanā) and thirst (tanhā). After 'feeling (vedanā )', it says 'what one feels one perceives, what one perceives (sañjānati) one reflects about (vitakketi), what one reflects about one is obsessed with (papañceti) ${ }^{9} .{ }^{59}$ Thus the cognitive process described in the Pali canon could be more or less the same as that in the Chinese canon. 
Table 2.1 Five aggregates and cognitive process

\begin{tabular}{|c|c|c|c|c|c|}
\hline $\begin{array}{c}\text { Five } \\
\text { gogregates }\end{array}$ & \multicolumn{5}{|c|}{ Cognitive process } \\
\hline \multirow{2}{*}{ rūpa } & indriya & \multirow{5}{*}{$\begin{array}{c}{[\text { sparśa }]} \\
= \\
\text { coming } \\
\text { together of } \\
\text { three }\end{array}$} & \multirow[b]{3}{*}{ vedanā } & \multirow[b]{4}{*}{ saṃjñā } & \\
\hline & vișaya & & & & \\
\hline vedanā & & & & & \\
\hline saṃjñā & & & & & \\
\hline sampskāra & & & & & cetanā \\
\hline vijñāna & vijñāna & & & & \\
\hline
\end{tabular}

Note: This table is based on typical passages in SA (TD2: 71c9; TD2: 87c-88a).

In Sue Hamilton's book Early Buddhism: A New Approach the human cognitive process in terms of the five aggregates is mentioned in this context. She understands rüpa in the sense of both the living locus of subjectivity and the sense organs, vedana in the sense of the initial feeling of awareness, samjiñ $\bar{a}$ in the sense of being the process of identifying what that initial feeling of awareness is and vijñana in the sense of cognising something. ${ }^{60}$

Later she explains samskāra in the cognitive process as one's affective response to whatever one is experiencing. ${ }^{61}$ These volitional activities correspond to volition (cetan $\bar{a}$ ) seen in the above Chinese passage explaining the human cognitive process. Table 2.1 shows how this cognitive process is related to the five aggregates.

The significance of no-self (anätman) in terms of the cognitive theory could be that there is no need for a self (ätman), the subject of cognition, behind the five aggregates to explain the cognitive process. In other words, our cognitive process could be represented through the collective operation of the five aggregates and, in this respect, the Itivuttaka's description of saupädisesa nibbānadhātu seems to keep the objective sense of the word upādi.

Nirvana without a remainder of clinging is explained here as 'for him, $\mathrm{O}$ monks, all feelings (vedana $)$ in which he takes no delight will become cool right here'. This clearly shows that there is no more cognitive process going on at this stage, the final moment of the saint (arahant). That is to say, the remaining aggregates are finally extinguished.

Peter Masefield has argued in his paper 'The nibbāna-parinibbāna controversy' that the idea 'that the Buddha taught dhamma merely for the sake of what must now be seen as some lesser, or at least intermediate, goal would seem somewhat out of keeping with the teachings of the Nikāyas' ${ }^{62}$ Bronkhorst has also argued in his book The Two Traditions of Meditation in Ancient India that 'the distinction between Nirvāṇa with and without 
a remainder of upādi, in spite of its later currency (see La Vallée Poussin, 1925: 171-77, 179-80), was initially no more than an attempt to find a middle course between the original idea of Nirvanna in this life and the later tendency to place Nirvāna after death' ${ }^{63}$ However, the reason why Buddhism focuses more on nirvana during life, saupādisesa nibbānadhātu, seems to be that it automatically leads to final liberation, anupādisesa nibbānadhātu, from the chain of rebirth.

Unlike Jainism, in which all action must bear fruit, only intentional action in the Buddhist system can eventually lead to a future result. The famous statement in the Ariguttaranikāya makes this point: 'It is intention (cetanā), O monks, that I call karma. Having intended, one does karma through body, speech, and mind. ${ }^{96}$ Since in their view all action will eventually produce a result, Jains try not to do any act even just before death. That is why a voluntary starvation to death is the best possible way to liberation in Jainism, ${ }^{65}$ and this is actually said to be how Mahāvīra died. So Jainism focuses more on what a Buddhist would call the final nirvana, anupādisesa nibbānadhātu.

By contrast, since only intentional action will eventually produce a result, if a Buddhist monk has achieved firm control over his mind, so that all defilements have ceased and no further defilements will be produced, his final liberation, anupādisesa nibbānadhātu, is already confirmed at this stage, saupādisesa nibbānadhātu. This is why one who attains saupādisesa nibbānadhätu is called a saint (arahant), literally 'one who deserves praise', which in Jainism is only applied to the revealers of the religion and is used synonymously with Bhagavat, Jina and Tirthankara ${ }^{66}$ In other words, in early Buddhism the focus is more on nirvana in this life.

\section{Upädisesa within the context of the four noble persons}

In the early canon, the word sa-upapdisesa is sometimes used to describe the first three stages of the four noble persons (ariyapuggala): a stream-enterer (sotāpanna), a once-returner (sakadāgāmin), a non-returner (anāgāmin) and a saint (arahant) ${ }^{67}$

In the Saupādisesasutta in the Anguttaranikāya, the word saupādisesa is used by the blessed one to describe nine noble persons: five sub-divisions of nonreturner, antarāparinibbāayin, upahaccaparinibbāyin, asan̈khāraparinibbāyin, sasan̄khāraparinibbāyin and akanițthagāmin; a once-returner (sakadāgāmin); and three kinds of stream-enterer (sotäpanna), ekabījin, kolankola and sattakkhattuparama ${ }^{68}$

In the Tissasutta in the Anguttaranikāya, two kinds of arahant, ubhatobhāgavimutta and pañ̃āavimutta, are described as anupädisesa; while kāyasakkhin, dițthipatta, saddhāvimutta, dhammānusārin and animittavihārin are described as saupādisesa.$^{69}$ While the four noble persons and their subcategories $^{70}$ are listed in the Saupädisesasutta, the seven noble persons ${ }^{71}$ are listed in the Tissasutta. 
Before going further, we need briefly to survey how the above technical terms have been understood in the Theravāda Buddhist tradition. Here is a brief explanation of the four noble persons and their sub-categories. ${ }^{72}$

An average person in Buddhism is called puthujjana, or ordinary person. When he is about to start Buddhist practices he is called gotrabh $\bar{u}$, literally one who has become a member of the spiritual lineage. ${ }^{73}$ This gotrabhu is, according to his dominant spiritual faculties ${ }^{74}$ further divided into two subcategories: dhammānusārin, follower of the teaching, if his dominant faculty is insight (paññindrya), and saddhānusārin, follower through faith, if his dominant faculty is faith (saddhindriya). ${ }^{75}$

In the next stage, he becomes the first of the four noble persons: a stream-enterer (sotāpanna), which is further divided into three kinds according to their spiritual developments. At first, he is called sattakkhattuparama, one who has at most seven more births. When he acquires the pure faculties (anāsavaindriyā $),{ }^{76}$ he becomes kolankkola, one who passes from one family of beings to another. When he further develops the faculties of concentration and of insight, he becomes ekabijin, one who has one more existence. ${ }^{77}$ In the next stage, he is a once-returner (sakadāgämin), the second of the four noble persons.

The third is a non-returner (anāgamin) and is classified into five subcategories: antaräparinibbāyin, one who reaches nirvana within the first half of his life, ${ }^{78}$ upahaccaparinibbāyin, one who reaches nirvana after crossing half his life-time ${ }^{79}$ asankkhäraparinibbāyin, one who reaches nirvana without great effort; sasanikhäraparinibbāyin, one who reaches it with great effort; and uddhamsota-akanițthagāmin, one who goes upstream and to the highest gods. The last noble person in this list is of course a saint (arahant) and is, according to the method of achieving the state, of two kinds: ubhatobhägavimutta, released on both sides; and pañ̃̃avimutta, released by insight. ${ }^{80}$

The typical description of the seven noble persons in the Theravāda Buddhist tradition can be found, though not the old one ${ }^{81}$ in the Visuddhimagga. ${ }^{82}$ It starts from a person who has acquired the faculty of faith, of concentration or of insight.

When a person acquires the faculty of faith ${ }^{83}$ he becomes saddhānusārin, follower through faith, at the moment of stream-entry, and then he becomes saddhävimutta, one who is released through faith, at the later stages. When a person acquires the faculty of concentration, he is called kayasakkhin, bodily witness ${ }^{84}$ and then he, at the last stage, becomes ubhatobhaggavimutta, released on both sides. In the above Tissasutta, animittavihärin, one who stays unaffected, is mentioned instead of the traditional saddhānusārin, follower through faith. ${ }^{85}$ Although the Pali commentary glosses it as saddhänusärin, ${ }^{86}$ it could be a special term for one who is about to acquire the faculty of concentration, which seems to be missing in the traditional list of the seven noble persons. When a person acquires the faculty of insight, he becomes dhammannusärin, follower of the teaching, ${ }^{87}$ at the moment of stream-entry, 
Table 2.2 Four and seven noble persons

\begin{tabular}{|c|c|c|c|c|c|}
\hline \multicolumn{3}{|c|}{ Four noble persons } & \multicolumn{3}{|c|}{ Seven noble persons } \\
\hline \multicolumn{2}{|c|}{ Main category } & Sub-category & $\begin{array}{l}\text { Faculty of } \\
\text { faith }\end{array}$ & $\begin{array}{c}\text { Faculty of } \\
\text { concentration }\end{array}$ & $\begin{array}{c}\text { Faculty of } \\
\text { insight }\end{array}$ \\
\hline \multicolumn{2}{|l|}{ Puthujjana } & & & & \\
\hline \multirow[t]{4}{*}{ Saupādisesa } & Gotrabhū & $\begin{array}{l}\text { Saddhānusārin } \\
\text { Dhammānusārin }\end{array}$ & Saddhānusārin & $\begin{array}{l}{\left[\text { Animitta- }^{-}\right.} \\
\text {vihārin }^{\mathrm{a}}\end{array}$ & Dhammānusārin \\
\hline & Sotāpanna & $\begin{array}{l}\text { Sattakkhattuparama } \\
\text { Kolaṃkola } \\
\text { Ekabījin }\end{array}$ & \multirow{4}{*}{ Saddhāvimutta } & \multirow[b]{3}{*}{ Käyasakkhin } & \multirow[b]{3}{*}{ Dițthipatta } \\
\hline & Sakadāgāmin & & & & \\
\hline & Anāgāmin & $\begin{array}{l}\text { Antarā-parinibbāyin } \\
\text { Upahacca-parinibbāyin } \\
\text { Asankhhāra-parinibbāyin } \\
\text { Sasañkhāra-parinibbāyin } \\
\text { Uddhamsota- } \\
\text { akaniț̣agāmin }\end{array}$ & & & \\
\hline Anupādisesa & Arahant & $\begin{array}{l}\text { Ubhatobhāgavimutta } \\
\text { Pañ̃̄āvimutta }\end{array}$ & & $\begin{array}{l}\text { Ubhatobhāga- } \\
\text { vimutta }\end{array}$ & Pañ̃̃āvimutta \\
\hline
\end{tabular}

Note: This table is based on explanations from Dutt (1960: 252-71), Katz (1982: 83-95), and Ñyāṇamoḷi (1976: 770). a According to the Tissasutta (AN IV: 74-9). It lists animitta-vihārin instead of the traditional saddhānusārin.

and then he becomes ditthipatta, one who has grasped vision at the later stages. When he reaches the last stage, he becomes paññavimutta, released by insight. Thus, saupādisesa is used in describing the first three stages of the four noble persons and dhammānusārin and animittavihārin ${ }^{88}$ according to the Tissasutta.

The two kinds of arahant, ubhatobhāgavimutta and paññavimutta, are described as anupādisesa in the Tissasutta. This usage is further confirmed from the story in the first part of the sutta. Here, nuns surrounding the blessed one are described by two devas as anupädisesa: 'Lord, these nuns are wholly freed and without attached remainder. ${ }^{89}$ Since these nuns, Mahāpajāpatī and five hundred others according to E. M. Hare, ${ }^{90}$ are still alive, what this word anupādisesa designates could not be one enlightened after death, but a living arahant. They are illustrated in Table 2.2.

In the Theravāda tradition, the four noble persons tend to be understood entirely in terms of their giving up a traditional list of ten fetters. ${ }^{91}$ They are often divided into two categories: the lower fetters (orambhägiya-samyojana), which belong to the world of desire (kämadhātu), and the higher fetters (uddhambhāgiya-samyojana), which belong to the world of form (rūpadhātu) and the world of the formless (ärüpyadhātu). 
Table 2.3 Ten fetters

\begin{tabular}{|c|c|}
\hline \multicolumn{2}{|r|}{ Ten samyojana } \\
\hline $\begin{array}{c}\text { orambhāgiya- } \\
\text { samyojana }\end{array}$ & 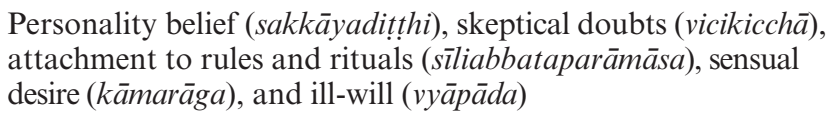 \\
\hline $\begin{array}{l}\text { uddhambhägiya- } \\
\text { samyojana }\end{array}$ & $\begin{array}{l}\text { Desire for form (rüparāga), desire for the formless (arūparāga), } \\
\text { pride (māna), restlessness (uddhacca), and ignorance (avijjā) }\end{array}$ \\
\hline
\end{tabular}

Sources: SN V pp. 60-1, DN III p. 234, AN IV pp. 67-8.

Nayanatiloka in his Buddhist Dictionary says that

He who is free from 1-3 is a Sotapanna, or Streamwinner, i.e. one who has entered the stream to Nibbāna, as it were. He who, besides these 3 fetters, has overcome 4 and 5 in their grosser form, is called a Sakadāgämi, a 'Once-Returner' (to this sensuous world). He who is fully freed from 1-5 is an Anāgāmi, or 'Non-Returner' (to the sensuous world). He who is freed from all the 10 fetters is called an Arahant, i.e. a perfectly Holy One. ${ }^{92}$

Thus, upādi in this context of the four noble persons refers to fetters (samyojana) that are said to bend man to the wheel of transmigration and is, like the four kinds of upādanna in the later systematization, ${ }^{93}$ taking its subjective meaning.

However, this interpretation of the four noble persons is, as pointed out by Somaratne, ${ }^{94}$ problematic if we consider typical passages that describe the four noble persons in the Pali canon: ${ }^{95}$

a stream-enterer ... a monk after vanishing of the three fetters has entered the stream, has forever escaped the woe, is affirmed, assured of final enlightenment . . . a once-returner ... after the vanishing of the three fetters and the attenuation of passion, hatred, and delusion, the monk returns only once more to this world. And only once more returning to this world, he puts an end to suffering ... a nonreturner ... after the vanishing of the five lower fetters, however, the monk becomes one who is spontaneously born (opapatika) and there he reaches complete nibbāna without ever returning from that world ... a saint (arahant) ... after the vanishing of cankers ( $\bar{a} s a v \bar{a})$, being cankerless, he reaches already in this world, the freedom which is concentration, the freedom which is understanding, after personally experiencing and comprehending that state. ${ }^{96}$ 
Although the nikāya passages agree with Nyanatiloka's above description of a stream-enterer and a non-returner, they differ in the description of a once-returner and a saint (arahant). What makes a person become a oncereturner is not by 'overcoming 4 and 5 in their grosser form' but by 'weakening passion, hatred, and delusion'. What makes a monk become a saint (arahant) also is not by 'being free from all ten fetters' but by 'the vanishing of cankers' (āsavānam khayā).

Moreover, explaining the four noble persons entirely in terms of their giving up of the traditional ten fetters is a later development, within the abhidhamma. It is in the Dhammasangani that a once-returner was first explained in this sense. It says that one attains the second path, a once-returner, while diminishing sensual desire and ill-will (kāmarāgavyāpādānam patanubhāvāya); whereas one attains the third path, a non-returner, while giving up sensual desire and ill-will without any remainder (kämarägavyāpädānam anavasesappahānāya) ${ }^{97}$ This new interpretation was later applied in the Puggalapaññatti ${ }^{98}$ and also appeared in the Dharmaskandha $a^{99}$ in the Chinese abhidharma. Therefore, not only could fetters not be the exclusive means through which the four noble persons are differentiated in the early canon, but this tendency should be regarded as a later abhidhammic development.

The Pali canon actually shows other ways of differentiating the four noble persons. In the Sankhittasutta in the Samyuttanikäya, ${ }^{100}$ the four noble persons are judged according to the degree to which five spiritual faculties: faith, energy, mindfulness, concentration, and insight, have been cultivated. By the fulfilment and accomplishment of all five, one is a saint (arahant); by having them to a lesser degree, one is a non-returner; and by having them to successively lesser degrees, one is a once-returner, a stream-enterer, dhammānusārin and saddhānusārin. ${ }^{101}$ The Ekäbhiñ̃asutta in the Samyuttanikāya ${ }^{102}$ also gives a long list in terms of the degree of the same five spiritual faculties starting from a saint (arahant); five sub-divisions of a non-returner, a once-returner, two sub-divisions of a stream-enterer, and two sub-divisions of gotrabh $\bar{u}{ }^{103}$

Moreover, in the small suttas in the Indriyasamyutta in the Samyuttanikäya, six organs, such as the faculties of sight, and five sensations, i.e. the faculties of pleasure, displeasure, satisfaction, dissatisfaction and indifference, are separately used as a measure to qualify as a stream-enterer or a saint (arahant). These suttas say that 'when a noble disciple (ariyasāvaka), Oh monks, truly understands the arising of, the perishing of, the satisfaction in, the danger in and the escape from these six organs, this noble disciple is called a stream-enterer', ${ }^{104}$ and the same is said of the five sensations. ${ }^{105} \mathrm{In}$ the case of a saint (arahant), they say that 'when a monk, O monks, having truly known the arising of, the perishing of, the satisfaction in, the danger in, and the escape from these six organs, becomes released without any further attachment, this monk is called a saint (arahant), ${ }^{106}$ and the same is said of the five sensations. ${ }^{107}$ 
In the later abhidhamma tradition, ${ }^{108}$ these various faculties are classified and enumerated as twenty-two: six organs, female organ, male organ, vital organ, five sensations, five spiritual faculties and three pure faculties, i.e. anañ̃āataññassāmītindriya, añ̃̃indriya, and añ̃āatāvindriya. ${ }^{109}$ One thing common to the last three pure faculties is that they all share the word añña, perfect knowledge. The word añña is in the early canon often used to express the moment when a disciple claims to have won arahant-ship, ${ }^{110}$ and the phrase 'to be established in perfect knowledge (añ̃naya santhtăti)' is sometimes used to denote a saint (arahant). ${ }^{111}$ In fact, faculties and perfect knowledge (añña $)$ are mentioned together in the four small suttas called Pubbärämasutta in the Samyuttanikāya. ${ }^{112}$

In the later Chinese abhidharma text, the Jñanaprasthāna, ${ }^{113}$ the four noble persons are described according to the number of faculties they have among the twenty-two faculties, and the Abhidharmakośabhāssya also has its own classification of the four noble persons in terms of the number of faculties. ${ }^{114}$ Moreover, the key factors to differentiate the seven noble persons, who share most of their technical terms with the four noble persons, are not ten fetters but three of the five spiritual faculties. ${ }^{115}$

Therefore, fetters could not be the only means through which the four noble persons are classified and this tendency was instead the outcome of the later systematisation in the abhidharma literature.

\section{The non-returner and the two nirvana elements}

A. O. Lovejoy in his paper 'The Buddhist technical terms upādāna and upädisesa' wrote that 'the oldest and probably the most numerous texts point to the interpretation of upādisesa suggested by Oldenberg. ${ }^{116}$ That suggested interpretation of upādi is of course the subjective one: attachment or defilement.

Hermann Oldenberg, who interprets upādi in the ethical, or subjective, sense, argued that the expression anupādisesa nibbānadhätu contains a tauto$\operatorname{logy}$ as 'without a remainder of attachment' is the same as nirvana, whereas saupādisesa nibbānadhātu describes the incomplete, or inferior, nirvana known as a non-returner. ${ }^{117}$ Peter Masefield's argument also follows this line of thought. ${ }^{118} \mathrm{He}$ has tried to ignore the above-mentioned passage from the Itivuttak $a^{119}$ by emending the verse that it follows. However, Peter Harvey has successfully criticised this argument by showing some parallel passages in the Samyuttanika $y a^{120}$ and the Dighanikāya ${ }^{121}$ which confirm the wording of the Itivuttaka ${ }^{122}$ The problem behind their arguments is that they took the subjective meaning of upa adi, which is used in the context of the first three noble persons, to explain two nirvana elements, whereas it is the objective meaning that is relevant.

There are two major pieces of textual evidence they put forward to support their view. In the Suttanipata, ${ }^{123}$ monks gathered and approached the blessed 
one to ask the fate of Kappāyana at death. The question is: 'Did he gain quenching (without grasping) or did he have some grasping remaining?"124 At first glance, it looks as if it is a question of whether he died as a saint (arahant), referred to by the word nibbäyi, or as a non-returner, referred to by the word saupādiseso. However, it is a question whether he passed away as a saint (arahant) or as one of the three lower noble persons. In fact, the commentary seems to follow this interpretation: 'How was he released? Was it through anupādisesa nibbānadhātu like asekha, or was it through sa-upādisesa like sekha? ${ }^{125}$

As Norman has pointed out, the nirvana element (nibbānadhātu) is not applied to saupādisesa, while it is applied to anupādisesa. ${ }^{126}$ In fact, only a saint (arahant), asekha, can automatically pass away through anupādisesa nibbānadhätu. That is to say, saupādisesa here is used not in the context of the two nirvana theory but in the context of the four noble persons. If the word upādi in the saupādisesa has got the subjective meaning, i.e. defilements or fetters, how many nirvanas are we to accept? From Table 2.2 we may have to say that even saddhānusārin and dhammānusārin, two sub-categories of gotrabhu , have attained nirvana.

Moreover, the answer from the blessed one confirms the Theravāda exegetical tradition: 'He has cut off craving for name-and-form in this world. He has passed beyond all birth and death, the stream of thirst, which has long been latent (in him). ${ }^{127}$ In other words, he has been a saint (arahant) for a long time through the saupādisesa nibbānadhätu and now he is finally liberated through the anupādisesa nibbānadhātu.

Another piece of textual evidence presented is the passage in which a remainder of clinging (upādisesa) is used to describe a pair along with perfect knowledge (añña). It says that if a monk has faith in the Buddha's instruction and lives in unison with it, he expects one of two fruits: 'One of two fruits is to be expected: perfect knowledge (añña) in this very life, or if there is a remainder of clinging (upädisesa), the state of non-return. ${ }^{.128}$ The assumption that a remainder of clinging (upädisesa) is a yardstick to distinguish a non-returner (anāgāmin) from a saint (arahant) is largely based on this passage. ${ }^{129}$

It looks as if the word upādisesa was used in the context of the two nirvana theory, which would not be quite satisfactory if we consider some passages in the early canon in which perfect knowledge is used together with the four noble persons. I. B. Horner argued, though not precisely, that the alternative in this passage hinges not on the presence of a remainder of clinging but on the presence of perfect knowledge in the monk: either he has achieved perfect knowledge (añ̄̃a) or not. ${ }^{130}$

In the Nalakapānasutta in the Majjhimanikāya, ${ }^{131}$ although the description of the four noble persons is almost the same as that of typical nikäya passages seen above ${ }^{132}$ the description of the saint (arahant) is 'established in perfect knowledge (añña $)^{\prime}$ instead of the usual 'vanishing of cankers $(\bar{a} s a v \bar{a})$ '. 
If the word perfect knowledge (añña) is used instead of the straightforward word arahant, not only does it mean a saint (arahant), a simple substitution by the word perfect knowledge, but it could also imply the categorization of the noble persons through the faculties seen above. In other words, perfect knowledge was used in the context of the four noble persons.

The word aññ $\bar{a}$ is then further used together with the five sub-categories of a non-returner. In the early canon, we can see the description of the seven fruits or results. These results could be expected when a monk has cultivated the seven limbs of wisdom (bojjhanga), ${ }^{133}$ the five spiritual faculties (indriya) ${ }^{134}$ the four bases of psychic power (iddhipa $\bar{a} d a)^{135}$ or the concentration by mindfulness of breathing in and breathing out (ānāpannasati). ${ }^{136}$ Here is the usual passage of the seven fruits: ${ }^{137}$

What are the seven fruits, the seven results? [1] He attains perfect knowledge (añña $)$ earlier ${ }^{138}$ in this very life. [2] If he does not, then he attains perfect knowledge at the time of death. [3] If he neither attains perfect knowledge earlier in this very life nor at the time of death, then he, having ended the five lower fetters, becomes antaräparinibbāyin. [4] . . upahaccaparinibbāyin. [5] . . asañkhāraparinibbāyin. [6] . . . sasañkhāraparinibbāyin. [7] . . uddhamsoto akanițțagāmin.

Although the above passage is usually found isolated in the fifth book of the Samyuttanikaya in the Pali canon, its Chinese equivalent is found in both the Dirgha-āgama and the Samyukta-ägama. ${ }^{139}$ A slightly different version of this kind is also found in the Purisagatisutta in the Anguttaranikāya ${ }^{140}$ and its Chinese equivalent in the Madhyama-ägama. ${ }^{141}$ Thus, the idea of the seven results seems to have been widely accepted within the early Buddhist community.

If we look at the seven results carefully, we can classify them into two main categories: perfect knowledge (añña), either earlier in this very life or at death, and one of the five sub-categories of the non-returner. This division into main categories concurs not only with the above question in the Suttanipāta ${ }^{142}$ but also with the above standard passage listing the two results. In fact, the two results appear next to the seven results as a fruit of cultivating the four bases of psychic power (iddhipāda) in the Samyuttanikāya ${ }^{143}$ According to its equivalent in the Samyukta-āgama, ${ }^{144}$ cultivating the seven limbs of wisdom (qi-jue-fen, 七覺分) will lead not only to the two and the seven results but also to the four results, i.e. the four noble persons.

Thus, two pieces of textual evidence put forward could simply be a shortened version of the above seven results and, in this respect, the word upādisesa in this context could not have the same sense as when it is used in the context of the two nirvana theory. In other words, upādi in this passage cannot be understood in its objective sense, as in the context of the two nirvana 
theory, but is to be understood in its subjective sense, as in the context of the four noble persons.

Although these two pieces of textual evidence are not quite enough to support this view, there is one sütra found in the Chinese Ekottara-ägama that seems to support it. Traditionally, this sütra was regarded as the Chinese equivalent of the famous Itivuttaka passage ${ }^{145}$ in the Pali canon. ${ }^{146}$ It reads: ${ }^{147}$

There are two nirvana elements. What are the two? They are nirvana with a remainder of clinging and nirvana without a remainder of clinging. How is it called nirvana with a remainder of clinging? A monk, by destroying the five lower fetters, that is to say, one who has attained nirvana in the intermediate state (antaräparinirvāyin), ${ }^{148}$ does not return to that world [of desire]. That is why it is called nirvana with a remainder of clinging. How is it called nirvana without a remainder of clinging? A monk, by destroying impurity and accomplishing purity, witnesses himself [in this very life] the liberation through mind (cetovimukti), the liberation through wisdom (prajñavimukti) and himself delighted. He really knows 'birth is destroyed, the holy life is fulfilled, and there is no more birth [in this world]'. That is why it is called nirvana without a remainder of clinging.

The first answer designates a non-returner (anāgämin) through the term antarāparinirvāyin, one of its five sub-categories; the second answer denotes a saint (arahant) through 'the cry of jubilation'. Thus, the word upadhi in this case should be taken to mean fetters or defilements, as regularly used in the context of the four noble persons.

However, there are some philological problems with accepting this small sütra as a genuine one. First of all, we cannot find this sütra in the Pali Anguttaranikāya. It is well known that the Chinese Ekottara-ägama has a different origin from the Pali tradition. Although the seven books of the Chinese abhidharma are said to belong to the Sarvāstivādin, we cannot say that the same school is responsible for the four Chinese aggamas. They were in fact collected and translated independently without mentioning which sects they belong to. According to Bareau, the Dirgha-ägama would be of the Dharmaguptaka school and the two versions of the Samyukta-ägama would be of the Kāśyapiya school. ${ }^{149}$ Although the Ekottara-ägama is said to be translated from a manuscript belonging to the Mahāsānghika tradition, that is mere speculation. According to Lamotte, the Ekottara-ägama was 'translated between 397 and 398 by Gautama Sanghadeva, using a recension established in North-West India or Serindia and containing numerous Mahāyāna additions'. ${ }^{150}$

The Sarvāstivādins seem to think that there was no complete explanation of two nirvanas in the early canon (sütras) apart from mentioning their names: 
nirvana with and without a remainder of clinging. ${ }^{151}$ Since the Sarvāstivāda abhidharma also supports the Theravāda exegetical perspective on the two nirvana theory, ${ }^{152}$ the above sütra could not have originated from the mainstream Sthavira tradition to which both the Theravādin, one of the subcategories of the Vibhajyavādin, and the Sarvāstivādin belong. ${ }^{153}$ The presence of this sütra, however, suggests that there could have been sects, probably in the Mahāsānghika tradition, that developed their own theory on the two nirvana elements.

Second, we cannot rely on the Chinese technical terms, especially when they are related to nirvana. Unlike in Pali or Sanskrit, there are no grammatical inflections in Chinese. The word nei-pan (涅槃), the usual Chinese translation of the word nirvana, is also used to translate such words as parinirvāna, nirvrti, parinirvrta and parinirvāyin. The Chinese translation of the word antaräparinibbāyin, for instance, is zhong-pan-nei-pan (中般涅槃), in which the same word nei-pan (涅槃) is used. Moreover, the word wu-yunei-pan (無餘涅槃), the usual Chinese translation of 'nirvana without a remainder of clinging', is applied to the Pali word anupāda parinibbāna, 'nirvana without any further attachment' in the Madhyama-ägama's equivalent of the above mentioned Purisagatisutta in the Anguttaranikāya. ${ }^{154}$

Although the same term is used in the Chinese translation, the meaning is totally different. Nirvana without any further attachment is the word not for the last moment of a saint (arahant) but for the moment of enlightenment of one whose cankers (äsava) have vanished. In other words, it could not be nirvana without a remainder of clinging (anupādisesa nibbānadhātu) but must be nirvana with a remainder of clinging (saupādisesa nibbānadhātu), which is usually translated into Chinese as you-yu-nei-pan (有餘涅槃).

If we consider that the Madhyama-ägama was translated by the same translator, Gautama Sanghadeva, as the Ekottara-ägama, ${ }^{155}$ this confusion could play a part in the presence of the above sütra. In other words, this sütra could be the outcome of a confusion between anupāda parinibbāna and anupādisesa nibbānadhātu.

Although we could ignore the validity of the above Chinese sütra for these suggested reasons, we still need to explain how the state of non-return becomes so close to the state of arahantship. It is well known that the four noble persons are by stages known as 'the four pairs and eight individuals' (cattāri purisayugāni ațtha purisa-puggalā) ${ }^{156}$ In this formula each of the four noble persons is further divided into the way (magga) and the fruit (phala). The stream-enterer, for instance, is divided into the way of the stream-entry (sotapattimagga) and the fruit of the stream-entry (sotäpattiphala). Each of the four ways (magga) is simply the practice that leads to the corresponding fruit (phala). All stages in this formula are heading towards the final fruit, the fruit of a saint (arahant), and to reach the goal is basically like going up a staircase. 
However, this hierarchical structure becomes 'physically unbridgeable'157 at a certain point. Practising the way of non-return leads to the vanishing of the five lower fetters and, as a consequence, one has achieved the fruit of the non-return: spontaneously rising (opapātika) and then reaching final nirvana without ever returning from that world. Considering the early Buddhist promise of reaching sainthood (arahant) in this very life (ditthe va dhamme), it is almost impossible for the same person to practise the way of sainthood after reaching the fruit of non-return. This obvious gap could suggest that before the two noble persons, the non-returner and the saint (arahant), were placed in this hierarchical structure, they had already been conceptualised separately. In other words, the non-returner was originally conceived not as an intermediate state on the way to arahantship but as an independent state almost corresponding to nirvana.

Within the early Buddhist canon, the word non-returner (anāgamin) was sometimes replaced by the expression 'of a nature not to return from that world (anāvatti-dhammo tasma lokā '). This expression seems to correspond to the early Upanișadic idea of liberation described in two of the oldest Upanișads: the Bṛhadāranyaka Upanișad and the Chāndogya Upanișad. ${ }^{158}$

It is well known that at the time of the Veda, living for 100 years was compared to immortality. ${ }^{159}$ From the Brāhmana period, the idea of a next life was introduced and it consisted of two worlds: the world of gods (devaloka), which is deathless, and the world of fathers (pitrloka), where there are endless rebirths, i.e. people die again and again (punar mrtyu). ${ }^{160}$

When it comes to the early Upanișadic period, the world of Brahman (brahmaloka) was regarded as the highest and one who succeeded in reaching this world through knowledge and sacrifice was believed not to return to the human condition again: he is liberated from endless rebirth. The Bṛadäranyaka Upanișad, which is believed to predate Buddhism, explains this state as follows: "A person consisting of mind comes to the regions of lightning and leads him to the worlds of Brahman. These exalted people live in those worlds of Brahman for the longest time. They do not return (na punar ävrttih). ${ }^{161}$ In the Chandogya Upanisad, those who proceed along the Brahman path and reach the world of Brahman are likewise said not to return to this human condition again. ${ }^{162}$

This early Upanișadic idea of liberation seems to correspond to the Buddhist expression 'of a nature not to return from that world (anāvatti-dhammo tasma loka a)', which sometimes replaces the word non-returner (anāgāmin) in the Buddhist canon. The difference between the two concepts seems to be on ontological one. While in the Upanișad the person does not return to the human condition as he stays there, in the world of Brahman, forever as a liberated soul, the person in Buddhism does not return since he is about to be finally liberated there. However, they share the idea of the final departure from the human condition towards liberation. 
In the Brahmāyusutta, in the Majjhimanikāya, for example, the fate of a 120-year-old Brahman called Brahmāyu was described as follows:

Clever, monks, was the Brahman Brahmāyu; he followed after dhamma according to various parts of dhamma, and he did not annoy me with questionings about dhamma. Monks, Brahmāyu the Brahman, by the complete destruction of the five lower fetters binding to this lower, is of spontaneous uprising, one who attains nirvana there, of a nature not to return from that world. ${ }^{163}$

In the canon, the same passage is applied to two other lay disciples. They are Pukkusāti, a young man of family, who was killed in an accident with a cow when he had been searching for a bowl and robe in order to receive ordination, ${ }^{164}$ and Dīghāvu, a layman suffering from disease, who passed away soon after meeting the Blessed one. ${ }^{165}$ Brahmāyu in the above case was too old to become a monk. One thing in common in all three occasions is that the idea of non-return is applied to a lay disciple who is as knowledgeable as a monk ${ }^{166}$ yet for some reason cannot go forth from home to homelessness.

In the early canon, we can see the soteriological limitation for the laity. In the small suttas in the Indriyasamyutta ${ }^{167}$ while the term 'noble disciple' (ariyasāvako) is used to describe a stream-enterer, it is a monk (bhikkhu) who is said to be a saint (arahant). Although F. L. Woodward discounted this by commenting 'a monkish point of view' ${ }^{168}$ it is a common phenomenon in the early canon. In fact, the highest stage that can be reached by a lay follower is the state of non-return. Although we can see an effort to apply the hierarchy of the four noble persons to the obvious Buddhist social hierarchy - monks, nuns, laymen and laywomen - in Mahäparinibbänasuttanta in the Dighanikayya ${ }^{169}$ the early canon tends to make a clear distinction between 'monks and nuns' and 'laymen and laywomen'. ${ }^{170}$ In the Nilakapānasutta, ${ }^{171}$ while all the four noble persons could be monks or nuns, only the first three stages could be reached by laymen or laywomen. In other words, the state of non-return is the maximum achievement for lay people, and only monks or nuns can achieve sainthood.

Although the term arahant was applied in the $R g$-Veda to the god Agni and then used as a term for an honorific title bestowed upon some high official in the Śatapatha Brāhmana, ${ }^{172}$ it was used differently among the recluse groups during the time of the Buddha. In Jainism it was used synonymously with Bhagavat, Jina and Tirthaikara ${ }^{173}$ while in the early Buddhist canon it appeared as the term for a person with magic powers (iddhi), such as the six heretical leaders and Kassapa before ordination, or a person who performed physical austerities in the forest. ${ }^{174}$ That is to say, this term seems to have been widespread among the recluses at the time of the Buddha to designate a person who deserved praise for some reason, such as religious leadership, magic powers or asceticism. 
Considering that the idea of non-return could be widely spread among Brahmans and their followers, the Buddha seems to use this term as a kind of metaphor for the laity's equivalent of the recluse's sainthood (arahant). This could explain why the expression 'in nature not to return from that world (anāvatti-dhammo tasmā lokā)' was repeatedly applied to laity when it appeared independently. Placing it below the state of sainthood (arahant) could also have another meaning: it seems to allude to the Brahmanical liberation by saying that our ideal is higher than yours.

As seen above, a non-returner (anāgämin) is, by definition, one who will experience nirvana while alive in the pure abodes and then go beyond rebirths. Although he will not come back to the human condition due to the lack of the five lower fetters that bound him into the world of desire ( $k \bar{a}$ madhätu), he still needs to destroy the higher fetters (uddhambhägiya-samyojana) to attain nirvana after his spontaneous uprising (opapātika) in the pure abodes in the world of form (rüpadhätu). In this respect, it can be regarded as the final departure from the human condition; it cannot be regarded as nirvana or liberation. Thus, it seems to be far-fetched to say that the original pair of the two nirvana theory were non-returner (anāgāmin) and sainthood (arahant).

The double aspect of the word upādi seems to cause many exegetical problems in the abhidharma tradition. In fact, the Mahāvibhāṣassástra ${ }^{175}$ the exegesis of the Jñanaprasthāna, was well aware of the two different meanings of the word: upadhi as defilement (kleśopadhi) and upadhi as birthbody (janmakāyopadhi). Thus we need to treat this problem from a wide abhidharmic perspective. 


\section{DEVELOPMENTS OF THE TWO NIRVANA THEORY}

The Jñannaprasthāna, the last book of the Sarvāstivāda abhidharma, survives only in a Chinese translation and is the only text in both Northern and Southern abhidharmic traditions where the two nirvana theory was explained from the abhidharmic point of view. In fact we cannot find any explanation of the two nirvana theory in the seven books of the Pali abhidhamma. Most explanations we have are from their exegetical works.

Before going into these explanations on nirvana with and without a remainder of clinging, we need briefly to survey how nirvana has been understood from the perspectives of the later systematisations both of the Pali abhidhamma and of the Sarvāstivādin's abhidharma works.

As to the origin of the abhidharma literature, some Japanese scholars have suggested that it was to be found in dialogues concerning the doctrine (abhidharmakathā), or monastic discussions in catechetical style characterised by an exchange of questions and interpretative answers intended to clarify complex or obscure points of doctrine. ${ }^{1}$ But most Western scholars agree that it originated from lists (mātrk $\bar{a})$ of all topics of the Buddha's teaching arranged according to both numerical and qualitative criteria. ${ }^{2}$

Mātrka are comprehensive lists to collect and preserve doctrinal concepts used in the nikäyas. An early list of this kind could be the Sangitisuttanta ${ }^{3}$ of the Dìghanikāya in Pali or the Samgìtisūtra of the Dìrghägama in Chinese. The first of the seven Chinese abhidharma books, the Samgītiparyāyaśăstra, is in fact a commentary on this text. ${ }^{5}$

Since they articulate doctrines through classifications and definitions, there is no place for metaphorical or contextual explanations in this genre. They prefer clear simple concepts to the complex ambiguities of metaphor. Thus nirvana, which was used in the metaphorical sense of 'blowing out' within the early canon, became a technical term within the abhidhamma: a term to be rigorously defined and classified.

Within the abhidhamma works, thus, problems tend to occur when the definition of a dharma conflicts with the definition of another dharma or when the classification of a dharma overlaps with the classification of another 
dharma. In fact, these problem areas were the starting point of the abhidharmic developments of Buddhist doctrines.

In this chapter, I discuss the development of the nirvana concept in both the Pali abhidhamma tradition and the Chinese abhidharma tradition and then examine how this development affects the two nirvana theory in the Jñannaprasthāna and in the Theravāda exegetical traditions.

\section{The Pali abhidhamma works}

Nirvana with and without a remainder of clinging is hardly mentioned within the seven Pali abhidhamma works. In fact, the word nibbāna is not used in the main body of the Dhammasangani, the first and oldest work in the Abhidhamma-pitaka. It prefers the expression asaikkhatā dhātu, which also belongs to the sphere of mental data base (dhammāyatana). ${ }^{6}$

The word dhātu is usually translated by 'element' and always refers, according to L. S. Cousins, ${ }^{7}$ to a distinct sphere of experience. Visual object, for example, is perceived only by the faculty of sight and not by any of the other five faculties. The word dhätu seems first to be used with asankhatā in the Bahudhātukasutta in the Majjhimanikāya in order to distinguish the unconditioned as an object of experience from the conditioned. ${ }^{8}$ Since the term asankkhatā in the Theravādin abhidhamma retains its earlier usage, nirvana, ${ }^{9}$ this expression seems to be established to distinguish conceptually the unconditioned element of enlightened experience from all others.

Unlike the early canon (nikäyas), where doctrines were expressed through metaphors and contexts, the abhidhamma works articulate doctrines through classifications and definitions. Nirvana was first distinguished, as a kind of classification, from the five aggregates in the Dhammasangani in the following way: 'Which are dhammas with condition? They are the five aggregates: form, feeling, apperception, volitional activities and consciousness. Which are dhammas without condition? They are the unconditioned element.' ${ }^{10}$ Later in the Dhätukathä, it is explicitly stated that 'the unconditioned is not classified as an aggregate'. ${ }^{11}$ The definition of nirvana was first seen in the Vibhanga. It places the unconditioned (asankhatā), which is nirvana, both in the sphere of mental data base (dhammäyatana) ${ }^{12}$ and in the element of mental data base (dhammadhātu), ${ }^{13}$ and establishes a basic definition of nirvana based on the Nibbannasutta ${ }^{14}$ as follows: 'What is the unconditioned element? It is the cessation of passion, the cessation of hatred and the cessation of delusion. ${ }^{15}$

The outcome of this early classification and definition was that nirvana was the unconditioned (asankhatā), which was different from the five aggregates and was made up of the cessation of passion, hatred and delusion. On top of this notion, the Theravāda abhidhamma seems to have a monistic approach towards this dhamma: nirvana is the one and only unconditioned. 
The Kathāvatthu in this respect gives us much valuable information. First of all, the view that there are two cessations, extinction through knowledge (patisañkhānirodha) and extinction without knowledge (appațisankhānirodha) in Pali, which are two kinds of nirvana, is refuted in the second chapter. ${ }^{16} \mathrm{It}$ asks ' $O$ the two nibbānas, is one high one low, one excellent one deficient, one superior one inferior, and is there a boundary or difference, a line or interval between them?'17 The answer is no. In other words, there cannot be any hierarchy, superior or inferior, or division in nirvana. ${ }^{18}$

Moreover, the Kathāvatthu also rejects the idea that anything apart from nirvana can be unconditioned. There are six short discourses on nirvana in the sixth book of the Kathavatthu. ${ }^{19}$ The subjects discussed are fixation (niyäma), dependent origination (paticcasamuppāda), the four noble truths (sacca), the four formless spheres (äruppajhāna), the absorption of extinction (nirodhasamāpatti) and space ( $\bar{a} k \bar{a} s a)$. When the opponent insists that these are unconditioned, it replies that if any one of them is unconditioned, it should be regarded as nirvana, as there is only one unconditioned thing. Since the unconditioned cannot be plural, it is not possible for nirvana and something else to be unconditioned.

This rejection of plurality was, according to André Bareau, based on the analogy of infinite space, in which there is no limit, and was supported by the following unique argument: 'If there were various Absolute (unconditioned), various nibbānas, there would be between them a demarcating limit, one here and the other there. ${ }^{, 20}$ I discuss problems or side effects caused both by this abhidhamma definition and classification of nirvana and by the rejection of plurality of the unconditioned in the next chapter, under the heading 'The Theravāda exegetical position on nirvana'.

The rejection of plurality in the Pali abhidhamma seems to cause some difficulties concerning the two nirvanas, with and without a remainder of clinging, in the later exegetical traditions. The word $d h \bar{a} t u$, which is applied in both cases, seems to suggest that the difference between them is conceptual, as they both belong to the sphere of mental data base (dhammäyatana), like the unconditioned elements. Buddhaghosa, nevertheless, has to make an excuse first in his Visuddhimagga before commenting on the two nirvana theory by saying, 'The aim of the Buddha, etc. is one because there is no distinction. ${ }^{21}$

\section{The Chinese abhidharma works}

It is well known that while the Pali abhidhamma accepts only one unconditioned thing (dhamma), nirvana, the Chinese abhidharma accepts three, space $(\bar{a} k \overline{a s} a)$ and two extinctions: extinction without knowledge (apratisamkhyänirodha) and extinction through knowledge (pratisamkhyänirodha), which is the equivalent of nirvana. Like the Pali abhidhamma seen above, these three unconditioned things are said to belong both to the spheres of mental 
Table 3.1 Relative chronology of Chinese adhidharma texts

\begin{tabular}{|c|c|c|}
\hline \multicolumn{2}{|c|}{ Early period } & Sañītiparyāya, Dharmaskandha, Prajñaptiśāstra \\
\hline \multirow[t]{2}{*}{ Middle period } & Earlier & Dhātukāya, Vijñānakāya \\
\hline & Later & Prakaraṇapāda, Jñānaprasthāna \\
\hline \multirow[t]{2}{*}{ Late period } & Earlier & Vibhāṣāśāstra, Abhidharmahṛdaya \\
\hline & Later & $\begin{array}{l}\text { Tattvasiddhiśāstra, Abhidharmakośabhāṣya, } \\
\text { Nyāyānusāra, Abhidharmadīpa }\end{array}$ \\
\hline
\end{tabular}

Sources: Cox (1998: 171-3), Frauwallner (1995: 13-14).

data base (dhammāyatana) and to the elements of mental data base (dhammadhātu), yet do not belong to any of the five aggregates. ${ }^{22}$

According to E. Frauwallner, the abhidharma classification, which is based primarily on the five aggregates (skandha), is the oldest one and is termed pañcaskandhaka. ${ }^{23}$ This old system of classification was step by step replaced in the Chinese abhidharma by a new and more comprehensive system called pañcavastuka, the five categories of form ( $r \bar{u} p a)$, mind (citta), mental states (caitta), states not associated with mind (cittaviprayukta) and the unconditioned (asamskrta). The unconditioned is a new category, not found in the old classification of the five aggregates (pañcaskandhaka). ${ }^{24}$

The process of adopting this new system in the Sarvāstivādins' abhidharma was slow and gradual. It was applied in the Dhätukāyapādaśāstra and the Prakaranapādaśāstra, which are, according to Pu-guang (普光), ${ }^{25}$ a disciple of Xuan-zang, written at the beginning of the fourth century after the final nirvāna of the Buddha. ${ }^{26}$

Modern scholars, although they differ slightly, place these texts together with the Vijñānakāyaśāstra and the Jñānaprasthānaśāstra in the middle period of abhidharma development, whereas the Samgītiparyāyaśāstra and the Dharmaskandhaśästra, which applied the old system and relied more on quoting sutras, are placed in the early period.

Among the four texts in the middle period, the Prakaranapādaśāstra and the Jñanaprasthānaśāstra are regarded as more advanced texts since they show great developments in both organisation and doctrinal exposition. ${ }^{27}$ While both classifications were applied in the Dhātukāyapādaśästra, ${ }^{28}$ the Prakaranapādaśāstra ${ }^{29}$ applied the new system alone. Thus the new system may have become fully established at some time between when the two texts were written. Within the Sarvāstivādin abhidharma tradition in this middle period, the abstract concepts, or dharmas, were, under the five new categories (pañcavastuka), further classified into around seventy sub-categories in terms of their distinctive intrinsic nature (svabhāva); later, in the Abhidharmakośabhāsya, they were enumerated as seventy-five. ${ }^{30}$ 
The three unconditioned things are first mentioned in relation to the pañcaskandhaka in the Dharmaskandhapādaśästra ${ }^{31}$ one of the early abhidharma texts, and then listed as real existents (dravya) under the new classification, pañcavastuka, ${ }^{32}$ in the Prakaranapādaśăstra. ${ }^{33}$ Since these new categories differ from those mentioned in the early canon, a new basis was needed to establish their authority. The concept of 'intrinsic nature' (svabhāva) plays a major role in this establishment; it was widely used from this middle period on.

In the Pali tradition, the word sabhāva is seen only once, in the Patisambhidamagga ${ }^{34}$ within the three Pitakas, but is used extensively for exegetical purposes in the Visuddhimagga and the main commentaries and sub-commentaries. ${ }^{35}$

Intrinsic nature in the Sarvāstivādins not only provides the basis for the new classification, but also functions as the determinant of its existential status: any concept or any dharma characterised by intrinsic nature is said to exist as a real existent (dravya); all other phenomena that one can experience exist as aggregations of these real existents and, as a consequence, they are said to exist as mere designations (prajñapti). ${ }^{36}$

Within the Sarvāstivāda abhidharma, extinction through knowledge (pratisamkhyanirodha) is regarded as the equivalent of nirvana ${ }^{37}$ and is characterised by its intrinsic nature, 'all extinction which is disjunction (visamyoga) ${ }^{\prime} .^{38}$ This dharma was defined in the Abhidharmakośabhāsya as follows: ${ }^{39}$

Disjunction from impure dharmas is extinction through knowledge. Knowledge (pratisamkhyā) is a special understanding, the penetration (pratisamkhyāna) of suffering and the other noble truths. The extinction which is to be attained by that is extinction through knowledge. For as in 'oxcart', the middle word is elided..$^{40}$

The Sarvāstivādins on the one hand insist on the existence of all dharmas in the three time periods, while on the other hand they accept the momentariness of conditioned dharmas. Moreover, dharmas are on a par: they are impersonal and do not 'possess' each other, like substances and properties in other scholastic systems. What looks like possession is just conjunction, a shift in position, within a series of aggregates (skandhasamtāna).

Thus, if a person, or technically a series of aggregations (skandhasamtāna), attains a certain defilement, it does not mean that the series possesses the defilement directly but means that there is the arising of the acquisition (prāpti) of that defilement in the series. ${ }^{41}$ Once there occurs the acquisition of the defilement, the acquisition (präpti) makes the defilement renew its existence and continue its activity: arising, duration, decay and ceasing, within the series until this acquisition is eliminated from the series. Thus, what changes momentarily is not the intrinsic nature (svabhāva) of a dharma 
but its activities - arising, duration, decay and ceasing - through its inherent characteristic (svalakșana) of impermanence.

This repeated ceasing was different from the two unconditioned extinctions: extinction without knowledge (apratisamkhyānirodha) and extinction through knowledge (pratisamkhyanirodha). For the Sarvāstivādins, the former is the perpetual non-existence of the future dharmas within a series of aggregates, while the latter is the perpetual separation of an impure dharma from a series of aggregates through the antidote, 'acquisition of disjunction' (visamyogaprāpti).

One of the common examples, though it seems to be of later origin, ${ }^{42}$ to explain extinction without knowledge (apratisamkhyānirodha) is a cognitive one. According to the Sarvāstivādins, only one type of consciousness operates at each moment within the series of aggregates (skandhasamtäna). At a certain moment of visual consciousness, even though other objects of visual consciousness as well as other types of consciousness and their objects exist in the future waiting to arise, they do not arise, because a particular visual consciousness has already arisen in the moment within the series. Those other particular objects and types of perceptual consciousness, having missed their opportunity to arise, are as if at a standstill; though they still exist as intrinsic nature (svabhāva) in the future time period, they will be forever incapable of arising. The person, the series of aggregates, is then said to have extinction without knowledge with regard to those that have not arisen. ${ }^{43}$ Thus, although it explains the future non-existence of a certain dharma within one's series, it actually occurs not because of the cessation or destruction of a dharma, which is impossible within the Sarvāstivāda system, but because of a deficiency of the conditions necessary for that dharma to arise.

What is the nirvana that in this abhidharma is called 'extinction through knowledge (pratisamkhyānirodha)'? In this system, it is impossible to destroy defilement and thus the elimination of a defilement is referred to as a 'separation' from the series. That is to say, the acquisition of the defilement is negated, or technically 'disjoined' (visamyoga), through the power of knowledge that terminates the junction between that defilement and the series of aggregates. By reason of this separation, then, there arises 'the acquisition of disjunction' (visamyogaprāpti) that serves as an antidote (pratipakșa), which henceforward prevents the junction between the defilement and this series. ${ }^{44}$

These two steps are later compared to throwing out a thief and closing the door or to catching an insect in a jar and plugging the jar's mouth. ${ }^{45}$ Extinction through knowledge ( pratisamkhyanirodha) is thus equated with nirvana not in the sense of cessation or destruction of defilement, but in the sense that defilement has been removed from a person and will henceforward be separated from him.

Therefore, nirvana as extinction through knowledge in the Chinese abhidharma has two distinctive features. First, it should be regarded as a 
real existent (dravya). The main role of nirvana in this case is henceforward to prevent a particular defilement from attaching to a person through the antidote, 'the acquisition of disjunction' (visamyogapräpti), which arises from knowledge ( pratisamkhyā). This role could not be fulfilled if it were nonexistent. In other words, nirvana must exist as a real existent (dravya) in the three time periods. ${ }^{46}$

Second, it is quite different from the two nirvana elements in the early canon. Nirvana in this case is used in a narrow sense applied to a single perpetual prevention of a certain defilement, while nirvana in the early canon is the cessation of the triple fire: passion, hatred and delusion. It is also quite different from the nirvana in the Pali abhidhamma, where it is the one and only unconditioned thing. In fact, nirvana as extinction through knowledge is multiple.

Later in the Mahāvibhāṣâsáastra it is explained as follows: 'there are as many extinctions through knowledge as there are objects of junction' ${ }^{47}$ In other words, a saint (arahant), who has nirvana with a remainder of clinging, in this system is the one who has terminated all junctions with impure objects and as a consequence has henceforward been protected from them through antidotes, 'the acquisition of disjunction' (visamyogapräpti). Thus, nirvana in a narrow sense called disjunction (visamyoga) is quite different from what is known as nirvana with and without a remainder of clinging. ${ }^{48}$

\section{The Sarvāstivāda interpretation in the Jñānaprasthāna}

The Jñanaprasthanna is the only abhidharma work in which the two nirvana theory is mentioned and interpreted. In the Sarvāstivāda tradition, the Jñannaprasthana is regarded as the body of six other abhidharma works, which are collectively entitled 'Abhidharma consisting of six feet' (sadpādäbhidharma) ${ }^{49}$ However, that does not mean that the Jñannaprasthāna was established earlier than the other six abhidharma works. In fact, the Jñannaprasthāna can be seen by its style and its detailed interpretations based on Sarvāstivāda orthodoxy to be among the latest of these seven works. ${ }^{50}$

After explaining the Sarvāstivādin's three extinctions, extinction through knowledge, extinction without knowledge, and impermanent extinction, ${ }^{51}$ it clarifies the two nirvana theory as follows:

What is nirvana with a remainder of clinging (sopadhiśeșanirvānadhātu)? A saint (arahant) has completely extinguished his impurity ( $k$ șināsrava); his vitality (âyus) alone exists; the series of primary elements (mahābhütāni) and secondary matter (upādāyarūpa) have not yet become extinct; the mental series supported by the five faculties is active as there is still a remainder of clinging. The complete cessation of all fetters (samyojana) which is obtained (präpta), 
possessed (pratilabdha), touched (sprșța), and realised (sākșātkrta) [by this saint] is what is called nirvana with a remainder of clinging.

What is nirvana without a remainder of clinging (anupadhiśeșanirvānadhātu)? A saint (arahant) has completely extinguished his impurity; his vitality has come to an end; the series of primary elements and secondary matter have already been destroyed; the mind supported by the five faculties is no longer active as there is no remainder of clinging. The complete cessation of all fetters is what is called nirvana without a remainder of clinging. ${ }^{52}$

Here we can see a coherence in approach towards the two nirvana theory between the Pali exegetical tradition and the Sarvāstivāda interpretation: both nirvanas are here ascribed to a saint (arahant) who has completely extinguished his impurity ( $k \sin$ ăsrava). It also puts an end to the speculation that nirvana with a remainder of clinging is achieved through the destruction of five lower fetters belonging to the world of desire. As it shows, it is attained through 'the complete cessation of all fetters (結, samyojana)'.

This passage also shows a doctrinal development of the two nirvana theory from the Sarvāstivādin's point of view. Although the five faculties (pañcaindriya) are mentioned, agreeing with the Itivuttak ${ }^{53}$ in the description of nirvana with a remainder of clinging, it is vitality (壽命: $\bar{a} y u$ ) that is mentioned first in this interpretation.

How did this vitality $(\bar{a} y u)$ come into the context of the two nirvana theory? One clue seems to come from the Pali Petakopadesa ${ }^{54}$ where vitality $(\bar{a} y u)$ was mentioned not in the context of nirvana with a remainder of clinging (sopadhiśssanirvānadhātu), like the Itivuttaka, but in the context of nirvana without a remainder of clinging (anupadhiśeșanirvānadhātu). ${ }^{55}$ The final nirvana can only be reached through the elimination of vitality.

Thus, vitality $(\bar{a} y u)$ could be first used to explain how the process of the final nirvana, nirvana without a remainder of clinging (anupadhiśeșanirvānadhātu), starts. The use of vitality $(\bar{a} y u)$ in the Petakopadesa passage clearly shows this is the case. ${ }^{56}$ Vitality ( $\left.\bar{a} y u\right)$, then, seems to be being applied backwards to nirvana with a remainder of clinging, since it gives such a clear distinction between the two nirvanas. From this clarity, explaining the two nirvana theory in terms of vitality may have become widespread among Buddhist communities in both Northern and Southern traditions.

In my opinion, the Jñanaprasthanna explanation of the two nirvanas could be in the middle between the old clarification by the five faculties (pañcaindriya) in the Itivuttaka ${ }^{57}$ and this new distinction by vitality $(\bar{a} y u)$ in the later systematisation. The author of the Jñannaprasthāna probably knew the Itivuttaka passage, yet not as an authentic sütra but as a form of the chanted verses. ${ }^{58}$ While both texts explain the cognitive process following nirvana with a remainder of clinging (sopadhiśeșanirvānadhātu), they are different in details in their explanation. In the Itivuttaka the cognitive 
process was explained through the relationship between the five aggregates shown in Chapter $2,{ }^{59}$ whereas in the Jñannaprasthāna it was explained through the continuation of the series of aggregates (skandhasamtāna), which was clearly influenced by the Buddhist theory of momentariness.

Especially for the Sarvāstivādins, vitality ( $\bar{a} y u)$ could solve one problem caused by the Buddhist theory of momentariness. In this system, only one dharma is working at a moment (kșana) ${ }^{60}{ }^{60}$ Basically, it is not possible for the five faculties (indriyas) to work together at the very moment when a monk emerges from nirvana with a remainder of clinging (sopadhiśeșanirvānadhātu). That is to say, a single dharma is probably needed to explain this very moment, like a starting point of our cognitive process. Vitality $(\bar{a} y u)$ can be an ideal fit in this case. We shall, however, see in Chapter 5, under 'The development of the two nirvana theory in the Mahāvibhāsạsáasstra', that the validity of this hybrid clarification of the Jñannaprasthāna was doubted by the author of the treatise. ${ }^{61}$

The Sarvāstivādins are sometimes called 'those who talk of causes' (設因 部, hetuvāda) according to the Chinese translation of the Vasumitra's Samayabhedoparacanacakra ${ }^{62}$ and the list of Bhavya. ${ }^{63}$ This other name seems to suggest that they are not only affirming the existence of dharmas in the three time periods, but also keen on explaining things through their causes. For the author of the Jñanaprasthāna, introducing vitality could be a big step forwards in searching for the foundation through which a monk emerges from nirvana with a remainder of clinging, the experience of the state where there is no more passion, hatred, delusion or any defilement.

Despite introducing vitality $(\bar{a} y u)$, he continued to use the old term, the five faculties ( pañcaindriya), in his explanation. Table 3.2 shows the sequence of how a series of aggregates (skandhasamtāna) continues from vitality in the Jñanaprasthāna explanation. ${ }^{64}$ How could this sequence from vitality to the five faculties and to mental series be justified? In fact, this sequence does not lack textual evidence in support.

First, vitality $(\bar{a} y u)$ was regarded as the basis of stability of the five faculties (indriyas) in the early Buddhist tradition. In the Mahāvedallasutta in the Majjhimanikāya, ${ }^{65}$ there is a conversation between Mahākoțthita and Sāriputta on the mutual relation of the mind and mental concomitants. When Sāriputta was asked the basis of the five faculties, he replied that they depend on vitality and then he added that vitality depends on warmth (usmā),

Table 3.2 The sequence of emerging from nirvana with a remainder of clinging

$\underset{\text { The series of aggregates (skandhasaṃtāna) }}{\longrightarrow}$


and the two are interdependent like the flame and the light of a lamp. Taking warmth $(u s m \bar{a})$ as secondary matter, we can easily explain the first sequence, from vitality to primary elements and secondary matter, as interdependent, while the five faculties depend on them.

The relationship of these three, vitality, warmth and the five faculties, seems to be extended to explain our life as psycho-physical phenomena, that is to say, the five aggregates consisting of name and form (nämarüpa). The material five faculties (indriyas) seems to be replaced by consciousness (vijñana) to give a kind of psycho-physical balance. In this way, minimum components of our life could be explained by three basic dharmas with different characteristics: vitality ( $\bar{a} y u)$, an abstract principle; warmth (usmā), a form of secondary matter; and consciousness (vijñanna), mental constituent.

Within the Sarvāstivāda tradition, the relationship of these three things, vitality, warmth and consciousness, is explained as interdependence or mutually to support one another. ${ }^{66}$ Its textual evidence came from the Phenasutta in the Samyuttanikayya ${ }^{67}$ 'When vitality, warmth, and consciousness abandon this body, then [a person] lies discarded food for others ${ }^{68}$ devoid of consciousness.' Wherever there is vitality there is warmth and consciousness and vice versa. In order for consciousness (vijñäna) to occur, sense faculties (indriya) and objects (vișaya) are required, since consciousness arises by reason of a faculty and its object. ${ }^{69}$ In this way, the whole sequence seen in the Jñanaprasthāna passage can be explained through mutual support.

Later in the Mahāvibhāṣāsāastra, the commentary on the Jñānaprasthāna, vitality $(\bar{a} y u)$ is further interpreted as the life faculty (jīvitendriya), one of twenty-two controlling faculties as well as one of fourteen dharmas not associated with the mind (viprayuktasamskära), and as homogeneous character (sabhägat $\bar{a})$, which determines the specific rebirth state of sentient beings. ${ }^{70}$ I discuss this matter in detail in Chapter 5, under 'The development of the two nirvana theory in the Mahāvibhāsāśsasstra'.

\section{The Theravāda exegetical tradition}

Nirvana with and without a remainder of clinging is usually interpreted as the cessation of defilements (kilesa-parinibbanna) and the cessation of the aggregates (khandha-parinibbāna) in the Theravāda exegetical tradition. ${ }^{71}$ Peter Masefield has argued that the above distinction could be traced back only as far as the fifth-century CE commentator Buddhaghosa. ${ }^{72}$

A lengthy and detailed explanation of the two nirvana elements can be found in the Visuddhimagga. It became widely accepted as the standard explanation and was used frequently in the post-Buddhaghosa period of Theravāda Buddhism. After making the excuse cited above, ${ }^{73}$ Buddhaghosa explains the two nirvana elements: 
but this [single goal, nibbana,] is firstly called with result of past clinging left since it is made known together with the [aggregates resulting from past] clinging still remaining [during the arahant's life], being thus made known in terms of the stilling of defilement and the remaining [result of past] clinging that are present in one who has reached it by means of development. But [secondly, it is called without result of past clinging left] since after the last consciousness of the arahant, who has abandoned arousing [future aggregates] and so prevented kamma from giving result in a future [existence], there is no further arising of aggregates of existence, and those already arisen have disappeared. So the [result of past] clinging that remained is non-existent; and it is in terms of this non-existence, in the sense that there is no [result of past] clinging here, that that [same goal is called] without result of past clinging left. $^{74}$

Although Buddhaghosa's explanation largely follows the Theravāda exegetical explanations of the two nirvana elements mentioned above, he adds some interesting remarks to clarify the final nirvana.

For the Sarvāstivädins nirvana is, as mentioned above, a real existent (dravya) and is understood in a narrow sense applied to a single perpetual prevention of a certain defilement ${ }^{75}$ whereas for the Sautrāntikas nirvana is not a real existent (dravyasat) but a mere designation (prajñaptisat), something spoken of conventionally, as well as 'non-existence succeeding existence (paścādabhāva)', like a sound that is non-existent before and will be non-existent after its occurrence. ${ }^{76}$

Although the Theravādins do not accept the idea that nirvana is mere non-existence, ${ }^{77}$ the way Buddhaghosa explains nirvana without a remainder of clinging reminds us of the Sautrāntikas' perspective, especially when he says 'there is no further arising of aggregates of existence and those already arisen have disappeared ${ }^{78}$ This could lead us to assume that the two nirvana theory was introduced by Buddhaghosa, a northerner, who went to Ceylon (Sri Lanka) early in the fifth century CE, and it is probably one of the reasons why Peter Masefield has argued that the two nirvana theory could only be traced back as far as Buddhaghosa.

However, we can see a prototype of this interpretation in the Nettippakarana and the Petakopadesa. Modern scholars have rejected the traditional Buddhist claim that both these texts were established at around the time of the first council by one of the Buddha's disciples, Mahā-Kaccā(ya)na. ${ }^{79} \mathrm{He}$ was, according to early suttas ${ }^{80}$ known as 'foremost of those who analyse in detail what has been stated in brief', and appears to have lived mostly in the rather remote south-west Kingdom of Avanti. ${ }^{81}$ From this, Ñyāṇamoḷi surmises that this compendious method could have been handed down orally in some skeleton form and then at some time between Asoka and the first 
century CE an attempt was made, somewhere in southern India, to set forth this method in the form of a treatise. ${ }^{82}$

According to A. K. Warder, both texts contain some new ideas, such as inherent nature (svabhāva), which were alien to the earlier Theravāda traditions. ${ }^{83}$ Since both texts under the name of Mahā-Kaccā(ya)na ware already in circulation among Sinhalese monks when Buddhaghosa arrived there, ${ }^{84}$ they seem to have reached Ceylon well before the fifth century CE. ${ }^{85}$ Although their canonicity was recognised only by Burmese Buddhists, they still were cited as authoritative by Buddhaghosa in his Atthasālinī and Visuddhimagga. ${ }^{86}$

The Nettippakarana has been regarded by modern scholars as somewhat older than the Petakopadesa since the latter presupposed the former. ${ }^{87}$ Yet it is not clear whether the word netti in both texts is a noun meaning simply 'guide' or is, as believed, a proper name designating the Nettippakarana. In fact their style and handling of the subject matter suggest the reverse order. While the former is even, clear, economical, neat and well exemplified, the latter is crabbed, only occasionally clear, redundant and sometimes poorly exemplified. From this, Ñyānamoḷi insists that the former, the Nettippakarana, seems to be the improved and revised version of the latter, the Petakopadesa. The description of the two nirvanas in both texts seems to support Ñyānamolii’s claim.

The Nettippakarana gives us a simple and clear explanation of the two nirvana theory. It explains them as follows: 'The state of being without thirst is nirvana with a remainder of clinging; with the breaking up of the body there is nirvana without a remainder of clinging. ${ }^{88}$ Whereas 'the state of being without thirst' corresponds to the cessation of defilements, 'the breaking up of the body' corresponds to the cessation of aggregates in this clarification. The word upādi here seems to be regarded as referring to the body $(k \bar{a} y a)$ because it is destroyed at the final stage. In fact, this agrees literally with the Sarvāstivādins' interpretation of the word upadhi as 'birth body' (janmakāya) ${ }^{89}$ in the Mahāvibhāṣassás̄stra.

By contrast, the Petakopadesa gives us an uneven but quite interesting explanation of the two nirvana theory. Here, the perfection of insight (vipassanā) is designated as nirvana with a remainder of clinging (sopādisesanibbānadhātu). After explaining that, it explains nirvana without a remainder of clinging (anupādisesanibbānadhātu) as follows:

By two steps a monk has done what he had to do. This is the nirvana element with a remainder of clinging. Through taking up his vitality $(\bar{a} y u)$ completely, through checking his life faculty (jivitendriya), suffering here has been destroyed and no further suffering arises. In that state the destruction, laying to rest, of these aggregates, elements and spheres and the non-linking, nonappearance, of other aggregates, elements and spheres, is nirvana without a remainder of clinging. ${ }^{90}$ 
The mention of vitality (壽命: $\bar{a} y u$ ) here requires special attention. As seen above, it was said to exist alone after the nirvana with a remainder of clinging in the Jñannaprasthāna, the seventh book of the Sarvāstivāda abhidharma ${ }^{91}$ and was interpreted later in the Mahāvibhāsâsásastra as life faculty (jīvitendriya) and homogeneous character (sabhāgatā). ${ }^{92}$ This similarity could suggests that vitality $(\bar{a} y u)$, instead of the five faculties mentioned in the Itivuttaka ${ }^{93}$ becomes the key element to distinguish the two nirvanas and that this exposition was probably well established not only among Northern Buddhists but also among Southern Buddhists around the first century CE. The explanation of nirvana without a remainder of clinging here seems to influence Buddhaghosa's interesting remark on the final nirvana in the Visuddhimagga: 'there is no further arising of aggregates of existence and those already arisen have disappeared'.$^{94}$

Under the influence of the Buddhist theory of momentariness, destruction alone cannot be enough to explain why it should be regarded as the unconditioned. Non-arising becomes a more important ingredient than destruction since every dharma is said to cease repeatedly due to its momentary nature. The mention of no further arising of suffering, aggregates and so on thus suggests that the theory of momentariness was already widespread around India at this stage and that with the coming of the Petakopadesa, Ceylon was probably under the influence of the Buddhist theory of momentariness well before the arrival of Buddhaghosa.

The Suttanipāta atțhakathā by Dhammapāla traces its interpretation of the two nirvana theory back to the Sundarikabhäradvajjasutta in the Suttanipāta. While the Buddha was talking about the qualities of the Tathāgata to a Brahman called Sundarikabhāradvāja, he said as follows: 'The Tathägata, who, seeing the end and destruction of fetters and birth, has thrust away the path of passion entire(ly), is purified, faultless, stainless, clear; he deserves the sacrificial cake'.$^{95}$ In Dhammapāla's commentary, 'the end and destruction of fetters' was interpreted as nirvana with a remainder of clinging, while 'that of birth' was interpreted as nirvana without a remainder of clinging ${ }^{96}$. Although we cannot be sure that in the original text the Buddha meant to speak so specifically in terms of the two nirvana elements, we still can see that this Suttanipatta passage fits the Southern exegetical explanation as well as the Northern interpretation of the two nirvana theory, including both the Sarvāstivādins and the Sautrāntikas. ${ }^{97}$

The best known exegetical passage to explain the two nirvana elements is in Dhammapāla's Theragāthā-ațthakathā. It reads as follows: 'By "quenched" it means two nirvanas, the nirvana element with a remainder of clinging which is the destruction of defilements, and the nirvana element without a remainder of clinging, which is the destruction of aggregates. ${ }^{98}$ The Dhammapada-atthakatha also says that the first is 'because the cycle of defilements has been destroyed' (kilesavattassa khepitattā), while the second is 'because the cycle of aggregates has been destroyed with the cessation of the 
[arahant's] last thought' (carimacittanirodhena khandhavatțassa khepitattā) ${ }^{99}$ We frequently see this type of explanation in the various $t \bar{i} k \bar{a} s$, exegeses of the atthakathās.

Taking 'clinging' as the aggregates seems to have been largely settled within Buddhist schools. Later in the Prasannapadā, Candrakīrti also adopted this interpretation. He said: 'By the word upadhi is meant the five aggregates as fuel, which is the cause of the conventionally designated self (ätman). ${ }^{, 100}$ 


\section{4 \\ NIRVANA IN THE THERAVĀDA BUDDHIST TRADITION}

In Chapter 3, we saw that the right interpretation of nirvana with and without a remainder of clinging is, agreeing with its metaphorical structure, as the cessation of all defilements during life for the former and the cessation of the aggregates at death for the latter. In the early canon, the state of nirvana without a remainder of clinging was often explained through the image of a fire extinguished. In fact, we can get an early idea of this state through one of the well known discourses concerning one of the four unanswered questions: the state of the Tathägata after death. As its name suggests, the early canon did not really answer this question and, as a consequence, there have been many attempts to fill 'the silence of the Buddha' through clarifying this metaphor of a fire extinguished.

One of the attempts to fill this silence is through the common Indian view on fire seen in the later Upanisads. F. Otto Schrader, for example, tried to interpret this state positively through clarifying this metaphor in terms of the so-called common Indian view based on several later Upanisads. ${ }^{1}$ According to him, 'an expiring flame does not really go out, but returns into the primitive, pure, invisible state of fire it had before its appearance as visible fire'. ${ }^{2}$ Thus, the enlightened person after death does not become nothing but returns to the primitive and pure state like the paramatman, the ultimate reality in Brahmanism. ${ }^{3}$

Peter Harvey has recently tried to interpret this state as something positive, not a state of nothingness, from the Dārukkhandhasutta in the Añguttaranikāya. ${ }^{4}$ Through the fact that the monk who possesses supernormal powers (iddhimant) can see earth, water, fire and air elements in a large log of wood because there are these elements in the log, he drew the following conclusion:

While to a Western-educated person, an extinct fire goes nowhere because it does not exist, the Buddha's audience in ancient India would generally have thought of an extinguished fire as going back into a non-manifested state as latent heat. The simile of the extinct fire thus suggests that the state of an enlightened person after death 
is one that is beyond normal comprehension, not that is a state of nothingness. ${ }^{5}$

Although the two interpretations are based on different sources, they have one thing in common: as a fire extinguished does not finally end its existence but goes back to its origin or latent state, the state of an enlightened person after death cannot simply be mere non-existence.

However, it has not been proved that the allegedly common Indian view was already presupposed in the early canon when the metaphor of a fire extinguished was used to explain what happens to an enlightened person after death. ${ }^{6}$ That is to say, it should be determined through the context in which this metaphor was used in the early canon. In this chapter, I am dealing with this problem by examining Buddhist methodology seen in the early canon, by clarifying the meaning of this metaphor in the context of Vacchagotta's unanswered questions and by exploring later developments, especially within the Therāvada system.

\section{Buddhist methodology}

In order to see how the metaphor of a fire extinguished was used in the dialogue between the Buddha and Vacchagotta, we may need to look at the methodology, or the way of thinking, underlying their conversation. The methodology used by the Buddha could be termed yoniso manasikära, meaning 'thinking according to the cause'.

This term has been translated in various ways as wise attention, proper attention, systematic attention, reasoning attention, critical reflection and thinking according to the law. 'Making in the mind', the literal meaning of manasikāra, seems to favour translating this word as 'attention'. Actually, manasikära is not included in the category of good dhamma (kusala dhamma) in the Dhammasangani but added later by Buddhaghosa in its commentary, the Atthasālinī, as one of nine states. ${ }^{7}$ That is to say, it is highly unlikely that attention was the original meaning of this word manasikara.

In the early canon, it is more likely to mean simply 'thought' or 'reflection' and is usually found together with yoniso. The word yoniso, an adverbial form of yoni, the womb, origin or way of birth, tends to mean 'from the origin, methodically, wisely and thoroughly'. This compound, thus, means 'thinking according to the origin' or 'reflecting from the origin', and was generally used in the early canon in three different ways.

First, it can be used as a means through which cankers (äsava) are removed according to the Sabbāsavasutta in the Majjhimanikāaya:

Then, Oh monks, what is the cessation of cankers (assava) of one who knows and of one who sees? There is thinking according to the 
cause (yoniso manasikära) and thinking without considering the cause (ayoniso manasikāra). Monks, from thinking without considering the cause cankers which had not arisen arise and also cankers which have arisen increase. But, monks, from thinking according to the cause cankers which had not arisen do not arise and also cankers which have arisen decline. ${ }^{8}$

Second, it was one of two conditions that lead to right understanding (sammādițthi) according to the Mahāvedallasutta in the Majjhimanikāya:

But how many conditions are there, friend, to bring about right understanding (sammādițthi)? There are indeed two conditions, friend, to bring about right understanding. They are the utterance of another [person] and thinking according to the cause (yoniso manasikāra). ${ }^{9}$

Finally, it is regarded as the base of mindfulness (sati), one of the seven facts for enlightenment according to the Āhārasutta in the Samyuttanikāya:

Then what, oh monks, is the cause (āhära) of the arising of mindfulness (sati) as a constituent of enlightenment which had not arisen and the cultivation and fulfillment of mindfulness (sati) as a constituent of enlightenment which has already arisen? There is, oh monks, a dhamma which is founded on mindfulness (sati) as a constituent of enlightenment. Thinking according to the cause indeed is here the cause (āhara) of the arising of mindfulness (sati) as a constituent of enlightenment which had not arisen and the cultivation and fulfilment of mindfulness (sati) as a constituent of enlightenment which has already arisen. ${ }^{10}$

In the Chinese canon, this word was translated as 'right reflection' (正思惟) ${ }^{11}$ and 'suitable reflection' (當思惟) ${ }^{12}$ and then later, in the Abhidharmakośabhāṣya translated by Xuan-zang, it was translated as 'making up one's mind correctly (如理作意), ${ }^{13}$ as opposed to 'making up one's mind incorrectly' (非理作意), which is the cause of ignorance (avidya ), the first of the twelve formulae of dependent origination. ${ }^{14}$

According to the MahāSakyamuniGotamasutta in the Samyuttanikāya, this methodology, thinking according to the cause (yoniso manasikära), played an important role in the Enlightenment of the Buddha. In the sutta, the blessed one looks back into the past when he was just a bodhisattva:

Before I was enlightened, oh monks, while I was a bodhisattva who was not fully enlightened, I thought: Oh! This world which is fallen into misery is being born, getting old, dying, falling away and 
getting born again. Yet it does not know the escape from this suffering and from decay and death. When indeed will the escape from them be known? I then thought, oh monks, 'From what that exists do decay and death come to be, from which cause is there old age and death?' Then oh monks I had a realisation of understanding through thinking according to the cause (yoniso manasikāra): 'When birth exists, decay and death come to be, with birth as condition, there is decay and death'. ${ }^{15}$

Here the problem of death turned out to be the crucial issue that the Buddha before enlightenment sought to overcome. Although it was not mentioned in this sutta, the Buddha before enlightenment could ask himself 'What is death?' as against 'What is life?' in accordance with the ordinary way of thinking.

The Buddha, according to Gombrich in his book How Buddhism Began, 'was not an essentialist, and in contrast to Brahmins was interested in how things worked rather than in what they were'. ${ }^{16}$ From the modern terminology, these two ways of looking at things seem to correspond to two types of methodology suggested by Karl Popper in his book The Open Society and Its Enemies: methodological essentialism and methodological nominalism.

Karl Popper explained the first, methodological essentialism, as to aim at finding out what a thing really is and at defining its true nature, by asking, for example, what movement is or what an atom is. The second, methodological nominalism, is to aim at describing how a thing behaves in various circumstances, by asking, for instance, how a planet moves or under what conditions an atom radiates light. ${ }^{17}$

His point, according to Gombrich, is that "knowledge and understanding do not advance through asking for definitions of what things are, but through asking why they occur and how they work ${ }^{18}{ }^{18}$ The content of yoniso manasikära could resemble modern scientific method. The question and answer given under yoniso manasikāra focused clearly on how or why things like old age and death occur. Late in this text, this method was regarded as a whole new one, 'not being heard of before' (pubbe ananusamuppāda) ${ }^{19}$ and as a means through which enlightenment was possible.

We can see another aspect of this new way of questioning and answering in the Phaggunasutta in the Samyuttanikäya. Here the Buddha actually took some questions from a monk, Moliya Phagguna, as unfit questions and suggested fit questions and answers based on his new way of thinking, yoniso manasikara. He asked the Buddha, when the doctrine of the four foods (āhära) was taught, 'Then, blessed one, who eats the consciousness-food?'20

The four foods (āhāra) are made up of physical food, sense-impressions, mental volitions and consciousness, and the last food is interpreted by Warder as 'experience through our sentient body'. ${ }^{21}$ This question thus means simply 'Who is conscious?'22 Here is the answer from the blessed one: 
The Buddha said this was not a fit question. I am not saying someone eats. If I were saying so, the question would be a fit one. But I am not saying so. Although I am not saying so, however, if you asked me 'Then the Blessed one, what has consciousness as food?', this would be a fit question. And the fit answer to it is that the consciousness food is the cause of future becoming and of rebirth. When that has come about there are the six senses. With the six senses as condition there is sense-contact. ${ }^{23}$

The Buddha further corrected Moliya Phagguna's questions such as 'Who contacts?' and 'Who feels?' to 'From which cause is there sense-contact?' and 'From which cause is there feeling?' From the Buddhist methodology, yoniso manasikāra, questions raised by Moliya Phagguna were unacceptable as they had already assumed an agent or subject, such as a soul (ätman), behind our cognitive activities.

While the Buddha explained our mental phenomena through the causal relationship between cognitive units, questions from Moliya Phagguna expect answers explaining our mental phenomena through the hierarchical relationship of the subject within, such as a soul (ätman), and cognitive activities outside, such as sense and feeling. If mental phenomena can be explained through the causal relationship between dharmas, there is no need to establish such a hierarchical subject-object relationship. Soul, according to Buddhism, is known neither by direct perception (pratyakșa), as are the objects of the five sense consciousnesses and the object of mental consciousness, nor by inference (anumāna), as are the five faculties (indriya) ${ }^{24}$

Since our cognitive activities can be explained through the causal relationship between dharmas that can be known either by direct perception or by inference, there is no need to accept the existence of a soul, which is not known and is not part of this causal relationship between phenomena. In this new way of thinking, yoniso manasikara, there is no place for something that is outside the range of this causal relationship.

In both suttas mentioned above, the answer given by the Buddha leads us to the formulae of dependent origination (paticcasamuppāda) consisting of ten or twelve dhammas. This could mislead us to assume that this way of thinking, yoniso manasikāra, can be applied only to the relationship between dhammas within the formulae of dependent origination. I hold that the scope of yoniso manasikāra is a lot wider.

We can see a kind of general rule beyond the chain of ten or twelve formulae within the early canon. It is 'When there is A, there is B; from the arising of A, B arises' (imasmim sati idam hoti imass'uppādā idam uppajjati). According to the very first part of the Udāna ${ }^{25}$ this general rule was built up on the basis of the Buddha's enlightened experience. That is to say, yoniso manasikara can be applied not only to the twelve dharmas within the formulae, but also to all causally related phenomena. 


\section{The Unanswered questions and the fire image in the early Upanișads}

A set of questions asked by Vacchagotta have been known as avyākata. Murti, in his book The Central Philosophy of Buddhism, has translated it as 'The Inexpressibles ${ }^{26}$ in accordance with his interpretation of these questions as 'a parallel with the Kantian antinomies' ${ }^{27}$ This translation is not correct literally because vyākata is the past passive participle of vyākaroti, meaning 'explain or answer'. The proper interpretation of avyākata should be, as pointed out by Jayatilleke, 'unexplained or unanswered' ${ }^{28}$

The set of ten or fourteen unanswered questions can be classified into four main categories. The four topics are whether the world is eternal, whether the world is finite, whether the soul (jiva or ätman) is the same as the body (sarīra) and the state of the Tathägata after death. Each issue consists of two or four alternatives: affirmative and negative for the two, or affirmative, negative, both and neither for the four.

For instance, the four sets for the last category are: 'the Tathaggata exists after death', 'the Tathägata does not exist after death', 'the Tathägata does and does not exists after death' and 'the Tathägata neither exists nor does not exist after death'. In the set of ten only the last topic, the state of the Tathägata after death, has four alternatives, whereas in the set of fourteen all the topics except the third one, the soul as body, have four alternatives.

Although Jayatilleke has relied largely on the set of ten, found in the Pali canon, ${ }^{29}$ the set of fourteen appears not only in the Sanskrit literature ${ }^{30}$ but also in the Chinese equivalent ${ }^{31}$ of the Pali suttas ${ }^{32}$ with the set of ten unanswered questions. That is to say, the Pali could be the only canon in which the unanswered questions enumerate ten.

There have been many attempts to solve the problems surrounding these unanswered questions. ${ }^{33}$ Main concerns can be of two kinds: whether the Buddha knew the answers to these questions, and on what grounds these questions were not answered. When it comes to our topic, the state of the Tathägata after death, they are: whether the Buddha accepts a certain state reachable by an enlightened one after death and on what grounds he wants this question to remain unanswered.

While Jayatilleke, taking a logical positivist position, seems to accept the existence of a transcendental state realisable after death yet considers that it is unanswered because this state is indescribable or logically meaningless, ${ }^{34}$ Kalupahana, from an empiricist point of view, rejects the existence of such a state on the same ground as the rejection of the Upanișadic conception of atman and explains the silence of the Buddha as his awareness of the limitations of empiricism. ${ }^{35}$ I think that the silence of the Buddha on this particular question could largely be responsible for his new way of thinking, thinking according to the cause (yoniso manasikara), if we consider how the metaphor of a fire extinguished was used in the dialogue between the Buddha and Vacchagotta. 


\section{The image of a fire extinguished in the Vacchagotta's question}

In the Aggivacchagottasutta in the Majjhimanikāya, the curious Vacchagotta asked the set of ten unanswered questions. The answer given by the Buddha to all his questions was simply 'I am not of a such view, Vaccha (na kho aham Vaccha evamditthi)'. ${ }^{36}$ After some additional questions from him, the Buddha struck back, asking the following questions concerning the state of the Tathägata after death using the image of a fire extinguished and of a palm uprooted:

If, Vaccha, this fire in front of you were to go out (nibbāyeyya), would you then know 'This fire in front of me has gone out'? Yes I would, Gotama. Again if you, Vaccha, were asked 'This fire which has gone out in front of you, in which direction - to the east, west, north or south - has it gone from here?', how would you answer? It does not fit, Gotama. This fire has blazed up through grass and sticks as fuel. Through using them up completely and through the non-supplying of anything else, it is said to have gone out with nothing to feed on' (anāhāro nibbuto). Even so, Vaccha, the material form (rüpa) of the Tathägata through which the Tathāgata could be identified should be known as 'abandoned, with root cut off, like a palm uprooted, destined to be non-existent, no longer reappearing in the future'. ${ }^{37}$

As we see from this passage, the Buddha was not entirely silent on this issue. He actually explained his position through his own methodology, thinking according to the cause (yoniso manasikāra) mentioned above, ${ }^{38}$ with the images of the extinguished fire and of a palm uprooted. He did not simply follow the way Vacchagotta had questioned him since he regarded his questions as unfit and saw a danger if he answered.

In fact, Vacchagotta's questions on the state of the Tathägata after death have already assumed a certain state reachable after the death of the enlightened one. In any case, affirmative, negative, both and neither, answering him means that the Buddha had to explain a certain state that was basically known neither through direct perception (pratyakșa), like material form (rüpa), feeling (vedanā) and so on, nor through inference (anumāna), like the faculty of sight. ${ }^{39}$ This state, like a soul (ätman) as we saw before, ${ }^{40}$ cannot be explained through his way of thinking, thinking according to the cause (yoniso manasikāra), which clarifies things through the causal relationship between dharmas that are known through either direct perception or inference.

Actually accepting the existence of the enlightened one after the final nirvana inevitably leads the Buddha to admit a soul (ätman), an agent or subject behind our cognitive activities, since the soul according to the 
Upanișads also has a transcendental state, like Brahman. As the Buddha shows in the Phaggunasutta seen above, ${ }^{41}$ how our cognitive activities work without admitting an agent, all he needs to do here is to show how a Tathägata, an enlightened one, finally passes away and no longer returns to endless rebirths; he does not need to admit a certain transcendental state, like Brahman, reachable after death. The image of the extinguished fire was applied in this context together with the image of a palm uprooted.

What is compared to a fire extinguished in the context of the final nirvana, nirvana without a remainder of clinging? As this discourse clearly shows, it is not nirvana itself but 'the material form (rüpa) of the Tathagata' and so on. Although it is not seen in the above passage, the Buddha not only mentioned material form but also the rest of the four aggregates, as does the Chinese equivalent of this Pali sutta in the Samyukta-ägama. ${ }^{42}$

What is extinguished in this final moment is, as expressed by Walpola Rahula, "the "being" composed of the Five Aggregates who realized Nirvāna' ${ }^{43}$ That is to say, what is extinguished like a fire in this final moment of nirvana cannot be nirvana itself but the five aggregates, conventionally designated as a person (puggala). Thus, the image of a fire extinguished here was used differently from nirvana with a remainder of clinging, where it is compared to the cessation of the triple fires of passion, hatred and delusion. ${ }^{44}$

How do these five aggregates finally cease like a fire extinguished? The answer was given through the words of Vacchagotta: 'This fire has blazed up through grass and sticks as fuel. Through using them up completely and through the non-supplying of anything else, it is said to have gone out with nothing to feed on' (anāhāro nibbuto).

The Buddha was consistent in saying there are rebirths with fuel and not without fuel. In another dialogue between the Buddha and Vacchagotta in the Kutūhalasālāsutta in the Samyuttanikāya, he explains this as follows:

You could doubt, Vaccha. You could be suspicious. Doubt has risen from the suspicious part. I indeed declare that there are rebirths with fuel but not without fuel. Just as, Vaccha, a fire is burning with fuel but not without fuel, I declare that there are rebirths with clinging but not without clinging. But, Gotama, in case that a fire has been carried a long way through the wind, what does the venerable Gotama consider as the fuel? In that case, I say the wind is fuel. For at that time the wind becomes its fuel. Again, Gotama, in case a being lays aside this body and then is born again in another body, what does the venerable Gotama consider as the fuel? In that case, I say thirst is the fuel. For at that time thirst becomes its fuel. ${ }^{45}$

We can see the similar use of the image of a fire's going out through lack of fuel elsewhere in the early canon. ${ }^{46}$ Steven Collins has tried to establish that the standard image of nirvana, when it is used as a soteriological metaphor, 
is not of wind or some other agent actively putting out a fire, but of a fire's automatic going out through lack of fuel. ${ }^{47}$ For example, one passage in the Majjhimanikāya reads as follows:

Just as an oil-lamp burns because of oil and wick, but when the oil and wick are exhausted, and no others are supplied, it goes out through lack of fuel, so the [enlightened] monk ... knows that after the break-up of his body, when further life is exhausted, all feelings which are rejoiced in here will become cool. ${ }^{48}$

It is 'lack of fuel' that is the main cause of the extinction of a fire in this context. This point is further confirmed from the simile of a palm uprooted. ${ }^{49}$ When a palm is uprooted, it cannot sprout a new trunk to continue in the future.

In order not to reappear in the future, there should be no more causes whatsoever to produce a new fire or to sprout a new trunk. Thus, the image of the extinguished fire and of a palm uprooted in this context explains that it cannot reappear in the future owing to a lack of any cause whatsoever.

In my opinion, this could be the best explanation of how the Tathaggata finally passes away and why he no longer returns to endless rebirths without admitting any transcendental state reachable after death. Although the Buddha was silent instead of replying to Vacchagotta's question, his solution looks as if he is answering by asking in return, as in Phagguna's case: ${ }^{50}$ 'This was not a fit question. I am not saying that the Tathägata exists, does not exist, does and does not exist or neither exists nor does not exist after death. If I were saying so, the question would be a fit one. But I am not saying so. Although I am not saying so, however, if you asked me "Then, Blessed one, how does the Tathägata finally pass away", this would be a fit question. And the fit answer to it is ...'

Earlier in this chapter, I showed that there are two main concerns around this last issue of the unanswered questions: whether the Buddha accepts a certain state reachable by an enlightened one after death and on what grounds he wants this question to remain unanswered. For the first matter the Buddha seems to leave such a state, a kind of absolute, aside, ${ }^{51}$ since it is outside the range of his methodology, which explains things through the causal relationship between phenomenal dharmas. For the second, I could say that his methodology, thinking according to the cause (yoniso manasikära), could help to account for his leaving questions on the state of the Tathaggata after death unanswered.

\section{The image of a fire in the early Upanisads}

How does the metaphor of a fire extinguished relate to the so-called common Indian view suggested by F. Otto Schrader above? Could the audience 
of the Buddha have thought that an expiring flame does not really go out but goes back into a non-manifested state as latent heat?

In order to answer this question, we may need to look at some passages in the Upanișads suggested by F. Otto Schrader in his article 'On the Problem of Nirvāna' ${ }^{52}$ Apart from the passages mentioned above, ${ }^{53}$ one passage in the Śvetâsvatara Upanișad seems to show where this Indian view could have originated. It reads as follows:

When a fire is contained within its womb (yoni), one cannot see its visible form and yet its essential character (linga) is not extinguished; one can grasp the fire once again from its womb by means of tinder. In just the same way, one can grasp both within the body by means of the syllable OM. ${ }^{54}$

According to Olivelle, ${ }^{55}$ the image here is the production of fire by using a fire-drill. In the fire-drill method, a stick is rotated rapidly in a pit in a stationary piece of wood to produce a fire. The womb (yoni) here is the depression on the lower slab into which the drill is inserted and then twirled to produce fire.

Thus, the essential character (linga $)^{56}$ of a fire is believed not to be extinguished but to be hidden in the depression on the lower slab. That is to say, this imperishable essential character could be the origin of the common Indian view in which people think of an extinct fire not as having gone to nothing but as having returned to its origin or pure state. However, there are some problems with accepting that this notion of the imperishable essential character (linga) behind a phenomenal fire is already presupposed in the metaphor of a fire extinguished in the context of nirvana without a remainder of clinging (anupadhiśeșanirvānadhātu).

This essential character is something ready to produce a fire in the future when suitable conditions, such as tinder and friction, are given. As long as it can be made to reappear easily in the future it could not be the image of a fire extinguished in the context of nirvana without a remainder of clinging, where the most important message to be conveyed is that it will never reappear. Moreover, the notion of this imperishable essential character behind a phenomenal fire is absent from the description of the fire-drill in the one of the oldest Upanișads, the Bṛhadäranyaka Upanișad, which probably predates Buddhism. It reads as follows: 'Then he churned like this and, using his hands, produced fire from his mouth as from a vagina. As a result the inner sides of both these - the hands and the mouth - are without hair, for the inside of the vagina is without hair. ${ }^{57}$ 'Churned like this' is, according to Olivelle, ${ }^{58}$ a good example of the oral nature of the Upanisads. What it meant could be the reciter's demonstration of the fire-drill by churning with his palms to make friction and then by blowing with his mouth to produce a fire blaze. 
Unlike the passage in the Śvetâśvatara Upanisad in which the idea of the imperishable character behind a phenomenal fire is expressed, this passage seems to focus on the creation of a fire, as the whole passage is dealing with Brahman's super-creation. In fact, the production of fire by this fire-drill method has sexual connotations: the depression on the slab is often compared to a vagina, or a womb, and the churning stick to a penis. Although this reciter's demonstration of the fire-drill began to be used as a metaphor in the Brhadāranyaka Upanișad, there seems to be no idea of an eternal character behind a phenomenal fire at this stage.

The notion of the imperishable essential character behind a phenomenal fire seems to be influenced by the notion of a self (ätman), which is allpervading and is contained in our body. Since it is the main message of the Upanișads, the relationship between the phenomenal body and the self is expressed through various images, such as salt in brine. Later in the Śvetâśvatara Upanișad, fire in fire-drills was compared to oil in sesame seeds, butter in curds and water in a river-bed ${ }^{59}$ all of which are used to explain the self (ätman) behind phenomena.

In my opinion, the Buddha probably knew this notion of a self (ätman) behind the Upanișadic image of a fire extinguished. Since accepting self was against one of the basic principles of his thought, the principle of no-self (anātman), the Buddha perhaps was precisely arguing against this kind of view by using it slightly differently.

By replying to Vacchagotta's question, 'This fire that has gone out in front of you, in which direction - to the east, west, north or south - has it gone from here?', not only did the Buddha maintain his own way of thinking, thinking according to the cause (yoniso manasikāra), but he also reacted against this notion to show how irrelevant this view was. Assuming a state like a soul is outside the range of his methodology and the best thing we can do is just leave it aside.

\section{The Theravāda exegetical position on nirvana}

We have seen that the fire image when used for nirvana without a remainder of clinging was a fire's going out through lack of fuel. Although most suttas explain this final stage in this way, ${ }^{60}$ there is one sutta in the Pārayanavagga in the Suttanipäta that explains the extinction of a fire in a different way. There is no Chinese equivalent of this text, yet its antiquity cannot be doubted. Not only is it mentioned in the Vinay ${ }^{61}$ but more than half the suttas in this text also have correspondents in Sanskrit and Prākrit. ${ }^{62}$ The Pārāyanavagga seems to have been known among Buddhists in mainland India not as one of the traditional sütras, but as one of the collections of chanted verses.

According to Lamotte, 'there are clearly ancient compositions of considerable poetic value which use stanzas as a means of expression. The Buddha was not responsible for composing them and they do not develop the 
profound meaning associated with the doctrine of emptiness. ${ }^{63}$ The name Pārāyana, among other names, such as Dharmapada and Arthavarga, was nearly always found in lists of such works ${ }^{64}$ and this could be the reason why Northern Buddhists hesitated to form a definitive collection of this kind, as the Theravādins did in their Pali Khuddakanikāya. That is to say, its authenticity was not universally accepted among early Indian Buddhists.

\section{The Pārāyana stanza in the Suttanipāta}

The text of the Pārāyanavagga was about a kind of question time offered by the Buddha to fifteen young brahmans who were pupils of a renowned Brahman, Bāvari. When Upasīva, one of the young Brahmans, asked the Buddha about the last consciousness of an enlightened one at the final stage, the Buddha answered as follows: "Just as a flame is tossed about by the force of the wind, Upasiva", said the blessed one, "goes out and no longer counts (as a flame), so a sage released from his mental body goes out and no longer counts (as a sage)" ${ }^{65}$ Steven Collins has translated 'mental body' (nāmakāya) as 'name-and-form' in his book Nirvana and Other Buddhist Felicities, ${ }^{66}$ so that it is synonymous with namarūpa, psycho-physical phenomena ${ }^{67} \mathrm{He}$ seems to translate it as a coordinate (dvandva) compound, thinking that, as long as it is the final release, it should be the release of an enlightened not only from his mental category but also from his physical category.

Within the early Pali canon, this compound was generally regarded as a descriptive (karmadhāraya) compound meaning 'mental category' as contrasted with 'physical category' (rüpakāya) in explaining the relationship between nāmarūpa and contact (phassa) in dependent origination (paticcasamuppāda). ${ }^{68}$ 'Mental body' here seems to mean the category of name (näma). To be released from the category of name is the same as being released from the category of what is nameable. So this refers to the same as na upeti samkham: when a saint dies he cannot be referred to by language or conceptionalised. According to the Cullaniddesa, an enlightened one at this stage was already released from his physical category and about to be released from his mental category. The commentary explains this in the following way: 'released from the category of name means the sage who, already, released from the category of form was eliminated by the abandonment through the opposite, through passing beyond and through repression' ${ }^{69}$ That is to say, the Theravāda tradition regards this verse as explaining the final release of an enlightened one who has already been released from his physical aspect by meditation. ${ }^{70}$ This verse thus explains nirvana without a remainder of clinging through the image of a fire extinguished by the force of the wind.

However, this fire image could be quite different from the fire image used in the context of the last unanswered question. As we have seen above, a fire in that context goes out through lack of fuel. ${ }^{71}$ In order to explain nirvana 
without a remainder of clinging (anupādisesanibbānadhātu), it should explain why a fire will not reappear in the future, like the image of a fire's going out through lack of fuel seen above. ${ }^{72}$ If a fire is extinguished by the force of the wind, it could easily reappear in the future when suitable conditions, such as tinder or friction, are given to the remaining fuel, such as oil or firewood. That is to say, this image could not be enough to explain why this particular extinction of a fire should be regarded as the final one.

Moreover, this image could fit the fire image in the later Upanisads, in which fire's imperishable essential character (linga) is contained within its womb, ready to reappear by means of tinder. ${ }^{73}$ Earlier in this chapter, I showed that this could be the source of the common Indian view on the quenching of a fire: 'an expiring flame does not really go out, but returns into the primitive, pure, invisible state of fire it had before its appearance as visible fire'. ${ }^{74}$

Although this image, 'a flame is tossed about by the force of the wind', looks as if it is following the basic etymological meaning of nirvana, 'going out' (nir $\sqrt{ } v \bar{a}$ (to blow)), ${ }^{75}$ its implication when used in the context of nirvana without a remainder of clinging (anupādisesanibbānadhātu) could be quite unexpected. Whether it is intended or not, this fire image in the Parrayanavagga seems to open the way to interpreting the state of an enlightened one after death not simply as mere non-existence.

In fact, there is another clue in this verse that could be used to interpret this state as something existing separately (pätiyekka). Instead of saying there is no more rebirth in the future, as in the context of the last unanswered question, it says 'a sage released from his mental body goes out (attham paleti) and no longer counts (as a sage)'.

According to PED, attham paleti is synonymous with attham gacchati, which usually appears as the noun atthangama in the early canon and as the participle atthangata in the Jätaka. Although the former, atthangama, generally meant 'annihilation, disappearance' as opposed to samudaya and synonymous with nirodha, the latter, atthangata, was used together with suriya to refer to the setting of the sun. As I show later in this chapter, this latter meaning seems to open the way to interpreting the state of an enlightened one after death as something existing separately (pätiyekka).

The Sanskrit equivalent of the word attha is asta, meaning 'home, the western mountain (behind which the sun is supposed to set)' ${ }^{76}$ Attha in this meaning is found not only in the Jätaka but also in the Anguttaranikāya ${ }^{77}$ together with the verb eti derived from the root $\sqrt{ }_{i}$ (to go). Thus, the literal meaning of attham paleti could be 'going home to its resting place'. If we apply this meaning to this Pärāyana verse, it could mean that an enlightened person when finally released does not go to nothing but goes to somewhere, like home or the western mountain, as a kind of resting place.

Within the Theravāda exegetical tradition, this verse seems to be used for the two of the crucial interpretations that could almost determine what the 
final nirvana may be. While the image of a fire tossed about by the force of the wind was used to interpret the verse believed to have been uttered by Anuruddha at the time of the Buddha's final release at Kuśinagara, the literal meaning of attham paleti seems to be used as a secret weapon against disputants (vitandavādins) who insist that nirvana is mere destruction $\left(\right.$ khayamatta) ${ }^{78}$

First, this verse was added at the end of the clarification in which Anuruddha's verse was initially interpreted as the image of a fire's going out through lack of fuel. The interpretation of Anuruddha's verse became a kind of battleground between the Sarvāstivāda and the Sautrāntika on the ontological issue of nirvana. ${ }^{79}$ The Theravādins seem to step aside from this battle, yet they still needed to establish their own position on this issue.

According to the Mahāparinibbānasuttanta in the Dighanikāya, Anuruddha uttered a verse when the Buddha was finally released at Kuśinagara:

There was no sign of breathing in or out of such a one whose mind is stable. The sighted one who is free from desire and has attained peace has passed away. He with mind free from attachment bore his pain. His mind was liberated like the going out of a lamp. ${ }^{80}$

The last stanza was among the most famous and was quoted, though slightly differently, even within two suttas in the Anguttara-nikāya. ${ }^{81}$ Within the Theravāda exegetical tradition, this last stanza was interpreted expansively in the Theragāthāațthakathā:

'His mind was liberated like the going out of a lamp': as a lamp or a lantern which is burning on account of oil and wick is extinguished when these give out, and when extinguished does not continue after going anywhere else but on the contrary disappears and becomes invisible, in that way the series of aggregates which continues by means of the operation of defilements is extinguished when they give out, and when extinguished does not continue after going anywhere else but on the contrary disappears and becomes invisible. Therefore it is said that 'the steadfast are extinguished like this lamp' and as a flame is tossed about by the force of the winds and the like. ${ }^{82}$

Within the early canon, the cause of a fire's extinction was not considered critically. This metaphor was not as specific, and in any language it is presumably possible to say that a fire is extinguished without specifying the cause. The word nibbanna is grammatically intransitive. It originally meant the going out of a smith's fire when a smith stops blowing a wind on it. As suggested by Ñyānamoḷi, it was later extended to 'extinction of a fire by any means, ${ }^{83}$ 
Apart from the above mentioned Pärāyana stanza, this exegesis also quoted a stanza from the Khuddakapătha saying 'the steadfast are extinguished like this lamp'. ${ }^{84}$ Like Anuruddha's stanza, it did not mention the cause of this lamp's going out. It could go out either through the power of the wind, as in the Päräyana stanza, or through the lack of fuel such as oil and wick, as in the dialogue between the Buddha and Vacchagotta. Its commentary simply said, 'It seems, one lamp among those that had been lit to honor the city deities on that occasion, actually went out, and it was with reference to that that he said "like this lamp". ${ }^{85}$

The Pärayana stanza was quoted, or could be added, at the end of the explanation in which the going out of a lamp was initially explained through lack of oil and wick. Whether a fire goes out through the power of the wind or through the lack of fuel, both cases can explain what happens when a fire goes out, yet their implications for ontology could be, as seen above ${ }^{86}$ somewhat different.

If the Theravādins used this stanza, disregarding their dissimilarity, there must be a reason why they did so: they probably wanted to open the possibility of interpreting nirvana not as mere non-existence. This could be closely related to the doctrinal development of nirvana within the Theravāda abhidhamma together with an attempt to fill the silence of the Buddha.

\section{Nirvana and space in the Pali abhidhamma}

In Chapter 3, in the section titled 'The Pali abhidhamma works', we saw that the word nirvana was hardly mentioned in the Pali abhidhamma and the word unconditioned (asankhata) was used instead. Within this abhidhamma, nirvana was established as the one and only unconditioned. ${ }^{87}$ It also is said to be the only thing that does not belong to the five aggregates (skandha) ${ }^{88}$ yet belongs both to the sphere of mental data base (dhammāyatana) in the twelve spheres classification ${ }^{89}$ and to the element of mental data base (dhammadhātu) in the eighteen elements classification. ${ }^{90}$

Apart from the number of unconditioned things, ${ }^{91}$ there was no conflict between the Theravāda abhidhamma and the Sarvāstivāda abhidharma. ${ }^{92}$ This unusual conformity suggests that the underlying position on nirvana may have been established at the early stage of the abhidharma literature before the separation of the Sarvāstivādins and the Vibhajyavādins. ${ }^{93}$ In fact, it seems to be the starting point of the extensive and convoluted doctrinal developments on nirvana in Buddhist schools, since there clearly is a problem here.

This puzzling classification of nirvana seems to be established along with the two nirvana theory seen in Chapter 2. Nirvana cannot be classed under the five aggregates since nirvana without a remainder of clinging (anupādisesanibbāna-dhätu) was the cessation of the aggregates. ${ }^{94}$ By contrast, nirvana can be classified under mental data base (dharma) both in the 
twelve spheres classification and in the eighteen elements classification, since it is an object of thought, or more explicitly a name given to the experience of being without the triple fires of passion, hatred and delusion that was realised by the Buddha at the moment of enlightenment; that is to say, at the moment of nirvana with a remainder of clinging (sopādisesanibbānadhātu). ${ }^{95}$ Although this observation can make sense separately it cannot make sense when these three classifications are integrated.

Early Buddhists, especially the masters of the abhidharma, were busy at classifying psycho-physical phenomena. Classification requires a hierarchy of categories and the five aggregates (skandha), the twelve spheres (äyatana) and the eighteen elements (dhätu) are among the basics. Since these three were seen frequently in the early canon and sub-categories of them overlapped extensively, they started to explain how a certain sub-category in a category corresponds to sub-categories in other categories.

The mental data base (dhamma) in both the twelve spheres (äyatana) and the eighteen elements (dhātu), for example, corresponds to feeling (vedanā), apperception (samjñā) and volitional activities (samskāra) in the five aggregates. These correspondences are illustrated in Table 4.1.

The obvious dilemma that the masters of the abhidharma faced was placing nirvana without breaking the parallelism between sub-categories shown in Table 4.1. They could not simply place it under the mental data base (dharma) in the twelve ayatanas and the eighteen dhätu, since that would make nirvana automatically correspond to feeling (vedana $)$, apperception

Table 4.1 Five skandha, twelve āyatana and eighteen dhätu

\begin{tabular}{|c|c|c|c|}
\hline \multirow{2}{*}{ Five skandha } & \multicolumn{3}{|c|}{ Eighteen dhātu } \\
\hline & \multicolumn{2}{|c|}{ Twelve āyatana } & \\
\hline \multirow{5}{*}{ rūpa } & rūpa & cakșus & \multirow{5}{*}{$\begin{array}{c}\text { cakșurvijñāna } \\
\text { śrotravijñāna } \\
\text { ghrānavijñāna } \\
\text { jihvāvijñāna } \\
\text { kāyavijñāna }\end{array}$} \\
\hline & śabda & śrotra & \\
\hline & gandha & ghrāṇa & \\
\hline & rasa & $j i h v \bar{a}$ & \\
\hline & spraștavya & $k \bar{a} y a$ & \\
\hline vedanā & \multirow{3}{*}{ dharma } & \multirow{4}{*}{ manas } & \multirow{4}{*}{ manovijñāna } \\
\hline samjiña & & & \\
\hline sampskāra & & & \\
\hline vijñ̄āna & & & \\
\hline
\end{tabular}

Sources: based on Nārada (1977: 27) and Kachiyama (1988: 28). 
( $\operatorname{samjña}$ ) or volitional activities (samskāra) in the five skandha. Placing it under the five skandhas also causes difficulty, because nirvana is said to be wholly different from them. In either case, there must be an explanation for how it is possible. This seems to cause tremendous difficulties among early Buddhist schools and each came up with its own solution to this dilemma.

The Sarvāstivādins ${ }^{96}$ for example, seemed to stop puzzling over this predicament, and as a solution they introduced a new and more comprehensive category called pañcavastuka: the five categories of rūpa, mind (citta), mental states (caitta), states not associated with mind (cittaviprayukta), and the unconditioned (asamskrta), which all together made up seventy-five dharma. ${ }^{97}$

The Sautrāntikas, who stressed the value of the early canon (sütra) against the abhidharma, were obviously against this new category of the Sarvāstivādins, since they could not find it in the early canon (sūtra). Vasubandhu seems to leave this dilemma unsolved in the first chapter of his Abhidharmakośabhāsya.$^{98} \mathrm{He}$ gave three explanations why unconditioned things should not be classed under the five aggregates, yet did not give an answer to the crucial question: how could unconditioned things form part of dharmàyatana and dharmadhātu while at the same time not forming part of the skandha.

Instead, he mentioned one opinion that insisted that unconditioned things could be neither àyatana nor dhātu from the simple reasoning: 'Just as the end of a pot is not a pot, so the end of aggregates is not aggregates'. ${ }^{99}$ By the same reasoning, the end of spheres is not a sphere and the end of elements is not an element. In fact this simile was initially presented by the Sarvāstivādins in the Mahävibhāsasaśastra as one of the ten reasons why unconditioned things cannot be under the skandhas. ${ }^{100}$ This suggests that there were discrepancies even among the Sarvāstivādins, despite their introduction of the new category. By mentioning this opinion Vasubandhu seemed to enjoy this internal conflict, since he, as a Sautrāntika, was not obliged to solve this predicament, a kind of side effect caused by abhidharma classification.

What was the Theravādins' solution to this dilemma? One simple answer could be their later introduction of a new category that consists of four fundamentals: rüpa, mental states (cetasika), mind (citta) and the unconditioned (asañkata), which all together are made up of eighty-two dhamma. ${ }^{101}$ But how did they deal with it earlier in the abhidhamma period?

L. S. Cousins in his article 'Nibbāna and Abhidhamma' has suggested that the unconditioned could be placed under nāma, a name given to the four mental aggregates. Based on the clarification given in the Dhammasangani, the first book of the Pali abhidhamma, he explains this as follows:

The unconditioned is not matter, although like matter it is inactive from a kammic point of view and does not depend upon an object as a reference point. It is not any kind of mental event or activity nor is it the consciousness which is aware of mind and matter, 
although it can be compared in certain respects with the mentality of the paths and fruits. The Dhammasangani often classifies paths, fruits and the unconditioned together as 'the unincluded (apariyāpanna)', i.e. not included in the three levels. Later tradition refers to this as the nine supramundane dhammas. The unincluded consciousness, unincluded mental activities and unconditioned element are alike in that they are not able to associate with upādāna or with any kind of torment (kilesa), they are all 'immeasurable' and they are all 'refined'. The unconditioned element is unique in that it is not classifiable in terms of arising or as past, present or future. Suggestively, however, it may be reckoned as nāma rather than rūpa. ${ }^{102}$

The Dhammasangani does explicitly class the unconditioned element along with the four mental aggregates under the name namma. ${ }^{103}$ Whether this was intended or not, it could have solved the above mentioned dilemma by putting it under one of the three traditional correspondents of the mental data base (dhamma): feeling (vedana $)$, apperception (samjñ $\bar{a})$ and volitional activities (samskāra). However, this is clearly contradicted by the Dhammasangani's earlier observation that the unconditioned element as "without condition' (appaccaya) is different from the five aggregates as 'with condition' (sappaccaya). ${ }^{104}$ This solution seems to be ignored in the third book of the Pali abhidhamma, the Dhätukathä, which explicitly and frequently points out that 'the unconditioned is not classified as an aggregate'. ${ }^{105}$

The contribution of the Vibhanga, the second book of the abhidhamma, on nirvana was, apart from its placement of the unconditioned under the sphere of mental data base (dhammäyatana) ${ }^{106}$ and under the element of mental data base (dhammadhātu), ${ }^{107}$ to establish a basic definition of nirvana: 'What is the unconditioned element? It is the cessation of passion, the cessation of hatred and the cessation of delusion. ${ }^{108}$ This definition is not without textual evidence. It is quoted from a dialogue on nirvana between Sāriputta and the wanderer Jambukhādaka in the Nibbānasutta. ${ }^{109}$ The same answer was also given to the question about being sainthood (arahant) ${ }^{110}$ in the next sutta. Although I discuss both suttas later in relation to the literal meaning of attham paleti, this latter sutta was actually used as textual evidence for the Theravādins against disputants (vitandavādins) who insist that nirvana is mere destruction (khayamatta) on the basis of the Nibbānasutta's dialogue.

This definition seems to reflect early Buddhist trends to put more weight on nirvana in this life than on nirvana after death. As I have shown in Chapter 2, nirvana is a name given to the experience of being without passion, hatred and delusion and is realised at the moment of enlightenment. For an enlightened one, his final liberation, anupādisesa nibbānadhātu, is already confirmed at the moment of the enlightenment, saupādisesa nibbānadhätu. ${ }^{111}$

Since we can talk about it conceptually it can be included among the mental data (dhamma) in both categories. This definition and classification 
of the unconditioned element given in the Vibhanga was so solid and widely accepted in their tradition that the Theravādins seem to have had no choice, unlike the Abhidharmakośabhāsya seen above, ${ }^{112}$ but to find an explanation of how it could be classified as an àyatana and dhätu. We can find a small clue in the fifth book of this abhidhamma, the Kathāvatthu.

In Chapter 3 we saw that it is the 'singularity' of the unconditioned (asamskrta) that Pali abhidhamma seeks to establish for nirvana. The Kathāvatthu was the book that established this aim and rejected plurality of the unconditioned. The decisive argument put forward from the Theravādins was as follows: 'Of the two nibbänas, is one high one low, one excellent one deficient, one superior one inferior, and is there a boundary or difference, a line or interval between them?"113 This argument is unique in the Theravāda. The question is: where does this unique argument come from? André Bareau pointed out that the Theravāda's basic concept of nirvana came from the structure of space. ${ }^{114} \mathrm{He}$ did not mean that this space was 'smaller space', or physical space, through which we arrive at the concept of nothingness. None the less, he insisted that the concept of space can be found at the bottom of the Buddhist concept of nirvana. ${ }^{15}$

L. S. Cousins has suggested that the argument put forward in the Kathävatthu is more subtle and is a reductio ad absurdum. Here is his reconstruction of the above passage with modern terminology:

The unconditioned is by definition not in any temporal or spatial relation to anything. Qualitatively it is superior to everything. If then two unconditioneds are posited, two refutations are possible. Firstly, either only one of them is superior to everything and the other inferior to that one or both are identical in quality. Obviously if one is superior then only that one is unconditioned. Secondly, for there to be two unconditioneds, there must be some dividing line or distinguishing feature. If there is, then neither would be unconditioned since such a division or dividing line would automatically bring both into the relative realm of the conditioned. Of course if there is no distinguishing feature and they are identical in quality, it is ridiculous to talk of two unconditioneds. ${ }^{116}$

$\mathrm{He}$ is probably right to separate the concept of space from this argument. $\mathrm{He}$, unlike André Bareau, may want to avoid one obvious outcome of this Kathāvatthu passage: that the Theravāda's concept of nirvana was derived from the concept of space. This must be an unwanted result not only for him but also for the masters of the Pali abhidhamma. They clearly rejected the view that space $(\bar{a} k \bar{a} s a)$, among other things such as dependent origination (paticcasamuppāda), can be the unconditioned. ${ }^{117}$

The space $(\bar{a} k \bar{a} s a)$ rejected here is the space element ( $\bar{a} k \bar{a} s a d h \bar{a} t u)$ seen in the Dhammasangani and the Vibhanga ${ }^{118}$ According to the Dhammasangani, 
the space element is rupa; this is space, atmosphere, cavity, hole, aperture, gap and what is not touched by the four secondary elements (asamphuțtham catūhi mahäbhütehi). ${ }^{119}$ Later, in the Vibhanga, space was further classified into external (bāhira) and internal (ajjhattika), with the latter defined as rüpa, which is space, atmosphere, cavity, hole, aperture, gap and what is not touched by flesh or blood (asamphuttham mamsalohitehi), such as a cavity of the ear or the nose. ${ }^{120}$

Although Karunadasa has made a comprehensive analysis of the Theravādins' idea of matter, his remarks on space are not quite satisfactory. He has attempted to identify the above internal and external division of space with the Sarvāstivādins' two kind of space: space ( $\bar{a} k \bar{a} s \dot{s} a)$ as an unconditioned thing and space element (ākāśadhātu) under form (rūpa).

He seems to ignore the fact that the former, $\bar{a} k \bar{a} s a^{\prime}$, for the Sarvāstivāda is a real existent (dravya) that by definition (svabhāva) does not obstruct (anāvarana) ${ }^{121}$ while the latter, ākāśadhātu, is just a name given to cavity (chidra) ${ }_{1}^{122}$ which is visible matter since it is form (rüpa) next to other visible matter. ${ }^{123}$ For example, we can see space between walls because there are space elements at the end of, or next to, the visible secondary matter that forms each visible wall. One thing common to both is that it is something that occupies what we conventionally call space.

By contrast, the space element in the Dhammasangani is by definition quite the opposite: it is what is not touched by the four secondary elements (asamphuțtham catūhi mahābhūtehi). Although the Vibhanga further divided it into internal and external, they are virtually the same. The internal is by definition absorbed into the external since flesh and blood are made up of secondary elements. In this respect, his assigning the space element, especially the internal space element, to the secondary elements (upādārupa) was a bit far fetched. It was based on the fact that the space element is dependent on them. In fact, the opposite is also quite possible. Although space is classed under form (rupa) owing to its close relationship with the element, it designates space where there is no secondary element at all. From another debate in the Kathavvatthu, we can actually see this is the case of the Theravādins.

As an argument against the idea that space is visible, the Kathävatthu asks if it is possible to say that 'with the visual faculty and space as condition, visual consciousness arises'; are there any suttas that have said that? ${ }^{124}$ What is meant here is that when we see space, what has arisen is not visual consciousness (cakkhuviññana) but mental consciousness (manoviññanna).

Later in its commentary, this was reckoned as mind-door consciousness (manodvāraviññanna) under the influence of the Theravādin's unique fourteen activities of consciousness (viññannakicca) ${ }^{125}$ For example, when we see space between walls, our recognition of space results from the mental image of two walls we have just seen. Although there is no rüpa between the walls, the cavity between them can be known through the mind. This could further 
suggest that, since our recognition of space is not visual consciousness but mental consciousness, there must be a corresponding idea of space inside our cognition, or more precisely in our mental data base. When we see sky, for example, we cannot see its infinity visually yet we can imagine it mentally. Thus, space for the Theravādins could have two distinctive characters: space from a physical perspective does not exist, yet can be classified as rüpa skandha as its initial cause; space from a mental perspective exists as the idea of space in the mental data base in both the twelve spheres (äyatana) and the eighteen elements $(d h \bar{a} t u)$. While the former seems to be rejected as the unconditioned in the Kathâvatthu, ${ }^{126}$ the latter in an absolute sense seems to be utilised, together with the mystique tendency of the Theravādins, ${ }^{127}$ to establish their unique argument for the one and only unconditioned.

How does this double aspect of space ( $\left.\bar{a} k \bar{a} s{ }^{\prime} a\right)$ relate to the effort to solve the above mentioned abhidhamma predicament. This double aspect of space $(\bar{a} k \bar{a} s \dot{a} a)$ seen in the Kathāvatthu could give us a vital clue to understand how the Theravādins avoid this predicament. Although nirvana for them was the one and only unconditioned, space was regarded as something very close to the unconditioned. In the Milindapañha, space was, together with nirvana, regarded as one of the two dhammas that are born neither of action

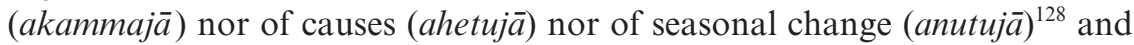
was described as infinite (ananto), boundless (appamāno) and immeasurable (aparimeyyo). ${ }^{129}$ In other words, space could at least have some qualities of the unconditioned.

Just as space is classed under rupa skandha owing to its close relationship with them, whereas it actually designates the place where there is no secondary matter at all, so nirvana can be said to have a close relationship with the skandha, whereas it actually designates the state where there are no skandha at all. Our recognition of both space and nirvana comes inwardly from their elements in the dharmāyatana and the dharmadhätu. This could be one of the reasons why the mental aspect of space underlies the Theravādins' unique argument concerning nirvana.

\section{Influence of the Buddhist theory of momentariness}

While the Theravādins maintained this unique position on the unconditioned, Northern Buddhists accepted a number of dharmas as unconditioned things that include their equivalent of nirvana: extinction through knowledge ( pratisamkhyānirodha). ${ }^{130}$ Apart from the Theravādins, the Vātsīputrīyas are the only school that insisted that nirvana was the one and only unconditioned. Most schools accepted this new concept and according to the Mahāvibhāsăsaśastra the Vibhajyavādins, ${ }^{131}$ presumably the northern counterparts of the southern Theravādins, were one of them. ${ }^{132}$

It is not clear whether the Vibhajyavāda mentioned in the Chinese abhidharma traditions is the same school as the Theravāda, ${ }^{133}$ yet it is still 
possible to say that all Theravādins are Vibhajyavādins but not necessarily vice versa. The Vibhajyavādins at least share the same ideology against the Sarvāstivādins who insisted on the existence of all dharmas in the three time periods. As their name suggests, they made a distinction between dharmas and then said that some exist while some do not. The best description to explain their position is in the Abhidharmakośabhāsya:

Those who affirm the existence of past, future and present are regarded as the Sarvāstivādins. Those who affirm the existence of the present and a part of the past, namely the existence of action that has not given forth its result, and the non-existence of the future and a part of the past, namely the non-existence of action that has given forth its result, are regarded as the Vibhajyavādin. ${ }^{134}$

This difference, according to the Theravāda traditions, could have played a major role in the great separation during the period of King Ashoka. ${ }^{135}$ For the Vibhajyavādin all dharmas will eventually pass into non-existence, since existing past action, when it has produced its result, will become nonexistent. That is to say, there is no need for nirvana to exist in the three time periods to works as a deterrent, or an antidote (pratipakșa), as for the Sarvāstivādins seen above. ${ }^{136}$

The name Vibhajyavādins (分別論者) in the Mahāvibhāsāsisastra, the extensive commentary on the last book of the Chinese abhidharma, the Jñannaprasthāna, is a bit obscure. It is not yet clear whether this name refers to a historical school or a generic term for their methodology. The latter possibility seems to be unlikely since a different term was used in this treatise: an analytic interpretation (分別説). In the Mahāvibhāsāaśästra, detailed, separate, analytic, progressive methodologies were sometimes contrasted with brief, comprehensive, non-analytic, simultaneous methodologies. ${ }^{137}$

What cannot be ignored is the fact that the fen-bie-lun-zhe (分別論者), which is the Chinese word for the Vibhajyavādins, and was used frequently in the Mahāvibhasșassástra, was actually different form the translation of the word Vibhajyavādin (分別説部, fen-bie-shuo-bu) appearing in Xuan-zang's translation of the Abhidharmakośabhāsya. He translated both treatises and the Chinese word applied to the Vibhajyavādin in the Abhidharmakośabhāṣya was not the fen-bie-lun-zhe but the fen-bie-shuo-bu. ${ }^{138}$

In fact, the latter term appeared only once in the Mahāvibhāṣāsástra, where the nature of the three karmas, bodily, verbal and conscious actions, is discussed. ${ }^{139}$ While the Sautrāntikas insisted that they are by nature intention (cetanā), the Vibhajyavādin maintained that the nature of karmas is passion, hatred and delusion. This seems to suggest that the term Vibhajyavādin could be used in a narrow sense to refer to an early historical school who contested against the Sarvāstivādins, while the term could be used in a broad sense to refer to schools including the Vibhajyavādin that are 
against the existence of all dharmas in the three time periods through their distinctive methodology, especially that of making distinctions between dharmas. This could be the reason why doctrines attributed to the Vibhajyavādins are agreed to by many ancient schools, such as the Mahāsānghikas and the Mahīsāsakas, yet none of them agree with the Sarvāstivādins. ${ }^{140}$

The doctrines attributed to the Vibhajyavādins, especially concerning the unconditioned things, overlapped extensively with the Mahāsānghika list of unconditioned things. They accepted dependent origination ( pratītyasamutpāda) ${ }^{141}$ the way (mārga) ${ }^{142}$ and the characteristic of conditioned things (svalaksana), ${ }^{143}$ together with the extinction through knowledge (pratisamkhyānirodha) and extinction without knowledge (apratisaṃhyānirodha). ${ }^{144}$

In the Mahāvibhāsāśāastra, the difference between the Sarvāstivādins, the Sautrāntikas and the Vibhajyavādins on the last three dharmas was explained as follows: ${ }^{145}$

This is in order to refute other systems and to clarify the correct opinion [of the Vaibhāșikas]. In other words, one wrong view, that of the Dārștanntikas, holds that extinction through knowledge (pratisamkhyānirodha), extinction without knowledge (apratisamkhyānirodha), and extinction as impermanence (anityatänirodha $)^{146}$ are not real existents (dravya). In order to refute this opinion the author makes clear that all three extinctions are real existents. Another wrong view, that of the Vibhajyavādins, holds that all three extinctions are the unconditioned (asamskrta). In order to refute this opinion the author makes clear that while the first two are unconditioned things (asamskrta), the last, extinction as impermanence, is a conditioned thing (samskrta).

Here, the Vaibhāṣika was the name given to a group of the Sarvāstivādins who were involved in composing and maintaining this vast treatise, the Mahāvibhāṣāśāstra. The difference between the Dārșțāntikas and the Sautrāntikas according to the Chinese tradition was chronological, the earlier term Dārșțāntikas being replaced by the term Sautrāntikas in the later period. ${ }^{147}$ This view is, however, contested by the view that they simply represent different perspectives from which the same group can be seen: the Dārștāntikas has a negative connotation and is used by opponents, such as the Kāśmīra Sarvāstivādins, to suggest the group's reliance upon the invalid authority of conventional examples; the term Sautrāntikas has a positive connotation and is used by the group itself to refer to its own views. ${ }^{148}$

What could be the reason why many Buddhist schools accepted a new concept, extinction through knowledge (pratisamkhyānirodha)? The doctrinal development of the Buddhist theory of momentariness seems to be the reason 
for this abhidharmic introduction of it among Northern Buddhists. This new development seems to cause the later conceptual change of the word nirodha (extinction). We need to see briefly how this abhidharmic system, which became dominant among Northern Buddhist schools, works in the Sarvāstivāda.

The Sarvāstivādins on the one hand insist on the existence of all dharmas in the three time periods, while on the other hand they accept the momentariness of conditioned dharmas. What changes momentarily is not the intrinsic nature (svabhāva) of a dharma but its activities - arising, duration, decay and ceasing - through its inherent characteristic (svalaksana) of impermanence. As long as a conditioned dharma is connected to the series of aggregates through an acquisition (prāpti), it renews its four activities until the connection is finally cut. This continual ceasing is one of four characteristics of impermanent conditioned (samskrta) dharmas and is technically called extinction as impermanence (anityatānirodha).

Whereas for the Sautrāntikas all three extinctions are not real existents, for the Vibhajyavādins they are unconditioned things. Later in the Mahāvibhāsậsáastra, the Vibhajyavādins insisted that if the nature of four characteristics is a conditioned thing, it could be too weak to continue its four activities. ${ }^{149}$ For the Sarvāstivādins, this repeated extinction was different from the two unconditioned extinctions: extinction without knowledge (apratisamkhyānirodha) and extinction through knowledge (pratisamkhyanirodha). For them the former is the perpetual non-existence of the future dharmas within a series of aggregates, while the latter is the perpetual separation of an impure dharma from a series of aggregates through the antidote, 'acquisition of disjunction' (visamyogaprāpti). ${ }^{150}$

This latter extinction is the Sarvāstivādins' equivalent of nirvana and is paradoxically not an eventual extinction or non-existence of a dharma but an acquisition of a dharma, technically 'the acquisition of disjunction' (visamyogaprāpti). Since all dharmas exist for the three time periods, this dharma that arises from knowledge (pratisamkhya $)$ works as an antidote (pratipaksa) to prevent henceforward any connection between defilement and this series.

Thus, the Sarvāstivādins should explain how extinction could in reality have the opposite meaning. The Sarvāstivādins seem to use the genitive case to solve this paradox. ${ }^{151}$ The position of the Sarvāstivāda was explained in the Abhidharmakośabhāsya in the following way: 'The cessation (nirodha) which is acquired through the cutting of the acquisition of a defilement, even in another existence, is designated as "of that [thing]". ${ }^{152}$ We can see a similar explanation of the Sarvāstivādins in the Nyāyānusāraśăstra ${ }^{153}$ and in the Prasannapada.${ }^{154}$ What has been explained here is that nirodha is only a name given to a dharma that consists of the non-existence (abhäva) of something. As long as it is the final extinction of a dharma, it should mean that 
the end of its activities - arising, duration, decay and ceasing - within its series. That is to say, it could be achieved not by its inherent continuous extinction but by non-arising or non-existence of that dharma within its series.

We can see almost the same approach to the word nirodha in one of the best known treatises of the Theravādins, the Visuddhimagga: 'But it is because the kind of destruction called "cessation consisting in non-arising" [that is, nibbāna] serves figuratively speaking as decisive support [for the path] that [nibbāna] is called "destruction" as a metaphor for it." ${ }^{\text {"155 }}$ One could blame Buddhaghosa, a northerner, for introducing this into the Theravāda. In fact, the expression 'cessation consisting in non-arising' (anuppattinirodha) was not seen earlier in the Theravāda tradition and is confined to quite late materials. This could suggest that the Theravādins accepted the Buddhist theory of momentariness in a fully developed form later than the Northern Buddhist schools.

Under the influence of the Buddhist theory of momentariness, the Theravāda concept of nirvana seems to have changed: it is the cessation consisting in non-arising and exists separately (pätiyekka) from the mere destruction of passion, hatred and delusion. Although nirvana for them is the one and only unconditioned, it is explained through the two different concepts of nirvana with a remainder of clinging (sopādisesanibbāna) and nirvana without a remainder of clinging (anupādisesanibbāna), with different definitions: the cessation of defilements for the former and the cessation of the aggregates for the latter. The Theravādins need to explain how both nirvana images could be united as one. ${ }^{156}$ This problem had not been solved even at the time of Buddhaghosa.

Apart from the Kathāvatthu, the presentation of doctrines in the form of debates between Buddhist schools is rare in the Theravāda tradition. In the Visuddhimagga, problems concerning nirvana were presented exclusively in the form of debates. The following occurs in the middle of the argument:

[Q.3.] Then is the absence of present [aggregates] as well nibbana? [A.] That is not so. Because their absence is an impossibility, since if they are absent their non-presence follows. [Besides if nibbana were absence of present aggregates too,] that would entail the fault of excluding the arising of the nibbana element with the result of past clinging left (sopādisesanibbānadhātu), at the path moment, which has present aggregates as its support. [Q.4.] Then will there be no fault if it is non presence of defilements [that is nibbana]? [A.] That is not so. Because it would then follow that the noble path was meaningless. For if it were so, then, since defilements [can be] nonexistent also before the moment of the noble path, it follows that the noble path would be meaningless. ${ }^{157}$ 
If nirvana is the absence of the present, past and future aggregates as in 5 the case of nirvana after death, nirvana with a remainder of clinging (saupādisesanibbāna) is not possible since it has present aggregates as its support; whereas if nirvana is the absence of defilements as in the case of nirvana at enlightenment, not only is the noble path futile but also it excludes nirvana without a remainder of clinging (anupädisesanibbāna). The Therāvadins' answer seems to be that nirvana exists separately ( pätiyekka) from both cessations.

In the Sammohavinodanī, the commentary on the Vibhanga, the Therāvadin argument was presented in the form of debates between the Therāvadin and a disputant (vitandavādin) who insists that nirvana is mere destruction (khayamatta). ${ }^{158}$ The argument for the latter was presented in the following way:

But a disputant (vitandavadin) has said: 'There isn't anything existing separately called nibbāna. Nibbāna is just the cessation of the defilements.' And when he is asked to quote a sutta, he quotes the Jambukhādaka-sutta: 'It is said, o friend Sāriputta, nibbāna, nibbāna. Then what is indeed, o friend, nibbāna? The cessation of passion, the cessation of hatred, and the cessation of delusion, $O$ friend, that is indeed called nibbāna', and says 'Through this sutta it should be understood that there isn't anything existing separately called nibbāna. Nibbāna is just the cessation of the defilements. ${ }^{159}$

The Theravādins' answer to this disputant (vitandavādin) is that nirvana is defined as the cessation of passion, the cessation of hatred and the cessation in the Vibhanga ${ }^{160}$ not because it is mere destruction but because 'passion etc. cease on coming to this (tam ägamma) [nibbāna] ${ }^{161}$

Later in the text, the disputant (vitandavädin) came back to this point and said: 'You say "on coming to, on coming to". From where have you got this "on coming to"?' The passage given by the Theravādin is 'thus ignorance and craving, on coming to this, are destroyed in this, are abolished in this, nor do they do anything anywhere'. ${ }^{162}$ A key phrase, 'on coming to this' (tam ägamma), was also applied in the Visuddhimagga: 'because craving fades away and ceases on coming to that, it is therefore called "fading away" and "cessation". 163

However, neither a sutta corresponding to this passage nor the phrase 'on coming to this' (tam ägamma) can be found within the Theravādins' four nikayas ${ }^{164}$ Where could this answer of the Sammohavinodani originate from? In my opinion, it could have originated from the literal meaning of attham paleti seen in the above mentioned Parrayyana stanza. ${ }^{165}$ The use of the locative case in this quoted sutta seems to suggest that it could have been influenced by the Sarvāstivāda-Vaibhāșika's use of the locative case ${ }^{166}$ in explaining the 
existence of nirvana: 'because it does not appear in that, it [nirvana] is nonappearance'. ${ }^{167}$

As explained earlier, ${ }^{168}$ attham paleti in the Pārāyana stanza is synonymous with attham gacchati or atthangama. Although these words usually refer to 'annihilation, disappearance' as opposed to samudaya and synonymous with cessation (nirodha), they can also refer to the setting of the sun in the sense that it goes to asta, the Sanskrit equivalent of the Pali attha, meaning 'home, the western mountain behind which the sun is supposed to set'.

If this literal interpretation of these words is applied to the Pärayana stanza, it could further mean that the Tathāgata after death does not go to nothing but goes to somewhere, like home or the western mountain, as a kind of resting place. Although it is impossible to explain grammatically how the phrase tam ägamma derived from attham paleti or attham gacchati, its literal meaning fits perfectly with the Theravādins' later position on nirvana: it is the cessation consisting in non-arising and exists separately ( pattiyekka) from the mere destruction of passion, hatred and delusion.

In other words, the underlying idea behind the phrase 'on coming to this' (tam ăgamma) in the Sammohavinodani could have been inspired by the literal meaning of attham paleti, which was applied to nirvana without a remainder of clinging (anupādisesanibbāna) in the Pārāyaṇa stanza. 


\section{5 \\ NIRVANA IN NORTHERN BUDDHIST SCHOOLS}

In the previous chapter, we saw that the nirvana concept found in the later Theravāda exegeses was of cessation consisting in non-arising and of existing separately (pātiyekka) from the mere destruction of passion, hatred and delusion. Apart from numbers, their concept seems to come close to that of the Sarvāstivādins that had been established from their unique position: insisting on the existence of all dharmas in the three time periods while accepting the momentariness of conditioned dharmas. ${ }^{1}$ As seen briefly in Chapter 3, under 'The Chinese abhidharma works', their equivalent of nirvana was called extinction through knowledge (pratisamkhyānirodha), which was a single perpetual separation of an impure dharma from a series of aggregates through the antidote, 'acquisition of disjunction' (visamyogaprāpti).

This positive interpretation of nirvana could not satisfy the Sautrāntikas because nirvana for them was not a real existent but a mere designation

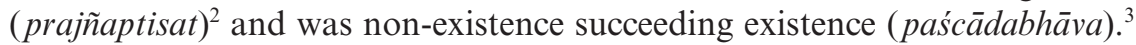
Because the Sautrāntikas were critics of the Sarvāstivādins, how to interpret nirvana became a subject of a debate between them. We can see such a debate in the Abhidharmakośabhāsya, ${ }^{4}$ in the Nyāyānusāraśāstra ${ }^{5}$ and even in the Prasannapadā, the commentary on Mülamadhyamakakārik $\bar{a} .{ }^{6}$ The interpretation of Anuruddha's simile mentioned in Chapter 4 seems to be at the centre of the disputes in all three treatises.

In this chapter, I discuss ontological issues of nirvana, especially between the Sarvāstivādins and the Sautrāntikas, by exploring the later development of the two nirvana theory seen in the Mahāvibhāsāśāstra, by checking the Sautrāntika's concept of nirvana that appears in the Abhidharmakośabhāṣya and by dealing with ontological issues surrounding Anuruddha's simile in the above mentioned three treatises.

\section{The development of the two nirvana theory in the Mahāvibhāsāáśātra}

According to the Mahāvibhāșâśāstra, one of the reasons why nirvana with and without a remainder of clinging was explained in the Jũanaprasthāna 
was that there was no complete explanation of the two nirvanas in the early canon (sütras) apart from simply mentioning their names: nirvana with a remainder of clinging (sopadhiśeșanirvānadhātu) and nirvana without a remainder of clinging (nirupadhiśeșanirvānadhātu). The exegesis of the Jñanaprasthāna starts its explanation of the two nirvana theory as follows: ${ }^{7}$

Although the early canon (sütras) says that there are two nirvana elements: nirvana with a remainder of clinging and nirvana without a remainder of clinging, it does not fully explain their meaning. Thus, 'what is nirvana with a remainder of clinging?' and 'what is nirvana without a remainder of clinging?' were fundamental questions for that treatise. ${ }^{8}$ Since they are not clarified [in the early canon], they are explained [in the Jñannaprasthāna].

There are two things we cannot ignore in this explanation. First, this seems to suggest that the above mentioned sütra in the Chinese Ekottara-ägama ${ }^{9}$ explaining the two nirvana theory differently from the Itivuttaka ${ }^{10}$ was neither accepted as an authority nor included within the early canon of the Sarvāstivādins. That is to say, we could say from this passage that that problematic sütra in the Chinese Ekottara-ägama was presumably not part of the Sarvāstivādin sūtra collections, even though the whole collection of their early ăgama has not survived.

Second, despite the detailed explanation of the two nirvanas in the Itivuttaka, that clarification was not accepted as authoritative by the Sarvāstivādins. As seen in Chapter $3{ }^{11}$ the authenticity of the Pali Khuddakanikaya was not universally accepted among early Indian Buddhists; and the Itivuttaka was translated into Chinese only by Xuan-zang in the late seventh century CE. ${ }^{12}$ The Itivuttaka may have been known to the northern Buddhists not as a sütra but as the chanted verses and the author of the Jñanaprasthāna probably knew this particular chanted verse since there was a strong internal relationship between them. ${ }^{13}$

In fact, the explanation of the two nirvanas in the Jñannaprasthāna does not seem to be linked closely to the dharma theory of the Sarvāstivāda in its fully developed form. For example, it prefers vitality (āyus), which can easily be found in the early canon, to the vital organ (jivitendriya), which is an abhidharmic word, especially for the Sarvāstivādins, one of the fourteen dharmas not associated with the mind (cittaviprayuktasamskāra). Moreover, there was no clear clarification of the relationship between two nirvanas and extinction through knowledge (pratisaṃkhyānirodha), the Sarvāstivāda equivalent of nirvana, in its explanation. Thus, the Mahāvibhāsasaśăstra was interpreting the two nirvana theory in the Jñanaprasthāna in accordance with the fully developed form of their dharma theory. 
What was the Sarvāstivāda-Vaibhāșikas' interpretation for 'with a remainder of clinging' (saupadhiśesa)? While it was vitality $(\bar{a} y u)$ alone in the Jñannaprasthāna ${ }^{14}$ it was both life faculty ${ }^{15}$ (jīvitendriya) and homogeneous character of the group (nikāyasabhāga) ${ }^{16}$ in the Mahāvibhāṣassástra: ${ }^{17}$

When saying vitality, the life faculty (jivitendriya) is meant here. Question: why is homogeneous character of the group (nikāyasabhāga) not mentioned [in the Jñānaprasthāna]? Answer: the author intended to do so and so on. Alternatively, it is not mentioned as that meaning is surely understood from the word with a remainder (sa-śeșa). Alternatively, both the life faculty and homogeneous character of the group are the result of action that projects existence (äkșepakakarman). ${ }^{18}$ As the vital organ is exclusively maturation (vipāka), it ${ }^{19}$ is mentioned alone here [in the Jñannaprasthāna].

One of the obvious steps forward for the Sarvāstivāda abhidharmic systematisation was to interpret vitality $(\bar{a} y u)$ as life faculty (jīvitendriya), since it was defined as 'vitality $(\bar{a} y u)$ of the three spheres of existence' in the Abhidharmakośabhāsya. ${ }^{20}$ This interpretation could not be an isolated phenomenon within the Sarvāstivāda-Vaibhāșikas in Northern India, since life faculty was appeared in the context of the two nirvana theory in the Pali Petakopadesa, which is said to date from around first century CE somewhere in South India. ${ }^{21}$ However, adding homogeneous character of the group (nikāyasabhāga) along with life faculty may have been an isolated phenomenon within the Sarvāstivada-Vaibhāṣika tradition, and this seems to show some characteristics of their abhidharmic systematisation.

Apart from the definition given above, life faculty (jivitendriya) was said, like vitality $(\bar{a} y u)$, to support warmth $(u s m \bar{a})$ and consciousness (vijñāna) according to the Abhidharmakośabhāṣya. ${ }^{22}$ This function seems to have originated directly from the Phenasutta stanza ${ }^{23}$ together with the dialogue between Mahākoțthita and Sāriputta in the Mahāvedallasutta in the Majjhimanikāya ${ }^{24}$ mentioned in Chapter $3 .{ }^{25}$ In this dialogue, vitality was said not only to be interdependent with warmth but also to stabilise the five faculties. This role of supporting the five faculties (indriya) in the early canon seems to influence the later expansion of the life faculty's function in the Mahāvibhāsāsáastra.

Life faculty (jivitindriya) first appeared in the Pali sutta grouped with two controlling faculties of masculinity (purisindriya) and femininity (itthindriya). ${ }^{26}$ These three are included in the well known set of twenty-two controlling faculties in both Northern and Southern Buddhist traditions. ${ }^{27}$ Within early sütras in the Northern tradition, the character and function of life faculty (jivitindriya) is not clearly explained, while its reference to death and the termination of a given life was frequently noticed. ${ }^{28}$ This situation was hardly changed when the life faculty (jivitindriya) was listed and explained as one 
of the twenty-two controlling faculties in the Dharmaskandhapädaśāstra, one of the early abhidharma works of the Sarvāstivādins. ${ }^{29}$ Life faculty (jivitindriya) here was said to work as a faculty that persists, continues, maintains, animates and operates what we called sentient beings. ${ }^{30}$

The attempt to link life faculty (jivitindriya) with vitality $(\bar{a} y u)$ first appeared in the Prakaranapādaśāstra, one of the middle-period abhidharma works of the Sarvāstivādins. ${ }^{31}$ Although the same definition was given in the Abhidharmakośabhāssya, here it was not listed as one of the twenty-two controlling faculties (indriyas) but as one of the fourteen dharmas not associated with the mind (cittaviprayuktasamskāra). ${ }^{32}$

Finally, in the Mahāvibhāșás'âstra this same definition, 'vitality (āyu) of the three spheres of existence', was given to the life faculty listed both as one of the fourteen dharmas not associated with the mind (cittaviprayuktasa$m s k \bar{a} r a)^{33}$ and as one of the twenty-two controlling faculties (indriyas). ${ }^{34}$ That is to say, unifying the life faculty with vitality was completed in the Mahāvibhāsāśăstra, and the character and function of the life faculty thus came from the character and function of vitality $(\bar{a} y u)$.

The Mahāvibhāșáśästra offered two explanations of the character and function of the life faculty (jivitendriya). ${ }^{35}$ While the first was presented as a formal opinion of this treatise, the second appeared as an alternative. In the first case, it was said to have predominating power over our notion of possessing controlling faculties (indriya ${ }^{36}$ and to have predominating power to cause other controlling faculties not to be terminated. Here the function of the life faculty (jivitindriya) was restricted to the other twenty-one controlling faculties and this function seems to have originated from the role of vitality $(\bar{a} y u)$ as support for the five faculties (indriyas) in the above mentioned dialogue between Mahākoțțhita and Sāriputta. ${ }^{37}$

In the second opinion, the life faculty (jivitendriya) was said to have predominating power to form a connection to the homogeneous character

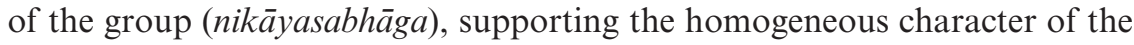
group, protecting and nourishing the homogeneous character of the group and causing the homogeneous character of the group not to be terminated. Here the function of the life faculty was limited to the homogeneous character of the group, which was not part of the twenty-two controlling faculties (indriyas) but part of the fourteen dharmas not associated with the mind (cittaviprayuktasamskāra). In fact, this alternative opinion became a formal explanation of the life faculty (jivitendriya) listed as one of the twenty-two controlling faculties (indriyas) in the Abhidharmakośabhāsya. ${ }^{38}$

This seems to suggest that the role of the life faculty (jivitendriya) was in the process of change in the Mahāvibhāșásiastra, from the earlier explanation oriented to controlling faculties (indriyas) to the later explanation oriented to dharmas not associated with mind (cittaviprayuktasamskāra). According to the second opinion, the life faculty (jivitendriya) without the 
homogeneous character of the group (nikāyasabhāga) would be useless and this could be the reason why the relationship between them was sometimes said to be inseparable. Despite three reasons given above in the text, this shift of the life faculty's role seems to be the real reason behind adding homogeneous character of the group in the interpretation of 'with a remainder of clinging' (saupadhiśeșa) in the Mahàvibhāṣāśástra. That is to say, the inclusion of homogeneous character in the two nirvana theory was mainly responsible for the Sarvāstivādins' abhidharmic systematisation, especially for the shift of the life faculty's function along with their doctrinal development of the fourteen dharmas not associated with the mind (cittaviprayuktasamskāra).

How did this change affect the Sarvāstivāda-Vaibhāṣikas' interpretation of 'with a remainder of clinging' (saupadhiśeșa)? It seems to let them to interpret clinging (upadhi) differently from the conventional meaning of the word. In the Mahāvibhāṣāśästra, clinging (upadhi) is glossed as follows: ${ }^{39}$

When saying 'as there still is a remainder of clinging', clinging is of two kinds: clinging as defilement (kleśopadhi) and clinging as birth body (janmakāyopadhi). An arahant no longer has the first, the clinging as defilement, but he still has the second, the clinging as birth body. Alternatively, clinging is of two kinds: defiled (klișta) clinging and undefiled clinging. An arahant no longer has the first; while he still has the second. ${ }^{40}$

Here the word clinging refers to two different things: defilement and birth body (janmakāya). In 'Etymology of upādi' in Chapter 2, I focused on the double aspect of the word upādi: subjective and objective. In the subjective sense, it denotes defilements in general as the main cause of continuous rebirth and is used in the context of the four noble persons; in the objective sense, it means the 'fuel' of a fire underlining 'the five aggregates' in a metaphorical structure and is used in the context of nirvana. At this late stage, when the Mahāvibhāṣassáastra was composed, its objective meaning seems to have been long forgotten. This seems to have caused one serious problem to later masters of the abhidharma.

Two nirvanas, nirvana with a remainder of clinging (sopadhiśeșanirvān$a d h \bar{a} t u$ ) and nirvana without a remainder of clinging (nirupadhiśeșanirvān$a d h \bar{a} t u$ ), could not be differentiated simply by the existence of defilement, the subjective aspect of the word clinging (upadhi), since both nirvanas no longer had any defilement left. Although what clinging (upadhi) refers to is supposed to make a difference, 'defilement', the widely circulated meaning of the word upadhi at that time, could not differentiate between the two nirvanas. In the first opinion, the difference between the two was made not by the existence of 'defilement' but by the existence of 'birth body' (janmakäya). In 
my opinion, this new exegesis only became possible through the inclusion of 'homogeneous character of the group' in the content of 'with a remainder of clinging' (saupadhiśeșa).

In the early abhidharma works of the Sarvāstivādins, the function of homogeneous character of the group was linked exclusively to the rebirth process and was described as a dharma that determines the specific rebirth state of sentient beings. ${ }^{41}$ Although homogeneous character (sabhägatā) was described later in the second chapter of the Abhidharmakośabhāsya as an abstract principle of universality or homogeneity by which entities are recognized as members of the same category or class, ${ }^{42}$ its original usage was retained in the fourth chapter of the Abhidharmakośabhāsya in the discussion of whether one action (karma) projects one birth or many births. The formal answer for the Sarvāstivādins was 'one [action] projects one birth' (ekam janmākșipatyekam) and 'birth' here was glossed as the homogeneous character of the group (nikāyasabhāga). ${ }^{43}$

We can trace this back to the lengthy discussion in the Mahāvibhāṣāśästra of whether an action (karma) of a moment projects one or many homogeneous characters of the group. ${ }^{44}$ The Sarvāstivāda-Vaibhāșika answer was that 'an action (karma) of a moment projects only one homogeneous character of the group'. If an action can project many homogeneous characters of the group, one should admit that the same action (karma) could result in both birth as a human being and birth in hell and the same maturation (vipāka) could lead to both birth as a human being and birth in hell. ${ }^{45}$ If many actions can together project one homogeneous character of the group, the projection of existence would take place in parts, since some actions lead to birth in hell while some actions lead to birth as a human being. ${ }^{46}$

We can see the same position taken in the third option for the inclusion of homogeneous character of the group in the context of 'with a remainder of clinging': 'both the life faculty and the homogeneous character of the group are the result of an action that projects existence (ākssepakakarman) $)^{9}{ }^{47}$ This identification of birth (janman) with homogeneous character of the group (nikāyasabhāga) could allow the Sarvāstivāda-Vaibhāṣikas to distinguish nirvana with a remainder of clinging (sopadhiśsșanirvānadhātu) from nirvana without a remainder of clinging (nirupadhiśeșanirvānadhātu) by the word 'birth body' (janmakāya).

In 'The Sarvāstivāda interpretation in the Jñānaprasthāna' in Chapter 3, I showed that the Jñannaprasthanna explanation of the two nirvanas could be half way between the old clarification by the existence of the five faculties (pañcindriyāni) in the Itivuttaka ${ }^{48}$ and this new distinction by the existence of vitality $(\bar{a} y u)$ in the later systematisation. Later in the Mahāvibhășáśăstra, the author went a step further to remove all remaining traces of the old Itivuttaka explanation.

The Mahāvibhāsāśăstra presented an anonymous opinion of the two nirvana theory at the end of both exegeses on nirvana with and without 
remainder of clinging. It was based on an unidentified sūtra saying 'As body $(k \bar{a} y a)$, faculty (indriya) and intellect (buddhi) are not yet extinct, it is called nirvana element with a remainder of clinging', ${ }^{49}$ According to the Mahāvibhāṣāsástra, these three were already mentioned in the Jñanaprasthāna with different names: body $(k \bar{a} y a)$ refers to primary elements and secondary matter, faculty (indriya) refers to the five faculties and intellect (buddhi) refers to the mental series. Nirvana with and without a remainder of clinging was thus explained here as follows:

The complete cessation of all fetters (samyojana) is obtained while the series of body, faculty and intellect are not yet extinct. That is why it is called nirvana with a remainder of clinging. ${ }^{50}$

The complete cessation of all fetters (samyojana) is obtained when the series of body, faculty and intellect, or the material body, the mind and mental states, have already become extinct. That is why it is called nirvana element without a remainder of clinging. ${ }^{51}$

In this explanation, what was not extinct was not vitality ( $\bar{a} y u)$, or technically life faculty (jivitendriya) and the homogeneous character of the group (nikāyasabhāga), but the material body, the five faculties and mental series, which together can explain the continuation of the cognitive process. In this respect, this explanation comes close to the old one in the Itivuttaka. ${ }^{52}$ Although the Mahāvibhāṣāsáastra did not mention whose opinion it was, this clarification seems to be very close to the position taken by the Theravādins and, possibly, by their northern equivalent, roughly called the Vibhajyavādins.

The Mahāvibhāssāśāstra criticises this view in an abhidharmic way. It asks, 'Can anyone admit that a saint (arahant) resides neither in nirvana with a remainder of clinging nor in nirvana without a remainder of clinging?' and answers, 'It is impossible by reasoning, yet it is possible from the definitions given here'. ${ }^{53}$ According to this view, it is nirvana with a remainder of clinging when all three things, body $(k \bar{a} y a)$, faculty (indriya) and intellect (buddhi), are present, whereas it is nirvana without a remainder of clinging when one of three things is not present. There could be three possible cases that cannot be determined from this definition of whether a saint is in nirvana with a remainder of clinging or in nirvana without a remainder of clinging:

[1] A saint who is born in the world of formlessness. He does not reside in nirvana with a remainder of clinging, since he cannot have a material body. As his mind is active, he does not reside in nirvana without a remainder of clinging. [2] A saint who is born in the world of form and has entered the absorption of extinction (nirodhasamäpatti). He does not reside in nirvana with a remainder 
of clinging since his mind is not active. As he has a material body, he does not reside in nirvana without a remainder of clinging. [3] A saint who is born in the world of desire but lacks his faculty. He does not reside in nirvana with a remainder of clinging, since he cannot have the five faculties. As he has a material body he does not reside in nirvana without a remainder of clinging. ${ }^{54}$

This kind of definitional conflict frequently occurs in the abhidharma works and it sometimes becomes a kind of driving force for complex doctrinal development. A similar problem occurs when the support for the mental series is discussed. Due to the definition of the world of formlessness (ärüpyadhātu), body (kāya), which was said to be the support of the mental series (cittasamtäna) of living beings in the world of form, cannot exist in the world of formlessness. On this basis, the Sarvāstivādins insisted that the support of living beings in the world of formlessness was life faculty (jīvitendriya), homogeneous character of the group (nikāyasabhāga) and similar kinds of dharmas not associated with the mind (cittaviprayuktasamskära). ${ }^{55}$

We do not know whether the definitional problem was taken seriously by other Buddhist schools or not, yet this seems to be enough for the Sarvāstivāda-Vaibhāșikas to dismiss the old explanation by the five faculties and to give their total support to the new explanation by the existence

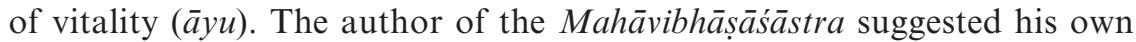
opinion $^{56}$ that whether nirvana was with or without a remainder of clinging was determined solely by the existence of vitality $(\bar{a} y u)$ :

There is an opinion. The text should be written as follows: what is nirvana with a remainder of clinging? The complete cessation of all fetters (samyojana) is obtained (präpta), possessed (pratilabdha), touched (sprșta), and realised (sākșātkrta) by an arahant while his vitality (ayus) alone exists. What is nirvana without a remainder of clinging? An arahant whose vitality has already come to an end destroys all fetters completely. ${ }^{57}$

Although it was not presented as a formal opinion of the SarvāstivādaVaibhāșikas, it seems to be presented as a solution to the above mentioned definitional problem. While there still was some trace of the Itivuttaka clarification left in the Jñanaprasthāna explanation of the two nirvana theory, there was no trace left in this newly proposed solution.

Despite the above modification, this newly proposed opinion continued to apply such terms as 'obtained' ( präpta) and 'possessed' (pratilabdha) only to nirvana with a remainder of clinging (sopadhiśeșanirvānadhätu), as in the case of the Jñanaprasthāna. The question arose why these terms were not applied to nirvana without a remainder of clinging (nirupadhiśeșanirvānadhātu). The following two answers were given in the Mahāvibhāsāaśästra: 
'obtained and so on' is used with reference to present acquisition ( $p r a \bar{p} p t i)$. It is not used when present acquisition ceases. Alternatively, 'obtained and so on' is conventionally designated (prajñapti) in respect of a person (pudgala). There is no person but dharma in itself (dharmata $)$ in [nirvana without a remainder of clinging], so it is not mentioned here. ${ }^{58}$

Whereas the first answer tells us why these terms were applied to the nirvana with a remainder of clinging (sopadhiśeșanirvānadhātu), the second answer shows how the Sarvāstivāda-Vaibhāṣikas understand the ontological state of nirvana without a remainder of clinging (nirupadhiśeșanirvānadhātu).

In 'Upädisesa within the context of nirvana' in Chapter 2, I showed that the significance of no-self (anätman) in terms of the cognitive theory could be that there is no need for a self ( $\bar{a}$ tman) behind the five aggregates to explain our cognitive process. This did not mean that all early Buddhists had the radical theory presented in the simile of a cart in the Milindapañha against the Upanișadic notion of self (ätman). ${ }^{59}$ What Indian Buddhist schools said was that self (ätman), or person (pudgala), exists not as an entity (dravya) but simply as a designation (prajñapti) ${ }^{60}$ What was designated was, especially for the Sarvāstivāda-Vaibhāșikas, the series of aggregates (skandhasamitāna).

As seen in 'The Chinese abhidharma works' in Chapter 2, nirvana for them was extinction through knowledge (pratisamkhyänirodha), which was further defined as disjunction (visamyoga). Nirvana with a remainder of clinging (sopadhiśeșanirvānadhātu) could be achieved by a person (pudgala), technically the series of aggregates (skandhasamtanna), who has terminated all connections with defilements and as a consequence has henceforward been protected from them through antidotes, the acquisition of disjunction (visamyogaprāpti) against all defilements existing in the three time periods.

According to the Mahāvibhāsasaśăstra, disjunction can be attained by an ordinary person (prthagjana), śaikșa or aśaikșa, yet nirvana with a remainder of clinging or nirvana without a remainder of clinging can be attained only by an aśaiksa ${ }^{61}$ Through terminating junctions with impure dharmas and attaining the acquisition of disjunction, a person can advance from laity to śaikșa and to aśaikșa. Thus, disjunction can only be nirvana with a remainder of clinging at the moment when the last defilement left is terminated, whereas disjunction can only be nirvana without a remainder of clinging at the moment when the last defilement left is terminated and at the same time his vitality ( $\bar{y} y u s)$, or technically life faculty (jīvitendriya) and homogenous character of the group (nikāyasabhāga), is destroyed.

As pointed out in the first answer, ${ }^{62}$ nirvana with a remainder of clinging (sopadhiśeșanirvānadhātu) can be the present acquisition (prāpti) of disjunction against the very last defilement left that was archived by a living saint (arahant), or the series of aggregates, and in this respect we can say 'the complete cessation of all fetters (samyojana) is obtained (prāpta), possessed 
(pratilabdha), touched (sprșta) and realised (sākșätkrta) by a saint'. Since there is no person (pudgala) in the final nirvana, these terms cannot be applied to nirvana without a remainder of clinging (nirupadhiśsșanirvānadhātu).

What could be the possible picture of the state of nirvana without a remainder of clinging? From the above expression, 'there is no person but dharmas in themselves (dharmatā) ${ }^{,},{ }^{63}$ we can assume that it was the disintegration of the series of aggregates (skandhasamtäna) owing to there being no more driving force, such as defilement, left to continue the series. That is to say, the series of aggregates that is conventionally designated as a person (pudgala) has been disintegrated, yet all dharmas that constitute that series of aggregates continue to exist because they are real existents in the three time periods.

Thus, if the Sarvāstivāda-Vaibhāșikas were asked what happens to the Tathägata after death, one of the unanswered questions, their technical answer could be that 'The Tathägata was only a designation for the series of aggregates in which all junctions with defilements have been terminated and thus acquisitions of disjunction with all defilements have been attained. When the life faculty and homogenous character of the group have been destroyed this series of aggregates finally disintegrates and only dharmas in themselves remain.' This last point, the existence of dharmas, was the Sautrāntika's main target when arguing against the ontological position of the Sarvāstivāda-Vaibhāṣikas.

\section{The Sautrāntika's criticism of ontological issues around nirvana}

Before going into the ontological issues around nirvana, we need to look at who the Sautrāntikas were and how they dealt with the two nirvana theory. An interesting comment on the chronology of the Sautrāntikas was given by Kui-ji (窺基), a principal disciple of a famous Chinese translator Xuanzang, in his Cheng-you-shi-lun Shu-ji (成唯識論述記), the Chinese commentary on the Vijñäptimātrasiddhiśästra ${ }^{64}$ According to him, the origin of the Sautrāntikas goes back to Kumāralāta, an influential Buddhist master based in the north Indian city of Takșaśila around a hundred years after the death of the Buddha. Though he was one of the five Sauryodayikas, a name given to them because their emerging influence among Buddhists at that time was compared to the rising sun, he and his followers were called the Dārsțāntikas mainly because of his book, the Drștāntamālāśästra, and his tendency to explain Buddhist doctrines with similes. The name Sautrāntika only arose after the death of Śrīata, the second Sautrāntika master, believed to have lived four hundred years after the death of the Buddha and to have written the Sautrāntikavibhāsā.

The plausibility of this late seventh-century comment by Kui-ji (窺基) has been strongly contested and a study by Kato suggests that the date of Kumāralāta cannot go back to a hundred years after the death of the Buddha, 
but must postdate the composition of the Mahāvibhāsāsáastra, and that Kumāralāta was probably the teacher both of Harivarman and of Śrīlāta, who was the direct teacher of Vasubandhu.$^{65}$ Kato has also contested the chronological view based on the above comment that the earlier term Dārștāntika was replaced by the term Sautrāntika in the later period. He suggests that the name Sautrāntikas had a positive connotation and was used by the group itself to refer to its own views, whereas Dārșțāntikas has a negative connotation and was used by opponents, such as the SarvāstivādaVaibhāṣikas. ${ }^{66}$

Whether this group was called the Dārștāntikas or the Sautrāntikas, we still do not know it was established as an independent sect with its own vinaya. As pointed out by Cox, it emerged just prior to the composition of the Mahāvibhāșáśästra not as a distinct ordination lineage or sect, but as a dogmatically defined group or school that objected to the Sarvāstivāda doctrinal interpretation. ${ }^{67}$

\section{The Sauträntikas and the two nirvana theory}

Although the Sautrāntikas may have produced their own exegetical treatises, such as the Sautrāntikavibhāṣa , none of them has survived in a complete form. From the citations attributed to Sthavira, possibly Śrīlāta, in Sanghabhadra's $N y \bar{a} y \bar{a} n u s \bar{a} r a$, we assume that they may have systematically composed exegetical treatises to the abhidharma texts and treatises of the Sarvāstivāda-Vaibhāșikas. ${ }^{68}$ None the less, what we see from the Abhidharmakośabhāssya is that they were vicious critics of the SarvāstivādaVaibhāșikas, especially of their dharma theory.

In his work, Vasubandhu was largely following the SarvāstivādaVaibhāșika system, while making critical comments on points that he, or the Sautrāntikas, did not agree with. Since there is no complete explanation of the two nirvana theory in the Abhidharmakośabhassya, we can assume that he was roughly following the explanation of the Sarvāstivāda-Vaibhāṣikas seen in the Jñannaprasthāna ${ }^{69}$ and the Mahāvibhāsas̄sástra. ${ }^{70}$ However, there is a substantial difference from the detailed analysis of the characteristics of dharmas involved in the two nirvana theory.

The interpretation of 'with a remainder of clinging' (saupadhiśeșa) has been the heart of understanding the two nirvana theory. For the SarvāstivādaVaibhāșikas, it was, as seen before, ${ }^{71}$ both life faculty (jīvitendriya) and homogeneous character of the group (nikāyasabhäga), according to the Mahāvibhāsāśáastra. As far as the Sautrāntikas were concerned, this interpretation could not be accepted, since both dharmas belonged to the fourteen dharmas not associated with the mind (cittaviprayuktasamskāra), which they did not accept as real existents.

Although Vasubandhu denied that both dharmas were real existents, the way in which he rejected them was different. While the first, life faculty, he 
regarded as a name (prajñapti) given to something else, the second, homogeneous character (sabhāgatā), he considered to be non-existent.

Although the homogeneous character of the group (nikāyasabhāga) was virtually the same as homogenous character (sabhägat $\bar{a}$ ) according to the Abhidharmakośabhāssya ${ }^{72}$ the homogeneous character (sabhāgatā) described in the text was different from what we have seen in the Mahāvibhāșassástra with the name of homogeneous character of the group (nikäyasabhäga). In the Abhidharmakośabhāsya it was understood not as a dharma operating exclusively in the rebirth process to determine the specific rebirth state of sentient beings ${ }^{73}$ but as an abstract principle of universality through which entities are recognized as members of the same category or class. ${ }^{74}$

In this respect, it was more like the generality (sämānya) or particular generality (sāmānyaviśeșa) of the Vaiśeșikas. This was pointed out by Vasubandhu in one of the five arguments against the existence of homogeneous character in the Abhidharmakośabhạsya. ${ }^{75}$ Among the five, ${ }^{76}$ the second argument seems to be a classic example to show how the Sautrāntikas refute the existence of this dharma. It reads as follows: 'Neither can ordinary people (loka) see homogenous character, since it is without form (rüpa), and is not distinguished through knowledge ( $\operatorname{prajn} \bar{a}) .{ }^{977}$

Despite the name Sautrāntika, which gives the impression that their argument depends largely on textual testimony (sütra), they were also keen on using two other criteria used by traditional Indian scholars: direct perception (pratyakșa) and inference (anumāna). ${ }^{78}$ Although seeing (paśyati) alone was mentioned, seeing here was used to stand for perception in general. As pointed out by Jayatilleke, ${ }^{79}$ seeing has been used predominantly over other forms of perception since the Upanisad, and this can be justified simply by the fact that the largest number of our perceptions are visual perceptions. Thus, the word for visual perception is extended to denote perception in general.

Although the word knowledge ( $\operatorname{raj} \tilde{n} \bar{a}$ ) was used in the second negation, it represented, as glossed by Yaśomitra, the second criterion, inference (anumāna). In fact, both words, pratyakșa and anumāna, are mentioned in the interpretation of this argument in his Sphutārthā Abhidharmakośavyākhyā, the commentary on the Abhidharmakośabhāsya ${ }^{80}$ Thus, homogeneous character (sabhāgatā $)$ was, as in the case of asamskrta ${ }^{81}$ and pudgala, ${ }^{82}$ neither recognized through direct perception (pratyakșa), like form (rüpa), nor inferred through inference (anumāna), like the faculty of sight.

Where does this abstract principle come from? The answer given from Vasubandhu was that it was simply non-difference of birth, or category (jätyabheda). ${ }^{83}$ The logic behind this answer was that homogeneous character (sabhāgatā) is not a separate existent but just the absence of difference, and the lack of something cannot be a real existent. Vasubandhu used similar logic to define the truth as 'lack of contradiction' (aviparita), in order to interpret the third noble truth as non-existence. ${ }^{84}$ 
Since homogeneous character was regarded as non-existent, the Sautrāntika interpretation of 'with a remainder of clinging' (saupadhiseșa) depends solely on how they saw life faculty (jivitendriya). Although it too was not regarded as a real existent, like homogeneous character (sabhägatā), it was treated slightly differently in the Abhidharmakośabhāsya. It said, 'We do not say it does not exist at all, yet say it is not a real existent' ${ }^{85}$ This means that it is not a real existent (dravya) but a name (prajñapti) given to a certain phenomenon.

Vasubandhu's answer for that was as follows: 'momentum (âvedha) at the time of placing homogeneous character of the group (nikāyasabhäga) through an [previous] action in the three worlds ${ }^{86}$

Homogeneous character of the group (nikāyasabhāga) mentioned here seems to retain its old usage, functioning exclusively in the rebirth process mentioned above, ${ }^{87}$ and is somehow different from the abstract principle that has just been rejected. It is the direct result of an action that projects new existence (äkșepakakarman), ${ }^{88}$ and is glossed in the Sphuțārthā Abhidharmakośavyākhyā as 'it is samskārā of that kind that have the aggregates, such as material form, as their intrinsic nature' ${ }^{89}$

What is said in this passage is that life faculty is not a real existent but a name given to a certain power of the series of aggregates (skandhasamtāna) initiated directly by an action that projects new existence (ākșepakakarman) at the moment of conception. We can compare the position of the Sarvāstivāda-Vaibhāșikas and of the Sautrāntikas through the simile of shooting an arrow seen in the Abhidharmakośabhạsya. ${ }^{90}$

The former, the Sarvāstivāda-Vaibhāṣikas, believed that the destiny of an arrow and the time it will take to reach its destination can be determined by a certain sort of quality (guna), or possibly samskāra, that arises separately in the arrow through the impetus and the direction of the arrow at the moment of the shooting. As a consequence, the destiny and the duration of a sentient being, or technically a series of aggregates, are determined by separate dharmas, i.e. life faculty (jivitendriya) and homogenous character of the group (nikāyasabhāga), which arise from an action that projects new existence.

By contrast, the latter, the Sautrāntikas, believed that the destiny of an arrow and the time it will take to reach its destination are initiated directly by the impetus and the direction of the arrow at the moment of the shooting. Thus, the destiny and the duration of a sentient being, or technically of a series of aggregates (skandhasamtanna), are initiated directly by the action that projects new existence (a kssepakakarman) at the moment of conception. ${ }^{91}$

This seems to explain why the Sautrāntikas were also known as the Sañkrāntivādins, those who maintain the transference of the aggregates (skandhas) seen in the Chinese translation of the Vasumitra's Samayabhedoparacanacakra. ${ }^{92}$ Within the Sautrāntika system, the transmigration from one world to the other can be explained exclusively by the series of aggregates. 
Table 5.1 Rebirth process between the Sarvāstivāda-Vaibhāṣikas and the Sautrāntikas

\begin{tabular}{|c|c|c|c|}
\hline \multicolumn{4}{|c|}{ rebirth process } \\
\hline $\begin{array}{c}\text { Sarvāstivāda- } \\
\text { Vaibhāṣikas }\end{array}$ & $\bar{a}$ assepakakarman & $\begin{array}{c}\text { jīvitendriya } \\
\text { nikāyasabhāga }\end{array}$ & skandhasaṃtāna \\
\hline Sautrāntikas & $\bar{a} k s$ epakakarman & the momentum (āvedha) of skandhasaṃtāna \\
\hline
\end{tabular}

Table 5.1 summarises the difference between the Sarvāstivāda-Vaibhāșika and the Sautrāntika. For the Sautrāntikas, there is no need to assume the existence of both dharmas not associated with the mind (cittaviprayuktasamskära) to explain the process of conception, especially from the previous action to the present psychophysical series of aggregates (skandhasamtāna).

The outcome of this Sautrāntika criticism could not be ignored, since it could change the whole interpretation of the two nirvana theory that had been carefully established by the Sarvāstivāda-Vaibhāșikas in the Jñanaprasthāna and the Mahāvibhāsāśs̄stra. The core of their interpretation of the two nirvana theory concerns what clinging (upadhi) in 'with a remainder of clinging' (saupadhiśeșa) refers to. The answer given by the Sarvāstivāda-Vaibhāṣikas

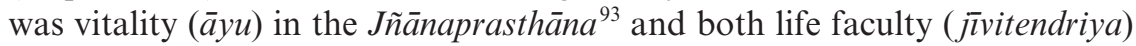
and homogeneous character of the group (nikāyasabhāga) in the Mahāvibhāṣāśāstra. ${ }^{94}$

Their answers did not represent either of the two aspects of the word clinging (upadhilupādi): in the subjective sense it denotes defilements in general; in the objective sense it denotes the 'fuel' of a fire underlining 'the five aggregates' in a metaphorical structure. ${ }^{95}$ That is to say, the SarvāstivādaVaibhāșika's interpretation of the two nirvana theory was established under the heavy influence of their abhidharmic systematisation.

Although their possible reference for 'with a remainder of clinging' (saupadhiśeșa) is 'the momentum (āvedha) of the series of aggregates (skandhasamtāna)', this is not a separate existent, like life faculty and homogeneous character in the Sarvāstivāda-Vaibhāṣika, but a name given to a certain power that belongs to the series of aggregates. Whether so intended or not, the Sautrāntika criticism of both dharmas not associated with the mind (cittaviprayuktasamskāra) seems to turn this tide and let the interpretation of the two nirvana theory return to the metaphorical structure of nirvana in the early canon.

\section{Nirvana from the Sauträntika ontological perspective}

In 'The Chinese abhidharma works' in Chapter 3, we saw that the Sarvāstivāda-Vaibhāșika understanding of nirvana was closely related to 
their dharma theory, the existence of all dharmas in the three time periods and their acceptance of the momentariness of conditioned dharmas. Their equivalent of nirvana in this tradition was called extinction through knowledge (pratisamkhyānirodha) and was explained as the perpetual separation of an impure (sāsrava) dharma from a series of aggregates (skandhasamtāna) through the antidote called 'acquisition of disjunction' (visamyogapräpti) ${ }^{96}$

By contrast, the Sautrāntika understanding of nirvana was closely related to their ontological position. For them, nirvana is not a real existent (dravyasat) but a mere designation (prajñaptisat), something spoken of conventionally, and is 'non-existence succeeding existence ( $p a$ s'cādabhāva)', like a sound that is non-existent before and will be non-existent after its occurrence. ${ }^{97}$ 'Neither an intrinsic nature (svabhāva) is perceived, like the form (rūpa), feeling and the like, nor is an activity perceived, like that of the eye and the like. ${ }^{98}$

Their definition of extinction through knowledge (pratisamkhyānirodha), or nirvana, occurs in the second chapter of the Abhidharmakośabhāsya, as follows: 'The extinction through knowledge is, when latent defilements (anuśaya) and life (janman) that have already been produced are extinguished, non-arising of further such by the power of knowledge (pratisamkhyāa). ${ }^{99}$ Later, in Yaśomitra's Sphuțārthā Abhidharmakośavyākhyā, the cessation of latent defilements (anuśayanirodha) was glossed as nirvana with a remainder of clinging (sopadhiśeșanirvānadhātu), while the cessation of life (janmanirodha) was explained as nirvana without a remainder of clinging (nirupadhiśeșanirvānadhātu). ${ }^{100}$

If we apply this explanation of Yaśomitra back to Vasubandhu's definition, nirvana with a remainder of clinging for the Sautrāntikas could be, when latent defilements (anuśaya) that have already been produced are extinguished, the non-arising of further such by the power of knowledge; whereas nirvana without a remainder of clinging could be, when life (janman) that has already been produced is extinguished, the non-arising of further such by the power of knowledge. Two things in this analysis cannot be ignored.

First, the Sautrāntika's use of the word nirvana seems to be quite different from that of the Sarvāstivāda-Vaibhāșikas. As we saw above, nirvana for the Sarvāstivāda-Vaibhāșikas was a single perpetual separation of an impure (sāsrava) dharma from a series of aggregates through the antidote called 'acquisition of disjunction' (visamyogapräpti) and, as a consequence, it could be used for every single perpetual separation. ${ }^{101}$ By contrast, nirvana for the Sautrāntikas could be used only for the traditional two cases: nirvana with a remainder of clinging (sopadhiśeșanirvānadhātu) and nirvana without a remainder of clinging (nirupadhiśeșanirvānadhātu).

As seen in the definition above, nirvana was not described as a single extinction of a latent defilement (anuśaya) but as non-arising of further latent defilement when all latent defilements that have been produced have already been extinguished. In this respect, the Sautrāntikas seem to keep, like the 
Theravāda exegetical tradition, ${ }^{102}$ the old usage of the word nirvana, which was applied to the two most important events in the Buddha's life: enlightenment and final liberation at death. ${ }^{103}$

Second, the word anuśaya (latent defilement) was used in the case of nirvana with a remainder of clinging, in contrast to the usual word 'defilement' (kleśalkilesa) $)^{104}$ or 'impurity' (äsrava $)^{105}$ preferred by the Theravādins and the Sarvāstivāda-Vaibhāșikas. In fact, this small terminological shift seems to be the key to understanding how nirvana was explained in the Sautrāntika system.

In general, latent defilement was, according to Jaini, ${ }^{106}$ 'always used in the sense of a bias, a proclivity, a persistence of a dormant or latent disposition of mind leading to all kinds of evil volitions'. While the terms kleśa and āsrava tend to designate defilements in general, anuśaya refers only to defilements in their latent state. In the Abhidharmakośabhāsya, this lantent defilement was explained as sleeping ( prasupta) defilement, in contrast to paryavasthāna, which was explained as awakened (prabuddha) defilement. The former was further commented on this: 'in the non-manifested state, it persists in the state of being seed (bijabhāva)', whereas the latter was commented on as 'manifested state' (sammukhībhāva). ${ }^{107}$ The relationship between these terms is summarised in Table 5.2.

What could be the reason why the Sautrāntikas, the followers of the sūtras, had to explain nirvana with a term, anuśaya, that was not at all common in the early canon? The answer seems to be closely related to one of the ontological problems they had to face, especially against the SarvāstivādaVaibhạșikas, who insisted on the existence of all dharmas in the three time periods while accepting the momentariness of conditioned dharmas.

Within the Sarvāstivāda-Vaibhāșika system, these two apparently opposing views were skilfully reconciled by saying that what changes each moment is not the intrinsic nature (svabhāva) of a dharma but its activities - arising, duration, decay and ceasing - through its inherent characteristic (svalakșana) of impermanence. ${ }^{108}$ By contrast, the Sautrāntikas did not accept the idea that all dharmas exist in the three time periods and maintained that there is no difference between the intrinsic nature of a dharma and its activities. What changes momentarily is thus dharmas themselves: their existence is constituted by their activities. ${ }^{109}$

The outcome of this Sautrāntika ontological perspective was that a causal relationship could be established only between a moment and the immediately preceding moment. In other words, causal efficacy from the more

Table 5.2 Kleśa and anuśaya from the Sautrāntika viewpoint

\begin{tabular}{|c|c|c|}
\hline \multirow{2}{*}{$k$ kleśa } & paryavasthāna & manifested state (saṃmukhībhāva) \\
\cline { 2 - 3 } & anuśaya & state of being seed (bījabhāva) \\
\hline
\end{tabular}


distant past could no longer be sustained, since no dharma can remain for more than a moment. ${ }^{110}$ This extreme ontological position of the Sautrāntikas seems to cause problems, especially in explaining the karmic process, from defilement to action and to its result. They have to explain how defilement can be sustained within and be abandoned from a series of aggregates, since it automatically ceases after coming into existence.

Within the Sarvāstivāda-Vaibhāṣika system, this karmic process can largely be explained through a dharma called acquisition (prapti), which is one of the fourteen dharmas not associated with mind (cittaviprayuktasamskāra). ${ }^{111}$ When there is an arising of the acquisition of the defilement, the acquisition ( prāpti) makes the defilement renew its existence and continue its activity arising, duration, decay and ceasing - until this acquisition is eliminated from the series. ${ }^{112}$

The explanatory model applied by the Sautrāntikas was called the theory of seed (bijja). In the fifth chapter of the Abhidharmakośabhassya, the above mentioned 'state of being seed' (bījabhāva), or latent defilement (anuśaya), was defined by Vasubandhu as follows:

What is here called the state of being seed? It is the power (śakti) of a body (ätmabhāva) to produce defilement which is born of [previous] defilement, just like the power to produce memory which is born of [previous] perception or knowledge and just like the power of a sprout and so on to yield rice which is born of [previous] rice. ${ }^{113}$

Although this name and form (nämarūpa), which is the support (äsraya) ${ }^{114}$ of that power, is momentary, they continue (samtati) by means of a causal relationship between a moment and the immediately preceding moment, and the current of these successive moments of name and form constitutes what we called the series of aggregates (skandhasamtāna). This power of the series of aggregates is conventionally called 'latent defilements' and in the Sautrāntika system is technically called 'the state of being seed'.

As an answer to the first question raised above, how defilement can be sustained within a series of aggregates, the Sautrāntikas might well say that what has been sustained within a series of aggregates is not a separate dharma, or a certain defilement, which will cease immediately after existence, but the power of the series of aggregates to produce the defilement, which can continue as long as the series continues uninterrupted until it is manifested (paryavasthāna) when the right conditions are given.

As an answer to the second question, how defilement can be abandoned from a series of aggregates, the Sautrāntikas might well say that what has been abandoned is not a separate dharma, or a certain defilement, but the power of the series of aggregates that can produce the defilement. This process of abandoning defilements was described by Vasubandhu in the Abhidharmakośabhāṣya as follows: 
And by the two kinds [past and present] of defilements, the state of being seed (bijjabhāva) is implanted in this series to arise in future. Through the abandonment of that [seed], that [defilement] too is abandoned. In the same way as through exhausting maturation (vipāka), action (karma) is exhausted. ${ }^{115}$

Within the theory of seed, the mechanism of producing its result was explained by the special transformation of a series (samtānaparināmaviśeșa). ${ }^{116}$ It is applied within the Abhidharmakośabhāsya to explain various phenomena that could be awkward to explain from the Sautrāntika's extreme ontological position: for instance, the continuation of defilements in the form of anuśaya seen above, the continuation of our memory ${ }^{117}$ and the continuation of the efficacy of past action (karma) through its maturation (vipāka). ${ }^{118}$

Vasubandhu seems to use it as a hidden weapon to defend the Sautrāntika's position when asked how a past momentary cause can produce a present momentary result. In this respect, it mainly replaces the SarvāstivādaVaibhāșika's theory of acquisition (prāpti). ${ }^{119}$ In the second chapter of the Abhidharmakośabhāṣya, these terms were glossed as follows:

What then is called seed (bija)? It is name and form (nāmarūpa) capable of producing a result either immediately or mediately through the special transformation (parināmaviśeșa) of a series (santati). What is here called transformation (parinama)? It is continuing differently [from before]. What then is here called series (santati)? It is samskāra of the three time periods in the state of being cause and result. ${ }^{120}$

When a certain cause was given, the latent capability to produce its result was implanted in ${ }^{121}$ the series of aggregates and passed along through the successive moments of the aggregates that continue the causal relationship between a moment and the immediately preceding moment until it produces its result. In other words, the original cause in the past is not a direct cause of the result because its role is initiating a long sequence of powers to produce its result in the future.

What makes this Buddhist transformation (parinama) different from the Sānkhya concept of transformation is that for the former transformation is a sequence of momentary phenomena arising differently from before, while for the latter transformation is a manifestation of material nature (prakrti) that essentially remains the same.

Although this original cause ceased momentarily in the past, its result will be realised at the last special (viśeșa) moment of the transformation (parinama). ${ }^{122}$ This is explained in the last chapter of the Abhidharmakośabhāṣya as follows: 
What then are 'series', 'transformation' and 'special'? Series is the current of successive moments of mind [initiated by] former action. Transformation (parināma) is arising of that [series] differently [from before]. Further special transformation (parinamaviśeșa) is the capacity of producing a result immediately because of being the distinctive last transformation. ${ }^{123}$

In this transformation the final result was produced from the last moment of the transformation, which has a special and distinctive power to produce its result immediately. The whole process of this special transformation of a series (samtānaparināmaviśesa) was likened to producing a final fruit that is not a direct result of a seed but an indirect result of its long transformation from a seed to a sprout, from a sprout to a flower and finally from a flower to a fruit. ${ }^{124}$

One important question still remains to be answered in this theory: why does the uninterrupted conditioning of successive moments stop at one point and not continue for ever? In other words, why does a new cause that has just been produced by the special transformation not repeat the same transformation again? The answer given by Vasubandhu was a kind of ancient Buddhist equivalent of a modern scientific experiment:

In a way that a red fibre (keśara) appears on the fruit which is born of the special transformation of the series [initiated] by a citron tree's flower coloured with red-dye-liquid, but no other [red fibre] appears again from that [red fruit], in that way there is no other maturation (vipāka) from the maturation which is born of action (karma). ${ }^{125}$

It has been said by some old Chinese and Korean monks that some black peas are produced by planting a pea coloured with Chinese black ink, but planting these black peas will not produce other black peas again. What is being said here is that the efficacy of the original cause lasts once only and does not continue again and again, and this can be applied to such phenomena as the maturation of an action, the latent defilement and memories mentioned before. This seems to make a big difference in the character of nirvana between the Sarvāstivāda-Vaibhāșikas and the Sautrāntikas.

One thing we should remember is that Vasubandhu's theory of seed (bija) and the special transformation of a series (samtānaparināmaviśeșa) seen in the Abhidharmakośabhāșya was still in its provisional form. After explaining them extensively at the end of the Pudgalaviniścaya, the ninth chapter of the Abhidharmakośabhāsya, Vasubandhu simply hid behind the shadow of the Buddha by quoting the following stanza ascribed to Rahula: 'The cause even of a single eye in the feather of peacock cannot be understood in all its 
aspects by non-omniscient ones. For it is knowledge which is the power of the omniscient. ${ }^{126}$ His uncertainty seems to come from the possible interruption of a mental series, especially in nirodhasamāpatti ${ }^{127}$ which will automatically halt the continuum of powers (śakti) conveying future results. This interruption could be the reason why he in the Karmasiddhiprakarana introduced latent consciousness (älayavijñāna) ${ }_{1}^{128}$ which will continue uninterrupted even in nirodhasamäpatti. In that text his uncertainty disappeared when he had explained latent consciousness (älayavijñāna). ${ }^{129}$

As we saw in 'The Chinese abhidharma works' in Chapter 3, nirvana for the Sarvāstivāda-Vaibhāșikas is a real existent (dravya) to protect a series of aggregates perpetually from past, present and future defilements, and is clearly contradicted by the Sautrāntika's definition of nirvana seen above. ${ }^{130}$ In the second chapter of the Abhidharmakośabhāssya, the SarvāstivādaVaibhāsikas made the following objection: ${ }^{131}$

Then if nirvana is only non-arising, how are we to interpret this statement in the sütra: ${ }^{132}$ 'these five faculties if practised, cultivated and developed conduce to the abandonment of past, future and present suffering (duhkha)'? As nirvana [for the Sautrāntikas] is abandonment and is the non-arising only of the future, it cannot be of past and present!

For the Sautrāntikas, there is nothing to be done with past defilements because they cease automatically after awakening (paryavasthāna) and their efficacy cannot last any more. A present defilement cannot last more than a moment. All they need to do is to remove sleeping defilements (anuśaya), in the state of being seed (bijabhāva), which had been planted in a series of aggregates (skandhasamtāna), have been sustained in that series through transformation and will be manifested by the special transformation of the series (samtānaparināmaviśeșa). The answer given by Vasubandhu to the above objection was as follows:

Further, abandonment is the absolute non-arising of future suffering or defilement because of the absence of the state of being seed (bijabhāva). Otherwise what of past and present defilement is there to be abandoned? Indeed there is no profit in making an effort concerning what has already ceased and what is on the point of ceasing. ${ }^{133}$

Once anuśaya, the state of being seed, was destroyed by the power of intuition (darśana) and the noble path (mārga), name and form (nämarūpa), which are the support (áśraya) for the anuśaya, become special (viśeșa); that is to say, move from a normal state of having the power to produce a defilement to a special state of lacking power to produce a defilement. ${ }^{134}$ 
When there is no more anuśaya remaining in a series of aggregates and no more arising by the power of knowledge, it can be called nirvana with a remainder of clinging. Vasubandhu explained the importance of acquiring this special base in the Abhidharmakośabhäsya as follows: 'It is said that nirvana is attained through acquiring the basis (ásraya) which prevents completely the arising of defilement (kleśa) and rebirth (punarbhava), by acquiring an antidote ( pratipakșa). ${ }^{, 135}$

Nirvana without a remainder of clinging for the Sautrāntikas was, as seen above, non-arising of further life (janman) by the power of knowledge when life that has already been produced is extinguished. Life here seems to refer to vitality $(\bar{a} y u)$, which was explained by Vasubandhu as 'momentum (avvedha) at the time of placing homogeneous character of the group (nikāyasabhāga) through an action in the three worlds', ${ }^{136}$ and was glossed in the Sphut $\bar{a} r t h \bar{a}$ Abhidharmakośavyākhyā as 'samnskärā of that kind that have the aggregates, such as form (rüpa), as their intrinsic nature'. ${ }^{137}$

Since this momentum (avedha) was likened later in the text to the power given to the sprout by which the plant develops to maturity, ${ }^{138}$ the continuation of this momentum during life could also be understood by the Sautrāntikas as the state of being seed (bïjabhāva), which when manifested finally at the moment of death will work as dissociated force. That is to say, it will terminate a given life (janman) from the action that projects existence (āksepakakarman) at the moment of conception.

Therefore, the Sautrāntikas' claim that nirvana is non-existence seems to be connected to their own abhidharmic systematisation. As seen here, their understanding of nirvana was closely connected to their theory of karmic mechanism, which was based on the theory of seed (bijjabhāva) and the special transformation of a series (samtānaparināmaviśeșa).

\section{Interpretation of Anuruddha's verse}

In Chapter 4, I briefly mentioned Anuruddha's verse in the context of the Theravāda exegetical tradition. ${ }^{139}$ Although they are not directly involved in a debate on the interpretation of Anuruddha's verse between Northern Buddhist schools, their later exegetical position on nirvana - that it is cessation consisting in non-arising and exists separately (pātiyekka) from the mere destruction of passion, hatred and delusion - seems to support the Sarvāstivāda-Vaibhāșika position. A similar approach to the view that nirvana is mere extinction is found in the Pali Sammohavinodanī of the Theravādins ${ }^{140}$ and in the Nyāyānusāraśāstra of the Sarvāstivāda-Vaibhāșikas. ${ }^{141}$

The interpretation of Anuruddha's verse, believed to have been uttered when the Buddha was finally released at Kuśinagara, ${ }^{142}$ became a kind of battleground between the Sarvāstivāda-Vaibhāṣikas and the Sautrāntika. Vasubandhu used this stanza in a debate on the ontological issue of nirvana against the Sarvāstivāda-Vaibhāșikas in the second chapter of 
the Abhidharmakośabhāsya ${ }^{143}$ and his opinion was later contested by Sanghabhadra in his Nyāyānusāraśāstra from the Sarvāstivāda-Vaibhāșika perspective. ${ }^{144}$ This stanza was later quoted and explained by Candrakīrti in the Prasannapadā, the commentary on Mūlamadhyamakakârikāa. ${ }^{145}$ Vasubandhu quotes this stanza in the Abhidharmakośabhāsya as follows: 'His mind was liberated like the going out of a lamp." ${ }^{146}$ After quoting this verse, he comments 'as the going out of a lamp is non-existence (abhäva), in that way the mind of the blessed one too was liberated'. ${ }^{147}$

Within the Abhidharmakośabhassya, the core of the debate on issues surrounding Anuruddha's stanza between the Sarvāstivāda-Vaibhāṣikas and the Sautrāntikas is grammatical. What the Sarvāstivāda-Vaibhāṣikas tried to establish by grammatical analysis was that nirvana is, as seen in Sanghabhadra's effort in the Nyāyānusāraśāstra, a real dharma existing separately from phenomenal extinction, which is likened in Anuruddha's stanza to the going out of a lamp.

First, the Sarvāstivāda-Vaibhāșikas used the genitive case to insist that nirvana is a cessation (nirodha) which is acquired through the cutting of the acquisition of defilement: ${ }^{148}$

[Vaibhāșikas] How is the genitive case understood in the sentence, 'This is the cessation of that thing (vastu)'? [Sautrāntikas] There is indeed no relationship of this [cessation] with that [thing] because there can be no state of being related as the result of a cause and the like. But mere negation, 'the non-existence of that', is applicable! [Vaibhāșikas] The cessation (nirodha) that is acquired through the cutting of the acquisition of defilement, even in another existence, is designated as 'of that [thing]'. [Sautrāntikas] In that case, what is the cause of limitating the acquisition of that [thing]? [Vaibhāșikas] The sütra talks about 'a monk who has attained nirvana in the present life'. ${ }^{149}$ In that case how could he have the acquisition of non-existence? [Sautrātikas] It is said that nirvana is attained through acquiring the basis (äsraya), which completely prevents the arising of defilement and future life, by acquiring an antidote.

Since a defilement exists in the three time periods in the SarvāstivādaVaibhāșika system, its cessation is done by cutting, or technically 'disjoining' (visamyoga), its connection with a series of aggregates (skandhasamtāna) through the power of knowledge ( pratisamkhy $\bar{a}$ ). As a result of this cutting there arises 'the acquisition of disjunction' (visamyogapräpti), which serves as an antidote (pratipakșa) to prevent perpetually the reconnection between that defilement and this series. ${ }^{150}$

Within the Sarvāstivāda-Vaibhāșika system, 'ceasing a defilement' could only be possible by the arising of a dharma, 'the acquisition of disjunction', against the defilement; as a consequence, there are no more activities, arising, 
duration, decay and ceasing, of that defilement in this series. This dharma is the Sarvāstivāda-Vaibhāṣika's equivalent of nirvana and is explained as 'cessation (nirodha) that is acquired through the cutting of the acquisition of defilement'. Thus, this cessation exists separately from defilement (kleśa) in this system. In other words, cessation is one thing and defilement is another in the compound 'the cessation of defilement' (kleśanirodha).

By contrast, 'destroying a defilement' in the Sautrāntika system could only be done by destroying the corresponding latent defilement (anuśaya), which is in the state of seed (bija), that is to say, the power (śakti) of a series of aggregates (skandhasamtāna) to produce this defilement in the future, a power that has been conveyed through the causal relationship between a moment and the immediately preceding moment. ${ }^{151}$ As said above, this kind of Sautrāntikan causal relationship cannot be established between cessation and defilement and thus this compound, 'the cessation of defilement', can only mean mere negation, i.e. the non-existence of that defilement.

Stopping the conveyance of a power to produce defilement in the future means that the Sautrāntika equivalent of 'the cessation of defilement' is future non-arising of a defilement. The obvious question put forward by the Sarvāstivāda-Vaibhāṣika will be, 'How can one acquire cessation, or nirvana, at the present time?' That is to say, how could we know whether a certain defilement is destroyed by destroying the corresponding latent defilement?

The answer from the Sautrāntikas was, as seen before, that it could be done by changing the support (áśraya), the series of aggregates, from a normal state of having a power to produce a defilement in the future to a special (viśeșa) state of lacking that power to produce a defilement. ${ }^{152}$ Therefore there is no need for the Sautrāntikas to accept a separate dharma apart from defilement in the compound 'the cessation of defilement' (kleśanirodha).

Second, the Sarvāstivāda-Vaibhāṣikas used the locative case to insist that nirvana as non-appearance exists separately: ${ }^{153}$

[Vaibhāșikas] Why do you not want to interpret as 'because it does not appear in that, it is non-appearance'? [Sautrāntikas] We do not consider this locative case possible. [Vaibhāșikas] What is meant? [Sautrāntikas] If when one says 'It does not appear in that [nirvana]' it is further meant that 'that [nirvana]' exists, then it would follow that attachment permanently does not appear, since nirvana is permanent. When one says, then, 'obtained', that is to say, 'that [nirvana] was obtained' is referred to, you should admit 'the nonappearance of suffering' when the noble path is attained. ${ }^{154}$

Under the influence of the Buddhist theory of momentariness, ${ }^{155}$ the concept of nirvana was changed dramatically: it prefers non-arising to cessation or extinction. When saying momentary dharma, it means that this dharma is in the state of arising, duration, decay and ceasing constantly. Ceasing simply 
means immediately following a new arising. Nirvana should be different from this kind of constant ceasing and is, thus, achieved only by the stopping of the new sequence of arising, duration, decay and ceasing. This is why non-arising is paradoxically preferred as the meaning of nirvana by later Buddhists: the Theravādins ${ }^{156}$ and the Sautrāntikas. ${ }^{157}$

What the Sarvāstivāda-Vaibhāṣikas tried to establish here was a link between the word non-appearance, which is the same as non-arising above, and 'the acquisition of disjunction' (visamyogapräpti), their equivalent of nirvana, with the locative case. In this system, 'the acquisition of disjunction' works as an antidote (pratipaksa) to prevent perpetually the reconnection between a certain defilement and a series of aggregates (skandhasamtāna). If there is 'the acquisition of disjunction', which works against a certain defilement in a series of aggregates, there is non-appearance of that defilement in the series of aggregates. That is to say, this dharma, 'the acquisition of disjunction', exists separately from non-appearance of a certain defilement.

The objection from the Sautrāntikas is that such non-appearance of a certain defilement is obtained not by a separately existing dharma, the acquisition of disjunction' that arises as a result of cutting the junction of the defilement through the power of knowledge, i.e. the noble path, but directly by the presence of the noble path. Although this locative case was defended by Vasubandhu in this way, it was actually a weak argument. In fact the Sarvāstivāda-Vaibhāṣika's argument using this locative case seems to have been sustained by Candrakīrti in the Prasannapadā, the commentary on Mülamadhyamakakārikāa. ${ }^{158}$ This may be why Vasubandhu quoted Anuruddha's stanza to defend the Sautrāntika position.

There are three counterarguments in the Nyāyannusāraśāstra against Vasubandhu's use of Anuruddha's stanza. In the first, his tactic was to show other sūtras that support the Sarvāstivāda-Vaibhāșika position on nirvana, while accepting briefly the negative meaning of Anuruddha's stanza. It reads as follows: $:^{159}$

Masters of Abhidharma have already gone through these texts. In other words, when one says the cessation of suffering (duhkha), the meaning is of two kinds: there is no separate entity apart from suffering and there is a separate entity apart from suffering. The Buddha saw various mental dispositions of those who are to be trained (vineya). That is why he taught two different meanings of cessation. He sometimes taught that there is no separate entity; for example, in the two sütras mentioned above. ${ }^{160}$ By contrast, he sometimes taught that there is a separate entity, for example, in the sütra saying there is certainly a place where there is no birth; the sütra saying there is a sphere (äyatana) and there is an escape (nihsarana); the sütra saying I saw that there really is a thing (padârtha), the unconditioned (asamskrta), that is to say nirvana; and the sütra 
saying that cessation is spoken of only by reason of the cessation of five aggregates as fuel. The sütras of these kinds are so numerous that our system cannot be contradicted by the holy teaching.

Although we cannot identify all the sütras mentioned by Sanghabhadra, the first two sütras mentioned here to support the view that there is a separate entity apart from suffering (duhkha) seem to be the suttas in the Udāna in the Pali Khuddakanikāya, ${ }^{161}$ which have been quoted by modern scholars to insist that nirvana cannot be mere non-existence.

The Chinese translation of the interpretation of Anuruddha's stanza by Xuan-xang reads slightly differently yet shows what the point in this simile is: 'Just as the going out of a lamp could only be regarded as the extinction of fire without any separate existent (dravyāntara), in that way the liberation attained by the mind of the blessed one is only the extinction of all aggregates. ${ }^{162}$ That is to say, it is about whether there can be a separate entity apart from the going out of a lamp or not. If there is a separate entity apart from the lamp's going out, as argued by the Sarvāstivāda-Vaibhāṣikas, we can say that nirvana is a real existent existing separately from the mere cessation of the aggregates. By contrast, if there is no separate entity apart from the lamp's going out, as argued by the Sautrāntikas, we can say that nirvana is not a real existent existing separately but is the mere cessation of all aggregates.

The first alternative was taken by Sanghabhadra to defend the SarvāstivādaVaibhāṣika position in the second counterargument in the Nyāyānusāraśästra:

In addition, the going out of a lamp is mentioned in the sütra because there is a separate entity apart from the lamplight, that is to say, the characteristic of impermanence (anityatālakșana). How the example given by the [Sautrāntikas] can be contradicted [by us] by this meaning! Moreover, even if there is no separate entity, it is not non-existence. It is due to the fact that all conditioning factors (samskāra) have the characteristic of impermanence (anityatālakșana). Its intrinsic nature (svabhāva) is not nonexistence. By considering this, there is no fault [in our system]. ${ }^{163}$

Sanghabhadra here presents two possible explanations to support the Sarvāstivāda-Vaibhāșika's position. His explanation depends heavily on the fully developed form of the Sarvāstivāda dharma theory.

In the first argument, he insisted that there can be a separate dharma apart from the lamplight and that is the characteristic of impermanence (anityatälakșana), which is one of four characteristics, arising, duration, decay and ceasing, and is one of the fourteen dharmas not associated with mind (cittaviprayuktasamskāra). Within the Sarvāstivāda system, a dharma in which these four characteristics are found is a conditioned dharma, while 
THE DOCTRINAL DEVELOPMENT OF NIRVANA

Table 5.3 Eight characteristics arising with a conditioned dharma

\begin{tabular}{|c|c|c|c|c|}
\hline dharma & \multicolumn{4}{|c|}{ A conditioned dharma } \\
\hline lakșana & Arising & Duration & Decay & Ceasing \\
\hline anulakșana & $\begin{array}{c}\text { arising of } \\
\text { arising }\end{array}$ & $\begin{array}{c}\text { duration of } \\
\text { duration }\end{array}$ & $\begin{array}{c}\text { decay of } \\
\text { decay }\end{array}$ & $\begin{array}{c}\text { ceasing of } \\
\text { ceasing }\end{array}$ \\
\hline
\end{tabular}

a dharma in which they are not found is an unconditioned dharma. ${ }^{164}$ Since the lamplight is a conditioned dharma, there must be four characteristics existing separately from this lamplight.

However, this argument given by Sanghabhadra cannot be sustained even from his own ontological position. Since these four primary characteristics (lakșana), arising, duration, decay and ceasing, which arise with a conditioned dharma such as lamplight, are also conditioned dharmas, they also have in their turn four secondary characteristics (anulakșana). ${ }^{165}$ These secondary characteristics, which are already sixteen in number, also have in their turn four characteristics and in this way arises an infinite regress.

The Sarvāstivāda-Vaibhāṣika's answer to this dilemma was that secondary characteristics (anulakșana) arising together with a conditioned dharma and four primary characteristics are not sixteen but four in number, as in the case that a hen lays many eggs and each egg causes the birth of only one other chicken. ${ }^{166}$ Their view is summarised in Table 5.3.

Whether this awkward explanation of the Sarvāstivāda-Vaibhāṣika was accepted by the Sautrāntikas or not, Sañghabhadra's first explanation could not be sustained. Although the characteristic of impermanence (anityatālakșana) can be said to exist separately from lamplight, it is just one of either eight primary (lakșana) and secondary (anulakșaṇa) characteristics according to the Sarvāstivāda-Vaibhāșika system, or of infinite characteristics according to their definition of conditioned dharmas. That is to say, Sanghabhadra's comparison cannot really fit Anuruddha's simile.

His second argument utilised the relationship between the intrinsic nature (svabhāva) of a dharma and its activities: arising, duration, decay and ceasing. ${ }^{167}$ That is to say, the going out of a lamplight is only one of the activities of the lamplight's intrinsic nature (svabhāva), which exists in the three time periods. The Sarvāstivāda-Vaibhāṣikas, thus, can say that just as lamplight has an intrinsic nature apart from its activity of ceasing, so there is nirvana existing separately from the cessation of the aggregates. However, this argument cannot be sustained from the Sautrāntika ontological perspective, since there is no difference between the intrinsic nature (svabhāva) of a dharma and its activities and as a consequence what changes momentarily is the dharma itself. ${ }^{168}$

Although we cannot easily determine the validity of these two arguments, since they are based on their own ontological perspectives, we can still 
examine which argument represents the original meaning of the image of a fire extinguished in the context of the Tathāgata after death. ${ }^{169}$ As seen before, the image represents a fire's going out due to lack of fuel and is different from a fire image seen in the early Upanișads. The latter predicates that when a phenomenal fire is extinguished, the essential character (linga) of fire is not extinguished but hidden in its latent state, ${ }^{170}$ which could be the origin of the so-called Indian view suggested by F. Otto Schrader. ${ }^{171}$

The second argument put forward by Sanghabhadra seems to be based more on the Upanișadic image of a fire than on the image of a fire extinguished in the context of the Tathägata after death. Although the Buddha seems to have argued precisely against this kind of Upanisadic view in his dialogue with Vacchagotta, ${ }^{172}$ its influence on Buddhism is apparent from the position taken by Sanghabhadra's second argument. By contrast, the Sautrāntika argument explained by Xuan-zang ${ }^{173}$ specifically represents the original meaning of the image of a fire extinguished in the context of the Tathägata after death. ${ }^{174}$ When he says that the fire goes out through lack of fuel, fuel refers to the five aggregates, as is clearly pointed out by his saying 'the liberation attained by the mind of the blessed one is only the extinction of all aggregates'.

What is the position taken by the Theravāda exegetical tradition on this simile? ${ }^{\text {?5 }}$ Although its initial interpretation of Anuruddha's stanza seen in the Theragathāatthakath $\bar{a}^{176}$ confirms that the fire goes out through lack of fuel, its quotation of the Parayana stanza at the end of the clarification seems to suggest wanting to keep open the possibility of interpreting nirvana not as mere non-existence. As seen in Chapter 4, nirvana for the later Theravāda exegetical tradition is cessation consisting in non-arising, and exists separately ( pätiyekka) from the mere destruction of passion, hatred and delusion. ${ }^{177}$ The Sammohavinodanī, the commentary on the Vibhanga, summarises this later position of the Theravādins as follows:

And when it is said in the exposition of the mental sphere, 'What is here the unconditioned element? It is the cessation of passion, the cessation of hatred, and the cessation of delusion'; this means that the unconditioned element is nirvana whose intrinsic nature is unconditioned. But because passion etc. cease on coming to this [nirvana], it is said, 'It is the cessation of passion, the cessation of hatred, and the cessation of delusion.' This is the teachers' common explanation of this matter. ${ }^{178}$

What has been said here is that the cessation of passion, hatred and delusion is only a phenomenon that appears on the attainment of nirvana, which itself exists separately ( $p$ âtiyekka) from this mere destruction.

As seen before, they quote the unidentified sutta to support this position: 'thus ignorance and craving, on coming to this, are destroyed in this, are 
abolished in this, nor do they do anything anywhere'. ${ }^{179}$ The use of the locative case in this quoted sutta could be closely linked to that of the Sarvāstivāda-Vaibhāșikas seen above. They use the locative case to explain that nirvana, or non-appearance, exists separately from the cessation of defilements, which was likened to the going out of a lamp in the Anuruddha's stanza.

Although it is slightly different, a similar interpretation is found in the last counterargument put forward by Sanghhabhadra in the Nyāyānusāraśāstra. In this counterargument, he said: 'This sütra ${ }^{180}$ only represents the moment of entering nirvana without a remainder of clinging (nirupadhiśeșanirvānad$h \bar{a} t u)^{\prime} .{ }^{181}$ That is to say, he regarded this final extinction that was likened to the going out of a lamp as a phenomenon that appears only at the moment of the final liberation, whereas nirvana itself is a real existent separate from this phenomenon.

One thing in common in both approaches that refuse to see nirvana as mere non-existence is that such mere destruction is only a phenomenon appearing at the moment of attaining nirvana. Their concept of nirvana, however, is quite different: for instance, nirvana for the Theravādins is the one and only unconditioned, ${ }^{182}$ while for the Sarvāstivāda-Vaibhāṣikas there are as many nirvanas as there are possible connections to impure dharmas. ${ }^{183}$

Table 5.4 shows briefly the developments of the nirvana concept and the two nirvana theory in terms of the differences between schools seen so far. 


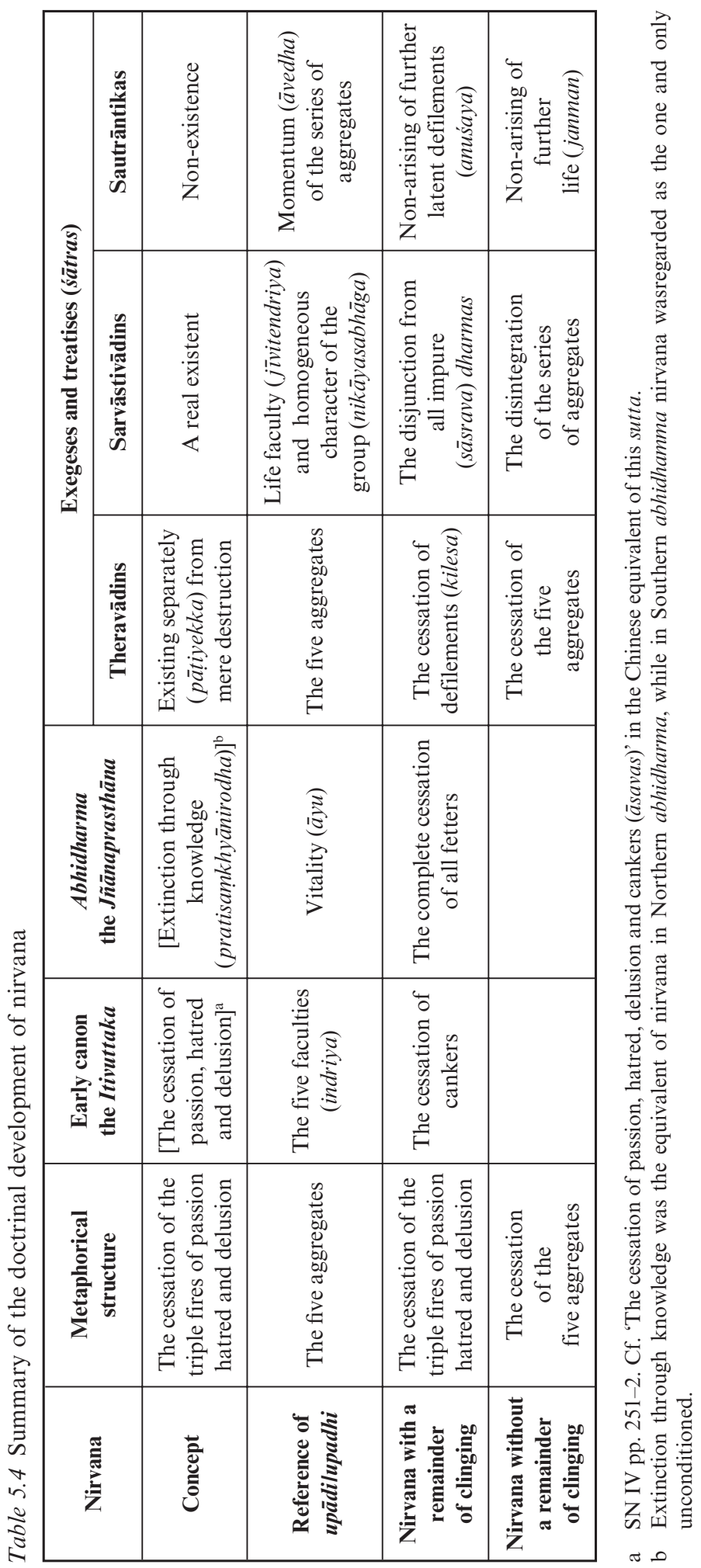




\section{6 \\ CONCLUSION}

We have traced the early doctrinal history of the nirvana concept and the two nirvana theory that depended on the image of a fire extinguished, while challenging two seemingly solid opinions that seem to be outcomes of the lack of comprehensive understanding of nirvana and its metaphorical structure. The first opinion was related closely to the interpretation of nirvana with a remainder of clinging, while the second opinion was associated with the state of nirvana without a remainder of clinging, the state of the Tathāgata after death.

First, what clinging (upādilupadhi) refers to is supposed to differentiate between nirvana with a remainder of clinging (sa-upādisesanibbānadhātul sopadhiśeșanirvānadhātu) and nirvana without a remainder of clinging (anupādisesanibbānadhātu/nirlan-upadhiśeșanirvāṇadhātu), yet 'attachment', the generally accepted reference of the word, could not make that distinction, because there is no more attachment or defilement left in either nirvana during life or nirvana at death.

Although there is little trace left in the early canon, this problem can be solved if we consider 'fuel', the objective meaning of the word upādi or upadhi, which seems to have been used to refer to the five aggregates in a metaphorical structure that embraces Enlightenment and its opposite. ${ }^{1}$

However, if we simply assemble quotations we may easily arrive at a different conclusion: ${ }^{2}$ nirvana with a remainder of clinging could not originally mean enlightenment or sainthood (arahant), but meant non-returner (anāgämin), a state in which there still were some attachments left (saupādisesa) to be perfected, and as a consequence the two nirvana theory was initially referred to the state of non-returner and saint. Not only did this confusion occur among modern scholars; it had already been recorded in one of the sütras in the Chinese Ekottara-āgama. ${ }^{3}$ Although it is not yet clear whether this sütra was accepted within the mainstream Buddhist schools, this sütra seems to be the earliest sign of unintentional literalism even within the early canon (sūtra).

The close relationship between the non-returner and the saint (arahant) could be another example of the Buddhist reaction against the Upanișad. 
The term anāgämin was often replaced in the early canon with the expression 'of a nature not to return from that world' (anāvatti-dhammo tasmā lokā) ${ }^{4}$ which refers to 'liberation' in the early Upanișads. ${ }^{5}$ That is to say, this term seems to have been used as a kind of metaphor for the lay equivalent of the renunciate saint.

When the word clinging (upadhi) was interpreted later in the Mahāvibhasșáśăstra, the objective meaning of the word, the fuel of a fire underlying the five aggregates in a metaphorical structure, seems to have been long forgotten, while defilement, the widely circulated meaning of the word, could not satisfy the masters of the abhidharma because it did not differentiate between the two nirvanas. The Sarvāstivāda-Vaibhāșikas ended up by introducing 'birth body' (janmakāaya) as a new referent for 'with a remainder of clinging' (saupadhiśeșa). ${ }^{6}$ Although it can differentiate between the two nirvanas, this interpretation could only be justified through their own abhidharma system.

Second, ever since the state of the Tathägata after death became one of the unanswered questions, there have been numerous attempts to fill 'the silence of the Buddha' by gathering relevant passages in the early canon (sütra). Most plausible claims so far have been made through clarifying the image of a fire extinguished, either from the Brahmanic or from the Buddhist sources. The argument depends largely on the logic that to the Buddha's audience this image could not have appeared as annihilation, as it does to modern eyes equipped with the image of scientific combustion. Those equipped with the allegedly common Indian view, which could be traced back to the Upanișads, ${ }^{7}$ may have thought that a fire when extinguished does not really go out but goes back into a non-manifested or invisible state. Some scholars accordingly have insisted that the state of Tathägata after death could not be any kind of annihilation. What has been lacking in this apparently solid argument seems to have been attention to the methodological and historical context of the image of a fire extinguished, especially as used in the dialogue between the Buddha and Vacchagotta. ${ }^{8}$

Unlike in the Upanișadic methodology, where things were explained through the hierarchical relationship between essence and phenomenon, or subject within and object outside, the Buddha explains things according to their causes (yoniso manasikarra). That is to say, he explains things through the causal relationship between phenomena and, as a consequence, there is no room for any essence, like Brahman, or subject, like ätman, that is beyond the range of this causality. Behind this allegedly common Indian view, there is a hierarchical relationship between the imperishable essential character $(\text { linga })^{9}$ and phenomenal fires. When the Buddha asked Vacchagotta, 'This fire that has gone out in front of you, in which direction - to the east, west, north or south - has it gone from here?, ${ }^{10}$ he seems to have been arguing specifically against such a view by asking how we could justify anything beyond the range of phenomenal causality. 
The intended deduction from this image of a fire extinguished was, as seen in Chapter 3, that just as it goes out through lack of fuel, there will be no more rebirth due to lack of cause. As far as the early canon (sütra) was concerned, this much could be the best possible account of the state of the Tathägata after death, or nirvana without a remainder of clinging, according to the Buddha's method, yoniso manasikāra.

This does not mean there was no influence at all on Indian Buddhism from the above Upanișadic view. The Sarvāstivādins were unique in insisting on the existence of all dharmas in the three time periods, while accepting the momentariness of conditioned dharmas. Two apparently irreconcilable views were reconciled by saying that what changes momentarily is not the intrinsic nature (svabhāva) of a dharma but its activities: arising, duration, decay and ceasing. Although the Sarvāstivādins explain things through the horizontal relationship between dharmas, the relationship between the intrinsic nature of a dharma and its activities seems to be hierarchical. This became apparent when Sangabhadra used this relationship to explain the existence of a separate dharma behind the lamp's going out in the last stanza of the Anuruddha's verse. ${ }^{11}$ In fact there is little difference between the intrinsic nature (svabhāva) and the imperishable essential character (linga) in terms of their relation to phenomenal fires.

Even in this case, the Sarvāstivādin interpretation of nirvana without a remainder of clinging, or the state of the Tathaggata after death, was quite different from the Upanișadic liberation. It is, as seen in Chapter 5, the disintegration of the series of aggregates. ${ }^{12}$ Thus, the whole picture of nirvana cannot be revealed, as seen in these two opinions, without considering its metaphorical and historical contexts together with its early developments in the abhidharma as well as its later developments among Buddhist schools.

Although the explanations of nirvana in the early canon (sütra) were contingent (ābhiprāyika), explanations in the abhidharma were definitive (läkșanika). This abhidharmic trend continued in the exegeses and treatises that represent specific Buddhist schools, so let us compare each Buddhist school's position on the concept of nirvana and the two nirvana theory.

Although there is no text left to explain systematically what the Sautrāntika's two nirvana theory is, we can still reconstruct their possible position from the scattered interpretations seen in the Abhidharmakośabhāsya in comparison with the Sarvāstivāda-Vaibhāșika position. Comparing three major Indian Buddhist schools' opinions can reveal the whole development of the concept of nirvana. It also allows us to observe whether the Sautrāntikas really revitalized the forgotten value of nirvana's early metaphorical contexts. That is to say, are they, the Sautrāntikas, worthy of their name, the followers of the sütras? As seen in Table 5.4, their positions on the nirvana concept and the two nirvana theory were different according to school. Although they seem to have known the basic definition of nirvana, the cessation of 
passion, hatred and delusion, they all abandoned this definition in due course owing to the doctrinal development of their abhidharma systems.

Despite developing other explanations of the word nibbanna, ${ }^{13}$ the Theravādin was perhaps the only school that made an effort within its abhidhamma to retain its original value: this definition was applied not only to nirvana but also to the one and only unconditioned. However, at the end it became a fragile spot in their positive interpretation of nirvana and was challenged by the disputants (vitandavädins). ${ }^{14}$ Their solution was to devalue this definition as referring to a temporary phenomenon that appears on one's going to (tam a gamma) nirvana. ${ }^{15}$ Thus, nirvana for them existed separately (pätiyekka) from the mere extinction of passion, hatred and delusion, and on this point the Theravādins were not alone: the Sarvāstivādins insisted that the cessation, like the going out of a lamp, appeared only at the moment of entering nirvana without a remainder of clinging (nirupadhiśeșanirvānadhātu). ${ }^{16}$

For the Sarvāstivādins, the word nirvāna is not in their list of seventy-five dharmas that exist in the three time periods. Extinction through knowledge (pratisamkhyanirodha), one of the three unconditioned dharmas, is their equivalent of nirvana. Part of the reason why they use a different name for their nirvana concept seems to be its application: while nirvana in the early canon was applied to the extinction of all defilements represented by the triple fires of passion, hatred and delusion, extinction through knowledge was applied to the single perpetual separation of an impure dharma from a series of aggregates. This could be the reason why the above basic definition of nirvana appeared only as one of ten explanations of the word nirvāna. ${ }^{17}$

In this respect, the state of nirvana within the Sarvāstivāda tradition was interpreted positively: it is a real existent (dravya) that exists in the three time periods. However, this does not mean, as mentioned above, that this interpretation can be applied to the state of the Tathägata after death, which is the disintegration of the series of aggregates. When the series of aggregates has disintegrated, personal identity no longer continues, even if dharmas that constitute that series of aggregates continue to exist.

Under the influence of the Buddhist theory of momentariness, the nirvana concept seems to have changed: it prefers non-arising to cessation or extinction. Since a momentary dharma is constantly arising, enduring, decaying and ceasing, ceasing or extinction simply means that a new arising follows immediately. Non-arising in this case means the stopping of any new sequence of arising, duration, decay and ceasing. All three schools in fact accepted this change and used it to strengthen their abhidharmic systematisation. The Theravādins used it to support their positive interpretation of nirvana by saying that nirvana is 'cessation consisting in non-arising, ${ }^{18}$ whereas the Sarvāstivādins used it to reinforce their equivalent of nirvana, extinction through knowledge, by saying 'the cessation (nirodha) that is acquired through the cutting of the acquisition of a defilement'. ${ }^{19}$ 
The Sautrāntikas were among the most enthusiastic to utilise this change. In fact they applied it to their definition of nirvana: 'the extinction through knowledge is that, when latent defilements (anuśaya) and life (janman) that have already been produced are extinguished, non-arising of further by the power of knowledge ( pratisamkhyā) ${ }^{20}$ Their interpretation of the state of nirvana, or the state of the Tathägata after death, was negative: for them, nirvana is not a real existent (dravyasat) but a mere designation (prajñaptisat), something spoken of conventionally, and is 'non-existence succeeding existence' ( paścādabhāva), like a sound that is non-existent before and will be non-existent after its occurrence. ${ }^{21}$

Although their definition of nirvana agrees with their ontological position, it is far away from its original definition: the cessation of the triple fires of passion, hatred and delusion. However, their understanding of 'with a remainder of clinging', the core of interpreting the two nirvana theory, came close to what we have seen in the metaphorical structure of nirvana in the early canon (sūtra).

While the Theravādin interpretation seems to retain its metaphorical usage, the 'fuel' of a fire underlining the five aggregates, the Sarvāstivādin interpretation seems to be the outcome of their systematisation. Vitality (āyu) first appeared in one of their seven abhidharma texts, the Jñänaprasthāna. ${ }^{22}$ Vitality $(\bar{a} y u)$ seems to have been used first in the context of nirvana without a remainder of clinging and only then applied to nirvana with a remainder of clinging. Later in the Mahāvibhāsasaśästra, it was interpreted as both the life faculty (jivitendriya) and the homogeneous character of the group (nikāyasabhāga), purely due to their abhidharmic systematisation. ${ }^{23}$

The possible position of the Sautrāntikas can be deduced from their criticism of both the life faculty (jivitendriya) and homogeneous character $($ sabhägatā). The former was interpreted as a name given to the momentum (avedha) initiated by action (karma) in the series of aggregates at the moment of conception, while the existence of the latter was denied. Although this interpretation came from the Sautrāntikas' criticism based on their ontological perspective, their reference for the word upadhi, the momentum of a series of aggregates, could at least come close to its metaphorical reference: the five aggregates.

Because the Buddha was silent on the question of the state of the Tathaggata after death, we cannot say whether their negative interpretation of nirvana really represents the intention of the Buddha seen in the early canon (sütra). However, their use of the image of a fire extinguished, as in Anuruddha's last stanza, did agree with what was said in the dialogue between the Buddha and Vacchagotta. That is to say, they did not accept the existence of a separate dharma behind the lamp's going out. In this respect, their understanding of the image of a fire extinguished could be a lot closer to its original meaning within the early canon (sütra) than the Sarvāstivādin understanding, which was almost like the Upanișadic image of a fire extinguished. 
The Sautrāntikas probably knew the diverse nature of the early canon and represented the meaning of the early canon better than the Sarvāstivādins. However, this does not mean they are worthy of their name, the followers of the sütras. As seen in Chapter 5, they were not determined to revitalise the value of the early canon (sütra), but instead used the early canon to defend their extreme ontological position and to argue against their opponents, such as the Sarvāstivāda-Vaibhāṣikas.

This attitude may further explain Vasubandhu's later introduction of the Mahāyāna concept of latent consciousness (älayavijñanna) in his Karmasiddhiprakarana, which seems to have been composed before his conversion to the Yogācāra school. His priority seems to have been not to go back to the teachings of the early canon but to protect or to complete their own extreme ontological position.

As noted in the Introduction, the Yogācāra school insisted on three ${ }^{24}$ or possibly four ${ }^{25}$ nirvanas. The task of comparing these nirvanas with the traditional two nirvana theory requires further understanding of relevant Mahāyāna materials from the doctrinal and historical perspectives. I hope the current study may serve as the foundation for further study of the Mahāyāna concept of nirvana and their equivalent of the two nirvana theory. 



\section{Part 2}

\section{ANNOTATED \\ TRANSLATIONS OF THE RELATED TEXTS IN PALI, SANSKRIT AND CHINESE}





\section{SELECTED SOURCES FOR THE NIRVANA CONCEPT AND THE TWO NIRVANA THEORY}

\section{The unconditioned element (asankhata dhätu) in the Sammohavinodani ${ }^{1}$}

And when it is said in the exposition of the mental sphere ${ }^{2}$ that "what is here the unconditioned element? It is the cessation of passion, the cessation of hatred, and the cessation of delusion', ${ }^{3}$ this means that the unconditioned element is nibbāna whose intrinsic nature is unconditioned. But because passion etc. cease on coming to this $[$ nibbāna $],{ }^{4}$ it is said that 'it is the cessation of passion, the cessation of hatred, and the cessation of delusion'. This is the teachers" common explanation of this matter.

But a disputant (Vitaṇụāandin) has said: 'There isn't anything existing separately called nibbāna. Nibbāna is just the cessation of the defilements.' And when he is asked to quote a sutta, he quotes the Jambukhädaka-sutta: ${ }^{6}$ 'It is said, o frienḍ Sāriputta, nibbāna, nibbāna. Then what is indeed, o friend, nibbāna? The cessation of passion, the cessation of hatred, and the cessation of delusion, o friend, that is indeed called nibbanna', and says 'Through this sutta it should be understood that there isn't anything existing separately called nibbāna. Nibbāna is just the cessation of the defilements.'

He should be asked 'But is there meaning as there is this sutta?' ${ }^{8}$ Surely he will say, 'Yes, there is no meaning apart from a sutta'. ${ }^{9}$ Then, he should be asked 'Now you have quoted this sutta. Quote the next sutta.' 'The next sutta ${ }^{10}$ says that "It is said, o friend Sāriputta, sainthood (arahant), sainthood. Then what is indeed, o friend, sainthood? The cessation of passion, the cessation of hatred, and the cessation of delusion, o friend, that is indeed called arahatship".' This is the sutta immediately following. But when this one has been cited, they say to him that 'The dhamma called nibbāna is a dhamma that is included in the mental sphere. Sainthood is the four [mental] aggregates. The general of the dhamma, Sāriputtạ who had witnessed nibbāna and dwelt there, when asked about nibbanna and about sainthood, said that it is just the cessation of the defilements. But are nibbāna and sainthood the same thing or different things?' 
'Let it be the same or different. What is the use of your grinding so exceedingly fine?' 'You don't know whether it is the same or different.' 'But surely it is good if that is known!' Being repeatedly asked such questions, he is unable to play tricks and says 'Sainthood is called the destruction of passion, hatred, and delusion because it arises at the end of the cessation of passion etc.' Then to him they say 'You have done a great work. Even by giving a bribe ${ }^{11}$ one is getting you to say, he would get you to say just this. And just as you have said this by making a distinction, so you should notice this [next remark]. Nibbāna is said to be the cessation of passion, the cessation of hatred, and the cessation of delusion, because passion etc. ceases on coming to nibbāna. All these three are terms for nibbāna alone.'

[The refutation continues in this form on the following subjects: 'plurality of nibbāna', 'grossness', 'Change of Lineage (gotrabhü)' and 'the Noble Eightfold Path', and finally the disputant (Vitaṇavāadin) asked the kernel of the problem.]

This has been said, he (the disputant) says: 'You say "on coming to, on coming to". From where have you got this [word] called on coming to?' 'It is taken from a sutta. ${ }^{12}$ 'Quote the sutta.' 'Thus ignorance and craving, on coming to this, are destroyed in this, ${ }^{13}$ are abolished in this, nor do they do anything anywhere. ${ }^{, 14}$ When this was said, the other speaker (the disputant) became silent.

\section{The exegesis of the two nirvana theory in the Mahāvibhāsāśästra}

\section{Introductory comment}

According to the early canon (sütra), there are two nirvana elements: nirvana with a remainder of clinging (sopadhiśeșanirvānadhätu) and nirvana without a remainder of clinging (nirupadhiśeșanirvānadhātu) and so on. ${ }^{16}$

Question: Why is this discourse composed [by the author of the Jñānaprasthāna]?

Answer: It is to clarify the complete meaning of the early canon (sütra). Although the early canon (sütras) says that there are two nirvana elements: nirvana with a remainder of clinging and nirvana without a remainder of clinging, it does not fully explain their meaning. Thus, 'what is nirvana with a remainder of clinging?' and 'what is nirvana without a remainder of clinging?' were fundamental questions for that treatise. ${ }^{17}$ Since they are not clarified [in the early canon], they are explained [in the Jñänaprasthāna].

Alternatively, we have seen above [in the Jñannaprasthāna] that "what is extinction through knowledge (pratisamkhyannirodha)? It is all extinction which is disjunction (visamyoga). ${ }^{31}$ Although this disjunction is nirvana, nirvana is of two kinds: with a remainder of clinging (sopadhiśeșa) and 
without a remainder of clinging (nir/an-upadhiśeșa). ${ }^{19}$ The author [of the Jñanaprasthāna] here wants to establish the difference between the two.

Alternatively, it is to refute other systems' opinions and to establish the correct theory. That is to say, [1] some say wrongly that nirvana with a remainder of clinging should be regarded as a real existent while nirvana without a remainder of clinging should not. The author refutes this opinion and makes clear that both nirvana elements should be regarded as a real existent. [2] Some say wrongly that the first is impure while the second is pure. The author refutes this opinion and makes it clear that both nirvana elements are pure. [3] Some say wrongly that the first is a conditioned thing while the second is an unconditioned thing. The author refutes this opinion and makes it clear that both nirvana elements are unconditioned things. [4] Some say wrongly that the first is good while the second is indefinable. The author refutes this opinion and makes it clear that both nirvana elements are in nature good. [5] Some say wrongly that the first is the path (mārga) while the second is the result of the path. The author refutes this opinion and makes it clear that both nirvana elements are the result of the path. [6] Some say wrongly that the first is the result of the path while the second is not. The author refutes this opinion and makes it clear that both nirvana elements are the result of the path. [7] Some say wrongly that the first is included in the noble truths (satyasamgrhita) while the second is not. The author refutes this opinion and makes it clear that both nirvana elements are included in the noble truths. [8] Some say wrongly that the first is aśaikșa while the second is naivaśaikșanāśaikșa. The author refutes this opinion and makes it clear that both nirvana elements are naivaśaikșanásaikșa. For every reason mentioned above, the author [of the Jñannaprasthāna] made this discourse.

\section{Nirvana with a remainder of clinging}

What is nirvana with a remainder of clinging (sopadhiśeșanirvānadhātu)? A saint (arahant) has completely extinguished his impurity (kșināsrava); his vitality (āyus) alone exists; the series of primary elements (mahābhütāni) and secondary matter (upādàyarūpa) have not yet become extinct; the mental series supported by the five faculties is active as there is still a remainder of clinging. The complete cessation of all fetters (samyojana) which is obtained ( präpta), possessed (pratilabdha), touched (sprșta), and realised (sākșatkrta) [by this Arahant] is what is called nirvana with a remainder of clinging. ${ }^{20}$

When saying vitality, the life faculty (jīvitendriya) ${ }^{21}$ is meant here.

Question: Why is the homogeneous character of the group (nikāyasabhāga) ${ }^{22}$ not mentioned? 
Answer: The author [of the Jñanaprasthāna] intended to do so and so on.

Alternatively, it is not mentioned as that meaning is surely known from the word 'with a remainder' (sa-śesa).

Alternatively, both the life faculty and homogeneous character are the result of action that projects existence (äksepakakarman) ${ }^{23}$ As the life faculty is exclusively maturation (vipa $k a$ ), $\mathrm{it}^{24}$ is mentioned alone here [in the Jñānaprasthāna].

Depending on 'with a remainder', form (rüpa) and mind (citta) and so on are active (pravrtti). As they have primary elements as their support, it is mentioned here first. From these primary elements, secondary matter is formed. From the secondary matter, mind (citta) and mental states (caitta) arise. As mind is a chief, it is mentioned alone here [in the Jñanaprasthāna]. ${ }^{25}$

'Primary elements and secondary matter' altogether designate the material body (rūpakāya), while 'the mental series supported by the five faculties' designates mind (citta) and mental states (caitta).

Moreover there are the characteristics of arising and so on. ${ }^{26}$ They are not explained here since they are difficult to understand and they depend on the previous dharma.

The complete cessation of all fetters (samyojana) is obtained while the series of all dharmas ${ }^{27}$ becomes extinct. That is why it is called nirvana element with a remainder of clinging.

According to an opinion, primary elements and secondary matter are body $(k \bar{a} y a)$, the five faculties are faculty (indriya) and the mental series is intellect (buddhi). The complete cessation of all fetters (samyojana) is obtained while the series of body, faculty and intellect becomes extinct. That is why it is called nirvana with a remainder of clinging. In this respect an early canon (sütra) says, 'As body, faculty and intellect becomes extinct it is called nirvana element with a remainder of clinging.'

When saying 'as there still is a remainder of clinging', clinging is of two kinds: the clinging as defilement (kleśopadhi) and the clinging as birth body (janmakāyopadhi). ${ }^{28} \mathrm{~A}$ saint (arahant) no longer has the first, clinging as defilement, but he still has the second, clinging as birth body. Alternatively, clinging is of two kinds: defiled (klișta) clinging and undefiled clinging. As a saint (arahant) no longer has the first while he still has the second, the complete cessation of all fetters (samyojana) is called nirvana with a remainder of clinging. The terms, obtained ( präpta), possessed ( pratilabdha), touched (sprsțta) and realised (sākșătkrta), are different literally, but they are used in the same sense.

\section{Nirvana without a remainder of clinging}

What is nirvana without a remainder of clinging (anupadhiśeșanirvāna- dhātu)? A saint (arahant) has completely extinguished his impurity (kșingāsrava); his vitality (äyus) has come to an end; the series of primary elements 
(mahābhütāni) and secondary matter (upādāyarūpa) has already been destroyed; the mind supported by the five faculties is no longer active as there is no remainder of clinging. The complete cessation of all fetters (samyojana) is what is called nirvana without a remainder of clinging. ${ }^{29}$

When saying 'vitality has come to an end', it means that both the life faculty and homogeneous character of the group (nikāyasabhäga) have already been destroyed, since both are the result of action that projects existence (ākssepakakarman). By saying the life faculty, moreover, one should know that it also implies homogeneous character.

'The series of primary elements and secondary matter have already become extinct' means that the series of material body has already been destroyed, while 'the mind $\mathrm{d}^{30}$ supported by the five faculties is no longer active' means that the series of mind and mental states are no longer active.

It does not mention the characteristics of arising and so on. The reason is the same as before.

According to an opinion, primary elements and secondary matter are body $(k \bar{a} y a)$, the five faculties are faculty (indriya) and the mental series is intellect (buddhi). The material body, the mind and mental states or the series of body, faculty and intellect have already become extinct. The complete cessation of all fetters (samyojana) is called nirvana element without a remainder of clinging.

When a saint (arahant) is about to enter the state of nirvana (parinirvānakāle), wind ${ }^{31}$ in his body becomes an unhealthy condition (kalya). From the unhealthy condition, the internal fire weakens. From the weakening, food cannot be digested. From the indigestion, desire for food does not arise. Without desire for food, no more food is taken. Without food, the primary element is deteriorated (vipatti). From the deterioration, secondary matter and all faculties are also deteriorated. From the deterioration of faculties, mind and mental states no longer have their support ${ }^{32}$ and thus no longer continue. Without the continuation of mind and mental states, the life faculty and so on $^{33}$ become destroyed. From the extinction of vitality and so on, he enters nirvana.

When saying 'as there is no remainder of clinging', no [remainder of] clinging is of two kinds: no clinging as defilement (kleśopadhi) or no clinging as birth body (janmakāyopadhi). Alternatively, [no remainder of clinging is of two kinds:] no defiled (klista) clinging or no undefiled clinging. As there is no remainder of clinging, the complete cessation of all fetters is called nirvana without a remainder of clinging.

Question: Why is 'obtained (prāpta), possessed (pratilabdha), touched (sprșța) and realised (sākșātkrta)' not mentioned here?

Answer: 'Obtained and so on' is used with reference to present acquisition ( $p r a \bar{p} t i$ ). It is not used when present acquisition ceases. Alternatively, 'obtained 
and so on' is conventionally designated (prajñapti) in respect of a person (pudgala). There is no person but dharma in itself (dharmatā) in [nirvana without a remainder of clinging] $;{ }^{34}$ it is not mentioned here.

\section{Discussions of the two nirvana theory}

Question: Can anyone admit that a saint (arahant) resides neither in nirvana with a remainder of clinging nor in nirvana without a remainder of clinging $?^{35}$

Answer: It is impossible by reasoning, yet it is possible from the definitions given here. According to them, it is nirvana with a remainder of clinging when all three things are present, whereas it is nirvana without a remainder of clinging when one of three things is not present. [1] For a saint who is born in the world of formlessness, he does not reside in nirvana with a remainder of clinging since he cannot have a material body. As his mind is active, he does not reside in nirvana without a remainder of clinging. [2] For a saint who is born in the world of form and has entered the absorption of extinction (nirodhasamäpatti), he does not reside in nirvana with a remainder of clinging since his mind is not active. As there is a material body, he does not reside in nirvana without a remainder of clinging. [3] For a saint who is born in the world of desire but lacks his faculty, he does not reside in nirvana with a remainder of clinging since he cannot have the five faculties. As he has a material body he does not reside in nirvana without a remainder of clinging.

There is an opinion. ${ }^{36}$ The text should be written as follows: what is nirvana with a remainder of clinging? The complete cessation of all fetters (samyojana) is obtained (prāpta), possessed (pratilabdha), touched (sprșta) and realised (sākșätkrta) by a saint while his vitality (äyus) alone exists. What is nirvana without a remainder of clinging? A saint whose vitality has already come to an end ceases all fetters completely.

In this way, when a saint is born in one of three worlds, whether he has a material body or not, whether his mind is active or not, whether he has the five faculties or not, he resides in nirvana with a remainder of clinging if his vitality exists. He resides in nirvana without a remainder of clinging if his vitality has come to an end. Although it should be written in this way, it is not written. That is why the author of this treatise ${ }^{37}$ gave this opinion for the sake of all disciples to understand [the two nirvana theory] easily.

Question: When disjunction (visamyoga) is attained by a prthagjana or śaikșa, which nirvana elements does it belong to ${ }^{38}$

Answer: It does not belong to either of the two nirvana elements. [1] When disjunction is attained by a prthagjana, it can only be called abandoning 
(prahāna), detachment (virāga), cessation (nirodha) and noble truth (satya). However, it cannot be called the complete knowledge (parijña $\overline{\text { ), the result }}$ of religious life (śramanyaphala), nirvana with a remainder of clinging, or nirvana without a remainder of clinging. [2] When disjunction is attained by a śaikșa, it can only be called abandoning, detachment, cessation and noble truth. It can be called the complete knowledge and the result of religious life in some cases, while it cannot in other cases. However, it cannot be nirvana with a remainder of clinging, or nirvana without a remainder of clinging. [3] When disjunction is attained by an aśaikșa, it can only be called abandoning, detachment, cessation, noble truth, the complete knowledge and the result of religious life. In a certain moment it can be called nirvana with a remainder of clinging. In a certain moment it can be called nirvana without a remainder of clinging.

\section{The debate on nirvana in the Abhidharmakośabhāṣa ${ }^{39}$}

[Vaibhāșikas] Then if nirvana is only non-arising, how are we to interpret this statement in the sütra: ${ }^{40}$ "these five faculties if practised, cultivated and developed conduce to the abandonment of past, future and present suffering'? As nirvana is abandonment and is the non-arising only of future, is it not of past and present? ${ }^{41}$

[Sautrāntikas] This is true. ${ }^{42}$ However, the abandonment of suffering is caused by the abandonment of the defiling passions towards their objects: ${ }^{43}$ the blessed one said 'Abandon desire and passion for form (rupa). When desire and passion have been abandoned, then what is form will be abandoned by you and comprehended [by you. The same is said in turn of feeling, apperception, mental formations] and consciousness. ${ }^{44}$ In this way, the abandonment of suffering in all three times is applicable.

[Vaibhāșikas] Then, could one say 'to the abandonment of past, future and present defilement'?

[Sautrāntikas] Here also the interpretation is the same. Alternatively this is the intention: past defilement would be of former lives and present defilement would be of the present life, just like the eighteen speculations of craving among the speculations of craving: ${ }^{45}$ 'in view of past time' is said with regard to past life, and the same with regard to present [life].

And by the two kinds [past and present] of defilements, the state of being seed ${ }^{46}$ is planted in this series to arise in future. Through the abandonment of that [seed], that [defilement] too is abandoned. In the same way that through exhausting maturation (vipāka), action is exhausted. Further, abandonment is the absolute non-arising of future suffering or defilement because of the absence of the state of being seed (bijabhāva). Otherwise what of past and present defilement is there to be abandoned? Indeed, there is no profit in 
making an effort concerning what has already ceased and what is on the point of ceasing. ${ }^{47}$

[Vaibhāṣikas] While the blessed one said 'some dharmas are conditioned and some unconditioned, detachment is called the best of them', ${ }^{48}$ if unconditioned things simply do not exist, how can there be a non-existence best of non-existent things?

[Sautrāntikas] We do not say that 'the unconditioned does not exist at all'. This is, however, such a thing in the way we said. For example, it is said that 'there is prior non-existence of sound' and 'there is non-existence after its occurrence'.

Moreover, the existence of the non-existence is not proved. The unconditioned should also be seen in that way. And a certain non-existence becomes the most commendable thing; that is to say, the absolute non-existence of all trouble. It should receive praise as the highest thing of all in order to enamour trainees of it.

[Vaibhāṣikas] If unconditioned things were mere non-existence, [the third noble truth of] cessation would not be a noble truth. ${ }^{49}$ For are you saying that that [truth] is nothing?

[Sautrāntikas] What is, then, the meaning of truth? Surely meaning what is not contradicted. ${ }^{50}$ And both these uncontradicted things have been seen by the noble ones that suffering is suffering and that the non-existence of suffering is non-existence. How does this contradict the fact that these are noble truths?

[Vaibhāșikas] How could something be called both non-existence and the third noble truth?

[Sautrāntikas] It is said that it was seen and taught immediately after the second, so it becomes the third.

[Vaibhāṣikas] If unconditioned thing is mere non-existence, the consciousness that has space or nirvana as its object would have non-existence as its object.

[Sautrāntikas] We will be concerned with this when we are dealing with the existence of past and future. ${ }^{51}$

[Vaibhāṣikas] But if when is unconditioned were considered as a real existent (dravya), what would happen?

[Sautrāntikas] Well, what would happen? 
[Vaibhāṣikas] The Vaibhāṣikas' opinion would be protected.

[Sautrāntikas] If protection is the concern, gods will protect it (the Vaibhāșikas' opinion). Moreover, it would be falsely imagined.

[Vaibhāṣikas] Why is that?

[Sautrāntikas] Because neither is an intrinsic nature (svabhāva) perceived, like the form (rīpa), feeling and the like, nor is an activity perceived, like that of the eye and the like. ${ }^{52}$

[Vaibhāṣikas] How is the genitive case understood in the sentence, 'This is the cessation of that (vastu)'? $?^{53}$

[Sautrāntikas] There is indeed no relationship of this [cessation] with that [thing] because there can be no state of being related as the result of a cause and the like. But mere negation, 'the non-existence of that', is applicable!

[Vaibhāșikas] The cessation that is attained through the cutting off of the acquisition of defilement, even in another existence, is designated as being of that [thing]. ${ }^{54}$

[Sautrāntikas] In that case, what is the cause of limiting the acquisition of this [thing]?

[Vaibhāșikas] The sūtra talks about 'A monk who has attained nirvana in the present life'. ${ }^{55}$ In that case how could he have the acquisition of nonexistence?

[Sautrātikas] It is said that nirvana is attained through acquiring the basis $(\overline{a s} r a y a)^{56}$ that prevents completely the arising of defilement and future life, by acquiring an antidote.

Moreover, an $\bar{a} g a m a^{57}$ shows clearly that it is mere non-existence. It indeed says thus: 'That which is entire abandonment, relinquishment, coming to an end, exhaustion, detachment, cessation, tranquillization, disappearance of [even] the smallest suffering, and non-connection, non-arising, nonappearance of other suffering, that is lovely, that is excellent - that is to say, abandonment of all conditions, perishing of desire, detachment, cessation, nirvana.'

[Vaibhāșikas] Why do you not want to interpret it as 'because it does not appear in that, it is non-appearance'? 
[Sautrāntikas] We do not consider this locative case possible.

[Vaibhāṣikas] What do you mean?

[Sautrāntikas] If when one says 'It does not appear in that [nirvana]' it is further meant that 'that [nirvana]' exists, then it would follow that attachment permanently does not appear, since nirvana is permanent.

When one says, then, 'obtained', that is to say, 'that [nirvana] was obtained' is referred to, you should admit 'the non-appearance of suffering' when the noble path is or attained. ${ }^{58}$ [In other words, the non-appearance of suffering is obtained by a separately existing dharma called nirvana, but by the presence of the noble path.] And this simile is thus well adduced. 'Like the going out of a lamp, his mind becomes liberated. ${ }^{59}$ As the going out of a lamp is nonexistence (abhāva), in that way the mind of even the blessed was liberated. ${ }^{60}$

\section{The interpretation of Anuruddha's verse in the Nyāyānusāraśāstra}

In addition, you should admit that nirvana is mere non-existence from the following well explained sütra: 'His mind was liberated like the going out of a lamp.' The [Sautrāntikas] think that as the blowing out of a lamp should only be admitted as the extinction of fire without any separate entity, the liberation attained by the mind of blessed one is only the extinction of all aggregates without any [separate entity].

\section{The first counterargument}

Masters of Abhidharma have already gone through these texts. In other words, when one says the cessation of suffering $(d u h k h a)$, the meaning is of two kinds: there is no separate entity apart from suffering and there is a separate entity apart from suffering. The Buddha saw various mental dispositions of those who are to be trained (vineya). That is why he taught two different meanings of the cessation. He sometimes taught there is no separate entity: for example, the two sătras mentioned above. ${ }^{62}$ By contrast, he sometimes taught there is a separate entity: for example, the sütras saying there is certainly the place where there is no birth; the suttras saying there is sphere (äyatana) and is escape (nihsarana) ${ }^{63}$; the sütras saying I saw that there really is a thing (padārtha), the unconditioned (asamskrta), that is to say nirvana; and the sütras saying the cessation is said only by reason of the cessation of five aggregates as fuel. The sütras of these kinds are so numerous that our system cannot be contradicted by the holy teaching.

\section{The second counterargument}

In addition, the going out of a lamp is mentioned in the sütra because there is a separate entity apart from the lamplight; that is to say, the characteristic of 
impermanence (anityatālakșana). How the example given by the [Sautrāntikas] can be contradicted by this meaning! Moreover, even if there is no separate entity, it is not a non-existence. It is due to the fact that all conditioning factors (samskära) have the characteristic of impermanence (anityatālakșana). Its intrinsic nature (svabhāva) is not a non-existence. ${ }^{64}$ By considering this, there is no fault [in our system].

\section{The third counterargument}

The sütra mentioned above cannot be enough to establish that the going out of a lamp is mere non-existence. The sütra only represents the moment of entering nirvana without a remainder of clinging (nirupadhiśesanirvānadhātu). ${ }^{65}$ Thus, it is to inform people of the fact that there is a cutting without a remainder of all clinging through abandoning one by one and so on. Thus, there is no contradiction. 


\section{NOTES}

\section{INTRODUCTION}

1 Akb-h pp. 133, 185, 235, 331, 333. Also see Sa-d p. 254, Sa-w p. 172.

$2 \mathrm{Mv}$ (TD27 403a): 問諸有漏法能為 因義皆是集諦. 何故世尊但説集諦是愛非餘.

3 Vin I p. 10, MA (TD1 468b).

4 SA (TD2 88b).

5 tasmād ābhiprāyikaḥ sūtreșu nirdeśo lākșaṇikas tv abhidharme, Akb-h p. 333.

6 See also 'Upädisesa within the context of nirvana' in Chapter 2.

7 See La Vallée Poussin (1923: 908-10).

8 Gombrich (1996: 65).

9 Gombrich (1996: 21).

10 The Buddhist Nirvāna and Its Western Interpreters by Guy Richard Welbon.

11 Cousins (1999: 373).

12 Vibh pp. 72-3, 89, SN IV pp. 251-2.

13 Dhs pp. 74-5, 116-17. Also see BD pp. 24-5, 119.

14 DN I p. 156, II p. 92, MN I pp. 465-7, AN II p. 238.

15 Gombrich (1996: 66).

16 Gombrich (1996: 67).

17 Lamotte (1973: 8).

18 La Vallée Poussin (1928: 670-1).

19 Oldenberg (1882: 427-45).

20 Lovejoy (1898).

21 Masefield (1979).

22 EA (TD2 579a).

23 BUCD, CSCD and PTSCD.

24 SLTP.

25 CETSCD.

26 Schrader (1905: 167-70).

27 Harvey (1990: 66-7).

28 DN II p. 157, MN I pp. 487-8, SN I p. 159, AN I p. 236, AN IV p. 3, Th p. 84, Thī p. 116, Sn pp. 41, 206 and so on.

\section{NIRVANA AND ITS REFERENCE}

1 'We know what nirvāna is as well as the Buddhists themselves did, and it is not our fault if we are not able to give an unambiguous statement. The Buddhist felt satisfied with a description which does not satisfy us, because, whereas we have been for centuries trained to make our ideas clear, this was not the case with the 
Indians; and also because we look at the Buddhist doctrines from the outside, without in the least believing in them: whereas nirvāna is for us a mere object of archaeological interest, it is for Buddhists of paramount practical importance. Our business is to study what nirvanna may be; the business of a Buddhist is to reach nirvāna - a very different thing.' ERE p. 376.

2 He suggested nir $\sqrt{ } v r$ (to cover) from the fact that nibbuta (sk. nirvrta), the past participle of $n i r \sqrt{ } v r$, is widely used in the meanings, such as extinguished (of fire), cooled, quenched, desireless, appeased, pleased and happy (PED pp. 362, 366).

3 The root $v \bar{a}$ takes the suffix -na either for the past passive participle or to make adjectives and nouns. There seems to be in Pali no example yet discovered of nibbāna or parinibbāna used as a past passive participle or an adjective (Collins 1998: 195).

4 Ñyāṇamoḷi (1976: 319 note 72).

5 Norman (1993: 221-3).

6 Thomas (1927: 187).

7 MN I p. 140, SN III p. 109, see also Thomas (1933: 125-6).

8 Although 'the idea that nibbāna applies to an experience in life whereas parinibbāna applies to the experience at death is widespread', the latter is in fact just the synonym of the former and the difference between the two is simply a grammatical one: 'pari compounded with a verb converts the verb from the expression of a state to the expression of the achievement of an action', and thus the former is 'the state of release'; the latter is 'the attaining of that state' (Norman 1993: 216-17).

9 I discuss this in detail in 'Upādisesa within the context of nirvana' in Chapter 2.

10 Thomas (1933: 123).

11 ERE 7, p. 468 (quoted from Thomas 1933: 119).

12 For the difference between Jainism and Buddhism. See 'Upādisesa within the context of nirvana' in Chapter 2.

13 Zaehner (1973: 10).

14 Tr. from Edgerton (1952: 57). '24 Yo 'ntahsukho 'ntarārāmas tathā 'ntarjyotir eva yah sa yogī brahmanirvānạn brahmabhūto 'dhigacchati. 25 Labhante brahmanirvānam rsṣayah kșinakalmașāh chinnadvaidhā yatātmānah sarvabhütahite ratāh. 26 Kāmakrodhaviyuktānām yatīnām yatacetasām abhito brahmanirvānạn vartate viditātmanām.'

15 Zaehner (1973: 159, 212-14).

16 Zaehner (1973: 214-15).

17 See 'Upādisesa within the context of nirvana' in Chapter 2.

18 Gombrich (1988: 63).

19 Gombrich (1996: 65).

20 Vin I pp. 34-5, SN IV p. 19.

21 See 'Upädisesa within the context of nirvana' in Chapter 2.

22 Gombrich (1996: 66).

23 Schumann (1989: 87).

24 SN IV pp. 251-2.

25 Vibh pp. $72-3$, Vibh p. 89.

26 See also 'The Pali abhidhamma works' in Chapter 3.

27 SN IV pp. 251-2.

28 SA (TD2 126b).

$29 \mathrm{Mv}$ (TD27 147b): 問以何義故名日涅槃. 答煩惱滅故名為涅槃. 復次三火息故名 為涅槃. 復次三相寂故名為涅槃. 復次離臭穢故名為涅槃. 復次離諸趣故名為涅 槃. 復次槃名稠林. 涅名為出. 出蘊稠林故名涅槃. 復次槃名為織. 涅名為不. 以不 織故名為涅槃. 如有縷者便有所織. 無則不然. 如是若有業煩惱者便織生死. 無學 
無有業煩惱故不織生死. 故名涅槃. 復次槃名後有. 涅名為無. 無後有故名為涅槃. 復次槃名繫縛. 涅名為離. 離繫縛故名為涅槃. 復次槃名一切生死苦難. 涅名超度. 超度一切生死苦難故名涅槃. See also Mv (TD27 163a-b): 'Question: why is extinction through knowledge (pratisamkhyānirodha) is also called nirvana? Answer: vāna means destiny (gati) and nir means exit. As it is the absolute exit from all destinies, it is called nirvana. Väna means bad odor (durgandha) and nir means negation. As being absolute without all bad smelling action (karma) and defilements (kleśa), it is called nirvana. Vāna means forest and nir means absolute separation. As being absolutely separated from the forest of the aggregates covered with all triple fires and three characteristics, it is called nirvana. Văna means weaving and nir means negation. As being absolutely without action (karma) and defilements (kleśa) one does not have to be woven into life and death through the result of maturation (vipāka). This is why it is called nirvana.'

30 Collins (1998: 195-6).

31 vānạ̣ vuccati tạnhā. sā tattha natthi ti nibbānam, Vibh-a 314 (tr. Collins 1998: 195).

32 It-a I 164, II 107. See Collins (1998: 195).

33 Dhp-a III 424.

34 See also this chapter, note 29.

35 Spk I 196 (tr. Collins 1998: 196).

36 Vism p. 242 (tr. Ñyāṇamoli 1976: 248).

\section{THE TWO NIRVANA THEORY IN THE EARLY CANON}

1 See Oldenberg (1882: 437), Lovejoy (1898: 133-4) and Norman (1993: 215).

2 Vism p. 438, Norman (1993: 215-16), Gombrich (1996: 65). See also 'The Theravāda exegetical tradition' in Chapter 3.

3 Th-a I p. 46, Dhp-a II p. 163.

4 Th-a I p. 46, Dhp-a II p. 163.

5 PED p. 247, Masefield (1979: 217).

6 Oldenberg (1882: 427-45).

7 Lovejoy (1898).

8 Masefield (1979).

9 In AN IV pp. 74-9, two kinds of a saint, ubhatobhāgavimutta and pañ̃̄āvimutta are described as anupādisesa, while kāyasakkhin, ditțippatta, saddhāvimutta, dhammānusārin and animittavihārin are described as saupādisesa. In AN IV pp. 379-81, five sub-divisions of non-returner, i.e. antarāparinibbāyin, upahaccaparinibbāyin, asaìkhāraparinibbāyin, sasaìkhāraparinibbāyin and akanitthagāmin; a once-returner (sakadāgāmin); and three kinds of streamenterer (sotāpanna), i.e. ekabïjin, kolamkola and sattakkhattuparama are described as saupādisesa.

10 In the early canon, añ̃̃a is sometimes used where the word arahant is expected (MN I pp. 445, 465, 466, SN II p. 224). See also BD p. 17, Horner (1936: 161), Katz (1982: 19-20).

11 One of two fruits is to be expected: perfect knowledge (añña) in this very life, or if there is a remainder of clinging (upādisesa), the state of non-return (dvinnam

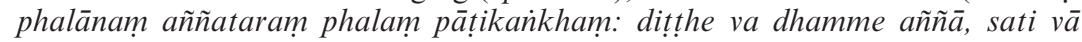
upādisese anāgāmitāa DN II p. 314, MN I pp. 62, 63, 481, SN V pp. 129, 181, 236, 313, AN III pp. 82, 143, AN V p. 108, It pp. 39, 40, 41). This passage was used as major textual evidence by Oldenberg (1882: 435), Lovejoy (1898: 134) and Masefield (1979: 221).

12 Masefield (1979: 224). 
13 Huzita (1988: 8).

14 La Vallée Poussin (1925: 168-80).

15 Thomas (1927: 190-1).

16 Gombrich (1996: 65).

17 Modern scholars tend to agree on this point. See Cone (2000: 482) and Lovejoy (1898: 134).

18 PED p. 149.

19 evañhi so bhikkhave mahā aggikkhando tadāhāro tadupādāno ciram dīgham addhānam jaleyya, SN II, p. 85 (tr. Mrs Rhys Davids in PTS edition).

20 Dhs pp. 212-13. Also see BD p. 228.

21 Such scholars as Böhtlingk, Childers and Rhys Davids regard upadhi as the Pāli representative of Skt. upädhi, which is a technical term in the Nyāya and in the Sämkhya, where it signifies the elements of phenomenal existence (Lovejoy 1898: 134) or, particularly in Indian logic, 'a condition with the help of which an invalid argument may turn valid' (Hidenori 1966: 436).

22 CPD p. 453.

23 PED p. 142.

24 Sn 33-4 (tr. Norman 1992: 4): 'nandati puttehi puttimā, iti Māro pāpimā gomiko gohi tath'eva nandati, upadhì hi narassa nandanā, na hi so nandati yo nirüpadhi.' 'socati puttehi puttimā, iti Bhagavā gomiko gohi tath'eva socati, upadhī hi narassa socanā, na hi so socati yo nirūpadhì ti.'

25 Norman (1992: 144).

26 CPD p. 453.

27 SN II pp. 108-9.

$28 \mathrm{Mv}$ (TD 27 168a). See 'The development of the two nirvana theory in the Mahāvibhāșāśāstra' in Chapter 5.

29 Salomon (1999: 28).

30 Salomon (1999: 110-27).

31 Salomon (1999: 128).

32 AN IV pp. 379-81.

33 See this chapter, note 20.

34 Vin I pp. 34-5, SN IV p. 19.

35 Gombrich (1996: 65), PED p. 433.

36 ābhiprāyiko hi sūtranirdeśah, no lākșanikah, yathā abhidharmah (Sa-d p. 254, Saw p. 172). Also see Akb-h pp. 133, 185, 235, 331, 333.

37 Part of the reason why a fire image is used could be that his audience had practised the fire cult (jatilas); he wanted to make 'a deep impression on them to hear fire spoken of in this profound philosophical sense' (Schumann 1989: 87).

38 sabbam bhikkhave ādittam. kiñca bhikkhave sabbam ādittam? cakkhum bhikkhave ädittam. rūpā ādittā. cakkhuviñ̃̄annam ädittam. cakkhusamphasso āditto. yam p' idam cakkhusamphassapaccayā uppajjati vedayitam sukham vā dukkham vā adukkhamasukham vā, tam pi ādittam. kena ädittam? rāgagginā dosagginā mohagginā ādittam. jātiyā jarāya maranena sokehi paridevehi dukkhehi domanassehi upāyāsehi ādittan ti vadāmi, Vin I p. 34, SN IV pp. 19-20.

39 'The fires number three because the Buddha was alluding to a set of three fires which the brahmin householder was committed to keeping alight and tending daily, so that they came to symbolise life in the world, life as a family man', Gombrich (1996: 66).

40 See Table 2.1, p. 22.

41 SN III p. 71.

42 Ñyāṇamoḷi (1960: 214-15). 
43 Ñyāṇamolii (1962: 26 note 78/2).

44 MN II pp. 256-60.

45 Oldenberg (1882: 436-7) in fact used this simile to prove that the word upādi has a moral sense, like fetters, rather than a physical sense, i.e. the aggregates.

46 ... sallam abbaheyya apaneyya visadosam sa-upādisesam anupādiseso ti mañ̃ãāāno . . . apanīto visadoso anupādiseso, analañ ca me antarāyāti . . MN II p. 257.

47 Gombrich (1996: 68-9), Norman (1993: 215).

48 The Ben-shi-jing (本事經: TD17 667-8).

49 katamā bhikkhave saupādisesā nibbānadhātu? idha bhikkhave bhikkhu araham hoti khịnāsavo vusitavā katakaran̄īyo ohitabhāro anuppattasadattho parikkhīnabhavasamyojano sammadaññ̄ivimutto. tassa tițthanteva pañcindriyāni yesam avighātattā manāpāmanāpam paccanubhoti, sukhadukkham pațisamvediyati. tassa yo rāgakkhayo dosakkhayo mohakkhayo, ayam vuccati bhikkhave saupādisesā nibbānadhātu. katamā ca bhikkhave anupādisesā nibbānadhātu? idha bhikkhave bhikkhu araham hoti khīn̄āsavo vusitavā katakaran̄ìyo ohitabhāro anuppattasadattho parikkhịnabhavasamyojano sammadañ்̃àvimutto. tassa idheva bhikkhave sabbavedayitäni anabhinanditāni sìtibhavissanti, ayam vuccati bhikkhave anupādisesā nibbānadhātu. It p. 38 (consulted and rearranged from the translation of Harvey 1995: 180-1).

50 Huzita (1988: 8).

51 SN IV pp. 19-20. In the Adittapariyāya, all six faculties are mentioned as the sermon is applied to ordinary monks, whereas in this case, only the sense faculties are mentioned as it is applied to a saint who has achieved a firm control of his mind.

52 Gombrich (1988: 64).

53 See Norman (1993: 214).

54 Typically stated as 'birth is destroyed, the holy life is fulfilled, what should be done is done, there is no more [birth] in this world' (SN II p. 22, III pp. 45, 53, 71, 90, 224, IV pp. 2, 3, 20, 24, 26 etc.).

55 pițthi me āgilāyati tam aham āyamissāmīti, SN IV p. 184.

56 SA (TD2: 71c9, TD2: 87c-88a). For more information, see Lamotte (1988: 60, 110 note 80$)$.

57 cakkhum ca pațicca rūpe ca uppajjatti cakkhuviñ̃ānam: tịnnam samgati phasso; phassapaccay à vedanā, vedanāpaccayā tanhā . . (MN III p. 282, SN II pp. 72-5, SN IV pp. 32-3, 87, 90).

58 MN I pp. 111-12. For more information see Kalupahana (1992: 32-4).

59 yạ̣ vedeti tạ̣ sañjānāti, yam sañjānāti tam vitakketi, yam vitakketi tạ̣ papañceti, MN I pp. 111-12.

60 Hamilton (2000: 30).

61 Hamilton (2000: 78).

62 Masefield (1979: 218).

63 Bronkhorst (1986: 95).

64 cetanāham bhikkhave kammam vadāmi; cetayitvā kammam karoti kāyena vācāya manasā, AN III p. 415. Peter Harvey takes cetanā to mean 'will' so that it will be translated as 'It is will that I call action. Having willed, one acts through body, speech or mind.'

65 See Bronkhorst (1986: 31).

66 Horner (1936: 64-74).

67 In general, see BD pp. 23-6.

68 AN IV pp. 379-81.

69 AN IV pp. 74-9. 
70 See Dutt (1960: 252-71), Lamotte (1988: 611-20), Katz (1982: 83-95) and Guenther (1974: 195-215).

71 See Gombrich (1996: 96-134), Guenther (1974: 231-2).

72 I am largely following Dutt (1960: 252-71), Katz (1982: 83-95) and BD.

73 Whether this is the highest of the puthujjana or the lowest of noble persons is still problematic. See Dutt (1960: 253-4), Katz (1982: 92-3).

74 The spiritual faculties are five: faith, energy, mindfulness, concentration and insight.

75 According to Gombrich (1996: 107-10) these two terms originally refered to the same person. Also see Katz (1982: 93).

76 The pure faculties (anāsavaindriyā) are anañ̃āataññassāmītindriya, aññindriya, and añnātāvindriya. See Horner (1936: 161-77).

77 Katz (1982: 94) regards kolankola and ekabïjin as sub-categories of a oncereturner (sakadāgāmin).

78 In the Abhidharmakośabhāṣya, antarāparinirvāyin is interpreted as 'one who obtains nirvana in the intermediate existence' (La Vallée Poussin 1923: 966). For antarāparinibbāyin, see Somaratne (1999: 121-54).

79 In the Abhidharmakośabhāsya, upapadyaparinirvāyin is interpreted as 'one who obtains nirvana immediately after being reborn' (La Vallée Poussin 1923: 966).

80 For these two releases, see Gombrich (1996: 110-34).

81 The old list of the seven noble persons can be found in MN I p. 477. See also Gombrich (1996: 96-107).

82 Ñyāṇamoḷi (1976: 770). The Abhidharmakośabhāṣya (La Vallée Poussin 1923: 966) explains them in a slightly different manner. See also Guenther (1974: 231-2).

83 It does not mean that the person has acquired the faculty of faith only, but means that he is also under the impulse of another four faculties (La Vallée Poussin 1923: 1016).

84 In the Abhidharmakośabhāṣya (La Vallée Poussin 1923: 977-9, 1016), kāyasākșin is the one who has realised nirodhasamäpatti.

85 See this chapter, note 69.

86 AN IV (tr. Hare) p. 45 note 5. See also Gombrich (1996: 104).

87 The Abhidharmakośabhāṣya (La Vallée Poussin 1923: 1016) does not specifically mention the faculty of insight.

88 If we follow the traditional list of the seven noble persons, it could be saddhānusārin.

89 etā bhante bhikkhuniyo anupādisesā suvimuttā, AN IV p. 75.

90 AN IV p. 75 note 2 (tr. Mrs E. M. Hare in PTS edition).

91 Somaratne (1999: 126), BD pp. 24, 199.

92 BD p. 199, pp. 24-5. Also see Ñyāṇamoḷi (1960: 204 note 39).

93 See this chapter, note 20.

94 Somaratne (1999: 124-31).

95 DN I p. 156, DN II p. 92, MN I pp. 465-7, AN II p. 238.

96 Tr. Somaratne (1999: 127).

97 Dhs pp. 74-5, 116-17.

98 Pp p. 17.

99 Ds (TD26: 463c). It also shows the old explanation of a once-returner: the attenuation of passion, hatred, and delusion (Ds TD26: 465a).

100 SN V p. 200. See also SN V pp. 193-4, SN V pp. 204-5.

101 See also Katz (1982: 87).

102 SN V pp. 204-5.

103 See Table 2.2, p. 25. 
104 yato kho bhikkhave ariyasāvako imesam channam indriyānam samudayañca atthagamañca assādañca ādīnavañca nissaranañca yathābhütam pajānāti; ayam vuccati bhikkhave ariyasāvako sotāpanno ... SN V p. 205.

105 SN V p. 207.

106 yato kho bhikkhave bhikkhu imesam channam indriyānam samudayañca atthagamañca assādañca ādīnavañca nissaranañca yathābhütam viditvā anupādā vimutto hoti; ayam vuccati bhikkhave bhikkhu araham ... SN V pp. 205, 206.

107 SN V p. 208.

108 BD pp. $78-9$.

109 For the three pure faculties, see Horner (1936: 161-77).

110 Horner (1936: 161).

111 MN I p. 445, MN I pp. 465, 466, SN II p. 224.

112 SN V pp. 222-3.

$113 \mathrm{Jp}$ (TD26: 994b-c).

114 La Vallée Poussin (1923: 177-80).

115 See Table 2.2, p. 25.

116 Lovejoy (1898: 136).

117 Oldenberg (1882: 438).

118 Masefield (1979: 218-20).

119 It p. 38.

120 SN II p. 83.

121 DN III p. 135.

122 See Harvey (1995: 181).

123 Sn 354 (p. 64).

124 nibbāyi so ādu saupādiseso, tr. Norman (1992: 39).

125 yathā vimutto ti kị̣ anupādisesāya nibbānadhātuyā yathā asekhā, udāhu saupādisesāya yathā sekhā ti pucchati, Pj II 350, 23. Also see Norman (1992: 214), Masefield (1979: 222, 230).

126 Norman (1992: 214).

127 Sn p. 64 (tr. Norman 1992: 39).

128 dvinnam phalānam añ̃ataram phalam pāțikan்kham: dițțe va dhamme añña, sati vā upādisese anāgāmitā, DN II p. 314; MN I pp. 62, 63, 481; SN V pp. 129, 181, 236, 313; AN III pp. 82, 143; AN V p. 108; It pp. 39, 40, 41.

129 See Figure 2.

130 Horner (1936: 225-6).

131 MN I pp. 465-6.

132 See this chapter, note 96.

133 SN V pp. 69-70.

134 SN V p. 237.

135 SN V p. 285.

136 SN V p. 314.

137 SN V pp. 69-70.

138 Patihacca given from the PTS edition could not be the right reading since it does not make sense. It is instead pațikacca given by CSCD and BUCD to mean 'earlier, beforehand, previously'.

139 DA (TD1 75a), SA (TD2 196b).

140 AN pp. $71-2$.

141 MA (TD1 427b-c).

142 See this chapter, note 124.

143 SN V p. 285.

144 SA (TD2 196b-c).

145 See this chapter, note 49. 
146 Akanuma (1929: 126).

147 EA (TD2 579a): 有此二法涅槃界. 云何為二. 有餘涅槃界. 無餘涅槃界. 彼云何 名為有餘涅槃界. 於是. 比丘滅五下分結. 即彼般涅槃. 不還來此世. 是謂名為有 餘涅槃界. 彼云何名為無餘涅槃界. 如是. 比丘盡有漏成無漏. 意解脱. 智慧解脱. 自身作證而自遊戲. 生死已盡. 梵行已立. 更不受有. 如實知之. 是謂為無餘涅槃 界.

148 For antarāparinirvāyin see this chapter, note 78 .

149 Bareau (1966: 31).

150 Lamotte (1988: 154).

$151 \mathrm{Mv}$ (TD27 167b). See also 'The development of the two nirvana theory in the Mahāvibhāṣāśástra' in Chapter 5.

152 See 'Sarvāstivāda interpretation in the Jñānaprasthāna' in Chapter 3.

153 See the sects map in Bareau (1955: 30).

154 AN IV pp. 71-4, MA (TD1 427b-c).

155 The Mdhyama-āgama was translated by Gautama Sanghadeva and Sangharakșa between 397 and 398. In the same period, he also translated the Ekottaraàgama.

156 DN II p. 94, III pp. 5, 227; MN I p. 37; SN I p. 220, IV pp. 279, 304; AN I pp. 208, 222, II pp. 34, 56, III pp. 36, 212, 286, IV p. 406, V pp. 183, 330; It p. 88. In the Chinese àgamas, not just this technical term, si-shuang-ba-bai (四雙八輩) but all eight stages are listed (DA (TD1 13b, 37b), MA (TD1 477a, 479b, 482b, 616a, 722b), SA (TD2 143c, 145b), EA (TD2 609b, 650b, 755b, 767a, 792a, 826b)).

157 Horner (1934: 791), Horner (1936: 224).

158 BAU VI 2 15, CHU IV 15 5, VIII 15.

159 RV V 54 12, VII 66 12, X 18 4. For more, see Lévi (1937: 24-38).

160 SB II 1 34, II 149.

161 BAU VI 215 (tr. Olivelle 1996: 84).

162 CHU IV 15, 5, VIII 15.

163 Pandito, bhikkhave, Brahmāyu brāhmano; paccapādi dhammassānudhammaṃ; navamam dhammādhikaraṇam vihesesi. Brahmāyu, bhikkhave, brähmaṇo pañcannam orambhāgiyānam saṃyojanānam parikkhayā opapātiko hoti tatthaparinibbāyì anāvattidhammo tasmā lokā ti (MN II p. 146).

164 MN III p. 247.

165 SN V p. 347.

166 Harvey (2000: 91-2) has also pointed out 'one lay Non-returner, Ugga, who taught dhamma to monks if they do not themselves teach him'.

167 See this chapter, notes 104, 105, 106.

168 SN V (PTS English translation) p. 181 note 4.

169 DN II p. 91.

170 MN I pp. 465-6, DN II pp. 91-2, SN V pp. 356-8, MA (TD1 545c), SA (TD2 217b).

171 MN I pp. 462-8.

172 Horner (1934: 785).

173 Horner (1936: 64-74).

174 Horner (1934: 786), Horner (1936: 75-95).

$175 \mathrm{Mv}$ (TD 27 168a).

\section{DEVELOPMENTS OF THE TWO NIRVANA THEORY}

1 Cox (1995: 8-10), Cox (1998: 168-9).

2 For mātrkāa, see Frauwallner (1995: 3-11), Bronkhorst (1985: 305-20), Cox (1995: 8-10), Cox (1998: 168-70). 
3 DN III pp. 207-71.

4 DA (TD1 49b-52c).

5 Frauwallner (1995: 14).

6 Dhs pp. 192-3, Vibh p. 89, Dhātuk p. 7. See also Bareau (1951: 23-9).

7 Cousins (1983: 98).

8 MN III p. 63. It is also seen in DN III p. 274.

9 Bareau (1951: 22-35).

10 katame dhammā sappaccayā? pañca khandhā - rūpakkhandho, vedanākhandho, sañ̃̄ākhandho, san்khārakkhandho, viñ̃ānakkhandho - ime dhammā sappaccayā. katame dhammā appaccayā? asaìkhatā ca dhātu-ime dhammā appaccayā (Dhs pp. 192-3).

11 Dhātuk p. 5: asañkhatam khandhato țapetvā.

12 Vibh pp. 72-3.

13 Vibh p. 89.

14 SN IV pp. 251-2.

15 Vibh pp. $72-3,89$.

$16 \mathrm{Kv}$ pp. 225-7. According to the Pali commentarial tradition, the opponents were the Mahimsāasakas and the Andhakas (Aung and Rhys Davids 1915: 136). Thus, both sects regard the two extinctions as nirvana, while only pațisankhänirodha (extinction through knowledge) is the equivalent of nirvana in the Sarvāstivāda abhidharma.

$17 \mathrm{Kv}$ p. 226: atthi dvinnam nibbānānam uccanīcatā hīnapan̄ìtatā ukkamsāuvakamso sìmā vā bhedo vā rājō và antarīkā vā ti?

18 See also Cousins (1983: 104).

19 Kv pp. 317-30.

20 EOB p. 149.

21 buddhādīnam nitthāya visesābhāvato ekā va nitthā... Vism p. 432.

$22 \mathrm{Pk}$ (TD26 723c, 766b), Mv (TD27 65b-c, 662a). I discuss the placement of the unconditioned in 'Nirvana and space in the Pali abhidharmma tradition' in Chapter 4.

23 Frauwallner (1995: 145).

24 Frauwallner (1995: 4-5, 135-47). The Theravādins also established that unconditioned elements are different from the five aggregates (Cousins 1983: 102).

25 The author of the $J u$-she-lun-ji (俱舍論記), one of the Chinese commentaries on the Abhidharmakośabhāsya.

26 Frauwallner (1995: 13), Cox (1998: 171).

27 Cox (1998: 173).

28 Frauwallner (1995: 4), Dk (TD26 614b).

$29 \mathrm{Pk}$ (TD26 692b).

30 Cox (1995: 12), Cox (1998: 173).

31 Ds (TD26 505a). It says that while conditioned things (samskrta) constitute five aggregates, unconditioned things (asamskrta) are space ( $\bar{a} k \bar{a} s ́ a)$ and two extinctions: extinction without knowledge (apratisamkhyānirodha) and extinction through knowledge (pratisamkhyänirodha), which is the same as nirvana.

32 See Frauwallner (1995: 135).

$33 \mathrm{Pk}(\mathrm{TD} 26$ 692b-c).

34 Patis II 178.

35 Ñyāṇamoḷi (1976: 317 note 68). See also Vibh-a 55.

36 Cox (1995: 12).

37 Mv (TD27 163a-b).

38 Pk (TD26 694b), Jp (TD26 923b). 
39 yah sāsravair dharmair visamyogah sa pratisaṃhyānirodhah duhkhādīnām āryasatyānām pratisaṃkhyānam pratisaṃkhyā prajñāviśeșas tena prāpyo nirodhah pratisaṃkhyānirodhah madhyapadalopād gorathavat, Akb-p p. 4.

40 Oxcart is a cart pulled by an ox. Thus the middle word 'pulled by' is said to be elided in the compound. Likewise, extinction through knowledge is extinction attained by knowledge. The middle word 'attained by' is said to be elided.

41 La Vallée Poussin (1923: 206-19).

42 This example is not found in the Abhidharmapitakas of the Sarvāstivādins but is in the Mahāvibhāṣāśāstra (Mv TD27 164b), the exegesis of the Jñānaprasthāna, and the Abhidharmakośabhāṣya (Akb-d p. 5, La Vallée Poussin (1923: 60)).

43 Cox (1995: 102-3).

44 Cox (1995: 89-92).

45 Mv (TD27 333c-334a), La Vallée Poussin (1923: 949-50).

46 I deal with this matter in detail in 'Nirvana in Northern Buddhist schools' in Chapter 5.

$47 \mathrm{Mv}$ (TD27 162a).

48 For the relationship between extinction through knowledge and two nirvana elements, see 'The development of the two nirvana theory in the Mahāvibhāṣāśāstra' in Chapter 5.

49 Lamotte (1988: 184), Cox (1995: 32).

50 Cox (1995: 32).

51 See 'The Theravāda exegetical position on nirvana' in Chapter 4.

$52 \mathrm{Jp}$ (TD26 923b): 云何有餘依涅槃界. 答若阿羅漢諸漏永盡. 壽命猶存. 大種造色 相續未斷. 依五根身心相續轉. 有餘依故. 諸結永盡得獲觸證名有餘依涅槃界. 云 何無餘依涅槃界. 答即阿羅漢諸漏永盡. 壽命已滅大種造色相續已斨. 依五根身 心不復轉. 無餘依故. 諸結永盡名無餘依涅槃界.

53 It p. 38.

54 See 'The Theravāda exegetical tradition' in this chapter.

55 Pe p. 124.

56 Pe p. 124.

57 It p. 38.

58 See 'The Theravāda exegetical position on nirvana without a remainder of clinging' in Chapter 4.

59 See 'Upädisesa within the context of nirvana' in Chapter 2.

60 See this chapter, p. 00.

$61 \mathrm{Mv}$ (TD27 p. 169b).

62 Masuda (1925: 16). See Lamotte (1988: 530).

63 Lamotte (1988: 535).

$64 \mathrm{Jp}$ (TD26 923b).

65 MN I p. 295. See also Jaini (1959: 539).

66 La Vallée Poussin (1923: 233).

67 āyu usmāca viññanam, yadā kāyam jahantimam, apaviddho tadā seti, parabhattam acetanam, SN III p. 143.

68 Although this stanza uses the word 'food for others' (parabhattam), the quoted stanza in the Abhidharmakośabhāsya (Akb-h p. 73) uses the word 'like a piece of wood' (yathā kāṣttham) which could be originated from a dialogue in the Mahāvedallasutta (MN I p. 296).

69 See 'Upādisesa within the context of nirvana' in Chapter 2.

$70 \mathrm{Mv}$ (TD27 168a). For the life faculty and homogeneous character see Cox (1995: 107-12, 125-31).

71 Th-a I p. 46, Dhp-a II p. 163.

72 Masefield (1979: 217). 
73 See this chapter, note 21.

74 Vism p. 432 (tr. Ñyāṇamoḷi 1976: 580-1).

75 See this chapter, note 46.

76 Akb-d pp. 324-5; Lamotte (1988: 611).

77 Vibh-a pp. 51-4, Ñyānamoḷi (1976: 579-80).

78 uddham pavattikhandhānam anuppādanato uppannānam ca antaradhānato, Vism p. 432.

79 The variants Kaccāna, Kaccāyana and Mahā-Kaccāyana can be disregarded (Ñyānamoli 1962: xxvii).

80 Ñyāṇamoḷi (1962: xxvii), AN I 23, SN III 9-13, AN V 46, 255.

81 Ud p. 57.

82 Ñyānamamoli (1962: xxvii-xxviii).

83 Warder (1970: 322-3).

84 Lamotte (1988: 325).

85 Ñyānamoli (1962: xxviii).

86 Ñyāṇamoli (1962: x), Lamotte (1988: 188-9, 325, 425).

87 Ñyāṇamoḷi (1962: xxv), Lamotte (1988: 188).

88 yā nittaṇhātā ayạ̣ saupādisesā nibbānadhātu. bhedā kāyassa ayam anupādisesā nibbānadhātu, Nett p. 38.

$89 \mathrm{Mv}$ (TD27 169a).

90 ettāvatā bhikkhu katakicco bhavati. esā sopādisesā nibbānadhātu. tassa àyupariyādānā jivitindriyassa uparodhā idañca dukkham nirujjhati, añ̃añca dukkham na uppajjati. tattha so imesam khandhānam dhātu-āyatanānam nirodho vūpasamo aññesañca khandhadhātu-āyatanānam appațisandhi apātubhä̀vo, ayam anupādisesā nibbānadhātu (Pe p. 124).

$91 \mathrm{Jp}$ (TD26 923b).

$92 \mathrm{Mv}$ (TD27 168a), Cox (1995: 107-12, 125-31).

93 It p. 38.

94 uddham pavattikhandhānam anuppādanato uppannānam ca antaradhānato, Vism p. 432.

95 Sn p. 84 (tr. Norman 1992: 51).

96 samyojanakkhayantena cettha saupādisesā nibbānadhātu, jātikkhayantena anupādisesā vuttā, Sn-a II p. 410.

97 See 'Nirvana from the Sautrāntika ontological perspective' in Chapter 5.

98 parinibbutoti dve parinibbānāni kilesaparinibbānañca, yā saupādisesanibbānadhātu, khandhaparinibbānañca, yā anupādisesanibbānadhātu, Th-a I 45.

99 Dhp-a II p. 162.

100 upadhiśabdenātmaprajñaptinimittāh pañcopādānaskandhā ucyante, Mmd-p p. 519. For the compound, the five aggregates as fuel, see 'Upädisesa within the context of nirvana' in Chapter 2.

\section{NIRVANA IN THE THERAVĀDA BUDDHIST TRADITION}

1 Schrader (1905: 167-70).

2 Schrader (1905: 167).

3 '[The paramätman is like] a fire, the fuel of which has been consumed' (Śvetāśvatara Upanisad 6, 19); 'that self is pure spirit, like fire after it has burnt what it had to burn' (Nrisimhottaratāpin̄ Upanișad 2); and 'as fire for want of fuel comes to rest in its own birthplace, so for the cessation of its motions the thinking principle comes to rest in its own birthplace' (Maitrī Upanișad 6.34). See Schrader (1905: 167-8), Thanissaro (1993: 15-20).

4 AN III 340-1. 
5 Harvey (1990: 66-7).

6 DN II p. 157, MN I pp. 487-8, SN I p. 159, AN I p. 236, AN IV p. 3, Th p. 84, Thī p. 116, Sn pp. 41, 206 and so on.

7 As, p. 132, Maung (1958: 174-5).

8 kiñca bhikkhave jānato kim passato āsavānam khayo hoti: yoniso ca manasikāram ayoniso ca manasikāram. ayoniso bhikkhave manasikaroto anuppānnā c'eva āsavā uppajjanti uppannā ca āsavā na pavaḍhanti, yoniso ca bhikkhave manasikaroto anuppannā c'eva āsavā na uppajjanti uppannā ca āsavā pahīyanti, MN I p. 7.

9 kati pan'àvuso paccayā sammādițthiyā uppādāyāti. dve kho àvuso paccayā sammādițthiyā uppādāya. parato ca ghoso yoniso ca manasikāro, MN I p. 294.

10 ko ca bhikkhave āhāro anuppannassa vā satisambojjhañgassa uppādāya uppannassa vā satisambojjhañgassa bhāvanāya pāripūriya. atthi bhikkhave satisambojjhañgațthāniyā dhammāa tattha yoniso manasikārabahulīkāro ayam $\bar{a}$ āro anuppannassa vā satisambojjhangassa uppādāya uppannassa vā satisambojjhañgassa bhāvanāya pāripüriyā, SN V pp. 103-4.

11 SA (TD2 80a).

12 EA (TD2 718a).

13 Akb-x (TD29 92a).

14 Akb-x (TD29 107b), La Vallée Poussin (1923: 408).

15 SN II p. 10, SA (TD2 79c): pubbe va me bhikkhave sambodha anabhisambuddhassa bodhisattasseva sato etad ahosi. kiccham vatāyam loko āpanno jāyati ca jūyati ca mìyati ca cavati ca upapajjati ca. atha ca pan'imassa dukkhassa nissaranam nappajānāti jarāmaraṇassa. kudassu nāma imassa dukkhassa nissaraṇam paññayissati jarāmaranassāti. tassa mayham bhikkhave etad ahosi. kimhi nu kho sati jarāmaranam hoti kimpaccayā jarāmarananti. tassa mayham bhikkhave yoniso manasikārā ahu pañ̃āya abhisamayo. jātiyā kho sati jarāmaraṇạ̣ hoti jātipaccayā jarāmaranan ti.

16 Gombrich (1996: 27). For more see Gombrich (1996: 1-6).

17 Popper (1995: 31-4).

18 Gombrich (1996: 1).

19 SN II p. 10.

20 SN II pp. 12, SA (TD2 102a).

21 Warder (1970: 119-20).

22 Collins (1982: 104).

23 SN II p. 13, SA (TD2 102a): no kallo pañhoti Bhagavā avoca. āhāretīti ahạ̣ na vadāmi. āhāretīti cāham vadeyyam tatrassa kallo pañho. ko nu kho bhante āhāretīti. evañcāham na vadāmi evam mam avadantam yo evam puccheyya kissa nu kho bhante viñ̃ānāāhāro ti. esa kallo pañho. tatra kallam veyyakaranam. viññāñāhāro āyatim punabbhavābhinibbattiyā paccayo. tasmim bhüte sati saḷāyatanam salāyatanapaccayā phasso ti.

24 La Vallée Poussin (1923: 1313).

25 Ud pp. 1-5.

26 Murti (1970: 36).

27 Jayatilleke (1980: 474).

28 Jayatilleke (1980: 471).

29 Jayatilleke (1980: 471).

30 Jayatilleke (1980: 471).

31 SA (TD2 254b).

32 MN I 484, SN III 257.

33 Murti (1970: 34-8), Jayatilleke (1980: 470-6), Kalupahana (175-9).

34 Jayatilleke (1980: 475), Kalupahana (1975: 179).

35 Kalupahana (1975: 179-80). 
36 MN I p. 484.

37 MN I p. 487: sace te Vaccha purato so aggi nibbāyeyya jāneyyāsi tvaṃ: ayam me purato aggi nibbuto ti. sace me bho Gotama purato so aggi nibbāyeyya jāneyyāham: ayam me purato aggi nibbuto ti. sace pana tam Vaccha evam puccheyya: yo te ayam purato aggi nibbuto so aggi ito katamam disam gato, puratthimam vā pacchimam vā uttaram vā dakkhinam vā ti, evam puttho tvam Vaccha kinti byākareyyāsìti. na upeti bho Gotama. yam hi so bho Gotama aggi tinakațthupādānam pațicca ajali, tassa ca pariyādānā añ̃assa ca anupahārā anāhāro nibbuto t'eva saìkham gacchatīti. evam eva kho Vaccha yena rüpena tathāgatam paññāpayamāno pañ̃̄āpeyya tam rūpam tathāgatassa pahīnam ucchinnamūlam tālāvatthukatam anabhāvakatam āyatim anuppādadhammam . . .

38 See 'Buddhist methodology' in this chapter.

39 La Vallée Poussin (1923: 284).

40 See this chapter, note 23: soul (ätman) is presupposed within the question of Moliya Phagguna.

41 SN II p. 12, SA (TD2 102a).

42 SA (TD2 246a).

43 Rahula (1967: 42).

44 See 'Upādisesa within the context of nirvana' in Chapter 2.

45 SN IV pp. 399-400: alañhi te Vaccha kañkhitum alam vicikicchitum. kañkhaniye ca pana te thāne vicikicchā uppannā. saupādānassa khvāham Vaccha upapattim pañ̃̄āpemi no anupādānassa. seyyathāpi Vaccha aggi sa-upādāno jalati no anupādāno. evem eva khvāham Vaccha sa-upādānassa upapattim pañ̃̃āpemi no anupādānassā ti. yasmim pana bho Gotama samaye acci vātena khittā dūram pi gacchati. Imassa pana bhavam Gotamo kim upādānasmim pañ̃̃āpetī ti. yasmị kho Vaccha samaye acci vātena khittā dūram pi gacchati tam ahạ̣ vātupādānam vadāmi vāto hissa Vaccha tasmim samaye upādānam hotī ti. yasmiñ ca pana bho Gotama samaye imañ ca kāyam nikkhipati satto ca añnataram kāyam anuppanno hoti. imassa pana bhavam Gotamo kim upādānasmim paññāpetī ti. yasmim kho Vaccha samaye imañ ca kāyam nikkhipati satto ca añnataram kāyam anuppanno hoti. tam aham tạ̣hupādānam vadāmi. tạ̣hā hissa Vaccha tasmịn samaye upādānam hotì tì.

46 SN IV p. 213, V pp. 319-20, MN III p. 245.

47 Collins (1998: 191).

48 MN III p. 245 (quoted from Collins (1998: 191)).

49 See this chapter, note 37.

50 See this chapter, note 23 .

51 See Cousins (1983: 97).

52 Schrader (1905: 167-8).

53 See this chapter, note 3.

54 SU I 13 (tr. Olivelle).

55 Olivelle (1996: 387).

56 In the later thought the term linga has the technical meaning of 'subtle form' (Olivelle 1996: 387).

57 BAU I 46 (tr. Olivelle).

58 Olivelle (1996: 296).

59 SU I 15-16.

60 SN IV p. 213, V pp. 319-20, MN III p. 245.

61 Vin I p. 196.

62 Lamotte (1988: 157).

63 Lamotte (1988: 161).

64 Lamotte (1988: 161-2). 
65 Tr. Norman (1992: 120): accī yathā vātavegena khitto Upasīvā ti Bhagavā attham paleti na upeti saṃkham evam mun̄ nāmakāyā vimutto attham paleti na upeti saṃham (Sn pp. 206-7).

66 Collins (1998: 218).

67 PED p. 350.

68 DN II p. 62, Pațis I p. 183.

69 Cul p. 181: nāmakāyā vimutto ti so muni pakatiyā pubb' eva rūpakayā vimutto tadañga samatikkamā vikkhambhanapahānena pahīno . . .

70 The commentary of the Cullanidesa also confirms this point (Sdp III p. 32).

71 MN III p. 245, SN II pp. 399-400.

72 See this chapter, notes $37,45$.

73 SU I 13 (tr. Olivelle): 'When a fire is contained within its womb (yoni), one cannot see its visible form and yet its essential character (linga) is not extinguished; one can grasp the fire once again from its womb by means of tinder.' See 'The image of a fire in the early Upanișads' in this chapter.

74 See this chapter, note 2.

75 The noun nibbāna is derived from the negative prefix nir plus the root $v \bar{a}$ (to blow).

76 MWD p. 122.

77 AN II p. 51.

78 Ñyānamoḷi (1976: 577 note 16). I discuss this matter in detail at the end of this chapter.

79 The stanza used in Sanskrit was Pradyotasyeva nirvānam vimokșas tasya cetasa iti. It was used by Vasubandhu in a debate on the ontological issue of nirvana against the Sarvāstivādins in the second chapter of the Abhidharmakośabhāsya (Akb-p p. 94, La Vallée Poussin 1923: 285). His opinion was later contested by Sañghabhadra in his Nyāyānusāraśästra (Na TD29 pp. 432c-433a). This stanza was also quoted in the Prasannapadā, the commentary on Mülamadhyamakakārikā (Mmd-p p. 525, Stcherbatsky 1968: 201). I discuss this ontological issue in 'Interpretation of Anuruddha's verse' in Chapter 5.

80 DN II p. 157, SN I p. 159, Th p. 84, Thī p. 116: nāhu assāsapassāso țitacittassa tādino, anejo santimārabbha cakkhumā parinibbuto. asallinena cittena vedanam ajjhavāsayi, pajjotasseva nibbānam vimokkho cetaso ahu.

81 AN I pp. 235-6, IV 3: pajjotass' eva nibbānam, vimokho hoti cetaso ti.

82 Th-a III p. 71: pajjotass' eva nibbānam, vimokkho cetaso ahū ti yathā telañca pațicca vațtiñca pațicca pajjalanto pajjoto padīpo tesam parikkhaye nibbāyati, nibbuto ca katthaci gantvā no tițthati, añnadatthu antaradhāyati, adassanam eva gacchati, evam kilesābhisaìkhäre nissāya pavattamāno khandhasantāno tesam parikkhaye nibbāyati, nibbuto ca katthaci gantvā na tițthati, aññadatthu antaradhāyati, adassanam eva gacchatī ti dasseti. tena vuttam nibbanti dhīrā yathāyam padīpo ti acci yathā vātavegena khittā 'ti ādi.

83 Ñyānamoli (1976: 319 note 72).

84 Khp 5, also in Sn 41.

85 Ñyāṇamoḷi (1960: 216).

86 See this chapter, note 65.

$87 \mathrm{Kv}$ pp. 225-7.

88 Dhs pp. 192-3, no. 1083-4, Dhātuk pp. 5-8.

89 Vibh pp. 72-3, Dhātuk p. 7, no. 58.

90 Vibh p. 89, Dhātuk p. 5 no. 58.

91 For the Sarvāstivādins, nirvana is not the one and only unconditioned but one of three unconditioned things. See 'The Chinese abhidharma works' in Chapter 3. 
$92 \mathrm{Pk}$ (TD26 723c, 766b).

93 Bareau (1955: 168).

94 See 'The image of a fire extinguished in Vacchagotta's question' in this chapter.

95 See 'Upādisesa within the context of nirvana' in Chapter 2.

96 See 'The Chinese abhidharma works' in Chapter 3.

97 Frauwallner (1995: 145).

98 La Vallée Poussin (1923: 81-2).

99 Akb-h p. 15, Sa-w p. 49: yathà ghațoparamo na ghațah, evam skandhoparamo na skandhah.

$100 \mathrm{Mv}$ (TD27 385b).

101 Lamotte (1988: 594-7).

102 Cousins (1983: 102-3). See also Collins (1998: 175-6).

103 Dhs p. 226 no. 1309.

104 Dhs pp. 192-3, no. 1083-4.

105 Dhātuk p. 5: asan்khatam khandhato thapetvā.

106 Vibh pp. 72-3.

107 Vibh p. 89.

108 Vibh pp. 72-3, p. 89.

109 The Chinese equivalent of this sutta was slightly different. The answer given here was 'The cessation of passion, the cessation of hatred, the cessation of delusion and the cessation of cankers (äsavas), that is called nirvana' (SA TD2 126b).

110 SN IV pp. 251-2.

111 See 'Upādisesa within the context of nirvana' in Chapter 2.

112 See this chapter, note 97.

$113 \mathrm{Kv}$ p. 226: atthi dvinnam nibbānānam uccanīcatā hīnapaṇītatā ukkaṃsāvakaṃso

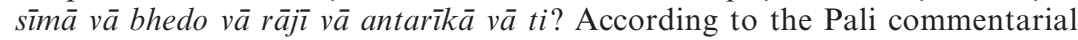
tradition, the opponents were the Mahimsāsakas and the Andhakas (Aung and Rhys Davids 1915: 136). Thus, both sects regard the two extinctions as nirvana, while only pațisankhanirodha (extinction through knowledge) is the equivalent of nirvana in the Sarvāstivāda abhidharma.

114 Bareau (1951: 31).

115 EOB p. 149.

116 Cousins (1983: 104).

$117 \mathrm{Kv}$ p. 330.

118 Dhs p. 144, Also see Vibh pp. 84-5.

119 yo ākāso ākāsañgatam agham aghagatạn vivaro vivaragatam asamphuțtham catūhi mahābhūtehi idan tam rūpam ākāsadhàtu (Dhs p. 144).

120 Vibh p. 84.

121 Akb-h p. 3.

122 Akb-h p. 18. This space element is not a real existent (dravya).

123 aghasāmantakarūpa meaning according to the Abhidharmakośabhāṣya (La Vallée Poussin 1923: 89), a type of matter next to (sämantaka) solid agglomerated matter (agha). It was quoted from the Mahāvibhāṣāsáāstra (Mv TD27 388b).

$124 \mathrm{Kv}$ pp. $330-1$.

$125 \mathrm{Kv}-\mathrm{a}$ p. 93.

$126 \mathrm{Kv}$ pp. 328-30.

127 Bareau (1951: 253), Cousins (1983: 105).

128 Mil p. 268.

129 Mil p. 388.

130 Masuda (1925: 28-9, 61), Bareau (1955: 67, 185).

$131 \mathrm{Mv}$ (TD27 161a). 
132 Bareau (1955: 285).

133 Bareau (1955: 167-80).

134 ye hi sarvam astīti vadanti, atītam anāgatam pratyutpannam ca, te sarvāstivādāh ye tu kị̣ cid asti, yat pratyutpannam adattaphalam cātītạ̣ karma, kị̣ cin nāsti, yad dattaphalam atītam anāgatam ceti vibhajya vadanti, tevibhajyavādinah. (Akbh p. 296, La Vallée Poussin 1923: 808). kim cit (ke cit in the text) in the first line is an emendation by Professor A. Sanderson in his Oxford MPhil class in Classical Indian Religion.

135 Bareau (1955: 168).

136 See 'The Chinese abhidharma works' in Chapter 3.

$137 \mathrm{Mv}$ (TD27 104b, 237b, 910c): 答前是廣説後是略説. 前是別説後是總説. 前是分 別説後是不分別説. 前是漸説後是頓説.

138 Akb-x (TD29 104b).

$139 \mathrm{Mv}$ (TD27 586c-587a).

140 Bareau (1955: 177).

$141 \mathrm{Mv}$ (TD27 116c).

$142 \mathrm{Mv}(\mathrm{TD} 27$ 479c).

$143 \mathrm{Mv}$ (TD27 198b).

$144 \mathrm{Mv}$ (TD27 161a).

$145 \mathrm{Mv}$ (TD27 161a): 答為止他宗顯正義故. 謂或有執. 擇滅非擇滅無常滅非實有 體. 如譬喻者為遮彼執顯三種滅皆有實體. 或復有執. 此三種滅皆是無為. 如分別 論者. 為遮彼執顯二滅是無為. 無常滅是有為. 故作斯論.

146 According to Louis de La Vallée Poussin (1923: 140 note 91), Vasubandhu recognises five kinds of extinction (nirodha): lakșananirodha, samāpattinirodha, upapattinirodha (=āsamjñika), pratisaṃkhyānirodha and apratisamkhyānirodha. Extinction as impermanence (anityatänirodha) here means extinction by virtue of the impermanence which is the characteristic of conditioned dharmas: i.e. the characteristic of ceasing (lakșananirodha).

147 Masuda (1925: 67), Lamotte (1936: 25-6).

148 Cox (1995: 37-41).

$149 \mathrm{Mv}$ (TD27 198b).

150 See 'The Chinese abhidharma works' in Chapter 3.

151 I discuss this matter in detail in 'Interpretation of Anuruddha's verse' in Chapter 5.

152 Akb-h p. 93: bhāvāntaratve 'pi yasya kleśasya prāptivicchedād yo nirodhah prāpyate sa tasyeti vyavadiśyate.

$153 \mathrm{Na}(\mathrm{TD} 29$ 432c-433a).

154 Stcherbatsky (1968: 201).

155 Vism p. 432 (tr. Ñyāṇamoḷi 1976: 580): anuppattinirodhasañkhātassa pana khayassa pariyāyena upanissatattā, yassa upanissayo hoti, tadupacārena khayo ti vuttam.

156 See 'Nirvana and space in the Pali abhidhamma tradition' in this chapter.

157 Vism p. 431 (tr. Ñyāṇamoḷi 1976: 579): vattamānānam pi abhāvo nibbānan ti ce, na, tesam abhāvāsambhavato, abhāve ca avattamānabhāvāpajjanato; vattamānakkhandhanissitamaggakkhane ca sopādisesanibbānadhātuppattiyā abhāvadosoto. tadā kilesānam avattamānattā na doso ti ce, na, ariyamaggassa niratthakabhāvāpajjanato. evam hi sati ariyamaggakkhaṇato pubbe pi kilesā na santī ti ariyamaggassa niratthakabhāvo āpajjati.

158 Ñyāṇamoḷi (1976: 577).

159 Vibh-a p. 51: vitandavād̄̄ pan' āha: pātịyekkạ̣ nibbānam nāma na atthi, kilesakkhayo va nibbänan ti. suttam āharā ti ca vutte "nibbānaṃ nibbānan ti āvuso Säriputta vuccati, katamạ̣ nu kho āvuso nibbānan ti? yo kho āvuso rāgakkhayo, 
dosakkhayo, mohakkhayo, idạ̣ vuccati nibbānan' ti etạ̣ Jambukhādaka-suttam āharitvā iminā suttena veditabbam pāțiyekkam nibbānam nāma na atthi, kilesakkhayo va nibbānan ti āha.

160 Vibh pp. 72-3, 89.

161 Vibh-a p. 51: yasmā pan' etam àgamma rāgādayo khīyanti.

162 Vibh-a p. 54: evam avijjā ca tanhā ca tam àgamma tamhi khīnam, tamhi bhaggam, na ca kiñci kadācī ti.

163 Vism p. 431 (tr. Ñyāṇamoli 1976: 577-8).

164 For this passage Nyānamoḷi (1976: 577-8 note 16) comments: “"On coming to that (tam ägamma)": on reaching that nibbana by making it the object' (Pm. 533). $\bar{A}$ gamma (ger. of ägacchati - to come) is commonly used as an adverb in the sense of 'owing to' (e.g. at M.i., 119). Here, however, it is taken literally by the commentaries and forms an essential part of the ontological proof of the positive existence of nibbana. The Sammohavinodani (commentary on the Ayatana Vibhanga Abhidhamma-bhäjaniya) refutes the suggestion of a disputant (Vitaṇuavādin) who asserts that nibbana is 'mere destruction (khayamatta)'. The arguments used are merely supplementary to those here, and so are not quoted. The conclusion of the argument is worth noting, however, because of the emphasis on the words 'tam āgamma'. It is this: 'It is on coming to nibbana that greed etc., are destroyed. It is the same nibbana that is called "destruction of greed, destruction of hate, destruction of delusion". These are just three terms for nibbana. When this was said, he asked: You say "On coming to (ägamma)"; from where have you got this "on coming to"? It is got from the Suttas. Quote the sutta. "Thus ignorance and craving, on coming to that, are destroyed in that, are abolished in that, nor does anything anywhere ... (evam avijja ca tanhā ca tam ägamma tamhi khīnam tamhi bhaggam na ca kiñci kadāci... .)." When this was said, the other was silent.' The quotation has not been traced.

165 Sn 206-7. See this chapter, note 65.

166 See 'Interpretation of Anuruddha's verse' in Chapter 5.

167 Akb-h p. 94.

168 See this chapter, note 77.

\section{NIRVANA IN NORTHERN BUDDHIST SCHOOLS}

1 See 'The Chinese abhidharma works' in Chapter 2.

2 Akb-d pp. 324-5, Lamotte (1988: 611).

3 Akb-h p. 92.

4 Akb-h pp. 92-4.

$5 \mathrm{Na}$ (TD29 pp. 431-3).

6 Mmd-p p. 525, Stcherbatsky (1968: 201).

7 Mv (TD27 167b): 謂契經説. 有二涅槃界. 一有餘依涅槃界. 二無餘依涅槃界. 契 經雖作是説而不廣辨. 云何有餘依涅槃界. 云何無餘依涅槃界. 彼是此論所依根 本. 彼所不分別者今皆應分別之.

8 Here ci-lun (此論) means the Jñannaprasthāna. The word ben-lun (本論) is used to designate the Mahāvibhāṣāśāstra (Mv TD27 168b).

9 EA (TD2 159a). See also 'The non-returner and the two nirvana elements' in Chapter 2.

10 Ip p. 38. See also 'Upādisesa within the context of nirvana' in Chapter 2.

11 See 'The Theravāda exegetical position on nirvana' in Chapter 4.

12 TD17 pp. 667-8.

13 See 'Sarvāstivāda interpretation in the Jñānaprasthāna' in Chapter 3.

$14 \mathrm{Jp}$ (TD26 923b). 
15 Life faculty is one of the twenty-two controlling faculties as well as one of fourteen dharmas not associated with the mind (cittaviprayuktasamskāra) in the Sarvāstivāda system. See Cox (1995: 125-31).

16 Homogeneous character of the group is one of fourteen dharmas not associated with the mind (cittaviprayuktasamska $\bar{r}$ ) and is said to determine the specific rebirth state of sentient beings. See Cox (1995: 107-12). According to the Abhidharmakośabhāṣya, homogeneous character of the group (nikāyasabhāga, 眾同分) and homogeneous character (sabhāgatā, 同分) were virtually the same (La Vallée Poussin 1923: 219). Cox translates the former as 'homogeneous character of the group' or 'the homogeneous collection of components', the latter as 'homogeneous character' (Cox 1995: 109).

$17 \mathrm{Mv}$ (TD27 167c): 此中壽命者. 謂命根. 問何故不説眾同分耶. 答是作論者意欲 爾故. 乃至廣説. 復次應説而不説者. 當知此義有餘. 復次以命根眾同分俱是牽引 業果. 命根一向是異熟故. 此中偏説.

18 Action that projects existence (äkșepakakarman) designates an action that will project one new existence. For the Sarvāstivāda-Vaibhāșikas, it projects life faculty (jānitendriya) and homogeneous character of the group (nikāyasabhāga) at the moment of conception, whereas for the Sautrāntikas it initiated the momentum or power ( $\bar{a} v e d h a$ ) into the series of aggregates to last for a certain lifetime. Later in the Yogācāra system, äkșepahetu is one of ten causes and is used when good or bad action eventually projects its results in one of the three worlds, the world of desire, the world of form and the world of the formlessness (DBT p. 326d).

19 It designates vitality (āyus) mentioned above.

20 Pk (TD26 694a), La Vallée Poussin (1923: 233).

21 See 'The Theravāda exegetical tradition' in Chapter 3.

22 La Vallée Poussin (1923: 233).

23 SN III p. 143.

24 MN I p. 295. See also Jaini (1959: 539).

25 See 'The Sarvāstivāda interpretation in the Jñänaprasthāna' in Chapter 3.

26 SN V p. 204.

27 Cox (1995: 125).

28 MA (TD2 462b), EA (TD2 628a). See Cox (1995: 122, 130).

29 See Table 3.1, p. 39.

30 Ds (TD26 499a).

31 See Table 3.1, p. 39.

$32 \mathrm{Pk}$ (TD26 694a).

$33 \mathrm{Mv}(\mathrm{TD} 27$ 657c).

$34 \mathrm{Mv}$ (TD27 732b).

$35 \mathrm{Mv}$ (TD27 731c).

36 Literally, it says 'it allows us to say we are possessed of controlling faculties'.

37 MN I p. 295. See also Jaini (1959a: 539).

38 La Vallée Poussin (1923: 154).

$39 \mathrm{Mv}$ (TD27 169a): 有餘依故者. 依有二種. 一煩惱依. 二生身依. 此阿羅漢雖無煩 惱依而有生身依. 復次依有二種. 一染污依. 二不染污依. 此阿羅漢雖無染污依而 有不染污依故.

$40 \mathrm{Cf}$. clinging (upadhi) in the context of 'without a remainder of clinging' (anupadhiśeșa) was glossed in Mv (TD27 169a): 'When saying "as there is no remainder of clinging", no [remainder of] clinging is of two kinds: no clinging as defilement (kleśopadhi) or no clinging as birth body (janmakāyopadhi). Alternatively, [no remainder of clinging is of two kinds:] no defiled (klista) clinging or no undefiled clinging.' 
41 Sap (TD26 415c), Ds (TD26 512c), Jp (TD26 921c), Mv (TD27 138a).

42 La Vallée Poussin (1923: 219-21). See also Cox (1995: 107-12).

43 Akb-h p. 258, La Vallée Poussin (1923: 677).

$44 \mathrm{Mv}$ (TD27 99a).

$45 \mathrm{Mv}$ (TD27 100a).

46 La Vallée Poussin (1923: 678).

$47 \mathrm{Mv}$ (TD27 169a). See this chapter, note 18.

48 It p. 38.

49 Mv (TD27 167c-168a): 身根覺未斷名有餘依涅槃.

$50 \mathrm{Mv}$ (TD27 167c): 此身根覺相續未斷諸結永盡. 名有餘依涅槃界.

$51 \mathrm{Mv}$ (TD27 168a): 或身根覺相續已斷諸結永盡. 名無餘依涅槃界.

52 It p. 38.

$53 \mathrm{Mv}$ (TD27 168b): 頗有阿羅漢不住有餘依涅槃界. 及無餘依涅槃界耶. 答理雖無 有而依此中所説亦有.

$54 \mathrm{Mv}$ (TD27 168b): 生無色界阿羅漢. 無色身故非住有餘依涅槃界. 有心轉故. 非 住無餘依涅槃界. 生有色界阿羅漢入滅盡定. 已無心轉故非住有餘依涅槃界. 有 色身故非住無餘依涅槃界. 生欲界不具根阿羅漢. 不具五根故非住有餘依涅槃 界. 有色身故非住無餘依涅槃界.

$55 \mathrm{Jp}$ (TD26 921c), Mv (TD27 137a).

56 Later in the text, it says 'The author of the treatise (the Mahāvibhāsāaśāstra) gave this opinion for the sake of all disciples to understand [the two nirvana theory] easily.'

$57 \mathrm{Mv}$ (TD27 168b): 有説. 此文應作是説. 云何有餘依涅槃界. 答若阿羅漢壽命猶 存諸結永盡得獲觸證. 云何無餘依涅槃界. 答即阿羅漢壽命已滅諸結永盡.

$58 \mathrm{Mv}$ (TD27 168a): 答依現在得説得等言. 現在得斷是故不説. 復次依補特伽羅故 施設得獲觸證. 此中無有補特伽羅唯惟有法性. 是故不説.

59 Mil p. 27.

60 Lamotte (1988: 606).

$61 \mathrm{Mv}(\mathrm{TD} 27$ 169b).

$62 \mathrm{Mv}$ (TD27 168a). See this chapter, note 58.

$63 \mathrm{Mv}$ (TD27 168a). See this chapter, note 58.

64 Vs-c (TD43 274a). See Masuda (1925: 67), La Vallée Poussin (1928: 48), Lamotte (1936: 19).

65 Cox (1995: 40-1).

66 Cox (1995: 37-9). See also 'The Theravāda exegetical position on nirvana' in Chapter 4.

67 Cox (1995: 40-1).

68 Cox (1995: 40-1).

69 Jp (TD26 p. 923b).

$70 \mathrm{Mv}$ (TD27 pp. 167b-168b).

71 See this chapter, note 14.

72 La Vallée Poussin (1923: 219). See this chapter note 16.

73 Sap (TD26 415c), Ds (TD26 512c), Jp (TD26 921c), Mv (TD27 138a).

74 Cox (1995: 109).

75 La Vallée Poussin (1923: 220-1).

76 Cox (1995: 109): '(1) homogeneous character is not different from the nature of an ordinary person; (2) since homogeneous character has no form and cannot be directly perceived, its activity cannot be known; (3) the homogeneous character of insentient objects should also be admitted; (4) since another homogeneous character is required to account for the similarity among all varieties of homogeneous character, infinite regress would result; and (5) homogeneous character is nothing other than the Vaiśeșika categories of generality (sāmānya) or of particular generalities (sāmānyaviśeșa).' 
77 Akb-h pp. 67-8.

78 According to Jayatilleke (1980: 57), four criteria mentioned in the Taittiriya Áranyaka were 'pratyakșa (perception), anumāna (inference), smṛti (scripture) and aitihya (tradition)'.

79 Jayatilleke (1980: 58).

80 Sa-w p. 158.

81 Akb-h p. 93, La Vallée Poussin (1923: 284).

82 Akb-h p. 461, La Vallée Poussin (1923: 1313).

83 Akb-h p. 67.

84 Akb-h p. 93, La Vallée Poussin (1923: 283).

85 nahi nāstīti brümo natu dravyāntaram, Akb-h p. 94.

86 traidhātukena karmanā nikāyasabhāgasya sthitikālāvedhah, Akb-h p. 94.

87 See 'The development of the two nirvana theory in the Mahāvibhasṣasśästra' in this chapter.

88 Akb-h p. 258. See also La Vallée Poussin (1923: 677).

89 tathābhūtās saṃskārā rūp'ādiskandhasvabhāvā, Sa-w p. 168.

90 La Vallée Poussin (1923: 234-5).

91 Jaini (1959: 541-2).

92 Masuda (1925: 66).

$93 \mathrm{Jp}$ (TD26 p. 923b).

$94 \mathrm{Mv}$ (TD27 p. 167b).

95 See 'Upādisesa within the context of nirvana' in Chapter 2.

96 See Cox (1995: 82-92).

97 Akb-d pp. 324-5; Lamotte (1988: 611).

98 na hi tasya rūpavedanādivat svabhāva upalabhyate no cāpi cakșurādivat karma, Akb-p p. 93.

99 utpannānuśayajanmanirodhe pratisaṃkhābalenānyasyānutpādah pratisaṃkhyānirodhah, Akb-h p. 92.

100 Sa-w p. 219.

101 See 'The Chinese abhidharma works' in Chapter 3.

102 See 'The Theravāda exegetical tradition' in Chapter 3.

103 See 'The two nirvana theory in the early canon' in Chapter 2.

104 Th-a I p. 46, Dhp-a II p. 163.

$105 \mathrm{Jp}$ (TD26 923b), Mv (TD27 167b).

106 Jaini (1959b: 239).

107 Akb-h p. 278, Jaini (1959b: 242).

108 See 'The Chinese abhidharma works' in Chapter 3.

109 See also Cox (1995: 93-4).

110 One reason why the Sarvāstivādins insist on the existence of all dharmas in the three time periods is causal efficacy of past action (karma). See La Vallée Poussin (1923: 818), Masuda (1925: 39), Lamotte (1988: 602).

111 See Lamotte (1988: 606-7), La Vallée Poussin (1923: 206-19).

112 See 'The Chinese abhidharma works' in Chapter 3.

113 ko'ayam bījabhāvo nāma. ātmabhāvasya kleśajākleśstpādanaśaktih yathānubhavajñānajā smrtyutpādanaśaktir yathācānkurādīnām śāliphalajā śäliphalotpādanaśaktiriti, Akb-h p. 278. See also La Vallée Poussin (1923: 770).

114 Body (ātmabhāva) was glossed as support (äsraya) in the Sphuțārthā Abhidharmakośavyākhyā (Sa-w p. 444).

115 tena ca kleśadvayenāsyām santatau büjabhāva āhito’nāgatasyotpattaye. tasya prahānāt tad api prahīnam bhavati, yathā vipākakșayāt karma kșinạ̣ bhavati, Akb-h pp. 92-3.

116 Lamotte (1988: 607).

117 La Vallée Poussin (1923: 770, 1339). 
118 La Vallée Poussin (1923: 1352-4).

119 See also Jaini (1959b: 243).

120 kị̣ punar idạ̣ bījam nāma. yannāmarūpam phalotpattau samarthạ̣ sākșāt pāramparyeña vā santatiparināmaviśeșāt. ko'yam parināmo nāma. santater anyathātvam. kā ceyam santatiḥ. hetuphalabhūtās traiyadhvikāh saṃskārāh. Akbh p. 64. See also La Vallée Poussin (1923: 211), Jaini (1959b: 243).

121 Vasubandhu (Akb-h p. 92) used the word ăhita derived from $\bar{a} \sqrt{d h} \bar{a}$ (to place on).

122 La Vallée Poussin (1923: 1353), Cox (1995: 104 note 47).

$123 k \bar{a}$ punah samtatih kah parināmah ko viśeșah. yah karmapūrva uttarottaracittapravasah sā samtatis tasyā anyathotpattih parināmah. sa punaryo'ntaram phalotpādanasamarthah so'ntaparināmaviśiștatvāt parịnāmaviśeșah, Akb-h p. 477.

124 La Vallée Poussin (1923: 1352-3).

125 yathā lākṣārasarañjitāt mātulungapuṣpāt saṃtatiparināmaviśeșajah phale raktah keśara upajāyate na ca tasmāt punar anyah evam karmajād vipākāt na punar vipākāntaram iti, Akb-h p. 478.

126 sarvākāram kāraṇam ekasya mayūracandrakasyāpi nāsarvajñair jñeyam. sarvajñabalam hi taj-jñānam, Akb-h p. 474.

127 See La Vallée Poussin (1923: 230-2).

128 Lamotte (1988: 608).

129 Lamotte (1936: 103-11). See also Jaini (1959b: 244).

130 See this chapter, note 99.

131 Akb-h p. 92.

132 SA (TD2 184a22-24). Cf. SN V 236 (according to Pasadika 1986): 'Oh monks, five faculties if cultivated and developed conduce to the abandonment of bonds' ( pañcimāni bhikkhave indriyāni bhāvitāni bahul̄̄katāni saṃyojanānam pahānāya samvattanti). Five faculties are the faculty of faith, of energy, of mindfulness, of concentration, and of wisdom.

133 Akb-h p. 92.

134 See Akb-h p. 63, La Vallée Poussin (1923: 209-10), and Cox (1995: 94).

135 pratipakșalābhena kleśapunarbhavotpādātyantaviruddhāśrayalābhāt prāptam nirvānam, Akb-h p. 93.

136 traidhätukena karmaṇā nikāyasabhāgasya sthitikālāvedhah, Akb-h p. 94.

137 tathābhūtās samskārà̄ rūp'ādiskandhasvabhāvā, Sa-w p. 168.

138 La Vallée Poussin (1923: 234).

139 See 'The Pārāyana stanza in the Suttanipāta' in Chapter 4.

140 Vibh-a p. 41.

$141 \mathrm{Na}$ (TD29 433a).

142 DN II 157, SN I 159, Th 84, Thī 116.

143 Akb-p p. 94, La Vallée Poussin (1923: 285).

$144 \mathrm{Na}$ (TD29 432c-433a).

145 Mmd-p p. 525, Stcherbatsky (1968: 201).

146 pradyotasyeva nirvānam vimokșas tasya cetasah, Akb-h p. 94.

147 yathā pradyotasya nirvānam abhāva evam bhagavato 'pi cetaso vimokșa, (Akb-p p. 94).

148 amușya ca vastuno 'yam nirodhah iti șașthīvyavasthā katham prakalpyate. na hi tasya tena sārdham kaś cit saṃbandhah, hetuphalādibhāvāsambhavāt. pratiședhamātram tu yujyate amuṣyàbhāva iti. bhāvāntaratve 'pi yasya kleśasya prāptivicchedād yo nirodhah präpyate sa tasyeti vyavadiśyate. tasya tarhi prāptiniyame ko hetuh? dṛștadharmanirvānaprāptau bhikșuh ity uktạn sūtre. tatra katham abhāvasya prāptih syāt? pratipakșalābhena kleśapunarbhavotpādātyantaviruddhāśrayalābhāt prāptam nirvānam ity ucyate, Akb-h p. 93. 
149 SA (TD2 57c8), SN IV 109.

150 These two steps are compared to throwing out a thief and closing the door or the catching an insect in a jar and plugging the jar's mouth, Mv (TD27 333c334a), La Vallée Poussin (1923: 949-50). See also 'The Chinese abhidharma works' in Chapter 3.

151 See 'Nirvana from the Sautrāntika ontological perspective' in this chapter.

152 See Akb-h p. 63, La Vallée Poussin (1923: 209-10) and Cox (1995: 94).

153 kim evam neșyate nāsmin prādurbhāva ity ato 'prādurbhāva iti?? asamarthām etām saptamìm paśyāmah. kim uktam bhavati? nāsmin prādurbhavatīti yadi satīty abhisambadhyate, nityam evāprädurbhāvaprasañgah nirvānasya nityatvāt. atha prāpta ity abhisambadhyate yata eva tatprāptih parikalpyate tasmim sati mārge prāpte vā duhkhasyeșyatām aprādurbhāvah, Akb-h p. 94.

154 tasmim sati mārge prāpte vā, Sa-w p. 221. Akb-h (p. 94) reads differently: when it [noble path] is at hand or attained' (tasmim eva sammukhībhüte prāpte vā).

155 See 'Influence of the Buddhist theory of momentariness' in Chapter 4.

156 Vism p. 432: nirvana is 'cessation consisting in non-arising'.

157 Akb-h p. 92: the extinction through knowledge is, when latent defilements (anuśaya) and life (janman) that have already been produced are extinguished, non-arising of further such by the power of knowledge (pratisamkhyā).

158 Mmd-p p. 525, Stcherbatsky (1968: 201).

$159 \mathrm{Na}$ (TD29 432c-433a): 對法諸師. 已通此説. 謂言苦滅. 義有二途. 一離苦外無別 實體. 二離苦外有別實體. 佛觀所化意樂不同. 故説如斯二種滅義. 謂或有處説無 別體. 如向所引二種契經. 或復有處説有別體. 如契經説. 定有無生. 又契經言. 有 處有離. 復有經説我觀實有無為句義. 所謂涅槃. 復有經言. 由五取藴滅故言滅. 此類定繁. 故我所宗. 不違聖教.

160 Anuruddha's stanza and one sūtra in the Samyukta-āgama (TD2 88a) quoted by Vasubandhu (Akb-x p. 94) to support his view: nirvana is mere nonexistence: 'That which is entire abandonment, relinquishment, coming to an end, exhaustion, detachment, cessation, tranquillization, disappearance of [even] the smallest suffering, and non-connection, non-arising, non-appearance of other suffering, that is lovely, that is excellent - that is to say, abandonment of all conditions, perishing of desire, detachment, cessation, nirvana.' Cf. AN I 100, V 421, SN I 136.

161 Ud pp. 80-1. For these suttas, see Collins (1998: 164-75).

$162 \mathrm{Akb}-\mathrm{x}$ (TD29 35a): 如燈涅槃唯燈焰謝無別有物. 如是世尊心得解脱. 唯諸蘊滅.

$163 \mathrm{Na}$ (TD29 433a): 又經所説燈焰涅槃. 離燈別有無常相故. 此之所喻. 於義何違 或燈涅槃. 雖無別體. 而非非有. 諸行皆是無常性故. 其體非無. 依此為言. 亦無 有過.

164 La Vallée Poussin (1923: 238).

165 La Vallée Poussin (1923: 239).

166 La Vallée Poussin (1923: 240), Mv (TD27 200c).

167 See 'The Chinese abhidharma works' in Chapter 3.

168 See also Cox (1995: 93-4).

169 SN IV pp. 399-400, MN III 245.

170 SU I 13.

171 'An expiring flame does not really go out, but returns into the primitive, pure, invisible state of fire it had before its appearance as visible fire' (Schrader 1905: 167).

172 See 'The image of a fire extinguished in Vacchagotta's question' in Chapter 4.

173 Akb-x (TD29 35a). See this chapter, note 147.

174 SN IV pp. 399-400, MN III 245.

175 See 'The Pārāyana stanza in the Suttanipāta' in Chapter 4.

176 Th-a III 71. 
177 See 'Influence of the Buddhist theory of momentariness' in Chapter 4.

178 yam pan' etam dhammāyatana-niddese tattha katamā asankhatadhātu? rāgakkhayo, dosakkhayo, mohakkhayo ti vuttam, tatrāyam attho: asankhatadhātū ti asankhatasabhāvam nibbānam. yasmā pan' etam āgamma rāgādayo khīyanti, tasmā rāgakkhayo, dosakkhayo, mohakkhayo ti vuttam. ayam ettha ācariyānam samānatthakathā, Vibh-a p. 51.

179 Vibh-a 54: evam avijjā ca tanhā ca tam àgamma tamhi khīnam, tamhi bhaggam, na ca kiñci kadācì ti.

180 DN II 157, SN I 159, Th 84, Thī 116.

$181 \mathrm{Na}$ (TD29 433a): 此經唯就入無餘依般涅槃時.

182 See 'Nirvana and space in the Pali abhidhamma tradition' in Chapter 4.

183 See 'The Chinese abhidharma works' in Chapter 3.

\section{CONCLUSION}

1 Gombrich (1996: 65).

2 DN II p. 314, MN I pp. 62, 63, 481, SN V pp. 129, 181, 236, 313, AN III pp. 82, 143, AN V p. 108, It pp. 39, 40, 41, Sn p. 64.

3 EA (TD2 579a).

4 MN II p. 146, III p. 247, SN V p. 347.

5 BAU VI 2 15, CHU IV 15 5, VIII 15.

$6 \mathrm{Mv}$ (TD27 169a).

7 SU I 13.

8 MN I p. 487, SN IV pp. 399-400.

9 SU I 13.

10 MN I p. 487.

$11 \mathrm{Na}$ (TD29 433a).

$12 \mathrm{Mv}$ (TD27 168a).

13 Vism p. 242, Spk I p. 196, Dhp-a III p. 424, It-a I p. 164, Vibh-a p. 314.

14 Vibh-a p. 51.

15 Vibh-a p. 61, Vism p. 431.

$16 \mathrm{Na}$ (TD29 433a).

$17 \mathrm{Mv}$ (TD27 147b).

18 Vism p. 432.

19 Akb-h p. 93.

20 Akb-h p. 92.

21 Akb-d pp. 324-5, Lamotte (1988: 611).

$22 \mathrm{Jp}$ (TD26 923b).

$23 \mathrm{Mv}$ (TD27 168a).

24 Lamotte (1973: 8).

25 La Vallée Poussin (1928: 670-1).

\section{SELECTED SOURCES FOR THE NIRVANA CONCEPT AND THE TWO NIRVANA THEORY}

1 Vibh-a pp. 51-4.

2 'Mental-data base', according to Ñyāṇamoḷi (1992: 61).

3 Vibh pp. 72-3.

4 'On coming to' also appears in the Visuddhimagga: 'But because craving fades away and ceases on coming to that, it is therefore called 'fading away' and 'cessation', Vism p. 431 (tr. Nyānamoli 1976: 577-8).

5 The Theravādins of the Mahāvihāra. 
6 SN IV 251-2.

7 The Chinese equivalent (SA: TD2 126b) of the Nibbānasutta answers differently: 'The cessation of passion, the cessation of hatred, the cessation of delusion and the cessation of cankers (äsavas)'.

8 According to Nyānamoli (1992: 61), 'But how? Is the meaning according to this sutta [literally] so?'

9 According to the Mülatika, 'this means that the meaning is explicit (nìto attho) in just the words of the sutta' (Ñyānamoḷi 1992: 66, note added by L. S. Cousins).

10 SN IV p. 252, SA (TD2 126b-c).

11 lañca BUCD, lañcha PTS.

12 The name of the sutta is not mentioned here.

13 Here the locative case was used to explain nirvana. A similar position appeared in the Abhidharmakośabhāṣya as a position of the Sarvāstivāda-Vaibhāṣikas insisting that nirvana is non-appearance and exists separately from mere cessation: 'because it does not appear in that, it is non-appearance', Akb-h p. 94.

14 See Chapter 4, note 164.

15 MV (TD27 167b-168b, TK 32 19-25). This translation is helped tremendously by Louis de La Vallée Poussin's French translation (La Vallée Poussin 1930: 24-8).

$16 \mathrm{Jp}$ (TD26 923b).

17 Here ci-lun (此論) means the Jñannaprasthāna. The word ben-lun (本論) is used to designate the Mahāvibhāsāāāstra.

$18 \mathrm{Jp}$ (TD26 923b). In the Mahāvibhāṣāśāstra, extinction through knowledge was further interpreted as: That is to say, it is the extinction of dharmas which is also attaining disjunction (visamyoga), the acquisition of disjunction (visamyogaprāpti). That is why it is called extinction through knowledge. In the Abhidharmakośabhassya, extinction through knowledge is defined as disjunction from impure dharmas (yah sāsravair dharmair visamyogah sa pratisaṃkhyānirodhah, Akb-d p. 4, Akb-p p. 4).

For the Sarvāstivāda-Vaibhāșikas, all dharmas exist as real existents in the three time periods. Thus, extinction could not mean that a certain impure dharma is actually destroyed. In this system, attaining a certain impure dharma does not mean that one, as a subject, possesses that impure dharma, as a object, but means that there is the arising of the acquisition (präpti) of that dharma in one's series (samtāna). Once there occurs the acquisition of the dharma, it renews its existence and continues its activity within the series until this acquisition is eliminated from the series. Since it is impossible to destroy this impure dharma, the elimination is referred to as a 'separation' from the series. That is to say, the acquisition of the defilement is negated, or technically 'disjoined' (visamyoga), through the power of knowledge which terminates the junction between that impure dharmas and the series of aggregates. 'Attaining the acquisition of disjunction (visamyogaprāpti)' mentioned in the interpretation in the Mahāvibhāṣâśăstra is regarded as the final step of this process. By reason of separating a certain dharma from one's series, there is the arising of 'the acquisition of disjunction' from the dharma within the series and it serves as antidote (pratipakșa) through which the junction between that dharma and one's series is forever prevented. The respective activities of these two steps are compared to that of throwing out a thief and closing the door or catching an insect in a jar and plugging the jar's mouth (Cox 1995: 89-92).

19 For the Sarvāstivādins, each dharma is unique as it is classified in terms of its intrinsic nature (svabhāva). Dharmas are classified under the five categories called pañcavastuka, and enumerated as seventy-five later in the Abhidharmakośabhāsya. Extinction through knowledge is one of three dharmas belonging to the 
unconditioned category. Thus, they seem to have had some difficulties in explaining how a unique dharma called extinction through knowledge could be of two kinds, nirvana with and without a remainder of clinging. In fact, the similar problem occurred when Buddhaghosa explained the two nirvana theory in the Visuddhimagga (Vism p. 432). Since nirvana is the one and only unconditioned thing in the Theravāda system, he had to make an excuse first, saying 'The aim of the Buddhas, etc. [i.e. nirvana] is one and of no distinction' before explaining the two nirvana theory.

$20 \mathrm{Jp}$ (TD26 923b).

21 The life faculty is one of the twenty-two controlling faculties as well as one of fourteen dharmas not associated with the mind (viprayuktasamskāra) in the Sarvāstivāda system. See Cox (1995: 125-31).

22 See Chapter 5, note 16.

23 See Chapter 5, note 18.

24 It designates vitality (âyus) mentioned above.

25 It designates mind (citta) in the mental series (cittasamtāna) mentioned above.

26 In the Sarvāstivāda system, there are four characteristics: arising, duration, decay, and ceasing. See Cox (1995: 133-58).

27 Later in this text, the author mentioned three things: the material body, the five faculties and the mental series.

28 It refers to homogeneous character of the group (nikāyasabhāga). When the Sarvāstivādins said 'one [action] projects one birth' (ekạ̣ janmākșipatyekam) in the Abhidharmakośabhāṣya (Akb-h p. 258, La Vallée Poussin 1923: 677), 'birth' was glossed as homogeneous character of the group (nikāyasabhāga).

29 Jp (TD26 923b).

30 That is to say, the last mind of an arahant. In the canon, the last step towards the final nirvana was the cessation of the mind: 'like the blowing out of a lamp, his mind becomes liberated' (AN I p. 236, AN IV p. 3, Th p. 81, DN II p. 157, SN I p. 159, Thī p. 116, Sn p. 41). Mental series (cittasamtäna) was used in the case of nirvana with a remainder of clinging.

31 By 'wind' we could assume vital force or biological energy.

32 Mind and mental states have faculties as their support.

33 The life faculty and homogeneous character of the group.

34 That is to say, the aggregates that are conventionally designated as a person ( pudgala) have been disintegrated, yet all dharmas that constitute the aggregates continue to exist since they exist as real existents in the three time periods.

35 This question raises a problem regarding the interpretation of the Jñanaprasthanna and suggests an opinion made by the author of the Mahāvibhāsāśästra.

36 The author of the Mahāvibhāṣâsástra suggests that it should be vitality (āyus) and not anything else through which we can distinguish nirvana with a remainder of clinging from nirvana without a remainder of clinging.

37 Here ben-lun (本論) is used to designate the Mahāvibhāsāásāstra. The word ci-lun (此論) is used to designate the Jñannaprasthāna.

38 This question establishes the difference between disjunction and two nirvana elements. Although disjunction from impure dharmas is possible for all people, it cannot be called nirvana with or without a remainder of clinging. It is only possible for aśaikșa, an arahant, in a certain moment: the first at a moment of enlightenment and the second at the moment of final death.

39 Akb-d pp. 322-7, Akb-p pp. 92-4, Akb-h pp. 92-4, Akb-pm (TD29 192a-c) and Akb-x (TD29 34a-35a). Although we have Poussin's translation (1988: 282-6), it does not exactly agree with the Sanskrit text because it was translated mainly from Xuan-zang's Chinese text. There also is Sakurabe's Japanese translation 
(1969: 378-82), which was made directly from the Sanskrit version. I have consulted both translations.

40 SA (TD2 184a22-4). Cf. SN V 236 (according to Pasadika 1986): 'O monks, five faculties if cultivated and developed conduce to the abandonment of bonds' ( pañcimāni bhikkhave indriyāni bhāvitāni bahulīkatāni samyojanānam pahānāya samvattanti). The five faculties are faith, energy, mindfulness, concentration and wisdom.

41 The Sautrāntika's position on extinction through knowledge, or nirvana, was basically non-arising of further defilements and life: 'It is said that nirvana is attained through acquiring the basis (äsraya) which prevents completely the arising of defilement (kleśa) and rebirth (punarbhava), by acquiring an antidote (pratipakșa)', ( pratipakșalābhena kleśapunarbhavopādātyantaviruddhāśrayalābhāt prātam nirvānam, Akb-h p. 93). Thus it could only be of the future and not of the past and present.

42 The same as Paramārtha's (Akb-pm (TD29 192a)). Xuan-zang, however, gives a slightly different reading: 'It does not necessarily conflict. Although there is that statement of the sütra, its meaning is not contradicted' (Akb-x (TD29 p. 34b)).

43 According to Yaśomitra (Sa-w p. 219, Sa-d p. 323), 'their objects' are past and present sufferings: 'through the abandonment of the defiling passions for their objects which are past and present sufferings' (atītapratyutpannaduhkh 'ālambanakleśaprahānād). Thus, in a way the physically perceptible and the rest are abandoned by eliminating desire and passion for them, and in that way past and present sufferings are abandoned by eliminating defiling passions for them.

44 SA (TD2 19c26), SN III 27.

45 In the Tainhasutta (AN II pp. 211-12), the speculations of craving (altogether thirty-six in number) are classified into two categories: the eighteen speculations of craving concerning the inner self and the eighteen speculations of craving concerning what is external to self.

46 Literally, 'the state of being seed'.

47 'And certainly there is no profit in making an effort at ceasing that which has already ceased in the past', according to Sa-w and Sa-d.

48 SA (TD2 225c27), AN III p. 34.

49 The Theravādins could have similar position. See Collins (1998: 181-2).

50 Vasubandhu applied a similar logic to deny the existence of homogeneous character (sabhāgatā), saying it is only the non-difference of birth (jātyabheda), Akb-h p. 67. That is to say, out of something cannot be a separate existent.

51 Akb-h pp. 298-303, La Vallée Poussin (1923: 812-20).

52 The same argument is applied to deny that pudgala, or attman, is a real existent (La Vallée Poussin 1923: 1314). 'In fact, unconditioned things are not known through direct perception (pratyakșa), as is the case for physical matter, sensation, etc.; and they are not known through inference (anumāna), by reason of their activity, as is the case for the sense organs', according to La Vallée Poussin (1923: 284). Neither direct perception nor inference is mentioned in any of the Sanskrit or Chinese versions, including Xuan-zang. Louis de La Vallée Poussin may have put those in because they are mentioned in Yaśomitra (Sa-d p. 325, Saw p. 221). We could also see this logic in the denial of homogeneous character (sabhāgatā) in the Abhidharmakośabhāşya (Akb-h pp. 67-8). Both direct perception (pratyakșa) and inference (anumāna) are mentioned in the Sphuțārtha Abhidharmakośavyākhyā (Sa-w p. 158).

53 While, for the Vaibhāșikas, the cessation or nirvana is one thing and suffering is another thing, cessation for the Sautrāntikas is just absence of suffering, i.e. nirvana is not a separate existent. 
54 The defilement is a genitive related to the cessation.

55 SA (TD2 57c8), SN IV p. 109.

56 Once anuśaya, the state of being seed, was destroyed by the power of intuition (darśana) and the noble path (mārga), name and form (nāmarūpa) which is the support (äśraya) for the anuśaya became special (viśeșa); that is to say, from a normal state of being with a power to produce a defilement to a special state of being without a power to produce a defilement, Akb-h p. 63, La Vallée Poussin (1923: 209-10) and Cox (1995: 94).

57 SA (TD2 88a9). Cf. AN I p. 100, V p. 421, SN I p. 136.

58 tasmim sati mārge prāpte vāa, Sa-w p. 221. Akb-h p. 94 reads differently: .when it[, noble path,] is at hand or attained' (tasmim eva sammukhībhüte prāpte vā). The Chinese translation done by Xuan-zang (Akb-x TD29 35a) support the reading of Sa-w.

59 SA (TD2 414a10), SA (TD2 210a20), DN II p. 157, SN I p. 159, Th p. 84.

60 The Chinese translation made by Xuan-zang (Akb-x TD29 35a2) reads differently: 'As the blowing out of a lamp could only be regarded as the extinction of a flame without any separate existent (dravyntara), the liberation attained by the mind of the blessed one could only be the extinction of all aggregates without any [separate existent]'; but the Paramartha's translation (Akb-pm TD29 p. 192c) confirms the Sanskrit reading. Although such scholars as F. Otto Schrader and Peter Harvey have insisted that 'the blowing out of a lamp' does not mean absolute non-existence, Vasubandhu's position on this simile is clearly against their opinions (Schrader 1905: 165-9; Harvey 1990: 66-7).

$61 \mathrm{Na}$ (TD 29 432c22-433a10/TK 17 20-1).

62 Anuruddha's stanza and one sūtra in the Samyukta-āgama (TD2 88a) quoted by Vasubandhu (Akb-x p. 94) to support his view: nirvana is mere non-existence: 'That which is entire abandonment, relinquishment, coming to an end, exhaustion, detachment, cessation, tranquillization, disappearance of [even] the smallest suffering, and non-connection, non-arising, non-appearance of other suffering, that is lovely, that is excellent - that is to say, abandonment of all conditions, perishing of desire, detachment, cessation, nirvana.' Cf. AN I p. 100, V p. 421, SN I p. 136.

63 Both suttas seems to be those in the Udanna Ud pp. 80-1) in the Pali Khuddakanikāya that were quoted by modern scholars to insist that nirvana cannot be mere non-existence. For these suttas, see Collins (1998: 164-75).

64 In this argument, Sangabhadra's position on a fire extinguished is very close to the so-called common Indian suggested by F. Otto Schrader (Schrader 1905: 167): 'an expiring flame does not really go out, but returns into the primitive, pure, invisible state of fire it had before its appearance as visible fire'. This view could have been originated from the essential character (linga) in the Śvetâśvatara Upānișad: 'When a fire is contained within its womb (yoni), one cannot see its visible form and yet its essential character (linga) is not extinguished; one can grasp the fire once again from its womb by means of tinder. In just the same way, one can grasp both within the body by means of the syllable OM' (SU I 13, tr. Olivelle). What is the difference between intrinsic nature (svabhāva) and essential character (linga) in the image of a fire extinguished?

65 A similar position can be found in the Theravāda tradition. They explain nirvana existing separately (pātiyekka) as different from the mere cessation of passion, hatred and delusion. The Sammohavinodani, the commentary on the Vibhainga, explains it as follows: 'But because passion etc. cease on coming to this [nirvana], it is said that it is the cessation of passion, the cessation of hatred, and the cessation of delusion' (Vibh-a p. 51). 


\section{BIBLIOGRAPHY}

\section{PRIMARY SOURCES}

Abhidhammatthasañgaha [Abhidh-s] and Abhidhammavibhāvinī-T̄̄kā, ed. H. Saddhātissa, PTS, Oxford, 1989.

Abhidharmakośa and bhāṣya of Acharya Vasubandhu [Akb-d] with Sphuțārthā Commentary of Ācārya Yaśomitra [Sa-d], ed. Swami Dwarikadas Shastri, Varanasi, 1987.

Abhidharmakośabhāṣya of Vasubandhu, Chapter I dhātunirdeśa [Akb-e], ed. Yasunori Ejima, Tokyo, 1989.

Abhidharmakośabhāṣya [Akb-h], ed. P. Pradhan, revised by A. Halder, Patna, 1975. Abhidharmakośabhāṣya [Akb-p], ed. P. Pradhan, Patna, 1967.

Abhidharmakośabhāṣya [Akb-pm], TD 29 (1559), tr. Paramārtha.

Abhidharmakośabhāşya [Akb-x], TD 29 (1558), tr. Xuan-zang.

Añguttara-nikāya [AN], ed. R. Morris, E. Hardy, PTS, London, 1885-1900.

Atthasālin̄̄ (Dhammasañgaṇī commentary) [As], ed. E. Muller, PTS, London, 1979.

Commentary of the Vijñāptimātrasiddhiśāstra [Vs-c], TD 43.

Cullaniddesa [Cul], ed. W. Stede, PTS, Oxford, 1988.

Dhammapada [Dhp], ed. O. von Hinÿber and K. R. Norman, PTS, Oxford, 1994-5.

Dhammapada-atthakathā [Dhp-a], ed. H. C. Norman, PTS, Oxford, 1970-93.

Dhammasangan̄i [Dhs], ed. E. Muller, PTS, London, 1885.

Dharmaskandha [Ds], TD 26 (1537).

Dhātukathā with commentary [Dhātuk], ed. E. R. Gooneratne, PTS, Oxford, 1987.

Dhätukāya [Dk], TD26 (1540).

Dīgha-nikāya [DN], ed. T. W. Rhys Davids, J. E. Carpenter and W. Stede, PTS, London, 1890-1911.

Dìrgha-āgama [DA], TD1 (1).

Ekottara-āgama [EA], TD2 (125).

Itivuttaka [It], ed. E. Windisch, PTS, London, 1975.

Itivuttaka-atthakathā [It-a], ed. M. M. Bose, PTS, London, 1977.

Jñānaprasthāna [Jp], TD 26 (1544).

Kathāvatthu [Kv] I-II, ed. A. C. Taylor, PTS, London, 1894-7.

Kathāvatthu-ațthakathā [Kv-a], ed. N.A. Jayawickrama, PTS, London, 1979.

Khuddakapātha [Khp], together with its commentary Paramatthajotikā (Khuddakapātha-atthakathā) [Pj I], PTS, London, 1959.

Madhyama-āgama [MA], TD1 (26). 
Majjhima-nikāya $[\mathrm{MN}]$, ed. V. Trenckner and R. Chalmers, PTS, London, 18881902.

Mahāvibhāṣāśāstra [Mv], TD 27 (1545), tr. Xuan-zang.

Manorathapūran̄ī (Ainguttara-nikāya commentary) [Mp], ed. M. Walleser and H. Kopp, PTS, London, 1924-57.

Milindapañha [Mil], ed. V. Trenckner, Williams and Norgate, London, 1880.

Mūlamadhyamakakārika de Nāgārjuna avec la Prasannapadā Commentaire de Chandrakīti [Mmd-p], ed. Louis de La Vallée Poussin, Petrograd, 1913.

Nettippakarana [Nett], ed. E. Hardy, PTS, London, 1961.

Nyāyānusāraśāstra [Na], TD 29 (1562), Saṅghabhadra, tr. Hiuan-tsang.

Papañcasūdan̄ (Majjhima-nikāya commentary) [Ps], ed. J. H. Woods, D. Kośambi and I. B. Horner, PTS, London, 1922-38.

Paramattha-Dīpan̄ V (Thera-gāthā-ațthakathā) [Th-a], ed. F. L. Woodward, PTS, London, 1959.

Paramattha-Dīpan̄ VI (Therī-gāthā-ațthakathā) [Th-a], ed. William Pruitt, PTS, Oxford, 1997.

Pațisambhidāmagga [Pațis] ed. A. C. Taylor, PTS, London, 1905-7.

Pețakopadesa [Pe], ed. A. Barua, PTS, London, 1982.

Prajñaptiśástra [Pra], TD26 (1538).

Prakaranapāda [Pk], TD 26 (1542).

Puggalapaññatti $[\mathrm{Pp}]$ and Puggalapaññati-ațthakathā, ed. R. Morris, G. Landsberg and C. A. F. Rhys Davids, PTS, London, 1972.

Saddhammapajjotik $\bar{a}$ [Sdp], the commentary on the Niddesa, Vol. III Culla-niddesa, ed. A. P. Buddhadatta, PTS, Oxford, 1989.

Samgītiparyāya [Sap], TD 26 (1536).

Samyukta-āgama [SA], TD2 (99).

Samyutta-nikāya [SN], ed. M. L. Feer, PTS, London, 1884-98.

Samantapāsādikā (Vinayapițaka commentary) [Sp], ed. J. Takakusu and M. Nagai, PTS, London, 1924- 47.

Sammohavinodan̄ (Vibhañga commentary) [Vibh-a], ed. A. P. Buddhadatta, PTS, London, 1923.

Sāratthappakāsin̄̄ (Samyutta-nikāya commentary) [Spk], ed. F. L. Woodward, PTS, London, 1929-37.

Sphuțārthā Abhidharmakośavyākhyā [Sa-w], ed. U. Wogihara, Tokyo, 1932.

Sumañgalavilāsin̄̄ (Dīgha-nikāya commentary) [Sv], ed. T. W. Rhys Davids, J. E. Carpenter and W. Stede, PTS, London, 1886-1932.

Suttanipāta [Sn], ed. D. Andersen and H. Smith, PTS, London, 1913.

Suttanipāta-atțakathā [Sn-a], ed. H. Smith, PTS, London, 1916-18.

Theragāthā and Therīgāthā [Th, Thī], ed. H. Oldenberg and R. Pischel, 2nd edn, PTS, London, 1966.

Theragāthā-ațthakathā [Th-a], ed. F. L. Woodward, PTS, Oxford, 1995.

Therīgāthā-atthakathā [Thī-a], ed. William Pruitt, PTS, Oxford, 1997.

Udāna [Ud], ed. P. Steinthal, PTS, London, 1992.

Vibhainga [Vibh] ed. C. A. F. Rhys Davids, PTS, London, 1904.

Vijñānakāya [Vk], TD 26 (1539).

Vinayapițaka [Vin] ed. H. Oldenberg, London, 1879-83.

Visuddhimagga [Vism] ed. H. C. Warren, revised D. Kosambi, Harvard, 1950.

Yamaka [Yam], ed. C. A. F. Rhys Davids, PTS, London, 1911, 1913. 


\section{SECONDARY SOURCES}

Adikaram, E. W. (1946) The Early History of Buddhism in Ceylon. Colombo.

Akanuma, Chizen (1929) The Comparative Catalogue of Chinese Ägamas and Päli Nikāyas. Nagoya.

Aung, S. Z. and Rhys Davids, C. A. F. (1915) Points of Controversy. London.

Bareau, André (1951) L'Absolu: en philosophie bouddhique, evolution de la notion d'asamskrta. Paris.

Bareau, André (1954) Les premiers conciles bouddhiques. Paris.

Bareau, André (1955) Les sectes bouddhiques du petit véhicule. Paris.

Bareau, André (1966) Le bouddhisme indien, les religions de l'Inde. Paris.

Bronkhorst, Johannes (1985) 'Dharma and Abhidharma'. BSOAS, pp. 305-20.

Bronkhorst, Johannes (1986) The Two Traditions of Meditation in Ancient India. Stuttgart.

Bodhi, Bhikkhu (1993) A Comprehensive Manual of Abhidhamma. Kandy.

Childers, Robert Ceasar (1872) A Dictionary of the Pali Language. London.

Collins, S. (1982) Selfless Persons: Imagery and Thought in Theravāda Buddhism. Cambridge.

Collins, S. (1998) Nirvana and Other Buddhist Felicities. Cambridge.

Cone, Margaret (2001) A Dictionary of Pāli, Part I. Oxford.

Conze, E. (1962) Buddhist Thought in India. London.

Cousins, L. S. (1983) 'Nibbāna and Abhidamma'. Buddhist Studies Review, 1(2), pp. $95-109$.

Cousins, L. S. (1999) 'Review of How Buddhism Began by Richard F. Gombrich'. BSOAS, pp. 372-3.

Cox, Collet (1995) Disputed Dharmas: Early Buddhist Theories on Existence. An Annotated Translation of the Section on Factors Dissociated from Thought from Sañghabhadra's Nyāyānusāra. Tokyo.

Cox, Collet (1998) Sarvāstivāda Buddhist Scholasticism. Brill.

Dutt, Nalinaksha (1960) Early Monastic Buddhism. Calcutta.

Edgerton, Franklin (1952) The Bhagavad Gittā. Oxford.

Frauwallner, Erich (1995) Studies in Abhidharma Literature and the Origins of Buddhist Philosophical Systems, tr. Sophie Francis Kidd. New York.

Gombrich, Richard F. (1988) Theravāda Buddhism: A Social History from Ancient Benares to Modern Colombo. London.

Gombrich, Richard F. (1996) How Buddhism Began. London.

Guenther, Herbert V. (1974) Philosophy and Psychology in the Abhidharma. Berkeley, CA.

Hamilton, S. (1996) Identity and Experience: The Constitution of the Human Being According to Early Buddhism. London.

Hamilton, S. (2000) Early Buddhism: A New Approach, The I of the Beholder. London. Hidenori, Kitagawa (1966) 'On "upādhi"'. JIBS, pp. 430-6.

Harvey, Peter (1990) An Introduction to Buddhism: Teachings, History and Practices. Cambridge.

Harvey, Peter (1995) The Selfless Mind. Surrey.

Harvey, Peter (2000) An Introduction to Buddhist Ethics. Cambridge.

Horner, Isalin Blew (1934) 'The four ways and the four fruits in Pāli Buddhism'. Indian Historical Quarterly, pp. 785-96. 
Horner, Isalin Blew (1936) The Early Buddhist Theory of Man Perfected. New Delhi (republished 1979).

Huzita, Koudazu (1988) 'Nirvana in the early Buddhism, nibbāna and Paranibbāna'. JIBS, pp. 1-2.

Jaini, Padmanabh S. (1959a) 'The development of the theory of the Viprayuktasaṃskāras'. BSOAS, pp. 531-47.

Jaini, Padmanabh S. (1959b) 'The Sautrāntika theory of Bīja'. BSOAS, pp. 236-49.

Jayatilleke, K. N. (1980) Early Buddhist Theory of Knowledge. Delhi.

Kachiyama, Yuichi (1988) 'History of Indian Buddhist thought'. Indian Buddhism, pp. 3-57.

Kalupahana, David J. (1975) Causality: The Central Philosophy of Buddhism. Honolulu.

Kalupahana, David J. (1992) A History of Buddhist Philosophy. Honolulu.

Karunadasa, Y. (1967) Buddhist Analysis of Matter. Colombo.

Katz, Nathan (1982) Buddhist Images of Human Perfection. Delhi.

Lamotte, Étienne (1936) Le traité de l'acte de Vasubandhu Karmasiddhiprakarana. Bruges.

Lamotte, Étienne (1973) La somme du grand véhicule d'Asanga. Louvain-la-Neuve.

Lamotte, Étienne (1988) History of Indian Buddhism, tr. Sara Webb-Boin. Louvainla-Neuve.

La Vallée Poussin, Louis de (1923) Abhidharmakośabhāṣyam, tr. Leo M. Pruden (1988). Berkeley, CA.

La Vallée Poussin, Louis de (1925) Nirvāna. Paris.

La Vallée Poussin, Louis de (1928) Vijñaptimātratāsiddhi: la Siddhi de Hiuan Tsang. Paris.

La Vallée Poussin, Louis de (1930) 'Documents d'Abhidharma'. BEFEO, 30, pp. 128, 247-98.

Law, B. C. (1940) The Debates Commentary. London.

Lévi, S. (1937) La transmigration des âmes dan les croyances hindoues: mémorial S. Lévi. Paris.

Lovejoy, Arthur Oncken (1898) 'The Buddhistic technical terms upādāna and upādisesa'. JAOS, 14, pp. 127-36.

Masefield, Peter (1979) 'The nibbāna-Parinibbāna controversy'. Religion, 9, pp. 21530.

Masuda, J. (1925) Origin and Doctrines of Early Indian Buddhist Schools. London.

Maung Tin (1958) The Expositor (Atthasālinī). New York.

Murti, T. R. V. (1970) The Central Philosophy of Buddhism. London.

Nārada, U. (1977) Discourse on Elements (Dhātu-kathā). London.

Norman, K. R. (1992) The Group of Discourses (Sutta-nipāta), Volume 2. Oxford.

Norman, K. R. (1993) 'Mistaken ideas about nibbāna'. Buddhist Forum, 3, pp. 21125.

Ñyānamolị, Bhikkhu (1960) The Minor Readings. London.

Ñyāṇamoḷi, Bhikkhu (1962) The Guide. London.

Ñyānamoli, Bhikkhu (1976) The Path of Purification. Colombo.

Ñyāṇamoḷi, Bhikkhu (1992) The Dispeller of Delusion. London.

Oldenberg, Hermann (1882) Buddha: His Life, His Doctrine, His Order, tr. William Hoey (1992). New Delhi.

Olivelle, Patrick (1996) Upaniṣads. Oxford. 
Pasadika, Bhikkhu (1986) Kanonische Zitate im Abhidharmakośabhāṣya des Vasubandhu. Göttingen.

Pe Maung Tin (1922) The Expositor. London.

Popper, Karl (1995) The Open Society and Its Enemies. London.

Rahula, Walpola (1967) What the Buddha Taught. Bedford.

Rhys Davids, C. A. F. (1974) Buddhist Psychological Ethics. London.

Rhys Davids, C. A. F. (1993) The Books of the Kindred Sayings. Oxford.

Sakurabe, Hajime (1969) Kusharon no kenkyū. Kyoto.

Sanderson, A. (1994) 'The Sarvāstivāda and its critics: Anātmavāda and the theory of karma'. In Buddhism into the Year 2000. Bangkok.

Salomon, Richard (1999) Ancient Buddhist Scrolls from Gandhāra. London.

Schrader, F. Otto (1905) 'On the problem of nirvāṇa'. JPTS, pp. 157-70.

Schumann, H. W. (1989) The Historical Buddha, tr. M. O’C. Walshe. London.

Somaratne, G. A. (1999) 'Intermediate existence and the higher fetters'. JPTS, pp. 121-54.

Stcherbatsky, Th. (1923) The Central Conception of Buddhism and the Meaning of the Word 'Dharma'. London.

Stcherbatsky, Th. (1968) The Conception of Buddhist Nirvāna. Delhi.

Thanissaro, Bhikkhu (1993) The Mind Like Fire Unbound. Barre, MA.

Thomas, Edward J. (1927) The Life of Buddha as Legend and History. London.

Thomas, Edward J. (1933) The History of Buddhist Thought. London.

Thomas, Edward J. (1947) 'Nirvāṇa and Parinirvāṇa'. India Antiqua, pp. 294-5.

Warder, A. K. (1970) Indian Buddhism. Delhi.

Welbon, Guy Richard (1968) The Buddhist Nirvāna and Its Western Interpreters. Chicago, IL.

Zaehner, R. C. (1973) The Bhagavad-Gìtā with a Commentary Based on the Original Sources. Oxford. 


\section{INDEX}

Abhidharmakośabhāṣya 1, 3, 5, 18, 28, 39, 40, $52,66,68,71,73,77,79,80,82,87-98,108$, 121

ābhiprāyika 1, 18, 108

absorption of extinction see nirodhasamāpatti $\bar{a} k \bar{a} s a$ 38, 68-70, 122

$\bar{a} k \bar{a} s$ a see ākāsa

ākșepakukarman 79, 82, 89, 90, 97, 118, 119

ālayavijñ̄ana 96, 111

anādikālika-prakrtiśsuddha-nirvāna 4

anāgāmin 14-16, 23-31, 33, 35, 106-7

anātman 22, 60, 85

aก̃̃̄a $14,20,28-30$

anulakșana 102

anupadhiśeșanirvāna see anupādisesanibbāna

anupādisesa 14, 18, 25, 29, 117

anupādisesanibbāna 3, 10, 13-15, 20-3, 28-32, $36-8,42-5,47-50,57,65,67,74-85,91-2$, $97,105-6,110,116-18,120-1$

Anuruddha 3, 5, 63-4, 77, 97-104, 108, 110, 124

anuśaya 91, 92, 93, 94, 95, 96, 97, 99, 105, 110 appațisañkhānirodha see apratisaṃkhyānirodha apperception see samjīna

apratișthita-nirvāna 4

apratisamkhyānirodha 38, 41-2, 72-3

arahant 10, 14-15, 19-35, 42-3, 46, 49, 67, 81, $83,106,115-20$

ariyapuggala 14, 16, 23-27, 29-32, 34

asainkhata 5, 11, 37-8, 42, 48, 64, 66-8, 70, 72,

$74,88,100,103,115,117,122,124$

asamskrta see asañkhata

āsava 3, 11, 17, 26-32, 51, 52, 105

āśraya 93, 96-9, 119, 123

ātman $10,22,49,54-6,60,85$

àvedha $14-15,89-90,97,105,110$

āyu 42-5, 47-8, 78-85, 90, 97, 105, 110, $117-19,120$

Bareau, André 31, 38, 68

basis see āśraya

Bhagavad-Gītā 10

bīja see büjabhāva bïjabhāva 92-4, 96-7, 99, 121

birth body see janmakāya

brahmanirvāna 10

Brahmāyu 34

Bṛhadāranyaka Upanișad 33, 59, 60

Bronkhorst, Johannes 22

Buddhaghosa 3-4, 12, 38, 45-8, 51, 74

Candrakīrti 49, 98, 100

cankers see āsava

cessation of defilements see kilesa-parinibbāna cessation of aggregates see khandha-parinibbāna cessation see nirodha

cetanā 19, 21, 22, 23, 53, 71, 121

Chāndogya Upaniṣad 33

cittaviprayuktasaṃskāra 78, 80, 81, 84, 87, 90, 93, 101

classification 36, 37, 38, 39, 64, 65, 66, 67

Collins, Steven 12, 57, 61

consciousness see vijñāna

contact see sparśa

contingent see ābhiprāyika

Cousins, L. S. 2, 37, 66, 68

Cox, Collet 39, 87

Dārșțāntikas 72, 86-7

dhammānusārin 24, 25, 27, 29

Dharmaguptaka 31

disjunction see visamyoga

disputant see vitandavādin

dravya 40, 42, 46, 69, 72-3, 77, 85-9, 91, 96,

$101,104-5,109,110,117,122$

dravyāntara 88, 90, 101, 124, 125

eighteen dhātu 64-5, 70

eighteen elements see eighteen dhātu

enlightenment $2-3,10-16,18,26,32,52-3,65$, $67,75,92,106$

entity see dravya

extinction through knowledge see

pratisamkhyānirodha

extinction without knowledge see

apratisamkhyānirodha 


\section{IN D E X}

faculty see indriya

fetters see samyojana

final liberation $10,11,14,23,26,46-8,67,92$, 104

final nirvana see final liberation

fire image see image of a fire

Fire Sermon 18

five aggregates see pañcaskandha

five faculties see pañcindriya

five spiritual faculties 27,28

four kinds of upādāna 16, 18, 26

four noble persons see ariyapuggala

Frauwallner, E. 39

\section{Gandhārī 18}

Gombrich, Richard F. 1, 2, 3, 11, 16, 18, 21, 53

gotrabhü 24, 25, 27, 29, 116

Hamilton, Sue, 22

Harvey, Peter 5, 28, 50

hetuvāda 44

homogeneous character see sabhāgatā

homogeneous character of the group see nikāyasabhāga

Horner, I. B. 29

Huzita, Koudazu 15, 21

image of a fire $3,19,56-63,103,106-8,110$

indriya $21,22-8,30,37,45,56,69,80,83,84$, $88,118-20$

intention see cetanā

intrinsic nature see svabhāva

Jaini, Padmanabh S. 92

Jainism 10, 23, 34

janmakāya 35, 47, 81-2, 107

janmakāyopadhi 35, 118, 119

janman 82, 91, 97-8, 105, 110, 121

Jayatilleke 55, 88

j̄ivitendriya see jivitindriya

jovitindriya 45, 47-8, 78-90, 105, 110, 117-19

Jñānaprasthāna 4, 28, 35-9, 42-5, 48, 71, 77-9, $82-4,87,90,105,110,116-18$

\section{Kalupahana 55}

karman 1, 12, 23, 71, 82, 94, 95, 110

Kāśmīra Sarvāstivādins 72

Kāśyapīya 31

Kathāvatthu 38, 68-70, 74

khandha-parinibbāna 14, 45, 47, 50, 64, 74, 101, 105,124

kilesa-parinibbāna 11, 14, 45, 47, 50, 74-5, 99, $104-5,115$

kleśanirodha see kilesa-parinibbāna

Kui-ji 86

La Vallée Poussin, Louis de 4, 5, 9, 15-16, 23

lāksanika 1, 108

Lamotte, Étienne 31, 60 lamp 45, 58, 63, 64, 98, 101, 102, 104, 108, 110, 124,125

latent defilements see anuśaya

liberation 11, 15, 23, 31, 33, 101, 103, 108, 124

life faculty see jīvitindriya

literalism 2, 106

Lovejoy, A. O. 14, 28

Mahāsāninghikas 31-2, 72

Mahāvibhāsāśästra 1, 5, 11-12, 35, 42, 44-5, 47-8, 66, 70-3, 77-88, 90, 107, 110

Masefield, Peter 4, 14, 22, 28, 45-6

mātrkā 36

mental body see nāmakāya

metaphor 1-5, 10-21, 35-7, 50-1, 55, 57,

$59-60,63,74,81,90,105-8,110$

methodology 5, 51-8, 60, 71-2, 107

methodological essentialism 53

methodological nominalism 53

momentariness $77,91-2,108$

theory of $5,44,48,70,72,74,99,109$

momentum see āvedha

Murti, T. R. V. 55

nāmakāya 61-2

nibbāna 12, 21-2, 26, 37, 38, 39, 63, 66, 74-5, $109,115,116$

nikāyasabhāga 79, 80, 81, 82, 83, 84, 85, 86, 87, $88,89,90,97,105,110,117,119$

niranupadhiśeșa see anupādisesa

nirodha 38, 41-3, 48, 83-5, 98, 62, 73, 76, 99,

$101,103,105,110,115-16,117-24$

nirodhasamāpatti 38, 83, 96, 120

nirupadhiśeșanirvāṇa see anupādisesanibbāna

nirvana with a remainder of clinging see sopādisesanibbāna

nirvana without a remainder of clinging see anupādisesanibbāna

nirvāna see nibbāna

non-returner see anāgāmin

Norman, K. R. 9, 17, 29

Ñyāṇamoli 9, 19-20, 25, 46-7, 63

Nyāyānusāraśāstra 3, 5, 73, 77, 97-101, 104, 124

object see visaya

Oldenberg, Hermann 14, 28

once-returner see sakadāgāmin

ordinary person see puthujjana

Pali abhidhamma 4, 36-8, 42, 64, 66-8

pañcaskandha 3, 10, 19-22, 37, 39-40, 44-5,

$49,57,64-7,81,85,90,101,103,105-7,110$, 124

pañcavastuka 39, 40, 66

pañcindriya 19-21, 37, 42-5, 48, 54, 79, 82-4,

96, 105, 117-21

paramātman 50

paryavasthāna $92-3,96$

paścādabhāva 46, 77, 91, 110

pațisañkhānirodha see pratisamkhyānirodha 


\section{IN D E X}

pāțiyekka 62, 74-7, 97, 99, 100, 102-5, 109

perfect knowledge see añ̃̄a

Popper, Karl 53

prāpti 16, 17, 40-2, 73, 77, 85-6, 91, 93-4, 99-100, 109, 119, 123

pratisaṃkhyānirodha $38,40-2,70,72-3,77,78$, $85,91,105,109,110,116$

prthagjana see puthujjana

puthujjana 24-5, 85

real existent see dravya

Rg-Veda 34

sabhāgatā 45, 48, 82, 88, 89, 110, 118, 119

saddhānusārin 24-5, 27, 29

saint, sainthood see arahant

sakadāgāmin 23, 24, 25, 26, 27

Salomon, Richard 18

samiñ̄a 21-2, 37, 65-7, 121

Sammohavinodanī 5, 12, 75, 76, 97, 103, 105

sammukhībhāva 92

saṃtānaparin̄āmaviśeșa 94-7

samyojana 3, 25-35, 42-3, 48, 83-5, 105, 117-20

Sanghabhadra 3, 5, 87, 98, 101-4, 108

Sarvāstivāda 1, 3, 5, 13, 31, 32, 36, 39-48, $63-4,66,69-73,75,77-85,87,89-102,105$, $107-11$

Śatapatha Brāhmana 34

Saupadhiśeșa see sopādisesa

Sautrāntikas 3, 5, 20, 46, 48, 63, 66, 71-3, 77, $86-105,108,110-11,121-5$

Schrader, F. Otto 5, 50, 58, 59, 103

seed see bījabhāva

self see àtman

series of aggregates see skandhasamtāna

seven fruit 30

seven noble persons $23,24,25,28$

skandhasamitāna 40-1, 44, 63, 73, 77, 85-6, 89-100, 108-9

sopadhiśeșanirvāna see sopādisesanibbāna

sopādisesa 14, 25, 29, 46, 79, 81-2, 87, 89, 90, 106-7, 110, 116

sopādisesanibbāna $3,10-15,18,20-3,28-32$, $36-8,42-8,50,57,59-64,67,74-8,81-6$, $91,97,104-10,116-21,125$

sotāpanna $23-7,32,34$

soul see ātman

space see ākāsa

sparśa $19-22,54$

special transformation of a series see samtānaparināmaviśesa

Sphuțārtha Abhidharmakośavyākhyā 18, 88, 89, 91,97

state of being seed see bījabhāva

stream-enterer see sotāpanna

support see āśraya
Suttanipāta 16, 28, 30, 48, 60, 61

svabhāva 39-41, 47, 69, 73, 89-92, 97, 101-3, $108,115,123,125$

Śvetāśvatara Upaniṣad 59, 60

tam āgamma 75, 76, 109

ten samyojana $25-8$

Theravāda $1,3-5,11-15,20-5,29,32,37-8$, $45-7,51,60-71,74-7,83,92,97,100$, $103-5,109,110$

thinking according to the cause see yoniso manasikāra

three unconditioned things 38, 40, 109

Thomas, E. J. 10, 16

triple fire 2-4, 10-13, 19-21, 42, 57, 65, 105, 109-10

twelve āyatana 65,70

two nirvana elements $4,15-16,20,28,31-2$, $42,45-8,78,116-17,120$

two nirvana theory $3-5,14,16,20,29,30-2$, $35-8,42-8,64,77-84,86-7,90,104,106-8$, $110-11,116,120$

unconditioned see asankhata upādāna 16, 17-19, 20, 28, 67

upādāna-kkhandhā 19

upadhi see upādi

upādi 3-4, 14-18, 20-3, 28-30, 35, 47, 81, 90, $105-7,110$

Vaibhāșikas 72, 75, 79-82, 84-102, 104, 107-8, $111,121-4$

Vaiśeșikas 88

vastu 98,123

Vasubandhu 1, 3, 66, 87-9, 91, 93-8, 100, 111

Vātsīputrīyas 70

vedanā 21-2, 37, 54, 56, 58, 65, 67, 91, 121, 123

Vibhainga 5, 37, 67-9, 75, 103

Vibhajyavāda $13,32,64,70-3,83$

vijñāna $12,19,21-2,37,41,45-6,53-4,61$, $65-7,69-70,79,121-2$

vișaya $17,19-22,37,41-2,45,54,121-2$

visamyoga 40-2, 73, 77, 85-6, 91, 98, 100, 105, $116,120-1$

vitandavādin $63,67,75,109,115-16$

vital organ see jivitindriya

vitality see $\bar{a} y u$

Visuddhimagga 3, 5, 12, 24, 38, 40, 45, 47-8, $74-5$

volition see cetanā

Warder, A. K. 47, 53

with a remainder of clinging see sopādisesa without a remainder of clinging see anupādisesa

Yaśomitra 18, 88, 91

yoniso manasikāra 5, 51-6, 58, 60, 107-8 